\title{
ASCORBATE BIOSYNTHESIS AND \\ ITS PHYSIOLOGICAL ROLES \\ IN THE GREEN ALGA CHLAMYDOMONAS REINHARDTII
}

\author{
PhD Thesis
}

\section{André Manuel Vidal Meireles}

Supervisor: Dr. Szilvia Zita Tóth

Biological Research Centre of the Hungarian Academy of Sciences

Institute of Plant Biology

Laboratory of Molecular Photobioenergetics

University of Szeged

Doctoral School of Biology

Szeged, 2018 



\section{Table of Contents}

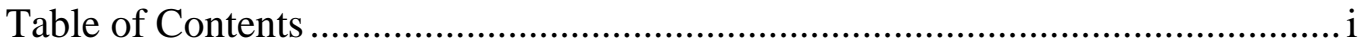

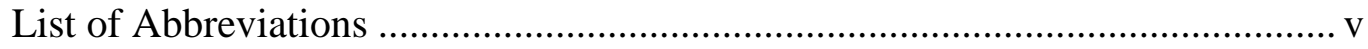

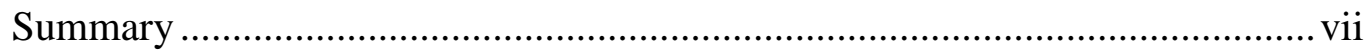

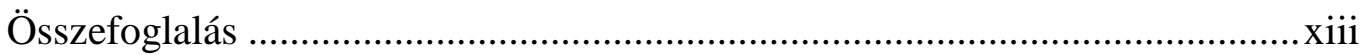

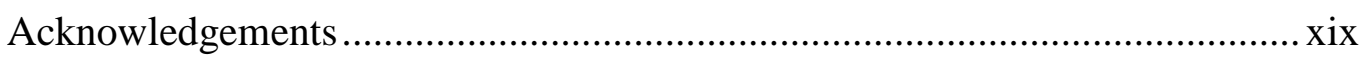

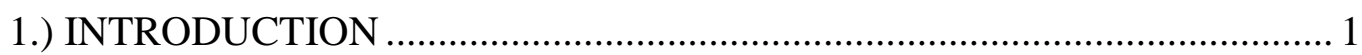

1.1) Green algae and their ecological importance ............................................ 1

1.1.1) The green alga Chlamydomonas reinhardtii as a model organism..... 1

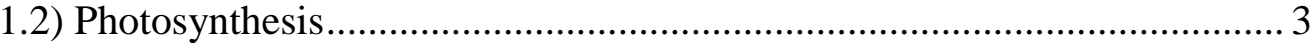

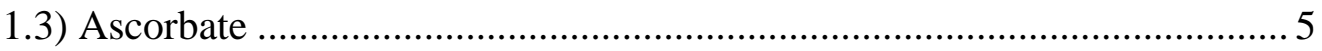

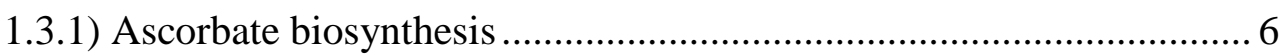

1.3.2) The role of Asc under environmental stress conditions ...................... 7

1.3.2) Ascorbate regeneration..................................................................... 8

1.4) Hydrogen photoproduction in Chlamydomonas reinhardtii....................... 9

1.4.1) Ascorbate modulates the initiation of the $\mathrm{H}_{2}$ production in $C$.

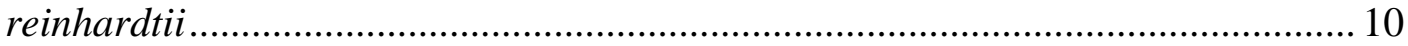

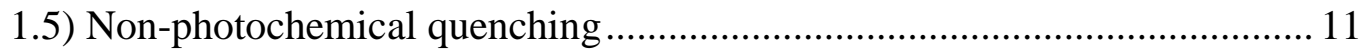

1.5.1) Energy-dependent quenching (qE) ................................................ 12

1.5.2) Zeaxanthin-dependent quenching (qZ) ............................................ 13

1.5.3) Photoinhibitory quenching (qI) ..................................................... 14

1.5.4) State transition-dependent quenching (qT) ....................................... 15

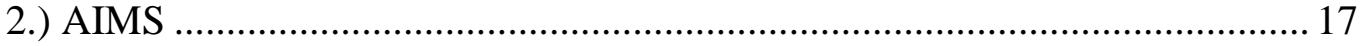

3.) MATERIALS AND METHODS ……………………........................ 19

3.1) Regulation of Asc biosynthesis and its physiological importance in $C$.

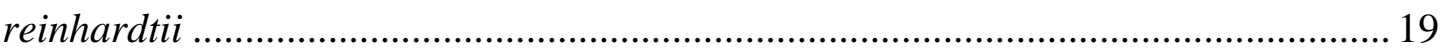

3.1.1) Algal strains and growth conditions ................................................ 19

3.1.2) amiRNA design and transformation ............................................... 19

3.1.3) Analysis of gene expressions ......................................................... 20

3.1.4) Determination of cell size and cell density ...................................... 21

3.1.5) Light and chemical treatments ....................................................... 21

3.1.6) Ascorbate content determination by HPLC....................................... 22 
3.1.7) Metabolite profiling using GC-MS .............................................23

3.1.8) Electron transport measurements ...............................................24

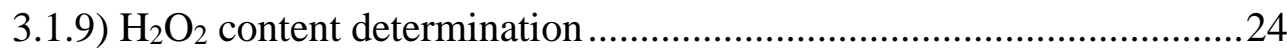

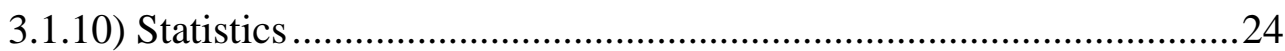

3.2) Determination of the role of Asc in the inactivation of PSII during sulphur deprivation-induced $\mathrm{H}_{2}$ production in $C$. reinhardtii ..............................................25

3.2.1) Algal growth conditions and sulphur deprivation...........................25

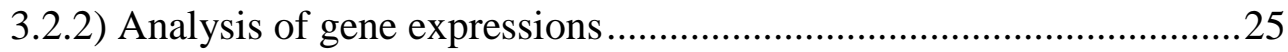

3.2.3) Western blot analysis and protein content determination.................26

3.2.4) Determination of cell size and cell density .....................................26

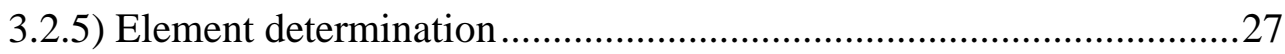

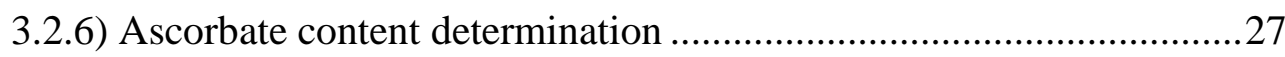

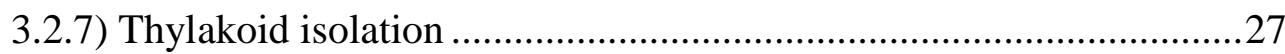

3.2.8) Measurement of electron transport activity ..................................27

3.2.9) Thermoluminescence measurements ...........................................28

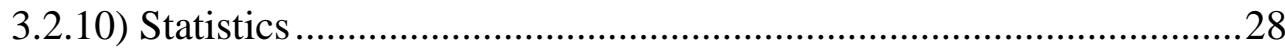

3.3) Determination of the role of Asc in the induction of NPQ.....................29

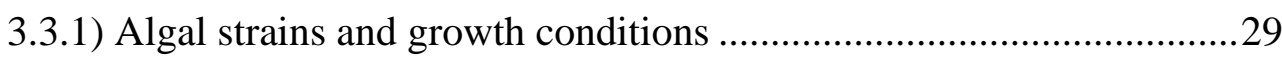

3.3.2) DNA Isolation and PCR ............................................................29

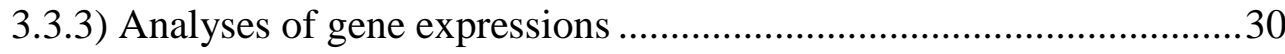

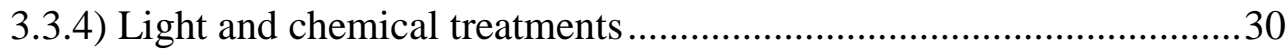

3.3.5) Electron transport measurements......................................................30

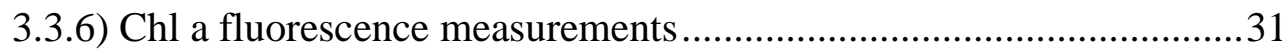

3.3.8) Low-temperature fluorescence emission spectra measurements .......31

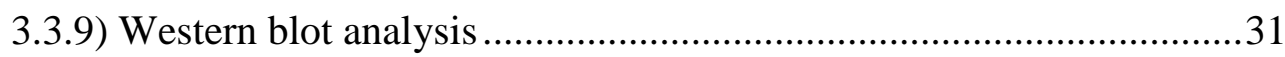

3.3.10) Determination of cell size and cell density ....................................32

3.3.11) Ascorbate content determination ..................................................32

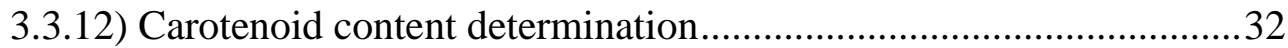

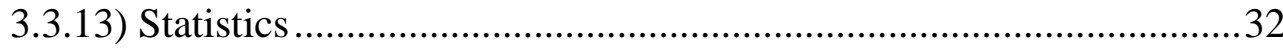

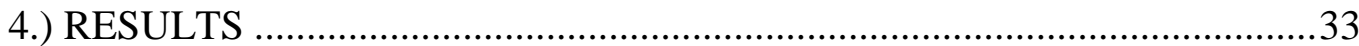

4.1) Regulation of Asc biosynthesis and its physiological importance in $C$. reinhardtii

4.1.1) Generation of Asc-deficient $C$. reinhardtii strains using an amiRNA approach 
4.1.2) The effects of $\mathrm{H}_{2} \mathrm{O}_{2}$ and high light stress on the Asc content and VTC2 expression

4.1.3) The physiological effects of Asc deficiency in C. reinhardtii 40

4.1.4) The effects of Asc-deficiency on photosynthetic electron transport. 43

4.1.5) Dependence of the Asc biosynthesis on the photosynthetic electron transport chain ..... 46

4.1.6) Asc biosynthesis upon dark-to-light transition and during the circadian cycle 50

4.2) Determination of the role of Asc in the inactivation of PSII during sulphur deprivation-induced $\mathrm{H}_{2}$ production in $C$. reinhardtii .55

4.2.1) The degradation of photosynthetic complexes during sulphur deprivation .55

4.2.2) GDP-L-galactose phosphorylase is induced upon sulphur deprivation 58

4.2.3) The decline of PSII activity may involve donor-side induced photoinhibition 60

4.3) Determination of the role of Asc in the induction of NPQ 64

4.3.1) Identification and preliminary characterization of the C. reinhardtii VTC2 insertion mutant 64

4.3.2) The effects of Asc deficiency on NPQ in cultures grown under photomixotrophic conditions at normal light

4.3.3) The effects of Asc deficiency on NPQ in cultures grown under photoautotrophic conditions at normal light .76

4.3.4) The effects of Asc deficiency on NPQ in cultures grown under photoautotrophic conditions at high light 81

5.) DISCUSSION .87

5.1) Regulation of the Asc biosynthesis and its physiological importance in $C$. reinhardtii .87

5.1.1) Physiological consequences of Asc deficiency in C. reinhardtii..... 88

5.1.2) Regulation of Asc biosynthesis in C. reinhardtii vs. higher plants... 88

5.2) Determination of the role of Asc in the inactivation of PSII during sulphur deprivation-induced $\mathrm{H}_{2}$ production in $C$. reinhardtii. .92

5.2.1) The degradation of photosynthetic complexes during sulphur deprivation .92 
5.2.2) GDP-L-galactose phosphorylase is induced upon sulphur deprivation

.93

5.2.3) The decline of PSII activity may involve donor-side induced photoinhibition .94

5.3) Determination of the role of Asc in the induction of NPQ .95

5.3.1) The effects of Asc deficiency on NPQ in cultures grown under photomixotrophic conditions at normal light. .95

5.3.2) The effects of Asc deficiency on NPQ in cultures grown under photoautotrophic conditions at normal light .96

5.3.3) The effects of Asc deficiency on NPQ in cultures grown under

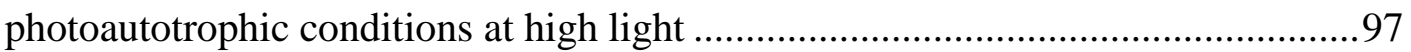

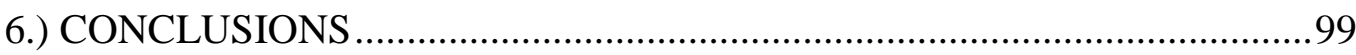

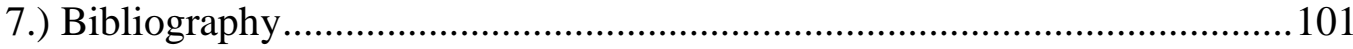

List of Publications ........................................................................................ A-1

Communications at International Conferences ............................................... A-3

Awards and fellowships .............................................................................. A-5 


\section{List of Abbreviations}

amiRNA Artificial microRNA

APX Ascorbate peroxidase

ARG7 Argininosuccinate lyase

Asc Ascorbate

CBB Calvin-Benson-Bassham

CDS Coding region

Chl Chlorophyll

CrVDE Chlamydomonas reinhardtii violaxanthin deepoxidase

DCMU 3-(3',4'-dichlorophenyl)-1,1-dimethylurea

DHA Dehydroascorbate

DHAR Dehydroascorbate reductase

DPC Diphenylcarbazide

EV Empty vector

GPXs Glutathione peroxidases

$\mathrm{H}_{2} \mathrm{O}_{2} \quad$ Hydrogen peroxide

HSM High salt minimal

LHC Light-harvesting complex

LM Lincomycin

MDA Monodehydroascorbate

MDAR Monodehydroascorbate reductase

MV Methylviologen

NPQ Nonphotochemical quenching

OEC Oxygen-evolving complex

PS Photosystem

$\mathrm{qE} \quad$ Energy-dependent quenching

qI Photoinhibitory quenching

qT State transition-dependent quenching

qZ Zeaxanthin-dependent quenching

RB Rose Bengal

ROS Reactive oxygen species

TAP Tris-acetate-phosphate 
uORF

Upstream open reading frame

VDE

Violaxanthin deepoxidase

${ }^{1} \mathrm{O}_{2}$

Singlet oxygen

$\Delta \mathrm{pH}$

Proton gradient 


\section{Summary}

\section{1.) Introduction}

C. reinhardtii has emerged as an excellent model system to study both photosynthesis and biogenesis of the chloroplast, mostly due to its capability for heterotrophic growth and using acetate as a carbon source so that even mutants deficient in photosynthesis are viable (Harris, 2001). Another advantage of using Chlamydomonas as a model system is that it represents the only photosynthetic organism that is suitable for transformation of all genetic compartments: nucleus, chloroplast, and mitochondria (Nickelsen, 2005). Recent development in genetic tools (amiRNA and CRISPR/Cpf1 techniques) make it also an ideal model organism.

Ascorbate (Asc) is of vital importance to the cellular functions of both animals and plants. It is an essential scavenger of reactive oxygen species (ROS) including singlet oxygen and superoxide and it is also a cofactor of several 2-oxoacid-dependent dioxygenase enzymes, which catalyze a large number of physiological processes in the cell. In higher plants, besides its role as an antioxidant, Asc also participates in cellular development and synthesis of the cell wall. Asc also modulates the synthesis of several signaling molecules such as abscisic acid, gibberellins, ethylene and salicylic acid. It also influences anthocyanin accumulation during high light acclimation; it is involved in the regulation of stomatal movement and also modulates the expression of specific sets of photosynthesis and defense genes via poorly understood mechanisms. Asc also contributes to the non-photochemical quenching in higher plants because it is a cofactor of violaxanthin deepoxidase.

In higher plants, the main Asc biosynthesis pathway is the L-galactose pathway, also called the "Smirnoff-Wheeler" pathway; this is the main contributor of Asc synthesis in higher plants, shown by the observation that mutants affected in the key enzymes of this pathway are unable to compensate for the loss of the Asc biosynthetic capacity. The rate of Asc biosynthesis is largely determined by the expression level of $V T C 2$, encoding GDP-L-galactose phosphorylase, as demonstrated by the vtc2-1 Arabidopsis mutant which contains approx. 80\% less Asc relative to its control strain (Conklin et al., 2000; Müller-Moulé et al., 2002, 2004).

The genome of the model green alga $C$. reinhardtii encodes all the enzymes of the Smirnoff-Wheeler Asc biosynthesis pathway; based on gene expression analysis, it 
was suggested that the algal GDP-L-galactose phosphorylase is a highly regulated enzyme, similarly to higher plants (Urzica et al., 2012). Overall, Asc biosynthesis and its regulation are poorly studied in non-vascular plants and in green algae, organisms that possess low Asc contents (Gest et al., 2013; Wheeler et al., 2015).

We showed recently that Asc may have an important modulatory effect on the photobiological $\mathrm{H}_{2}$ production of $C$. reinhardtii (Nagy et al., 2016). The oxidation of water, primary source of reducing equivalents for photosynthesis, is carried out by the oxygen evolving complex (OEC) of PSII. We have shown that upon sulphur deprivation, Asc accumulates dramatically and it inactivates the OEC due to its reducing property. Even though Asc can donate electrons to PSII, that happens at a slow rate, donor-side induced photoinhibition takes place, causing a loss of the charge separation activity of PSII. These events lead to the establishment of anaerobiosis, which is essential for $\mathrm{H}_{2}$ production (Nagy et al., 2016). However, the exact mechanism by which Asc may inactivate PSII during sulphur deprivation-induced $\mathrm{H}_{2}$ production in C. reinhardtii remained unclear.

For photosynthetic organisms, light absorption is required for growth, but too much light can be harmful. The photo-protective mechanisms responsible for dissipating the excess energy as heat are collectively called non-photochemical quenching (NPQ). NPQ includes short-term responses to rapid fluctuations in light, as well as responses that occur over longer periods allowing for acclimation to high light exposure. One of the key components of NPQ involves the conversion of violaxanthin to zeaxanthin, which is catalyzed by the enzyme violaxanthin de-epoxidase (VDE). The VDE enzyme of $C$. reinhardtii (CrVDE) differs from the VDE enzyme found in plants and in most algae ( $\mathrm{Li}$ et al., 2016b), and it was unknown whether Asc is required as a co-factor for the algal-type VDE, and thereby to qZ induction.

\section{2.) Aims}

- Studying the regulation of Asc biosynthesis and its physiological importance in C. reinhardtii

- Determination of the role of Asc in the inactivation of PSII during sulphur deprivation-induced $\mathrm{H}_{2}$ production in C. reinhardtii

- Determination of whether Asc is required as a co-factor of CrVDE and investigating the role of Asc in NPQ induction. 


\section{3.) Applied methods and techniques}

- $\quad$ amiRNA;

- $\quad$ C. reinhardtii nuclear transformation;

- $\quad$ cDNA synthesis;

- $\quad$ Chl $a$ fluorescence;

- $\quad$ DNA and RNA isolation;

- GC-MS;

- HPLC;

- ICP-OES;

- $\quad$ Northern blot;

- $\quad$ PCR and qRT-PCR;

- $\quad$ Protein isolation;

- Thermoluminescence;

- Thylakoid isolation.

- Western blot;

\section{4.) Summary of findings}

Ascorbate biosynthesis and its regulation are poorly studied in non-vascular plants, even though it was known that the genome of the model green alga $C$. reinhardtii encodes all the enzymes of the Smirnoff-Wheeler Asc biosynthesis pathway, no direct evidence for its physiological function was available. In addition to demonstrate the importance of the VTC2 gene in Asc biosynthesis, in this thesis it was also demonstrated that the regulation of Asc biosynthesis has evolved markedly different mechanisms in $C$. reinhardtii than in higher plants:

- The expression of the VTC2 gene of C. reinhardtii is not directly influenced by the photosynthetic electron transport chain;

- In contrast to higher plants, VTC2 transcript abundance is not under circadian control in C. reinhardtii;

- Upon oxidative stress, VTC2 is strongly upregulated, allowing a very rapid Asc accumulation;

- There is no negative feedback regulation in the physiological Asc concentration range. 
This set of results was published in Vidal-Meireles et al (2017) New Phytologist 214: 668-681, doi: 10.1111/nph.14425.

Under stress conditions, such as sulphur deprivation, C. reinhardtii can increase their Asc concentration to levels that may lead to inactivation of the OEC, which may lead to the establishment of hypoxia, followed by the initiation of $\mathrm{H}_{2}$ production. Based on these earlier results (Nagy et al., 2016), we aimed to better understand the role of Asc in these processes and we found that:

- The sulphur content decreases only moderately upon transferring the cells to sulphur-free media, which is unlikely to be the main cause for substantial loss of $\mathrm{PsbA}$ as it is generally assumed;

- $\quad$ PsbA has a discernible turnover during sulphur-deprivation;

- The transcript abundance of the VTC2 gene increases upon sulphur deprivation, which leads to Asc accumulation up to the $\mathrm{mM}$ range;

- $\quad$ The decline of PSII activity may be caused by donor-side induced photoinhibition exerted by the strong Asc accumulation.

These results were published in Nagy et al. (2018) The Plant Journal 94: 548561; doi: 10.1111/tpj.13878.

Ascorbate plays an important role in the photosynthesis of seed plants and acts as a cofactor of VDE (Müller-Moulé et al., 2002). This enzyme, activated upon thylakoid lumen acidification, is responsible for the conversion of violaxanthin to zeaxanthin and plays an essential role in the qE component of NPQ (Müller-Moulé et al., 2002).

C. reinhardtii has a VDE enzyme which is significantly different from that of seed plants: CrVDE is related to a lycopene cyclase of photosynthetic bacteria, and it is located on the stromal side of the thylakoid membrane (Li et al., 2016b). Besides, it is unknown whether Asc is a cofactor of CrVDE and in general, the role of Asc in the NPQ of green algae is poorly studied. We have found that:

- $\quad$ As opposed to seed plants, in the green alga C. reinhardtii Asc is not required as a co-factor for VDE;

- Under photomixotrophic growth at normal light intensities, $\mathrm{H}_{2} \mathrm{O}_{2}$ enhances the slow component of NPQ; 
- If the cultures are kept under photoautotrophic conditions at high light intensities, the lack of Asc causes photoinhibition, which is probably triggered by $\mathrm{H}_{2} \mathrm{O}_{2}$ accumulation.

Based on these results, a manuscript is in preparation for publication. 



\section{Összefoglalás}

\section{1.) Bevezetés}

A C. reinhardtii nevü egysejtü zöldalga a heterotróf növekedésre való képességének köszönhetően kiváló modellorganizmus mind a fotoszintézis, mind a kloroplasztisz biogenezisének vizsgálatára. A heterotróf anyagcsere révén az egyébként letális fotoszintetikus mutánsok is életben tarthatók az acetát, mint kizárólagos szénforrás jelenlététben (Harris, 2001). A Chlamydomonas, mint modellrendszer másik nagy előnye, hogy jelenleg ez az egyetlen olyan fotoszintetikus szervezet, amelyben az összes, önálló genetikai állománnyal rendelkező sejtalkotó, a sejtmag, a kloroplasztisz és a mitokondrium genetikailag transzformálható (Nickelsen., 2005). Az újabb molekuláris biológiai technikák (amiRNS és CRISPR/Cpf1) szintén jól alkalmazhatók Chlamydomonas modellrendszerekben.

Az aszkorbát (Asc) létfontosságú szerepet játszik növényekben és állatokban egyaránt. Nélkülözhetetlen a reaktív oxigénformák (ROS), mint a szinglet oxigén és a szuperoxid anion semlegesítésében, továbbá kofaktora több, 2-oxosav függő dioxigenáz enzimnek, amelyek számos fontos élettani folyamatot katalizálnak. Magasabb rendü növényekben az antioxidáns hatása mellett az Asc szintén szerepet játszik a sejtosztódásban és a sejtfal kialakulásában, befolyásolja számos jelátvivő molekula (gibberellinek, etilén, szalicilsav, abszcizinsav) szintézisét, szabályozza a sztómák nyitódását és az antocianin termelődését a növények magas fényintenzitáshoz való alkalmazkodása során. Ezek mellett képes befolyásolni egyes fotoszintetikus és fénystressz elleni védelemben szerepet játszó gének expresszióját. A violaxantin deepoxidáz enzim kofaktoraként részt vesz az ún. nem-fotokémiai kioltás (NPQ) folyamatában is.

Magasabb rendü növényekben az Asc elsősorban az L-galaktóz, vagy másnéven Smirnoff-Wheeler bioszintetikus úton termelödik. Ezen bioszintézis út kulcs enzimeiben hiányos mutánsok nem képesek kialakítani a vad típusra jellemző Asc szintet. Az Asc termelődés sebességét leginkább a GDP-L-galaktóz foszforilázt kódoló gén, a VTC2 expressziós szintje határozza meg, amit a vtc2-1 Arabidopsis mutánsok Asc szintjében megfigyelhető 80\%-os csökkenés is alátámaszt (Conklin és mtsai., 2000; Müller-Moulé és mtsai., 2002, 2004). 
A C. reinhardtii zöldalga genomja tartalmazza a Smirnoff-Wheeler Asc bioszintézis út összes enzimének génjét. Génexpressziós vizsgálatok alapján valószínűsíthető, hogy hasonlóan a magasabb rendü növényekhez, az algában található GDP-L-galaktóz foszforiláz expressziója is nagymértékben szabályozott (Urzica és mtsai., 2012). Az Asc bioszintézise és annak szabályozása még kevésbé tanulmányozott alacsonyabb rendű növényekben és zöldalgákban, melyekre általánosan jellemző, hogy kis mennyiségben tartalmaznak aszkorbátot.

A közelmúltban kimutattuk, hogy az aszkorbátnak fontos szerepe van a $C$. reinhardtii fotobiológiai hidrogéntermelésében (Nagy és mtsai., 2016). Megvilágítás hatására a második fotokémiai rendszer (PSII) vízbontó komplexe (OEC) katalizálja a víz oxidációját, amely elektronokat szolgáltat a fotoszintetikus széndioxid redukció számára. Kimutattuk, hogy kénmegvonás hatására az Asc nagy mennyiségben felhalmozódik az algasejtben, és redukáló erejének köszönhetően inaktiválja az OEC-t. Az Asc, mint alternatív elektron donor képes ugyan elektronokat adni a PSII-nek, de ennek sebessége nem elegendő a donor-oldali fotoinhibíció elkerülésére, aminek eredményeképpen a PSII reakciócentrumok inaktiválódnak. A vízbontó képesség megszűnése anaerob körülmények kialakulásához vezet, ami a hidrogéntermelés megindulásának feltétele (Nagy és mtsai., 2016). A kénmegvonás során az Asc a PSII inaktiválásában betöltött szerepének feltárása még további kísérleteket igényelt.

A fotoszintetizáló szervezetek növekedéséhez a fény elengedhetetlen, azonban a felesleges mennyiségü fényenergia ártalmas is lehet. Nem-fotokémiai kioltásnak (NPQ) nevezzük azokat a fotoprotektív folyamatokat, melyek a feleslegben elnyelt fényenergiát hő formájában disszipálják. Az NPQ a fényintenzitás gyors fluktuációjára adott válaszoktól a hosszútávú fénystresszhez való alkalmazkodásig terjed. Az NPQ egyik fő komponense magában foglalja a violaxantinból a zeaxantinba történő átalakulást, amelyet a violaxatin deepoxidáz (VDE) enzim katalizál. A C. reinhardtii VDE enzime (CrVDE) különbözik a más algákban, ill. magasabb rendű növényekben található VDE enzimektől (Li és mtsai., 2016b), és nem ismeretes, hogy az Asc szükséges-e kofaktorként a CrVDE müködéséhez, mint ahogy azt a növényi VDE esetén korábban megfigyelték.

\section{2.) Célkitűzés}

- $\quad$ Az Asc bioszintézis szabályozásának és élettani szerepének vizsgálata $C$. reinhardtii algában 
- Az Asc PSII inaktiválásában betöltött szerepének meghatározása a kénmegvonással indukált hidrogéntermelés során

- $\quad$ Annak meghatározása, hogy az Asc szükséges-e kofaktorként a CrVDE enzim aktivitásához, ill. az Asc NPQ mechanizmusban játszott szerepének vizsgálata.

\section{3.) Alkalmazott módszerek}

- $\quad$ amiRNS;

- C. reinhardtii nukleáris transzformációja;

- $\quad$ cDNA szintézis;

- $\quad$ Chl $a$ fluoreszcencia;

- $\quad$ DNS és RNS izolálás;

- $\quad$ Fehérjeizolálás;

- $\quad$ GC-MS;

- $\quad$ HPLC;

- ICP-OES;

- $\quad$ Northern blott;

- $\quad$ PCR és qRT-PCR;

- $\quad$ Termolumineszcencia;

- Tilakoid izolálás.

- Western blott;

\section{4.) Az eredmények összefoglalása}

Az Asc bioszintézise és annak szabályozása kevésbé tanulmányozott az alacsonyobb rendü növények esetében. A $C$. reinhardtii zöldalga genomjában megtalálható az aszkorbát bioszintézis Smirnoff-Wheeler útjának minden enzime, élettani jelentősége még nem volt bizonyított. Jelen dolgozatban emellett azt is kimutattuk, hogy az aszkorbát bioszintézise zöldalgákban a növényekétől eltérő mechanizmussal szabályozódik:

- Chlamydomonasban a VTC2 gén expresszióját nem befolyásolja közvetlen módon a fotoszintetikus elektrontranszport lánc;

- A magasabb rendü növényekkel ellentétben Chlamydomonasban a VTC2 transzkript szintje nincs cirkadián kontroll alatt; 
- $\quad$ oxidatív stressz hatására a VTC2 expressziója fokozódik, ami nagyon gyors Asc akkumulációt eredményez;

- $\quad$ Fiziológiás Asc koncentráció-tartományban az Asc bioszintézise negatív visszacsatolás által nem szabályozott.

A fenti eredményekből a következő publikáció készült: Vidal-Meireles és mtsai. (2017) New Phytologist 214: 668-681, doi: 10.1111/nph.14425.

C. reinhardtii algában kénmegvonás okozta stressz hatására az Asc koncentrációja olyan mértékben megnövekedhet, ami már képes inaktiválni a vízbontó komplexet, ami végső soron hipoxia kialakulását, majd a hidrogéntermelés megindulását eredményezi. E korábbi eredményeinkből kiindulva (Nagy és mtsai., 2016), célul tűztük ki az Asc e folyamatokban játszott szerepének pontosabb tisztázását és a következőket állapítottuk meg:

- $\quad A z$ általánosan elfogadott hipotézissel szemben a PsbA mennyiségének nagymértékű csökkenését a kénmegvonás során nem közvetlenül a sejtek kéntartalmának csökkenése okozza;

- $\quad$ A PsbA fehérje újraképződése (turnover) jelentős a kénmegvonás alatt;

- $\quad$ A kénmegvonás alatt a VTC2 gén transzkript mennyiségének növekedése az Asc koncentrációjának mM-os tartományba való felhalmozódásához vezet;

- A PSII aktivitás csökkenését a megnövekedett Asc koncentráció által elősegített donor oldali fotoinhibíció okozhatja.

A fenti eredményekből a következő publikáció készült: Nagy és mtsai. (2018) The Plant Journal 94: 548-561; doi: 10.1111/tpj.13878.

$\mathrm{Az}$ Asc fontos szerepet játszik a magasabb rendü növények fotoszintézisében, ill. a VDE enzim kofaktoraként funkcionál (Müller-Moulé és mtsai., 2002). A VDE a tilakoid lumenének savasodására aktiválódik és a violaxantin zeaxantinná alakulását katalizálja, ami fontos mozzanat az NPQ qE komponensének kialakulásában (MüllerMoulé és mtsai., 2002).

A C. reinhardtii VDE enzime a növények VDE enzimétől jelentősen eltér: A CrVDE a fotoszintetikus baktériumok likopén cikláz enzimével mutat rokonságot, és a tilakoid membrán sztróma felőli oldalán helyezkedik el (Li és mtsai., 2016b). Emellett nem ismert, hogy az Asc az algák VDE enzimének kofaktora-e, és általában véve, az 
Asc szerepe az algák NPQ folyamataiban még alig ismert. Ezzel kapcsolatban a következőket állapítottuk meg:

- A magasabb rendü növényekkel ellentétben az Asc nem szükséges a VDE müködéséhez $C$. reinhardtii algában;

- $\quad$ Fotomixotróf körülmények között, normál fényintenzitáson, a $\mathrm{H}_{2} \mathrm{O}_{2}$ növeli az NPQ lassú komponensét;

- $\mathrm{Az}$ algakultúrát fotoautotróf körülmények között és nagy fényintenzitáson az Asc hiánya fotoinhibícióhoz vezet, ami a $\mathrm{H}_{2} \mathrm{O}_{2}$ túlzott fehalmozódásával magyarázható.

Ezen eredmények egy szerkesztés alatt álló kézirat alapját képezik. 



\section{Acknowledgements}

To my supervisor, Dr. Szilvia Zita Tóth for accepting me as a PhD student. It is thanks to her continuous motivation, supervision, understanding, and to all the chances she gave me that this work was possible.

To Dr. László Kovács, for all the technical support and for always being keen on sharing his knowledge with me.

To my lab colleagues (Dr. Valéria Nagy, Dr. Galambos Anikó, Anna Podmaniczki and Dávid Tóth), for setting a friendly working atmosphere.

To Prof. Dr. Ralph Bock, Dr. Juliane Neupert, and the remaining members of the Organelle Biology and Biotechnology group at the Max Planck Institute of Molecular Plant Physiology (Potsdam, Germany), for accepting me as a guest student and for teaching me many of the techniques employed in my thesis.

To Dr. Garab Győző, Dr. Petar Lambrev and the members of Laboratory of Photosynthetic Membranes for all the valuable discussions and friendships established during my stay.

To Dr. László Szabados and Dr. Laura Zsigmond, for all the technical support.

To Dr. Milán Szabó for his criticism and suggestions to improve my thesis as the reviewer of my home defense.

To our assistants (Mariann Balla, Eszter Széles, Dóra Szarka) for all the technical assistance.

To Judit Fábián-Barna, Mariann Károlyi, and other BRC administration staff for their assistance throughout my stay and thesis work.

To my parents and sister, for all the sacrifices they endured so I could reach this point in my career. I won't ever be able to pay back for such a gift and for that I will be eternally grateful for your help, motivation and unconditional love.

To all the friends I made during this journey, for all the support, for always staying on my side, and for helping me to be a better person.

This work was supported by the program Lendület/Momentum Program of the Hungarian Academy of Sciences (LP-2014/19), National Research and Innovation Office (NKFIH, NN 114524, and GINOP-2.3.2-15-2016-00026). 



\section{1.) INTRODUCTION}

\section{1) Green algae and their ecological importance}

The term algae incorporate a group of several photosynthetic organisms, including prokaryotic cyanobacteria, eukaryotic microalgae, and some macroalgae and other marine species (Lee, 2008). Eukaryotic microalgae are not differentiated into shoots or root and comprise uni- or multicellular forms and play an important role in the environmental carbon sequestration (Renuka et al., 2018). Since they have basic nutrient requirements, a high growth rate, and a resistant nature under different environmental stimuli, microalgae can be used for biomass production, or for the synthesis of different bioactive compounds and bioenergy (Vu et al., 2018).

Algal biofuel has been recognized as a potential alternative renewable energy source, with the potential to replace fossil-based fuels such as carbohydrates, lipids and fatty acids (Singh et al., 2017). Furthermore, some microalgae, such as the green alga Chlamydomonas reinhardtii, are capable of releasing $\mathrm{H}_{2}$ simply by converting the energy of light under certain physiological conditions. The potential for sustained $\mathrm{H}_{2}$ photo-production has driven research into finding the optimal conditions for fuel production (Torzillo et al., 2015).

\subsection{1) The green alga Chlamydomonas reinhardtii as a model organism}

The typical wild-type $C$. reinhardtii cell (Figure 1) has about $10 \mu \mathrm{m}$ in diameter and is enclosed within a wall consisting mainly of hydroxyprolin-rich glycoproteins. A large number of mutants with defects in cell wall biosynthesis have been isolated, which are capable of synthesizing the precursor proteins of the wall in normal amounts but fail to assemble them into a complete structure. The so called "cell-wall deficient" mutants are widely used as recipients for genetic modifications.

A single cup-shaped chloroplast occupies the basal two thirds of a Chlamydomonas cell and it partially surrounds the nucleus. A distinctive body within the chloroplast, the pyrenoid, is the place of $\mathrm{CO}_{2}$ fixation. Starch bodies surround the pyrenoid and they are also seen dispersed throughout the chloroplast under some special conditions (Harris, 2001; Nickelsen, 2005).

C. reinhardtii has emerged as an excellent model system to study both photosynthesis and biogenesis of the chloroplast, mostly due to its capability for 
mixotrophic growth, using acetate as a carbon source (as opposed to the traditional autotrophic growth, where atmospheric $\mathrm{CO}_{2}$ is used as the sole carbon source); thanks to this property, mutants deficient in photosynthesis are viable, provided that acetate is added to the growth medium and when the cells are placed in the dark (Harris, 2001). Another advantage of using Chlamydomonas as a model system is that it represents the only photosynthetic organism that is suitable for transformation of all genetic compartments: nucleus, chloroplast, and mitochondria (Nickelsen, 2005).

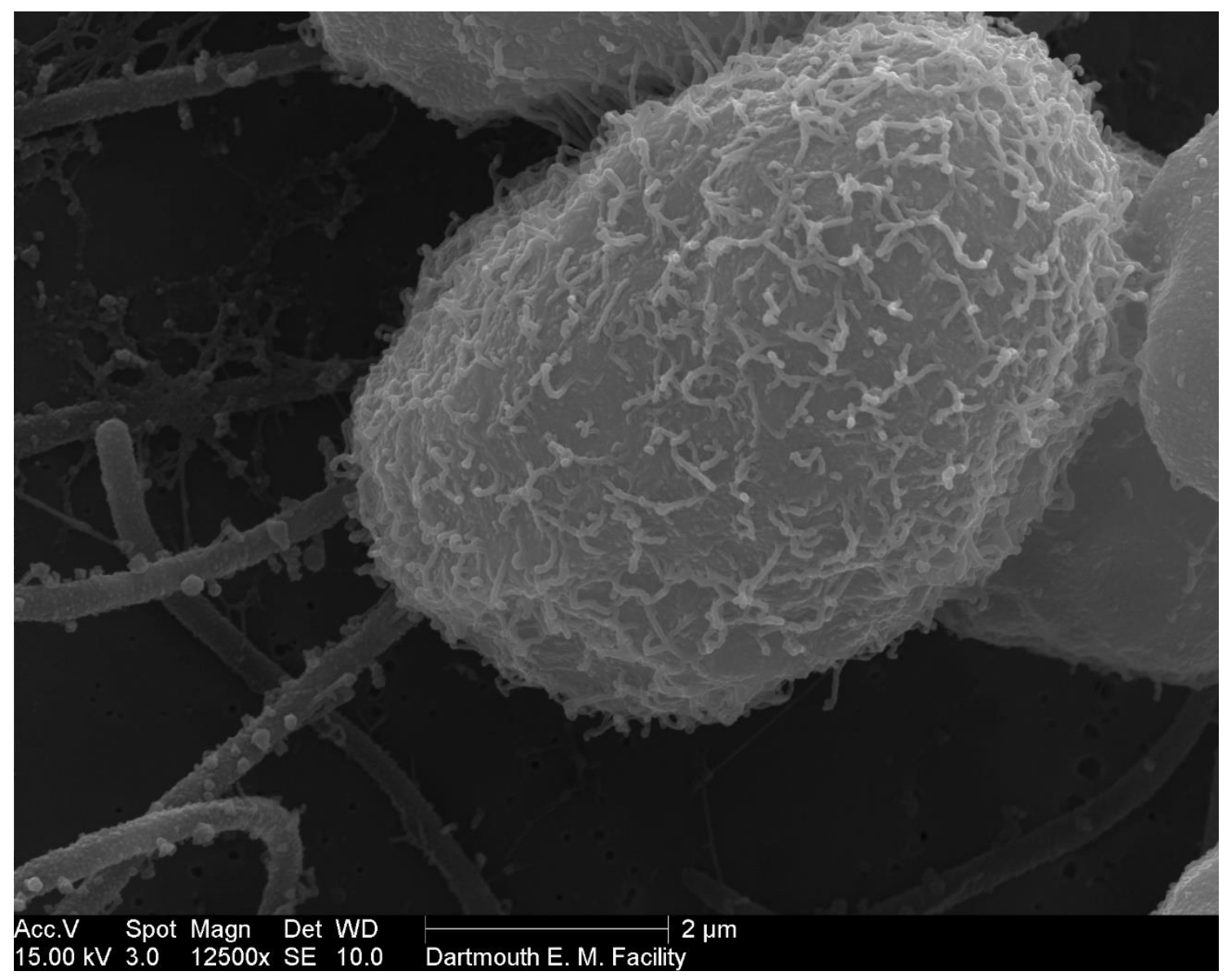

Figure 1. C. reinhardtii image obtained via scanning electron microscopy. [Source: US National Science Foundation -

https://www.nsf.gov/news/mmg/mmg_disp.jsp?med_id=79710\&from=, accessed on 2018.05.17]. 


\section{2) Photosynthesis}

Photosynthesis is the most important light-induced process, which allows eukaryotic and prokaryotic photosynthetic organisms to convert light energy into chemical products. Photosynthesis can be anoxygenic (for example in purple sulfur bacteria), when water is not the primary electron donor and no oxygen is produced, or oxygenic (as for plants, green algae, and cyanobacteria), where water oxidation leads to oxygen production and reduction of $\mathrm{CO}_{2}$ to carbohydrates (Mirkovic et al., 2017).

Photosynthesis comprises photophosphorylation reactions, where sunlight is harvested, and its energy is used to produce ATP and to reduce ferredoxin and NADP ${ }^{+}$, and Calvin-Benson-Bassham (CBB) cycle reactions, which involve the uptake of $\mathrm{CO}_{2}$ and its conversion to carbohydrates. The light-dependent reactions take place in the thylakoid membranes of the chloroplasts, more specifically in the reaction centers of photosystem (PS) I and II, each associated with various light-harvesting complexes, consisting of proteins, chlorophylls, carotenoids, and phycobilins. Carbon fixation takes place in the chloroplast stroma (Nelson and Ben-Shem, 2004).

Light-harvesting complexes (LHC) are crucial for photosynthetic reactions, since they ensure, through a combination of an increase in effective absorption of sunlight, a steady supply of excitation energy into each photosynthetic reaction center (Mirkovic et al., 2017). The pigments in the LHC antenna are responsible for the absorption of photons, and to funnel it into a photochemical reaction center, where charge separation occurs with almost $100 \%$ quantum efficiency. The need for such an elaborate energy-collecting system comes from the fact that reaction center chlorophylls (Chl) can only absorb a few photons per second, so the LHCs associate additional pigments to each reaction center that will efficiently drive the electron transfer process at a rate required for an efficient photosynthesis to occur (Mirkovic et al., 2017).

Photosynthesis operates in a $Z$ scheme (Figure 2), that accounts for the production of a strong oxidant by PSII (P680), capable of oxidizing water, after the absorption of light; the oxidation of water generates a weak reductant (P680*), that transfers electrons through an electron transport chain until it reaches PSI. At the PSI site, a weak oxidant (P700) is the early acceptor of the electrons and it gets reduced $(\mathrm{P} 700 *)$, generating a molecule capable of reducing $\mathrm{NADP}^{+}($Nelson and Ben-Shem, 2004). 


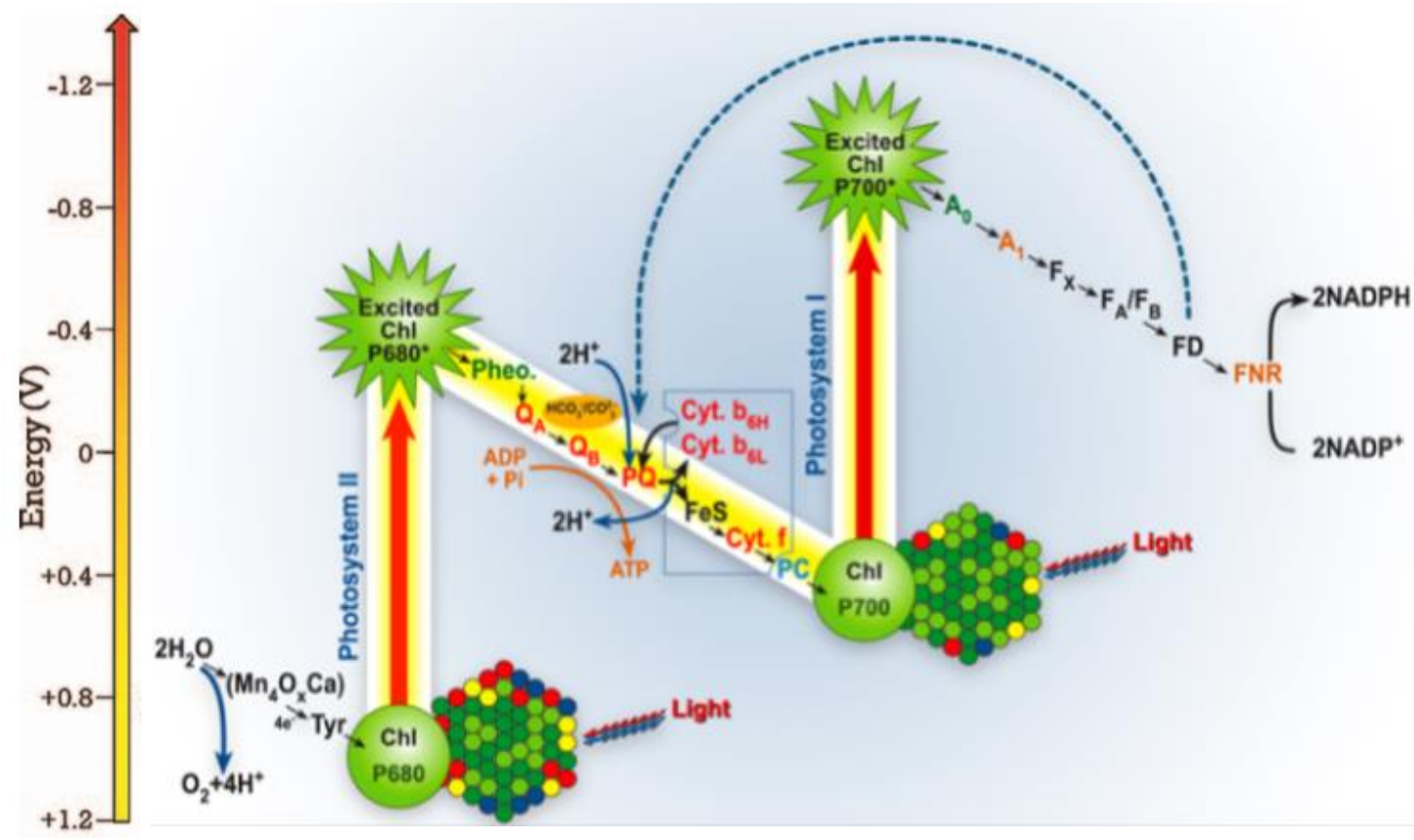

Figure 2. Z-scheme of the photosynthetic light reactions. [Source: University of Illinois, Department of Plant Biology http://www.life.illinois.edu/govindjee/2010_z-scheme.pdf, accessed on 2018.05.17].

The photoinduced oxidation of water, primary source of reducing equivalents for photosynthesis, takes place in the oxygen-evolving complex (OEC) of PSII (Ferreira, 2004). The OEC sits approximately at the membrane-lumen interface, surrounded by four core proteins (PsbA [D1], PsbD [D2], CP43, and CP47) of PSII, and protected by three OEC-proteins (PSBO, PsbQ, and PsbR in seed plants) (Raymond and Blankenship, 2008). At the center of the OEC there is a Mn cluster, a catalytic site responsible to feed the electrons from water oxidation into the tyrosyl radical, the electron donor of $\mathrm{P} 80^{+}$(Charles Dismukes and van Willigen, 2006).

The OEC is a very vulnerable complex of the photosynthetic electron transport chain, being the first target of donor-side induced photoinhibition; inactivation of the OEC includes the removal of the extrinsic shielding proteins, as well as the release of $\mathrm{Ca}$ and Mn ions from their binding sites (Barra et al., 2005; Enami et al., 1994; Nash et al., 1985). When OEC is inactivated, the supply of electrons from water is interrupted and the residual electron transport activity of PSII is rapidly lost, resulting in the loss of the capacity for primary charge separation and the degradation of the PSII core, unless an alternative pool of donors is available to prevent the full inactivation of the OEC (Blubaugh et al., 1991; Jegerschöld and Styring, 1996; Klimov et al., 1990). Amongst 
the putative alternative electron donors for PSII, ascorbate (Asc) is the only confirmed donor in vivo. Present in the lumen at millimolar concentrations in higher plants, Asc serves as a relatively fast electron donor to PSII when the OEC is not active, thus protecting PSII (Tóth et al., 2011).

\section{3) Ascorbate}

Ascorbate is one of the most widely known vitamins (Figure 3), and it features several essential functions both in animals and plants (Tóth et al., 2018). In higher plants, besides playing a role as an antioxidant, Asc also regulates the cell cycle (Gallie, 2013; Potters et al., 2000), and it modulates the synthesis of several signaling molecules such as abscisic acid, gibberellins (López-Carbonell et al., 2006; Pastori, 2003), ethylene (McGarvey and Christoffersen, 1992) and salicylic acid (Barth, 2004). Ascorbate can also influence anthocyanin accumulation during high-light acclimation (Page et al., 2012), is involved in the regulation of stomatal movement (Fotopoulos et al., 2008) and modulates the expression of specific sets of photosynthesis and defense genes (Kiddle et al., 2003). Through its role as a cofactor of violaxanthin deepoxidase (VDE), Asc also contributes to nonphotochemical quenching (NPQ) in seed plants (Müller-Moulé et al., 2002). Furthermore, it is an alternative electron donor to PSII (Tóth et al., 2009, 2011) and we recently demonstrated that, in Chlamydomonas reinhardtii, Asc influences photobiological $\mathrm{H}_{2}$ production under sulfur deprivation (Nagy et al., 2012).

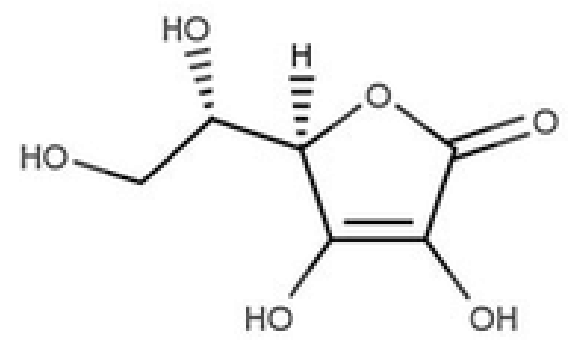

Figure 3. L-Ascorbic acid molecule.

Ascorbate is present in most cellular compartments and its concentration varies between different tissues of the same plant and between cultivars of the same species, 
and there is also a large variation in its subcellular concentration; the Asc concentration is also influenced by the environment. Typically, in Arabidopsis, Asc accumulates to about 5-6 mM cellular concentration (Conklin et al., 2000; Zechmann et al., 2011); under normal physiological conditions, the Asc concentration of $C$. reinhardtii cells is 100 times lower than in higher plant cells (Gest et al., 2013; Wheeler et al., 2015). There is an intricate regulation of Asc biosynthesis, and the total concentration in the plant tissues comes from the balance between catabolism and synthesis. Catabolism is the result of breakdown of oxidized forms of Asc to diketogulonic acid and other compounds and these processes may deplete the total Asc pool if the biosynthesis processes are unable to restore the needed concentrations (Bulley and Laing, 2016).

\subsection{1) Ascorbate biosynthesis}

In higher plants, the main Asc biosynthesis pathway is the L-galactose pathway, usually referred as the "Smirnoff-Wheeler" pathway; this is the main contributor for Asc synthesis in higher plants, which has been proven by the fact that in mutants targeting key enzymes of this pathway are unable to compensate the loss of the Asc biosynthetic capacity. Additional pathways have been suggested to be present: the Lgulose pathway, the galacturonate (also known as "pectin scavenging") pathway, and the animal-like Asc biosynthesis ("myo-inositol") pathway (Gallie, 2013; Tóth et al., 2018) (Figure 4).

The Smirnoff-Wheeler pathway involves 10 enzymatic steps to convert Dglucose to L-ascorbate via formation of GDP-D-mannose and L-galactose containing intermediates (GDP-L-galactose, L-galactose-1-P, L-galactose, and L-galactono-1,4lactone). The final step, in which L-galactono-1,4-lactone is oxidized into Asc is catalyzed by galactono-1,4-lactone dehydrogenase, takes place in the mitochondria (Wheeler et al., 1998). The rate of Asc biosynthesis is largely determined by the expression level of $V T C 2$, encoding GDP-L-galactose phosphorylase, as demonstrated by the vtc2-1 Arabidopsis mutant which contains about $80 \%$ less Asc relative to its control strain (Conklin et al., 2000; Müller-Moulé et al., 2002, 2004). It has been also shown that the expression level of VTC2 strongly responds to high light and is regulated by the circadian clock (Dowdle et al., 2007).

The genome of the model green alga $C$. reinhardtii encodes all the enzymes of the Smirnoff-Wheeler Asc biosynthesis pathway; based on gene expression analysis, it was suggested that the algal GDP-L-galactose phosphorylase is a highly regulated 
enzyme, similarly to higher plants (Urzica et al., 2012). Overall, Asc biosynthesis and its regulation are poorly studied in non-vascular plants and green algae, organisms that possess low Asc contents.

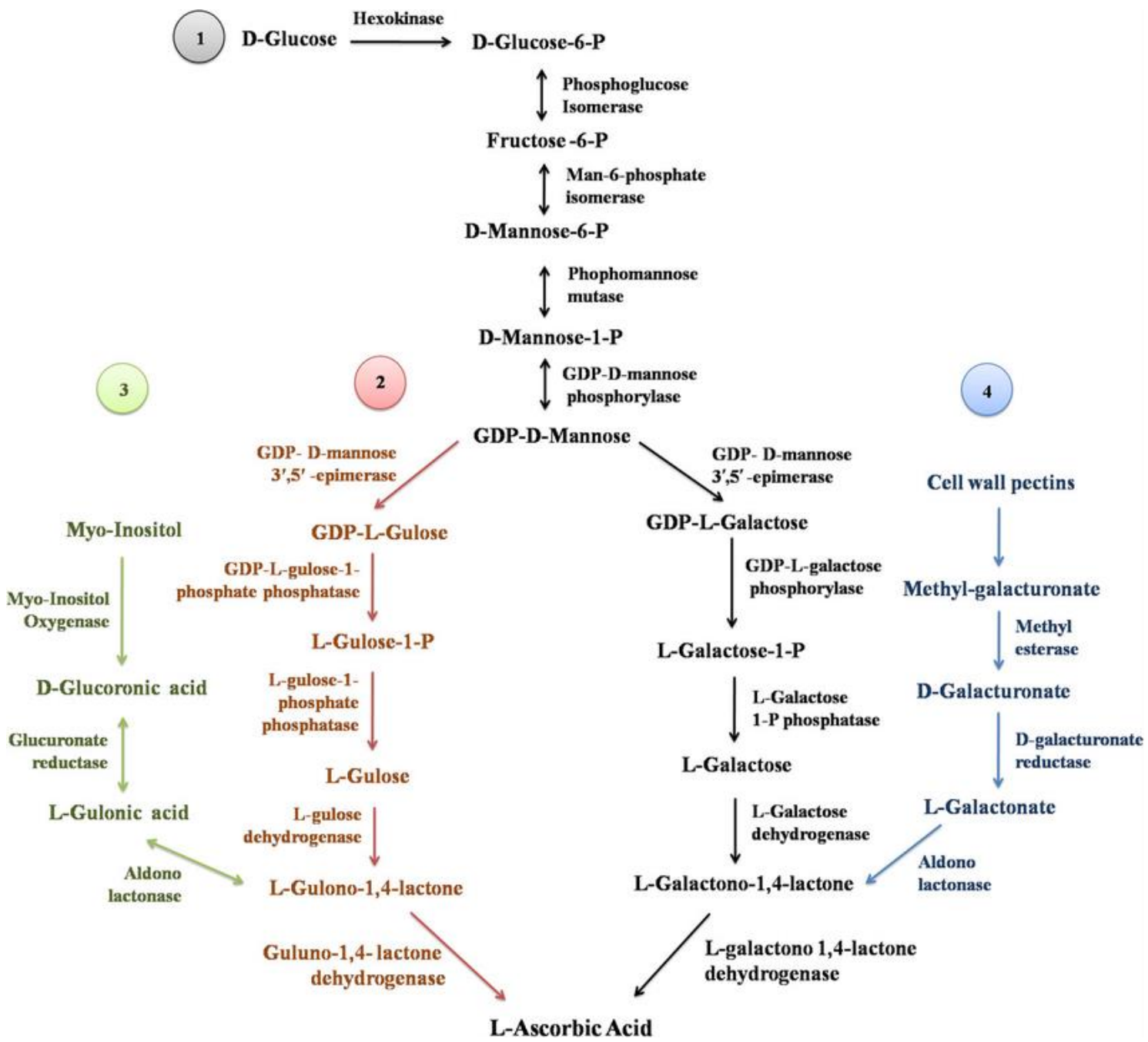

Figure 4. The different ascorbate biosynthesis pathways: (1) SmirnoffWheeler pathway, (2) L-gulose pathway, (3) Myo-inositol pathway, (4) Galacturonate pathway [Source: Venkatesh and Park, 2014].

\subsection{2) The role of Asc under environmental stress conditions}

Under stress conditions, including UV-B (Gao and Zhang, 2008), ozone (Caregnato et al., 2013), salt (Huang et al., 2005) and high light stress (Bulley and Laing, 2016; Dowdle et al., 2007), a two- to three-fold increase in Asc levels can be observed on the timescale of days. Ascorbate biosynthesis is also dependent on photosynthetic electron transport (Kiyota et al., 2006), possibly due to the generation of 
reactive oxygen species (ROS). In plants, the signaling pathways of hydrogen peroxide $\left(\mathrm{H}_{2} \mathrm{O}_{2}\right)$ and singlet oxygen $\left({ }^{1} \mathrm{O}_{2}\right)$ are very complex and appear to be integrated with many different signaling networks, including protein kinase networks, calcium signaling metabolic networks and redox responses (Mittler et al., 2011). In addition, ROS may act as chloroplastic retrograde signals and play an important role in environmental acclimation (Chi et al., 2015; Suzuki et al., 2012). Ascorbate prevents the overaccumulation of ROS, which are formed during photosynthetic reactions occurring in the chloroplast, as a by-product of respiration in the mitochondria, and that are formed in the peroxisomes, due to their oxidative metabolism (Del Río and López-Huertas, 2016; Huang et al., 2005). As a non-enzymatic antioxidant, Asc is able to detoxify ${ }^{1} \mathrm{O}_{2}$ and scavenge lipid peroxyl radicals, thus participating in the tocopherol recycling in plants as well (Munné-Bosch, 2005).

Ascorbate, alongside catalases, contributes to the elimination of $\mathrm{H}_{2} \mathrm{O}_{2}$ via the ascorbate-glutathione cycle, where Asc is regenerated by reduced glutathione via dehydroascorbate (DHA) reduction (Asada, 2006; Foyer and Noctor, 2011). This cycle acts throughout the entire cell, in chloroplasts, cytoplasm, mitochondria, and peroxisomes (Foyer and Noctor, 2011; Jimenez et al., 1997). It comprises four glutathione S-transferase enzymes, ascorbate peroxidase (APX), monodehydroascorbate reductase (MDAR), dehydroascorbate reductase (DHAR), and glutathione reductase (Foyer and Noctor, 2011).

\subsection{2) Ascorbate regeneration}

Cellular Asc levels are regulated not only at its biosynthesis, but also at its regeneration process. During the scavenging of organic radicals and ROS, Asc can become oxidized to monodehydroascorbate (MDA); MDA is also produced by VDE and when Asc acts as an alternative donor to PSII. MDA is reduced back to Asc via ferredoxin or by the MDAR enzyme, otherwise it spontaneously disproportionate into Asc and DHA. DHA is further reduced by DHAR into Asc, thus maintaining the Asc concentration stable in the different cellular compartments; if DHA is not reduced, it is irreversibly hydrolyzed and the total Asc pool decreases (Tóth et al., 2018).

Ascorbate degradation in plants may also control its concentration; the major Asc degradation route in seed plants occurs via DHA, which yields as final products oxalate and L-threonate. Asc degradation is also stimulated by darkness, and the Asc pool has a half-life of approximately 1 day in higher plant leaves, independently of the 
size of the pool and the oxidation state of Asc (Green and Fry, 2005; Truffault et al., 2017).

\section{4) Hydrogen photoproduction in Chlamydomonas reinhardtii}

Solar-energy-driven hydrogen production by photosynthetic microorganisms may become an alternative method to complement the proposed chemical technologies to produce $\mathrm{H}_{2}$ gas. C. reinhardtii is one of the most popular organisms used in the research on the photoproduction of $\mathrm{H}_{2}$ (Torzillo et al., 2015). It contains two [Fe-Fe]type hydrogenases located in the chloroplasts stroma that can receive electrons from ferredoxin, located on the acceptor side of PSI (igure 5). The Chlamydomonas hydrogenases serve as a safety valve against the over-reduction of the electron transport chain, reducing the risk of photodamage; they are able to modulate the ATP-to-NADPH ratio and accelerate the light-induced increase in stromal $\mathrm{pH}$, triggering $\mathrm{CO}_{2}$ fixation (Ghysels et al., 2013; Godaux et al., 2015).

Algal hydrogenases are highly efficient, with a turnover rate 100-fold higher than other types of hydrogenase (Rousset and Liebgott, 2014), but they are very sensitive to $\mathrm{O}_{2}$ and, because of that, under normal conditions $\mathrm{H}_{2}$ production lasts only for a few seconds upon the induction of photosynthesis (Forestier et al., 2003). Sustained $\mathrm{H}_{2}$ production can be achieved by sulphur-deprivation (Kosourov and Seibert, 2009; Melis et al., 2000), which results in a loss of PSII, Rubisco, and PSI (Kosourov et al., 2002; Melis et al., 2000; Wykoff et al., 1998; Zhang et al., 2002). This loss of photosynthetic activity is accompanied by starch accumulation and maintained cellular respiration, and consequently there is a transition from an aerobic to an anaerobic state. The establishment of anaerobiosis induces the expression of the hydrogenase enzymes and the production of $\mathrm{H}_{2}$ for several days depending on the experimental conditions (Melis et al., 2000). 


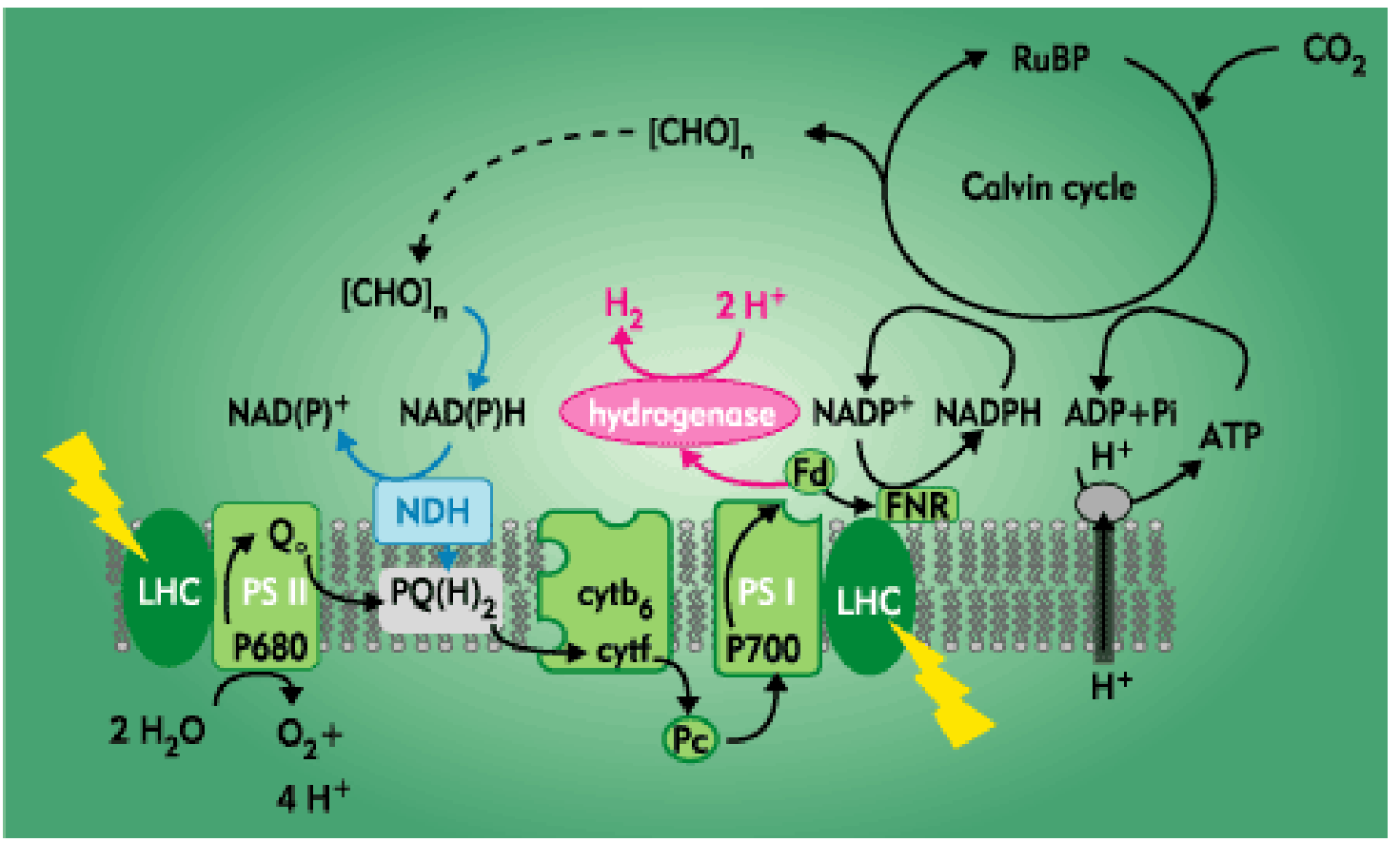

Figure 5. The photosynthetic electron transport chain of $C$. reinhardtii. [Source: University of Liège, $\mathrm{MicroH}_{2}$ project http://www.microh2.ulg.ac.be/PROJECT2.html, accessed on 2018.05.17].

\subsection{1) Ascorbate modulates the initiation of the $\mathrm{H}_{2}$ production in $C$.} reinhardtii

Originally, it has been proposed that upon sulphur deprivation, the inactivation of PSII resulted from an imbalanced photoinhibition and repair of the PsbA protein (Zhang et al., 2002). However, since changes in gene expression occur within hours, and sulphur-deprivation promotes a complex adaptation process (Gonzalez-Ballester et al., 2008; Toepel et al., 2013), it might not be necessarily the lack of sulphur that hinders the turnover of the PsbA protein in non-dividing cultures under sulphur-free conditions.

We showed recently that Asc might have an important modulatory effect on the photobiological $\mathrm{H}_{2}$ production in $C$. reinhardtii (Nagy et al., 2016). Upon sulphur deprivation, Asc accumulates dramatically and it inactivates the Mn-cluster; even though Asc can donate electrons to PSII, that happens at a slow rate and donor-side induced photoinhibition takes place, causing a loss of the charge separating activity of PSII; these events act in parallel with the establishment of anaerobiosis, which is essential for $\mathrm{H}_{2}$ production (Nagy et al., 2016). However, the exact mechanism by which Asc may induce the inactivation of PSII during sulphur deprivation-induced $\mathrm{H}_{2}$ production in $C$. reinhardtii remained unclear. 


\section{5) Non-photochemical quenching}

For photosynthetic organisms, light absorption is required for growth, but too much light can be harmful. Under low-light conditions, the rate of photon absorption is well matched with the rate of photosynthesis, contributing to maximal photosynthetic efficiency; as light intensity increases, the rate of photosynthesis becomes saturated even though the excess photons are still absorbed: If the organism cannot handle overexcitation, damaging byproducts may accumulate, which trigger photo-oxidative damage to PSII and PSI, and to other molecules in the cell (Niyogi, 1999).

C. reinhardtii has evolved different mechanisms to minimize the damage caused by excess light. When high light cannot be avoided, the cells can regulate light harvesting by dissipating excess absorption as heat, changing the rate of electron transport, or readjusting the light-harvesting antenna size (Melis, 1991; Smith et al., 1990; reviewed by Erickson et al., 2015). Additionally, repair mechanisms regulate PSII turnover to maintain photosynthetic capacity, and changes in gene expression (transient repression of the genes encoding the major and minor PSII-associated LHC antenna proteins) help the cell acclimate to the new conditions, while accumulation of antioxidants helps to eliminate ROS in the chloroplast (Erickson et al., 2015).

The photo-protective mechanisms responsible for dissipating the excess energy as heat are collectively called non-photochemical quenching (NPQ). NPQ includes short-term responses to rapid fluctuations in light, as well as responses that occur over longer periods allowing for acclimation to high light exposure. There are four types of NPQ (Figure 6), which are distinguished by the time scales of their induction and relaxation: energy-dependent quenching (qE), zeaxanthin-dependent quenching (qZ), photoinhibitory quenching (qI), and state transition-dependent quenching (qT) (Erickson et al., 2015). 


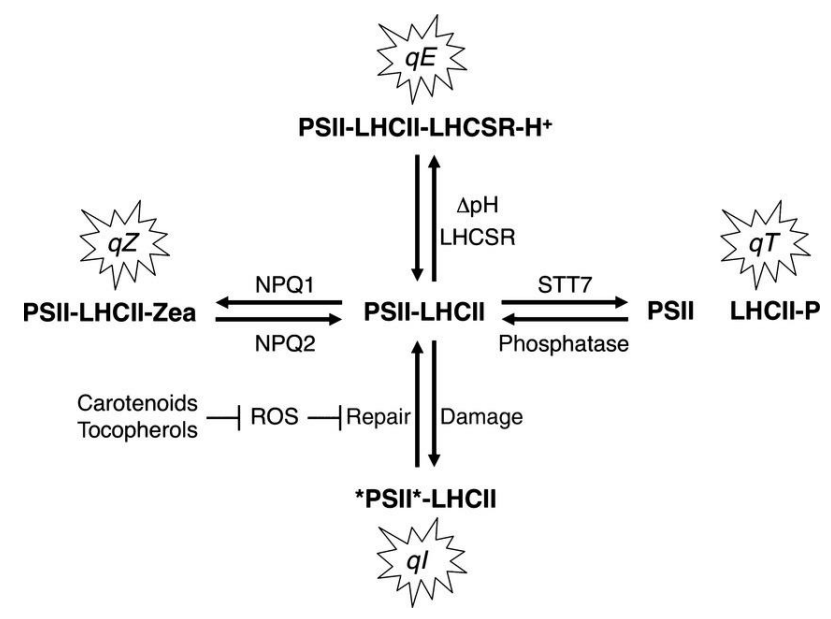

Figure 6. The different non-photochemical quenching mechanisms in $C$. reinhardtii [Source: Erickson et al., 2015].

\subsection{1) Energy-dependent quenching (qE)}

Quick fluctuations in light intensity require mechanisms to dissipate excess absorbed light energy to avoid high light stress. qE can be induced in a matter of seconds and relaxes over the course of minutes. It protects the photosynthetic apparatus by i) decreasing the lifetime of reactive chl species in PSII (thus decreasing ${ }^{1} \mathrm{O}_{2}$ generation), ii) preventing the over-reduction of the electron carriers in the plastoquinone pool, iii) minimizing the over- acidification of the thylakoid lumen, which could damage the OEC (Aro et al., 1993; Kramer et al., 1999; Virgin et al., 1988). $\mathrm{qE}$ induction requires the formation of a proton gradient $(\Delta \mathrm{pH})$ across the thylakoid membrane and, in C. reinhardtii, a stress-related LHC protein, LHCSR3 (Briantais et al., 1979; Peers et al., 2009). In seed plants, the role of LHCSR3 is taken up by the PsbS protein, and recently it was found that not only C. reinhardtii possesses two PsbS genes (Merchant et al., 2007), but also is able to express them transiently during high light acclimation (Tibiletti et al., 2016).

Under excess illumination, the thylakoid lumen becomes more acidic (there is a build-up in the $\Delta \mathrm{pH}$ across the membrane, generated by photosynthetic electron transport (Muller, 2001). The $\Delta \mathrm{pH}$ increases because ATP is not being consumed fast enough by assimilatory reactions, therefore limiting the proton efflux through the ATPsynthase. The decrease in $\mathrm{pH}$ of the lumen acts as a signal that triggers the protonation of the PSII-associated proteins involved in $\mathrm{qE}$ (Horton et al., 1994, 1996). LHCSR3 has been shown to function as both a sensor of lumen $\mathrm{pH}$ and a site of excited chl quenching, thus playing a role in the dissipation of the excitation energy (Bailleul et al., 
2010; Liguori et al., 2013). In C. reinhardtii, two functional PsbS were also discovered, and they have been shown to be expressed rapidly and transiently only in response to high light stress and without conferring any clear photoprotection (Tibiletti et al., 2016).

In contrast to PsbS, found in seed plants, LHCSR proteins are chlorophyll a/b and xanthophyll-binding proteins. LHCSR3 binds to the PSII-LHCII super-complex, and this complex can dissipate energy at low $\mathrm{pH}$, with LHCSR3 being essential for a high quenching capacity (Xue et al., 2015). After phosphorylation, LHCSR3 may also migrate between PSII and PSI during state transition, a tool for modulating the level of energy quenching in PSII complexes as well as in PSI complexes. The absence of LHCSR3 accelerates photoinhibition of PSI under conditions where PSI is prone to degradation (Xue et al., 2015).

\subsection{2) Zeaxanthin-dependent quenching (qZ)}

Carotenoids are vital components of biological tissues in both plants and animals; they can act as building blocks to aid proteins folding, protect organisms against damaging ROS (particularly ${ }^{1} \mathrm{O}_{2}$ ), serve as accessory pigments that contribute to light-harvesting and energy-transfer processes, and participate in signaling reactions (Mirkovic et al., 2017).

Carotenoids play a key role in NPQ by changing the conformation of LHCII into a quenched state, forming charge-transfer states together with chl and opening fast channels for the quenching of chl excited states. Xanthophylls, which experience conformational change triggered by light fluctuations, are particularly important for the induction of NPQ (Mirkovic et al., 2017).

Upon exposure of dark-acclimated wild-type cells to high light, NPQ induction in $C$. reinhardtii exhibits biphasic kinetics. The initial rapid rise in $\mathrm{qE}$ is attributed to the rapid increase in the $\Delta \mathrm{pH}$ and the presence of lutein when levels of zeaxanthin are low. The second phase shows a slower rise in quenching over the course of a few minutes that corresponds to the accumulation of zeaxanthin; this second phase is called qZ. It is possible, however, that some zeaxanthin-dependent (and $\Delta \mathrm{pH}$-dependent) $\mathrm{qE}$ also contributes to this second phase of quenching. In limiting light, zeaxanthin is epoxidized, regenerating violaxanthin and completing the xanthophyll cycle (Erickson et al., 2015; Hieber et al., 2000).

In a fully de-epoxidized conformation, zeaxanthin increases the thermal dissipation of PSII, whereas violaxanthin (the epoxidized conformation) promotes the 
prevalence of the light-harvesting function (Mirkovic et al., 2017). The qZ mechanism has been mainly described in plants (Nilkens et al., 2010). In seed plants, de-epoxidase activity requires induction of lumen $\mathrm{pH}$ and the presence of Asc (Hieber et al., 2000). Asc, as a co-factor for the VDE enzyme of seed plants, promotes zeaxanthin formation; Asc can also interact directly with zeaxanthin and form a complex to prevent the damage of the LHCs (Horton and Ruban, 2005).

The VDE enzyme of $C$. reinhardtii (CrVDE) differs from the enzyme found in plants and most algae ( $\mathrm{Li}$ et al., 2016b), and it is currently unknown whether Asc is required as a co-factor for the algal-type VDE, and thereby to $\mathrm{qZ}$ induction. Both the plant-type VDE and CrVDE are associated with the thylakoid membrane, but whereas VDE is located in the thylakoid lumen, CrVDE is located on the stromal side of the thylakoid membrane ( $\mathrm{Li}$ et al., 2016b). Furthermore, the evolutionary origins of the plant-type VDE and CrVDE are different, since CrVDE is a homologue of a bacterial enzyme involved in carotenoid biosynthesis, suggesting it might have been acquired via endosymbiosis or an horizontal gene transfer event (Li et al., 2016b).

\subsection{3) Photoinhibitory quenching (qI)}

The most common reactive byproducts of photosynthesis that are formed in aerobic environments are the ROS, a category that includes superoxide, hydroxyl radical, $\mathrm{H}_{2} \mathrm{O}_{2}$, and ${ }^{1} \mathrm{O}_{2}$. ROS are products of over-reduction of the photosynthetic electron transport chain and can cause cellular damage, but they also function as important signaling molecules (Erickson et al., 2015). The chl present in the chloroplast can act as a photosensitizer of $\mathrm{O}_{2}$, forming ${ }^{1} \mathrm{O}_{2}$ through energy transfer. When a chl molecule enters the excited state upon photon absorption, it is in the short-lived singlet excited state; the longer the excitation of chl lasts, the bigger the odds that it enters the triplet excited state, a molecule that has a longer excitation lifetime and can transfer energy to the ground state of $\mathrm{O}_{2} \cdot{ }^{1} \mathrm{O}_{2}$ is predominantly formed at the reaction center of PSII, and it is the main ROS responsible for photo-oxidative damage in plants (Asada, 2006; Erickson et al., 2015).

PsbA, the reaction center protein of PSII, is particularly susceptible to highlight-induced oxidative damage (Aro et al., 1993), because PSII generates a strong oxidant and it is slower at quenching chl excited states by photochemistry as compared to PSI; photodamage to PSII exhibits a linear correlation with light intensity (Erickson et al., 2015). However, PSII has a dynamically regulated repair machinery that can 
selectively degrade and replace photodamaged PsbA, and photoinhibition of PSII only occurs if the rate of repair is unable to keep up with the rate of the damage (Aro et al., 1993).

The speed of PSII repair is controlled by the energetic state of the chloroplast. Photoinhibition of PSII is associated with qI quenching and helps control electron flow to PSI, which might suffer irreversible damage, in case the capacity of the electron acceptors is exceeded (Murata et al., 2012; Tikkanen et al., 2014).

The light sensitivity of PSII and the regulation of the turnover of PsbA, together with $\Delta \mathrm{pH}$ and the regulation of cytochrome $\mathrm{b}_{6} \mathrm{f}$ complex, enable the control of photosynthetic electron flow and prevents the irreversible damage to PSI (Tikkanen et al., 2014). Degradation of the PsbA protein after damage depends on unpacking of the damaged PSII-LHCII complexes and their lateral migration to the stroma membrane. This process seems to be dependent on the phosphorylation of PSII core proteins (reviewed by Tikkanen et al., 2014), and thus suggests that $\mathrm{qI}$ and state transition might function together in the dissipation of excess energy (Roach and $\mathrm{Na}, 2017$ ).

\subsection{4) State transition-dependent quenching (qT)}

In $C$. reinhardtii, state transition is an important short-term response to changing light conditions, whereas in higher plants state transition is minor, playing a role rather in long-term acclimation (Wientjes et al., 2013). Several other processes occur during the qT phase of NPQ in seed plants, including activation of the acceptor side of PSI (Schansker et al., 2006).

C. reinhardtii cells can be either in State 1, where excitation of the photosystems is balanced between the photosystems (LHCII antenna associate with PSII and LHCI antenna with PSI), or in State 2, where the LHCII major and minor antenna proteins dissociate from PSII and associate with PSI (Depege, 2003; Lemeille et al., 2009); some research groups however claim that, even though LHCII antenna dissociate from PSII upon state transition, they never associate with PSI, staying isolated as trimers until they associate once again with PSII (Ünlü et al., 2014). When the light quality changes in favor of PSII, the plastoquinone pool becomes reduced, and the STT7 serine/threonine kinase, responsible for the phosphorylation of the LHCII antenna proteins, is activated, leading to the disassociation of the LHCII from PSII (Lemeille et al., 2009). The process is reversible via TAP38-mediated dephosphorylation of LHCII, an enzyme that may be inhibited under State 2-favoring light conditions, leading to LHCII 
hyperphosphorylation (Pribil et al., 2010). The most heavily phosphorylated LHCII proteins in $C$. reinhardtii include the major antenna proteins LHCBM1, 2, 5, and 7, and the minor antenna proteins CP26 and CP29, all capable of migrating to PSI under state 2 conditions, where they form a super-complex with PSI-LHCI (Drop et al., 2014).

In $C$. reinhardtii, the level of $\mathrm{qE}$ versus $\mathrm{qT}$ is variable and highly dependent on the growth conditions. High-energy quenching $\mathrm{qE}$ is more induced when cells are grown under high light and carbon-limiting conditions, due to the establishment of a high $\triangle \mathrm{pH}$ across the thylakoid membrane and restricted electron flow to the CBB cycle (Finazzi et al., 2006; Iwai et al., 2007). On the other hand, photomixotrophic or heterotrophic growth at normal light intensities may lead to more excitation of PSII over PSI, which will increase the reduction state of the plastoquinone pool and consequently promote the phosphorylation of LHCII proteins, triggering qT (Iwai et al., 2007). 


\section{$\underline{\text { 2.) AIMS }}$}

When this PhD started (2013), Asc biosynthesis and its regulation were poorly studied in green algae, and direct physiological and molecular evidence for the operation of the Smirnoff-Wheeler pathway was still lacking, which gave rise to the main aim of this $\mathrm{PhD}$ project:

- Studying the regulation of the Asc biosynthesis and its physiological importance in Chlamydomonas reinhardtii

Asc is capable of donating electrons to PSII after the OEC is inactivated; it is known that, due to this phenomenon, in certain C. reinhardtii strains Asc substantially improves the photoproduction of $\mathrm{H}_{2}$ (Nagy et al., 2016). As a follow-up of this line of research, another aim for this $\mathrm{PhD}$ project was designed:

- Determination of the role of Asc in the inactivation of PSII during sulphur deprivation-induced $\mathrm{H}_{2}$ production in Chlamydomonas reinhardtii

In seed plants, Asc is a co-factor of VDE and, therefore, involved in the induction of $\mathrm{qE}$ and in the formation of zeaxanthin. Green algae do not possess the plant-type VDE, and instead the so-called CrVDE protein is responsible to de-epoxidize violaxanthin, and it is not known if Asc was required as a co-factor for this protein. Thus, a third aim of this $\mathrm{PhD}$ was set:

- Determination of whether Asc is required or not as a co-factor of CrVDE and the general role of Asc in the NPQ induction. 



\section{3.) MATERIALS AND METHODS}

3.1) Regulation of Asc biosynthesis and its physiological importance in $C$. reinhardtii

\subsection{1) Algal strains and growth conditions}

Chlamydomonas reinhardtii strain cw15-325 (cwd $\left.\mathrm{mt}^{+} \arg 7 \mathrm{nit}^{+} \mathrm{nit}^{+}\right)$and its $A R G 7$ complemented control strain (cw15-412, obtained by transformation with the $A R G 7$ containing plasmid pCB412) were provided by Dr. Michael Schroda (Technische Universität Kaiserslautern, Germany). The strain cw15-325 was used as recipient strain for transformation with VTC2-amiRNA and Empty vector control constructs. The pgrll mutant and the CC-124 strain were provided by Dr. Gilles Peltier (CEA Cadarache, France).

Strains were grown mixotrophically in Tris-acetate-phosphate (TAP) medium on a rotatory shaker at $22^{\circ} \mathrm{C}$ at $80 \mu$ mole photons $\mathrm{m}^{-2} \mathrm{~s}^{-1}$. The cw15-325 strain is auxotrophic for arginine, therefore its TAP medium was supplemented with 100 $\mu \mathrm{g} / \mathrm{ml}$ of L-arginine. For physiological analyses, precultures were grown in $25-\mathrm{ml}$ Erlenmeyer flasks for three days, after which the cells were transferred to 250-ml Erlenmeyer flasks, with an initial cell density of 1 million cells $/ \mathrm{ml}$ and the cultures were grown for two additional days.

For growing the cells in light-dark cycles, a Multi-Cultivator MC 1000-OD instrument (Photon Systems Instruments, Brno, Czech Republic) was used. At the start of cultivation, the chl content was set to $0.5 \mu \mathrm{g} \mathrm{Chl}(\mathrm{a}+\mathrm{b}) / \mathrm{ml}$ (Porra et al., 1989). The cells were grown at $22^{\circ} \mathrm{C}, 80 \mu$ mole photons $\mathrm{m}^{-2} \mathrm{~s}^{-1}$ at $10 \mathrm{~h}$ light/14 h dark cycles for four days and in continuous light for two additional days.

\subsection{2) amiRNA design and transformation}

The amiRNAs targeting the $C$. reinhardtii VTC2 locus were designed according to Molnar et al., 2009 using the WMD2 tool at http://wmd2.weigelworld.org (Ossowski et al., 2008). One amiRNA targeting the coding region (CDS, denoted as VTC2-A strains) and containing three mismatches relative to $V T C 2$, and one amiRNA targeting the 3'UTR of VTC2 (denoted as VTC2$B$ strains) and containing one mismatch were selected. The constructs contained one 
mismatch at position 5 relative to their amiRNA* sequence (Table 1). The synthesized sense and antisense oligonucleotides with SpeI-compatible ends were annealed by boiling and slowly cooling down and ligated into the SpeI-digested vector pChlamiRNA2 (Molnar et al., 2009). Screening for correct clones was done as described previously (Molnar et al., 2009). The plasmid was linearized by digestion with HindIII and transformed into cw15-325 by vortexing with glass beads (Kindle, 1990). The arginine prototrophic transformants were maintained on TAP plates under low light (approximately $2 \mu$ mole photons $\mathrm{m}^{-2} \mathrm{~s}^{-1}$ ) in order to minimize stress effects.

\begin{tabular}{|c|c|c|c|}
\hline Name & Target Sequence in $V T C 2$ & $\begin{array}{l}\text { Sense Sequence } \\
\left(5^{\prime}->3^{\prime}\right)\end{array}$ & $\begin{array}{c}\text { Antisense Sequence } \\
\left(5^{\prime}->3^{\prime}\right)\end{array}$ \\
\hline $\begin{array}{l}\text { amiRNA- } \\
\text { vtc2-a }\end{array}$ & $\begin{array}{l}\underline{\underline{G}} \text { GGTGCGGAGGACTTT } \\
\text { GCCT } \underline{\underline{T}}\end{array}$ & $\begin{array}{l}\text { ctagtTCGTGCGTAGGA } \\
\text { CTTTCCCTAtctcgctgatc } \\
\text { ggcaccatgggggtggtggtgatca } \\
\text { gcgctaTAGGCAAAGTCC } \\
\text { TACGCACGAg }\end{array}$ & $\begin{array}{l}\text { ctagcTCGTGCGTAGGA } \\
\text { CTTTGCCTAtagegctgatc } \\
\text { accaccaccccatggtgccgatca } \\
\text { gcgagaTAGGGAAAGTC } \\
\text { CTACGCACGAa }\end{array}$ \\
\hline $\begin{array}{l}\text { amiRNA- } \\
\text { vtc2-b }\end{array}$ & $\begin{array}{l}\text { GTGAGGGGCATTAATT } \\
\text { GTCAG }\end{array}$ & $\begin{array}{l}\text { ctagtGTGAGGGGCATT } \\
\text { AATTCTCAAtctcgctgatc } \\
\text { ggcaccatgggggtggtggtgatca } \\
\text { gcgctaTTGACAATTAAT } \\
\text { GCCCCTCACg }\end{array}$ & $\begin{array}{l}\text { ctagcGTGAGGGGCATT } \\
\text { AATTGTCAAtagcgctgatc } \\
\text { accaccacccccatggtgccgatca } \\
\text { gcgagaTTGAGAATTAA } \\
\text { TGCCCCTCACa }\end{array}$ \\
\hline
\end{tabular}

Table 1. Oligonucleotide primers for generating the amiRNA constructs

\subsection{3) Analysis of gene expressions}

For RNA isolation, approximately 30 million cells were collected and the Direct-Zol RNA kit was used, following the recommendation of the manufacturer (ZymoResearch). RNA integrity was checked on a 1\% (w/v) denaturing agarose gel. To remove contaminating DNA from the samples, the isolated RNA was treated with DNaseI (ZymoResearch).

Northern blot hybridizations with $(\alpha-32 \mathrm{P})$ radiolabeled probes specific for VTC2 and Actin (derived from amplified cDNA sequences) were performed as described previously (Ausubel et al., 2001). The complete VTC2 cDNA was amplified with the forward primer ATTCTCTTCAGGCGCTGCTT and the reverse primer ACCGCTCCTCGCTCAACGAC (product size 1813 nt); Actin cDNA was amplified with the forward primer GATCTGGCACCACACCTTCT and the reverse primer CATCTCCTGCTCGAAGTCCA (product size $430 \mathrm{nt}$ ).

Primers for real-time qPCR analysis were designed using the NCBI Primer Blast Tool (http://www.ncbi.nlm.nih.gov/tools/primer-blast/). The melting temperature was set to $60^{\circ} \mathrm{C}$, the amplicon length was set between 100 and $130 \mathrm{bp}$ 
(Table 2). Reverse transcription was primed with oligo dT using $2 \mu \mathrm{g}$ of total RNA and SuperScript III reverse transcriptase (Life Technologies). To confirm the absence of DNA contaminations, an aliquot of the RNA sample was used without reverse transcriptase. Real-time qPCR analysis was performed using an Applied Biosystems Prism 7900HT Fast Real Time PCR System using Absolute SYBR Green ROX Mix (Thermo Scientific). To ensure correct normalization of the investigated genes, we tested the expression levels of 12 potential reference genes. The three reference genes showing the most stable expression in the control and the Asc-deficient strains were bTub2 (Cre12.g549550), actin (Cre13.g603700) and UBQ (XP_001694320); the data are presented as fold-change in mRNA transcript abundance, normalized to the average of the three reference genes, and relative to the EV2 control sample. Real-time qPCR analysis was carried out with three technical replicates for each sample and two or three biological replicates were measured; the standard error was calculated based on the different transcript abundances amongst the independent biological replicates.

\begin{tabular}{|c|c|c|c|}
\hline Name & Protein ID & Forward Sequence & Reverse Sequence \\
\hline bTub2 & Cre12.g549550 & ACTGGCTGTGATTGTGCTTCAGG & TGTCTGCTGCTGCACCTTTACG \\
\hline Actin & Cre13.g603700 & GCGGCTAACGACGGAGGAT & CCATGACCCGCTCCTCATATC \\
\hline UBQ & XP_001694320 & GCGATTTCTCGTTGGGCAGT & TGGCCCATCCACTTGTCCTT \\
\hline VTC2 & Cre13.g588150 & TGCTAAAGCTGCTGCCGACATTG & CACTGAGACACGTCGTACCTGAAC \\
\hline SNE1 & Cre01.g019250 & GAGTTCTGCCACGAGTTCCA & TGGTTGGACTGGATGAAGCC \\
\hline INM1 & Cre02.g109600 & AGAGTTTACGGACGTGTGCC & TGAGCCGGTACTCCCAGTAG \\
\hline GalDH & Cre14.g630400 & CTACTACGGCGCCACTCG & TCCACATTCAGGCCATAGCG \\
\hline ROC15 & AB363964 & CAGGAGATGAACATTGACGGC & TGGTGCCGGTCACGTC \\
\hline
\end{tabular}

Table 2. Oligonucleotide primers for $q R T-P C R$ analysis to assess the expression of certain genes involved in Asc metabolism.

\subsection{4) Determination of cell size and cell density}

The cell density was determined either by a Beckman Coulter Z2 instrument or a Millipore Scepter ${ }^{\mathrm{TM}} 2.0$ hand-held cell counter, which also allows a precise determination of cell sizes. Cellular Asc and $\mathrm{H}_{2} \mathrm{O}_{2}$ concentrations were calculated by taking these values into account (Kovács et al., 2016).

\subsection{5) Light and chemical treatments}

For $\mathrm{H}_{2} \mathrm{O}_{2}$ treatments, cultures were grown until the mid-exponential phase and the cell density was adjusted to 3 million cells $/ \mathrm{ml}$. Based on preliminary 
experiments, we added $1.5 \mathrm{mM} \mathrm{H}_{2} \mathrm{O}_{2}$ (Sigma Aldrich) to the cultures, and the presented measurements were carried out after 7 and $23 \mathrm{~h}$.

For high-light treatment, the cultures were placed at high light $(530 \mu$ mole photon $\mathrm{m}^{-2} \mathrm{~s}^{-1}$ ) for $16 \mathrm{~h}$. For dark-light-shift experiments, cultures (2.5 million cells/ml) were dark-adapted overnight (about $14 \mathrm{~h}$ darkness) on a rotatory shaker and then illuminated with $80 \mu$ mole photons $\mathrm{m}^{-2} \mathrm{~s}^{-1}$. For Rose Bengal $(4,5,6,7-$ tetrachloro-3',6'-dihydroxy-2',4',5',7'-tetraiodo-3H-spiro[isobenzofuran-1,9'xanthen]-3-one, RB) and 3-(3',4'-dichlorophenyl)-1,1-dimethylurea (DCMU) treatments, cultures ( 3 million cells/ml) were supplemented with $5 \mu \mathrm{M} \mathrm{RB}$ and/or $100 \mu \mathrm{M}$ DCMU. For Asc supplementation experiments, 0.1, 0.5, and $2 \mathrm{mM} \mathrm{Na-Asc}$ (Roth $\mathrm{GmbH}$ ) was added to the cultures, and measurements were carried out $4 \mathrm{~h}$ after Asc addition, unless stated otherwise. In one set of experiments, a $2 \mathrm{mM} \mathrm{Na-Asc}$ treatment was done in combination with catalase $(5 \mu \mathrm{g} / \mathrm{ml}$, catalase from bovine liver, Sigma Aldrich).

\subsection{6) Ascorbate content determination by HPLC}

Twenty million cells were collected by centrifugation, washed once with distilled water, and the Asc was extracted by re-suspending the cells in $200 \mu 1$ of extraction buffer (2 mM EDTA, $5 \mathrm{mM}$ 1,4-Dithiothreitol, $5 \%$ orthophosphoric acid). In most cases, 1,4-Dithiothreitol was added to the extraction buffer to stabilize Asc. In an experiment to determine the DHA content of the samples, 1,4-Dithiothreitol was omitted, but the samples were processed and measured immediately. After adding the extraction buffer, the samples were vortexed vigorously with glass beads (Sigma, 212-300 $\mu \mathrm{m}$ ) for $30 \mathrm{~s}$. This was followed by centrifugation at $11500 \mathrm{~g}, 4^{\circ} \mathrm{C}$, for $30 \mathrm{~min}$ and the supernatant was collected.

Quantification of Asc was performed by HPLC using a Shimadzu Prominence HPLC system with a Nexera X2diode array detection unit (Shimadzu, Kyoto, Japan) set to $244 \mathrm{~nm}$. The Asc content was quantified using standards. For all separations, a Phenomenex Synergi Hydro-RP 250 x $4.6 \mathrm{~mm}$ column was used with a particle size of $4 \mu \mathrm{m}$ and a pore size of $80 \AA$. HPLC runs were performed using $100 \%$ solvent $\mathrm{A}\left(50 \mathrm{mM} \mathrm{KH} \mathrm{PO}_{4}, \mathrm{pH} 2.5\right)$ for $3.5 \mathrm{~min}$, followed by $5.5 \mathrm{~min}$ using $70 \%$ solvent $\mathrm{A}$ and $30 \%$ acetonitrile, and additional 8 min using $100 \%$ solvent $\mathrm{A}$, with a flow rate of $1 \mathrm{ml} / \mathrm{min}$. The column was kept at $20^{\circ} \mathrm{C}$ and the samples were 
stored at $4^{\circ} \mathrm{C}$. Cellular Asc contents were calculated based on cell numbers and determined cell sizes (Kovács et al., 2016)).

\subsection{7) Metabolite profiling using GC-MS}

Twenty million $C$. reinhardtii cells were collected by vacuum filtering through a hydrophilic polyvinylidene fluoride membrane $(25 \mathrm{~mm}$ diameter, $0.45 \mu \mathrm{m}$ pore size, HVLP02500, Merck Millipore). The filters were put in $1.5 \mathrm{ml}$ tubes, immediately frozen in liquid nitrogen, and stored at $-80^{\circ} \mathrm{C}$ until extraction. The filtration process took around 1 min per sample.

Extraction and derivatization was done according to the literature (Mettler et al., 2014) with modifications. Extraction was started by adding $900 \mu 1$ methanol:chloroform (7:3, v:v) mixture cooled to $-20^{\circ} \mathrm{C}$ and containing $0.2 \mathrm{mg} / \mathrm{ml}$ of ribitol added as internal standard to the frozen sample. After vigorous vortexing, samples were subjected to two freeze-thaw cycles. A 5-min sonication cold bath treatment was followed by $1 \mathrm{~h}$ incubation at $4^{\circ} \mathrm{C}$ with shaking. The filter was then carefully removed and $450 \mu \mathrm{l}$ of ice cold water added. After centrifugation for $5 \mathrm{~min}$ at maximum speed at $4^{\circ} \mathrm{C}, 500 \mu \mathrm{l}$ of the upper methanol-water phase was transferred to a new tube and concentrated to dryness in a SpeedVac system overnight. Dry extracts were flushed with argon and stored at $-80^{\circ} \mathrm{C}$ before derivatization.

Derivatization of metabolites was done by adding $20 \mu \mathrm{l}$ of methoxyamine hydrochloride $\left(20 \mathrm{mg} / \mathrm{mL}\right.$ in pyridine) and incubation at $30^{\circ} \mathrm{C}$ for $90 \mathrm{~min}$ with shaking. Next, $40 \mu \mathrm{l}$ of $\mathrm{N}$-methyl-N-(trimethylsilyl) trifluoroacetamide containing 20 $\mu 1 / \mathrm{ml}$ of FAMES (retention time standard mixture of fatty acid methylesters; 0.22 $\mathrm{mg} / \mathrm{ml}$ in pyridine) were added followed by another incubation for $30 \mathrm{~min}$ at $37^{\circ} \mathrm{C}$ with shaking. Samples were centrifuged for $5 \mathrm{~min}$ at full speed, and $50 \mu \mathrm{l}$ of the supernatant was transferred into GC vials. A volume of $1 \mu \mathrm{l}$ of this solution was used for injection. The GC-MS system comprised an Agilent 6890N gas chromatograph, a CTC CombiPAL autosampler, and a LECO Pegasus III TOF-MS. Metabolites were identified in comparison to database entries of authentic standards (Kopka et al., 2005). Chromatograms and mass spectra were evaluated using the Chroma TOF 1.0 (Leco) and TagFinder 4.0 software (Luedemann et al., 2008). 


\subsection{8) Electron transport measurements}

Chlorophyll $a$ fluorescence and light-induced absorbance changes at $830 \mathrm{~nm}$ reflecting changes in the redox states of $\mathrm{P}_{700}$ and $\mathrm{PC}$ of intact cells were measured using a Dual-PAM-100 instrument (Heinz Walz GmbH, Germany). C. reinhardtii cells were dark-adapted for $15 \mathrm{~min}$ and then $30 \mu \mathrm{g} \mathrm{Chl}(\mathrm{a}+\mathrm{b})$ in total were filtered onto a Whatman glass microfibre filter $(\mathrm{GF} / \mathrm{B})$ that was placed in between two microscopy cover slips with a spacer. For the determination of ETR(II) and ETR(I), the intensity of the saturating pulses was $3000 \mu$ mole photons $\mathrm{m}^{-2} \mathrm{~s}^{-1}$ and the samples were kept at each light intensity for $3 \mathrm{~min}$; the ETR parameter is calculated based on the formula $E T R=P A R \times f \times A b s \times Y_{I I}$, where $P A R$ is the incident photon flux density, $f$ is the distribution of absorbed PAR to PSII (typically 0.5), Abs is PAR-absorptivity (typically 0.84 ), and $Y_{I I}$ is the measured effective PSII quantum yield.

\subsection{9) $\mathrm{H}_{2} \mathrm{O}_{2}$ content determination}

$\mathrm{H}_{2} \mathrm{O}_{2}$ content was measured using the Amplex Red Hydrogen Peroxide/Peroxidase Assay Kit (Thermo Fisher Scientific, A22188). 20 million $C$. reinhardtii cells were collected by centrifugation and the pellet was homogenized in $0.1 \%$ trichloroacetic acid using glass beads and quartz sand. The broken cells were centrifuged, and the supernatant was then used to measure the $\mathrm{H}_{2} \mathrm{O}_{2}$ content. The supernatant was supplemented with $25 \mathrm{mM}$ potassium phosphate buffer $(\mathrm{pH} 8.0), 0.1$ units $\mathrm{ml}^{-1}$ horseradish peroxidase and $50 \mu \mathrm{M}$ Amplex Red reagent and incubated at $25^{\circ} \mathrm{C}$ for $30 \mathrm{~min}$. The accumulation of resorufin was determined fluorometrically at 565/580 nm (Thermo Scientific, Fluoroskan Ascent FL). The cellular $\mathrm{H}_{2} \mathrm{O}_{2}$ content was calculated based on standard curve, cell numbers and cell sizes (Kovács et al., 2016).

\subsubsection{0) Statistics}

The presented data are based on at least three independent experiments. When applicable, averages and standard errors $( \pm$ SEM $)$ were calculated. Statistical significance was analyzed using Student's t-test and the significance levels are presented when applicable. 
3.2) Determination of the role of Asc in the inactivation of PSII during sulphur deprivation-induced $\mathrm{H}_{2}$ production in $C$. reinhardtii

\subsection{1) Algal growth conditions and sulphur deprivation}

Chlamydomonas reinhardtii CC-124 cultures were grown in TAP medium with a light intensity of $100 \mu \mathrm{mol}$ photons $\mathrm{m}^{-2} \mathrm{~s}^{-1}$ at $21-23^{\circ} \mathrm{C}$ in an algal growth chamber. The $250-\mathrm{ml}$ flasks containing $50 \mathrm{ml}$ of TAP medium were shaken at 120 rpm, and the cultures were grown for 3 days in sulphur-containing medium.

After 3 days of cultivation, the cells were washed five times with sulphur-free TAP medium (centrifugation at $1000 \mathrm{~g}$, at $18^{\circ} \mathrm{C}$ for $5 \mathrm{~min}$ ). For the $\mathrm{H}_{2}$ production experiments the Chl content was set at $20 \mu \mathrm{g} \mathrm{Chl(a+b)/ml} \mathrm{(Porra} \mathrm{et} \mathrm{al.,} \mathrm{1989),} \mathrm{and} 30$ $\mathrm{ml}$ of culture in sulphur-free TAP medium were placed into $125-\mathrm{ml}$ serum vials and sealed off with rubber septa. All steps were carried out under sterile conditions. The gas phase of the bottle was flushed with $\mathrm{N}_{2}$ gas for $10 \mathrm{~min}$ and the cultures were kept in the algal growth chamber, under the same conditions as indicated above.

\subsection{2) Analysis of gene expressions}

For RNA isolation, $1 \mathrm{ml}$ of culture was collected, and the protocol was performed as above (see chapter 3.1.3). The primer pairs for the target genes used in the real-time qPCR analysis can be found in Table 3.

The data are presented as fold-change in mRNA transcript abundance of the target gene, normalized to the average of the three reference genes, and relative to the control sample (cultures grown in TAP medium under normal growth conditions). Real-time qPCR analysis was carried out with three technical replicates for each sample and three biological replicates were measured; the standard error was calculated based on the range of fold-change by calculating the minimum and the maximum of the fold-change using the standard deviations of $\Delta \Delta \mathrm{C}_{\mathrm{t}}$. 


\begin{tabular}{|c|c|c|c|}
\hline Name & Protein ID & Forward Primer Sequence & Reverse Primer Sequence \\
\hline bTub2 & Cre12.g549550 & ACTGGCTGTGATTGTGCTTCAGG & TGTCTGCTGCTGCACCTTTACG \\
\hline Actin & Cre13.g603700 & GCGGCTAACGACGGAGGAT & CCATGACCCGCTCCTCATATC \\
\hline$U B Q$ & XP_001694320 & GCGATTTCTCGTTGGGCAGT & TGGCCCATCCACTTGTCCTT \\
\hline$V T C 2$ & Cre13.g588150 & TGCTAAAGCTGCTGCCGACATTG & CACTGAGACACGTCGTACCTGAAC \\
\hline HYDA1 & Cre03.g199800 & GGCGAGTGGGACAATCCAAT & TGCCCGTGAACAGCTCATAG \\
\hline APX1 & Cre02.g087700 & TGGACTCATGGTTGCTGGAC & CTGCCAGGCTTGACTCATCA \\
\hline GPXH & Cre10.g458450 & GCGGTCGCCAATAACCAAT & AAGGGCTGTCCCGAAAGC \\
\hline GSTS1 & Cre16.g688550 & CAGAGGTGAAAGGCGGATAC & GTGTTGCAATGGACTTCAGC \\
\hline FSD1 & Cre10.g436050 & CCGTGGTGGAGGGCAAGACCCCCAT & TCGCCTGGCGCCGACATGCTTGTGA \\
\hline HSP70A & Cre08.g372100 & GCCAAGAACCAGGTCGCTAT & CCTGGAAAGGCCACAGCTTA \\
\hline
\end{tabular}

Table 3. Oligonucleotide primers for $q R T$-PCR analysis to assess the expression of oxidative stress responsive genes.

\subsection{3) Western blot analysis and protein content determination}

At each time point, $1 \mathrm{ml}$ of culture was collected, spun-down for removal of the supernatant and frozen in liquid nitrogen. The samples were then solubilized with $370 \mu \mathrm{l}$ of protein extraction buffer $(50 \mathrm{mM}$ Tris/ $\mathrm{HCl}, \mathrm{pH} 8.3,0.25 \%$ Triton $\mathrm{X}-100,1$ $\mathrm{mM}$ 1,4-Dithiothreitol and Roche cOmplete Protease Inhibitor Cocktail), sonicated for $30 \mathrm{sec}$, incubated in the dark at $4^{\circ} \mathrm{C}$ for $30 \mathrm{~min}$ with vigorous shaking, and then centrifuged at $4700 \mathrm{~g}$ for $4 \mathrm{~min}$ at $4^{\circ} \mathrm{C}$. The supernatant was collected into a new Eppendorf tube and the $\mathrm{Chl}$ and the protein content of the extract was determined (using the Bio-Rad Protein Assay Kit, according to the recommendations of the manufacturer. A quantity equivalent to $2 \mu \mathrm{g} \mathrm{Chl}(\mathrm{a}+\mathrm{b})$ was then mixed with double strength Laemmli buffer and incubated at $75^{\circ} \mathrm{C}$ for $10 \mathrm{~min}$ before loading onto the gel. Proteins separated by SDS-PAGE (Peqlab Perfect Blue Twin Gel System) were transferred to a polyvinylidene difluoride membrane (Hybond P) using a tank blotting system (Cleaver Scientific Ltd). Specific polyclonal antibodies (produced in rabbits) against HydA, PetB, PsbA, PsaA, PSBO, CP43 and RbcL were purchased from Agrisera AB. As secondary antibody, a goat anti-rabbit IgG horseradish peroxidase conjugate was used (Bio-Rad). Immunochemical detection was carried out with the ECL Prime System (GE Healthcare), according to the instructions of the manufacturer.

\subsection{4) Determination of cell size and cell density}

The cell density was determined by a Scepter ${ }^{\mathrm{TM}} 2.0$ hand-held cell counter (Millipore), as described above (see chapter 3.1.4). 


\subsection{5) Element determination}

An algal sample of $30 \mathrm{mg}$ dry weight was digested with $10 \mathrm{ml} 67 \% \mathrm{HNO}_{3}$ in a microwave sample preparation system (Anton Paar). After digestion, the sample was diluted to $20 \mathrm{ml}$ with high-purity water (1/8.2 M $\Omega$ ) in which the concentration of various elements ( $\mathrm{Ca}, \mathrm{Cu}, \mathrm{Fe}, \mathrm{K}, \mathrm{Mg}, \mathrm{Mn}, \mathrm{P}, \mathrm{S}$, and $\mathrm{Zn}$ ) was determined by ICP-OES (Spectro Genesis), according to the literature (Szentmihályi et al., 2015). S, P and multi-element standards were used (CPAchem) for standardization and the calculation of concentrations.

\subsection{6) Ascorbate content determination}

The Asc content was determined as above (see chapter 3.1.6).

\subsection{7) Thylakoid isolation}

Chlamydomonas cell culture equivalent to $1.2 \mathrm{mg} \mathrm{Chl}(\mathrm{a}+\mathrm{b})$ were distributed into four $15-\mathrm{ml}$ centrifuge tubes and spun down at $2990 \mathrm{~g}$ for $3 \mathrm{~min}$. The pelleted cells were resuspended in $200 \mu$ of homogenisation buffer (50 mM Tricine, $\mathrm{pH} 7.8$, $5 \mathrm{mM} \mathrm{MgCl}_{2}$ and $10 \mathrm{mM} \mathrm{NaCl}$, supplemented with $0.1 \%$ BSA prior to isolation). The suspensions were transferred to $1.5 \mathrm{ml}$ microcentrifuge tubes and $200 \mu \mathrm{l}$ of glass beads, $212-300 \mu \mathrm{m}$ in diameter, were added into each tube. The cells were ground by Bullet blender Gold cell disruptor (Next Advance, Inc.) at maximum speed for 10 $\min$ at $4^{\circ} \mathrm{C}$. The glass beads were washed three times by $1 \mathrm{ml}$ homogenization buffer. The pooled samples were centrifuged at $2990 \mathrm{~g}$ for $3 \mathrm{~min}$ at $4^{\circ} \mathrm{C}$. The supernatant was diluted to $50 \mathrm{ml}$ with homogenization buffer, and was centrifuged at $30000 \mathrm{~g}$ for $10 \mathrm{~min}$ at $4^{\circ} \mathrm{C}$. The pellet was resuspended in $250 \mu \mathrm{l}$ homogenization buffer without BSA. The isolated thylakoid membranes were frozen in liquid $\mathrm{N}_{2}$ and stored at $-80^{\circ} \mathrm{C}$ until use.

\subsection{8) Measurement of electron transport activity}

The photosynthetic electron transport rate of isolated thylakoid membrane was measured as oxygen uptake in the presence of methylviologen (MV), an artificial electron acceptor of PSI (Izawa, 1980), using a Clark-type oxygen electrode (Hansatech Instruments). The isolated thylakoid membranes were diluted to $50 \mu \mathrm{g}$ $\mathrm{Chl}(\mathrm{a}+\mathrm{b}) / \mathrm{ml}$ in homogenization buffer, and $100 \mu \mathrm{M} \mathrm{MV}$ and $2 \mathrm{mM}$ sodium azide 
were added prior to the measurement. To assess the photosynthetic activity of PSII reaction centers with impaired OECs, besides $\mathrm{MV}$ and sodium azide, $2 \mathrm{mM}$ of diphenylcarbazide (DPC) were added as an exogenous electron donor. A 1-ml volume of sample was illuminated with white light from a halogen cold-light source (Schott AG KL2500 LCD) at a photon flux density of $500 \mu \mathrm{mol} \mathrm{m}^{-2} \mathrm{~s}^{-1}$ at ambient temperature for $6 \mathrm{~min}$, and the slope of the oxygen uptake curve was determined by linear fitting. Net DPC-dependent photosynthetic activity was calculated based on the difference in oxygen uptake rates measured in the presence or absence of DPC.

\subsection{9) Thermoluminescence measurements}

Thermoluminescence measurements were carried out using a custom-made apparatus, similar to the one described in the literature (Ducruet and Vass, 2009). The cell suspension [300 $\mu \mathrm{l}, 20 \mu \mathrm{g} \mathrm{Chl}(\mathrm{a}+\mathrm{b}) / \mathrm{ml}]$ was placed on a copper sample holder, connected to a cold finger immersed in liquid $\mathrm{N}_{2}$. A heater coil (Thermocoax SEI 10/50), placed under the sample holder, ensured the desired temperature of the sample during the measurement. Dark-adapted samples were illuminated at $4{ }^{\circ} \mathrm{C}$ with a single-turnover flash provided by a stroboslave, and the sample was heated to $70^{\circ} \mathrm{C}$ in darkness with a heating rate of $20^{\circ} \mathrm{C} / \mathrm{min}$. The emitted thermoluminescence was measured with an end-window photomultiplier (Hamamatsu H10721-20) simultaneously with recording the temperature. When applicable, $20 \mathrm{mM}$ Asc was added to the samples 30 min prior to the measurements.

\subsubsection{0) Statistics}

The statistical analysis was performed as above (see chapter 3.1.10). 


\section{3) Determination of the role of Asc in the induction of NPQ}

\subsection{1) Algal strains and growth conditions}

Chlamydomonas reinhardtii strains CC-4533, LMJ.RY0402.058624 and LMJ.RY0402.146784 were obtained from the CLiP library (Li et al., 2016a) and streaked into single colonies. The 137AH strain and the NPQ1, NPQ4, and stt7 mutants were obtained from the Chlamydomonas Resource Center (https://www.chlamycollection.org/).

Strains were grown mixotrophically (in TAP medium) or autotrophically (in High salt minimal (HSM) medium) on a rotatory shaker at $22^{\circ} \mathrm{C}$ at $100 \mu$ mole photons $\mathrm{m}^{-2} \mathrm{~s}^{-1}$ when required. For physiological analyses, precultures were grown in 25-ml Erlenmeyer flasks for three days, after which the cells were transferred to 250-ml Erlenmeyer flasks, with an initial cell density of 1 million cells/ml and the cultures were grown for two additional days.

\subsection{2) DNA Isolation and PCR}

Total genomic DNA from $C$. reinhardtii strains $\mathrm{CC}-4533$ and LMJ.RY0402.058624 was extracted according to published protocols (Barahimipour et al., 2015; Schroda et al., 2001), and $2 \mu \mathrm{l}$ of the extracted DNA were used as template for the PCR assays.

To confirm that the LMJ.RY0402.058624 strain was unable to amplify the complete VTC2 gene, PCR assays were conducted using primer pairs that amplify sequences upstream and downstream of the predicted site of the cassette insertion. The primers 5'-TGATGGCCAAGGGCTTAGTG-3' and 5-CCGCAAACACCATGCAATCT-3' amplified the region of the gene before the predicted site of insertion (control amplicon, with an expected size of $750 \mathrm{bp}$ ), and the primers 5'-AGATTGCATGGTGTTTGCGG-3' and 5'-ATCTCAAACGATGCCGGGTT-3' amplified the portion of the gene predicted to be interrupted by the cassette insertion (target amplicon, with an expected size of $1100 \mathrm{bp})$. 


\subsection{3) Analyses of gene expressions}

Sample collection and RNA isolation was performed as above (see chapter 3.1.3). The primer pairs for the target genes used in the real-time qPCR analysis can be found in Table 2.

The data are presented as fold-change in mRNA transcript abundance of the target gene, normalized to the average of the three reference genes, and relative to the untreated CC-4533 strain. Real-time qPCR analysis was carried out with three technical replicates for each sample and three biological replicates were measured; the standard error was calculated based on the range of fold-change by calculating the minimum and the maximum of the fold-change using the standard deviations of $\Delta \Delta \mathrm{Ct}$.

\subsection{4) Light and chemical treatments}

For $\mathrm{H}_{2} \mathrm{O}_{2}$ treatments during the cell characterization, cultures were grown until the mid-exponential phase and the cell density was adjusted to 3 million cells $/ \mathrm{ml}$. Based on preliminary experiments, we added $1.5 \mathrm{mM} \mathrm{H}_{2} \mathrm{O}_{2}$ (Sigma Aldrich) to the cultures, and the presented measurements were carried out after $7 \mathrm{~h}$.

For high-light treatment, the cultures were placed at high light $(530 \mu$ mole photon $\mathrm{m}^{-2} \mathrm{~s}^{-1}$ ) for $16 \mathrm{~h}$. For Asc supplementation experiments, $1 \mathrm{mM} \mathrm{Na-Asc} \mathrm{(Roth}$ $\mathrm{GmbH}$ ) was added to the cultures, and measurements were carried out $2 \mathrm{~h}$ after Asc addition. For the experiments related to the effect of $\mathrm{H}_{2} \mathrm{O}_{2}$ in NPQ induction, $1.5 \mathrm{mM}$ $\mathrm{H}_{2} \mathrm{O}_{2}$ or catalase ( $5 \mu \mathrm{g} / \mathrm{ml}$, catalase from bovine liver, Sigma Aldrich) were added to the cells after a 30-min dark adaptation and the measurements were carried out after a $2 \mathrm{~h}$ incubation period in the dark with shaking.

\subsection{5) Electron transport measurements}

Chlorophyll $a$ fluorescence and light-induced absorbance changes at $830 \mathrm{~nm}$ reflecting changes in the redox states of P700 and PC of intact cells were measured using a Dual-PAM-100 instrument (Heinz Walz GmbH, Germany). C. reinhardtii cells were dark-adapted for $30 \mathrm{~min}$ and then $30 \mu \mathrm{g} \mathrm{Chl}(\mathrm{a}+\mathrm{b})$ in total were filtered onto a Whatman glass microfibre filter $(\mathrm{GF} / \mathrm{B})$ that was placed in between two microscopy cover slips with a spacer. For the determination of ETR(II), the intensity of the saturating pulses was $3000 \mu$ mole photons $\mathrm{m}^{-2} \mathrm{~s}^{-1}$ and the samples were kept at each light intensity for $3 \mathrm{~min}$. For NPQ induction protocol, the light adaptation 
consisted of $30 \mathrm{~min}$ illumination at $530 \mu$ mole photons $\mathrm{m}^{-2} \mathrm{~s}^{-1}$, followed by $12 \mathrm{~min}$ of dark adaptation.

\subsection{6) Chl $a$ fluorescence measurements}

Chl $a$ fluorescence measurements were carried out at room temperature between $21^{\circ} \mathrm{C}$ with a Handy-PEA instrument (Hansatech Instruments Ltd). Cultures of $C$. reinhardtii were dark-adapted for $15 \mathrm{~min}$ and then $30 \mu \mathrm{g} \mathrm{Chl} / \mathrm{ml}$ were filtered onto a Whatman glass microfibre filter (GF/B) that was placed in a Handy-PEA leaf clip. The algal sample was illuminated with continuous red light $(3500 \mu \mathrm{mol}$ photons $\mathrm{m}^{-2} \mathrm{~s}^{-1}, 650-\mathrm{nm}$ peak wavelength; spectral half-width of $22 \mathrm{~nm}$; light emitted by the LEDs is cut off at $700 \mathrm{~nm}$ by an NIR short-pass filter). The light was provided by an array of three light-emitting diodes focused on a circle of sample surface of $5 \mathrm{~mm}$ in diameter. The first reliably measured point of the fluorescence transient is at $20 \mu \mathrm{s}$, which was taken as $\mathrm{F}_{0}$. The length of the measurements was $5 \mathrm{~s}$.

\subsection{8) Low-temperature fluorescence emission spectra measurements}

A volume equivalent to $2 \mu \mathrm{g} \mathrm{Chl} / \mathrm{ml}$ of culture, collected at different points of the NPQ induction protocol, was filtered onto a Whatman glass microfibre filter (GF/B) that was placed in a holder and immediately frozen in liquid $\mathrm{N}_{2}$. Low-temperature $(77 \mathrm{~K})$ fluorescence emission spectra were measured using a spectrofluorometer (Fluorolog-3/Jobin-Yvon-Spex Instrument S.A., Inc.) equipped with a home-made liquid nitrogen cryostat. The fluorescence emission spectra between 650 and $750 \mathrm{~nm}$ were recorded with an interval of $0.5 \mathrm{~nm}$, using an excitation wavelength of $436 \mathrm{~nm}$ and excitation and emission slits of 5 and $2 \mathrm{~nm}$, respectively. The final spectra were corrected for the photomultiplier's spectral sensitivity.

\subsection{9) Western blot analysis}

The protein isolation and western blot analysis were performed as above (see chapter 3.2.3). Specific polyclonal antibodies (produced in rabbits) against PsaA, PsbA, RbcL, LHCSR3, CP43, PetB, and PSBO were purchased from Agrisera AB. 


\subsubsection{0) Determination of cell size and cell density}

The cell density was determined by a Scepter ${ }^{\mathrm{TM}} 2.0$ hand-held cell counter (Millipore), as described above (see chapter 3.1.4).

\subsubsection{1) Ascorbate content determination}

The Asc content was determined as above (see chapter 3.1.6).

\subsubsection{2) Carotenoid content determination}

A volume equivalent to $30 \mu \mathrm{g} \mathrm{Chl} / \mathrm{ml}$ of culture, collected at different points of the NPQ induction protocol, was filtered onto a Whatman glass microfibre filter (GF/B) immediately frozen in liquid $\mathrm{N}_{2}$ at different points of the NPQ induction protocol. The pigments were extracted by re-suspending the cells in $500 \mu \mathrm{l}$ of ice-cold acetone. After re-suspension, the samples were incubated in the dark for 30 min. This was followed by centrifugation at $11500 \mathrm{~g}, 4^{\circ} \mathrm{C}$, for $10 \mathrm{~min}$ and the supernatant was collected and passed through a PTFE $0.2 \mu \mathrm{m}$ pore size syringe filter.

Quantification of carotenoids was performed by HPLC using a Shimadzu Prominence HPLC system (Shimadzu, Kyoto, Japan) consisting of two LC-20AD pumps, a DGU-20A degasser, a SIL-20AC automatic sample injector, CTO-20AC column thermostat and a Nexera X2 SPD-M30A photodiode-array detector. Chromatographic separations were carried out on a Phenomenex Synergi Hydro-RP $250 \times 4.6 \mathrm{~mm}$ column with a particle size of $4 \mu \mathrm{m}$ and a pore size of $80 \AA .20 \mu \mathrm{l}$ aliquots of acetonic extract was injected to the column and the pigments were eluted by a linear gradient from solvent A (acetonitrile, water, triethylamine, in a ratio of 9:1:0.01) to solvent B (ethylacetate). The gradient from solvent A to solvent B was run from 0 to $25 \mathrm{~min}$ at a flow rate of $1 \mathrm{ml} / \mathrm{min}$. The column temperature was set to $25^{\circ} \mathrm{C}$. Eluates were monitored in a wavelength range of $260 \mathrm{~nm}$ to $750 \mathrm{~nm}$ at a sampling frequency of $1.5625 \mathrm{~Hz}$. Pigments were identified according to their retention time and absorption spectrum and quantified by integrated chromatographic peak area recorded at the wavelength of maximum absorbance for each kind of pigments using the corresponding molar decadic absorption coefficient (Jeffrey et al., 2005).

\subsubsection{3) Statistics}

The statistical analysis was performed as above (see chapter 3.1.10). 


\section{4.) RESULTS}

\section{1) Regulation of Asc biosynthesis and its physiological importance in $C$.}

\section{reinhardtii}

Ascorbate biosynthesis and its regulation are poorly studied in non-vascular plants. It is known that bryophytes and green algae may contain about 100 -fold less Asc than higher plants (Gest et al., 2013; Wheeler et al., 2015). Therefore, the question arises how these organisms can cope with environmental stress conditions if possessing such low Asc contents.

The genome of the model green alga Chlamydomonas reinhardtii encodes all the enzymes of the Smirnoff-Wheeler Asc biosynthesis pathway. Based on gene expression analysis, it was suggested that $C$. reinhardtii GDP-L-galactose phosphorylase, encoded by VTC2 (Cre13.g588150), is a highly regulated enzyme, similarly to higher plants. It is also likely that the Smirnoff-Wheeler pathway represents the only route for providing Asc in algal cells since no evidence was found that other, alternative, pathways could be functional (Urzica et al., 2012).

In order to down-regulate $V T C 2$, with the goal to obtain evidence for its physiological functions and to study the regulation of Asc biosynthesis in $C$. reinhardtii, we used the artificial microRNA (amiRNA) approach which has the advantage that off-target effects and silencing are minimized relative to antisense and inverted repeat constructs (Molnar et al., 2009; Schmollinger et al., 2010).

\subsection{1) Generation of Asc-deficient $C$. reinhardtii strains using an amiRNA}

\section{approach}

For generating VTC2-amiRNA lines, the pChlamiRNA2 vector was used, containing the argininosuccinate lyase (ARG7) gene as selection marker, a strong constitutive promoter (HSP70A-RBCS2) to drive the expression of amiRNAs and a unique SpeI site engineered into the amiRNA precursor to allow easy cloning of the target site-specific oligonucleotides (Figure 7). The WMD tool (http://wmd3.weigelworld.org) was used for the design of the amiRNAs, and one amiRNA targeting the coding region (CDS) and one targeting the 3'UTR of VTC2 mRNA were selected. 


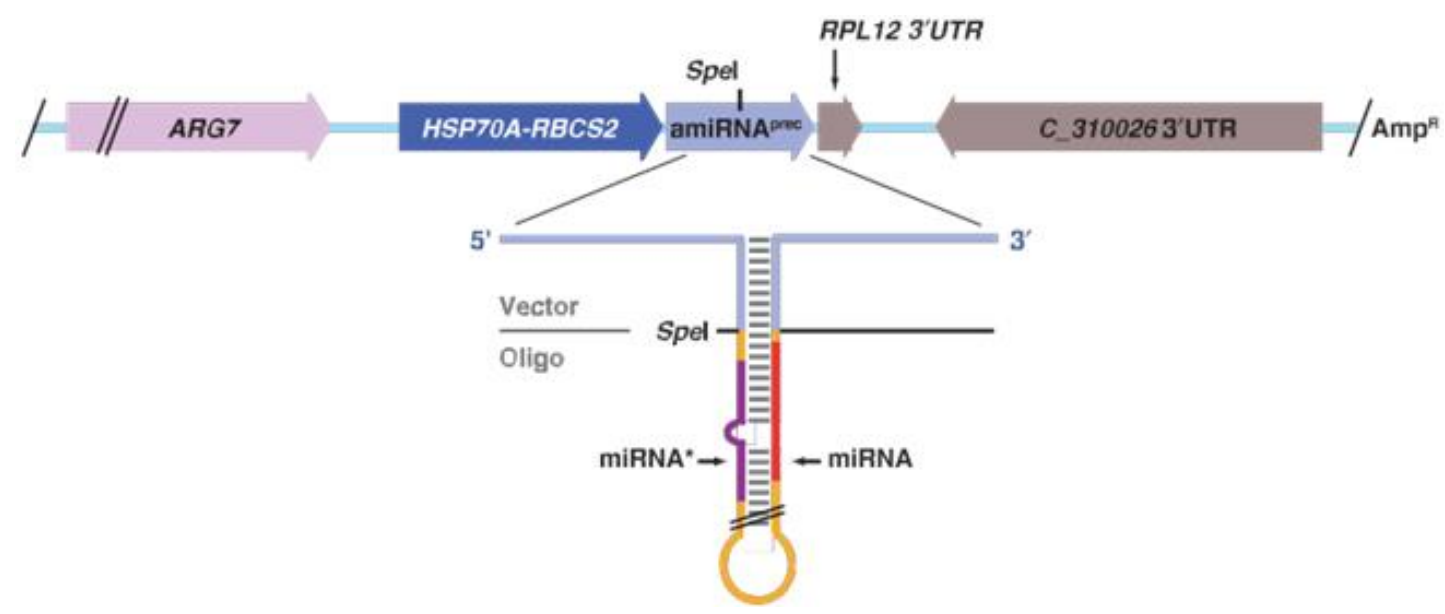

Figure 7. Scheme of the pChlamiRNA2 vector used for the transformation of $C$. reinhardtii using the amiRNA approach. [Source: Chlamydomonas Resource Center - https://www.chlamycollection.org, accessed on 2018.05.17].

We transformed the $C$. reinhardtii cell wall-deficient strain cw15-325 carrying a mutation in the $A R G 7$ with the $V T C 2$-specific amiRNA vectors. In the case of the CDS-targeting amiRNA (VTC2-A) construct, 96 arginine-prototrophic colonies were tested by PCR and 89 of them were found to carry the whole amiRNA cassette. For the VTC2-3'UTR-targeting amiRNA (VTC2-B) construct, 45 out of the 96 tested arginine-prototrophic colonies carried the whole amiRNA cassette. Their Asc content showed a strong reduction; At least $80 \%$ reduction of the parental strain levels was observed. Figure 8 shows the Asc contents of the parental strain (cw15-325), the ARG7-complemented cw15-412 transgenic control strain, several empty vector $(E V)$ transformants as well as the VTC2-A and VTC2-B strains; the $E V$ transformants were generated with the vector containing all the features except the amiRNA-specific fragment, and allowed us to rule out possible effect that would be due to the incorporation of the vector in the $C$. reinhardtii nuclear genome instead of VTC2-deficiency specific effects. For further analysis, we selected two Asc-deficient transformants (VTC2-A27 and VTC2-B27) and an empty vector construct (EV2) as control strain. The inset of Figure shows that the selected VTC2-amiRNA lines are paler compared to the control strains (cw15-325 and EV2) at equal cell densities. 


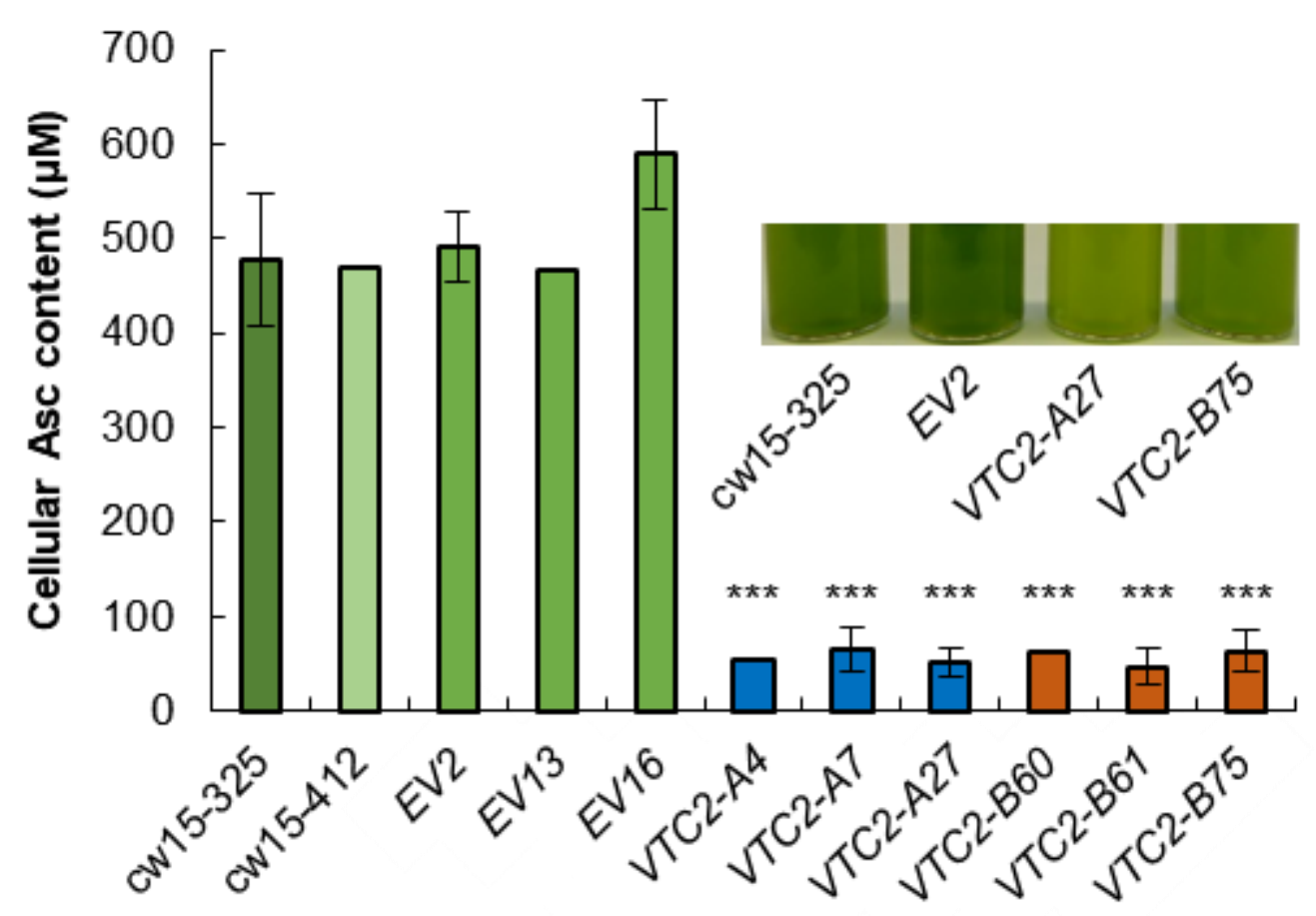

Figure 8. Cellular Asc contents of the parental strain cw15-325, the ARG7complemented control strain (cw15-412), three empty vector controls $(E V)$ and several transgenic strains harbouring amiRNA-VTC2 constructs that target either the coding region (VTC2-A4, A7, A27) or the 3'UTR of VTC2 (VTC2-B60, B61, B75) in $C$. reinhardtii. The cultures were grown under standard growth conditions, at 80 $\mu$ mole photons $\mathrm{m}^{-2} \mathrm{~s}^{-1}$ in TAP medium, until the mid-exponential growth phase. The inset shows the photographs of the cultures at cell densities of 3 million cells $/ \mathrm{ml}$. Mean values $( \pm$ SEM) are each based on 3 biological replicates. Statistical significance levels are presented relative to the cw15-325 strain as: $* * * \mathrm{p}<0.001$.

\subsection{2) The effects of $\mathrm{H}_{2} \mathrm{O}_{2}$ and high light stress on the Asc content and}

\section{VTC2 expression}

We investigated the response of the VTC2-amiRNA lines to $\mathrm{H}_{2} \mathrm{O}_{2}$ treatment, to high light stress, and to the combination of both. C. reinhardtii strains were grown in Tris-acetate phosphate (TAP) medium to mid-exponential phase and the cell density was set to $3 \times 10^{6}$ cells $/ \mathrm{ml}$. The cultures were then challenged with $1.5 \mathrm{mM}$ $\mathrm{H}_{2} \mathrm{O}_{2}$ at a light intensity of about $80 \mu$ mole photon $\mathrm{m}^{-2} \mathrm{~s}^{-1}$ (normal growth light). Samples were taken $7 \mathrm{~h}$ after the addition of $\mathrm{H}_{2} \mathrm{O}_{2}$, because Asc concentration reaches its maximum within 5 to $8 \mathrm{~h}$ (based on preliminary experiments and in agreement with (Urzica et al., 2012)). Figure 9 shows that after $7 \mathrm{~h}$ of $\mathrm{H}_{2} \mathrm{O}_{2}$ treatment there was an approximately 4-fold increase of the total cellular Asc concentration in the EV2 strain, reaching about $1.2 \mathrm{mM}$. The VTC2-amiRNA lines (VTC2-A27 and $V T C 2-B 75$ ) had initially about $10 \%$ Asc relative to the EV2 strain (approximately 40 
$\mu \mathrm{M})$. Upon $\mathrm{H}_{2} \mathrm{O}_{2}$ treatment, there was a considerable increase of their Asc contents, but it did not reach the level of the untreated EV2 strain. $23 \mathrm{~h}$ after addition of $\mathrm{H}_{2} \mathrm{O}_{2}$, the Asc content almost returned to the initial level in all strains.

After $7 \mathrm{~h}$ of treatment at normal growth light intensity in the presence or absence of $\mathrm{H}_{2} \mathrm{O}_{2}$, the samples were either transferred to high light (530 $\mu$ mole photons $\left.\mathrm{m}^{-2} \mathrm{~s}^{-1}\right)$ or kept at the growth light intensity $\left(80 \mu\right.$ mole photon $\left.\mathrm{m}^{-2} \mathrm{~s}^{-1}\right)$ for another $16 \mathrm{~h}$. In response to the high-light treatment alone, there was an approximately two-fold increase in the Asc content in the EV2 strain and a four-fold increase in the VTC2-amiRNA lines. When the $1.5 \mathrm{mM} \mathrm{H}_{2} \mathrm{O}_{2}$ treatment preceded the high-light treatment, the final Asc level in the EV2 samples was about $40 \%$ higher than following the high-light treatment alone. By contrast, in the VTC2-amiRNA lines, the $\mathrm{H}_{2} \mathrm{O}_{2}$ pre-treatment did not further enhance Asc production relative to the high-light treatment alone.

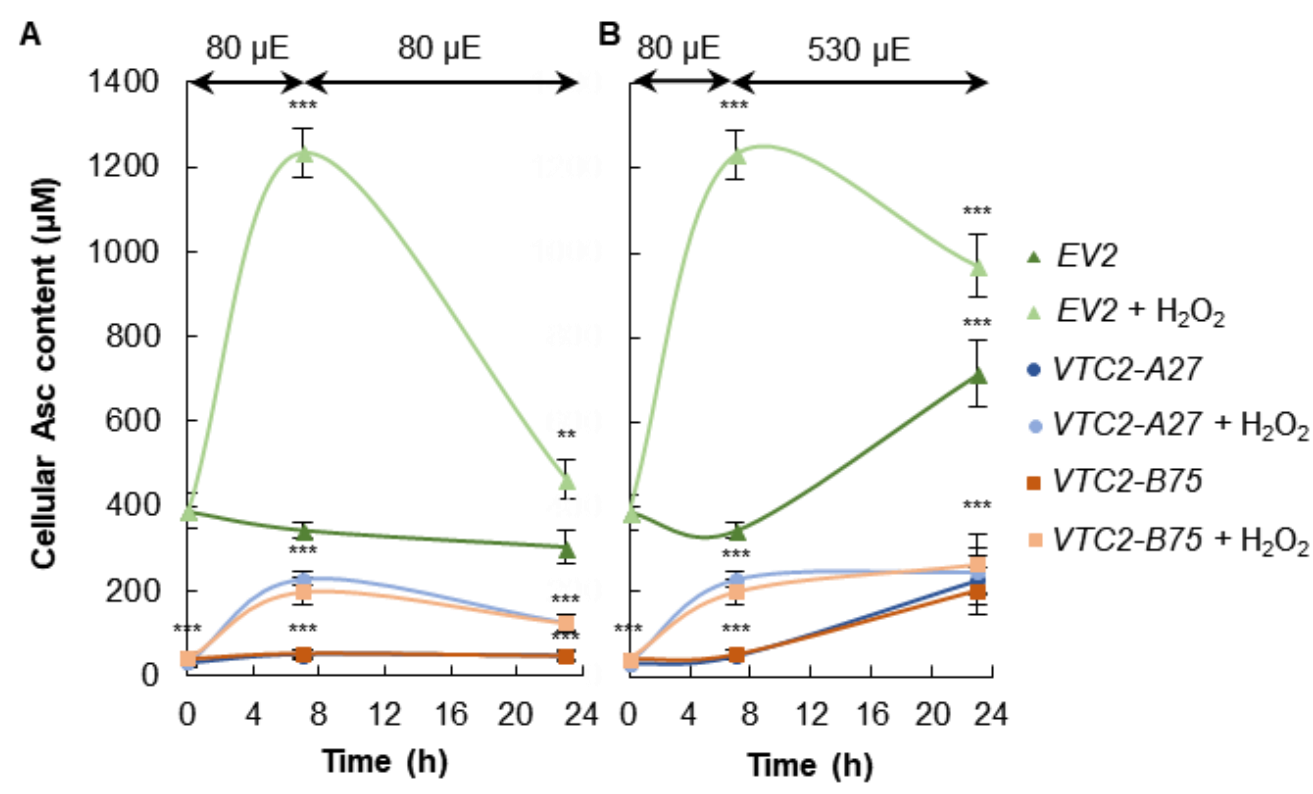

Figure 9. The effects of $1.5 \mathrm{mM} \mathrm{H}_{2} \mathrm{O}_{2}$ and high light on the cellular Asc contents in the $E V 2, V T C 2-A 27$ and $V T C 2-B 75$ transformants of $C$. reinhardtii. (A) Asc contents of the cultures grown under normal light $\left(80 \mu\right.$ mole photons $\left.\mathrm{m}^{-2} \mathrm{~s}^{-1}\right)$ and treated with or without $1.5 \mathrm{mM} \mathrm{H}_{2} \mathrm{O}_{2}$. (B) Asc contents of the cultures transferred to high light $\left(530 \mu\right.$ mole photons $\left.\mathrm{m}^{-2} \mathrm{~s}^{-1}\right)$ after treating them with or without $1.5 \mathrm{mM} \mathrm{H}_{2} \mathrm{O}_{2}$. Statistical significance levels are presented relative to the untreated $E V 2$ strain as: ${ }^{* *} \mathrm{p}<0.01$; $^{* * *} \mathrm{p}<0.001 . \mu \mathrm{E}$ stands for $\mu$ mole photons $\mathrm{m}^{-2} \mathrm{~s}^{-1}$. 
To confirm that the increase in Asc content is related to changes in the VTC2 expression, its transcript abundance was assessed by real-time qPCR. Figure shows that under normal conditions, the transcript level of the VTC2 gene was about $50 \%$ lower in the VTC2-amiRNA lines than in the EV2 control strain. Upon $\mathrm{H}_{2} \mathrm{O}_{2}$ treatment, there was a three-fold increase in the EV2 strain $7 \mathrm{~h}$ after its addition. Surprisingly, the increase was much stronger in the VTC2-amiRNA lines: about eight-fold more VTC2 transcript was detected in the VTC2-amiRNA lines than in the control EV2 samples. However, $23 \mathrm{~h}$ after the addition of $1.5 \mathrm{mM} \mathrm{H}_{2} \mathrm{O}_{2}$, the transcript level of the VTC2 gene decreased strongly in all strains (Figure 10), which is in agreement with the return of the Asc content to the initial level (Figure 9). When the cultures were transferred to high light, the VTC2 transcript level decreased further (Figure 10), even though the Asc contents remained high relative to the cultures kept at normal light (Figure 9).

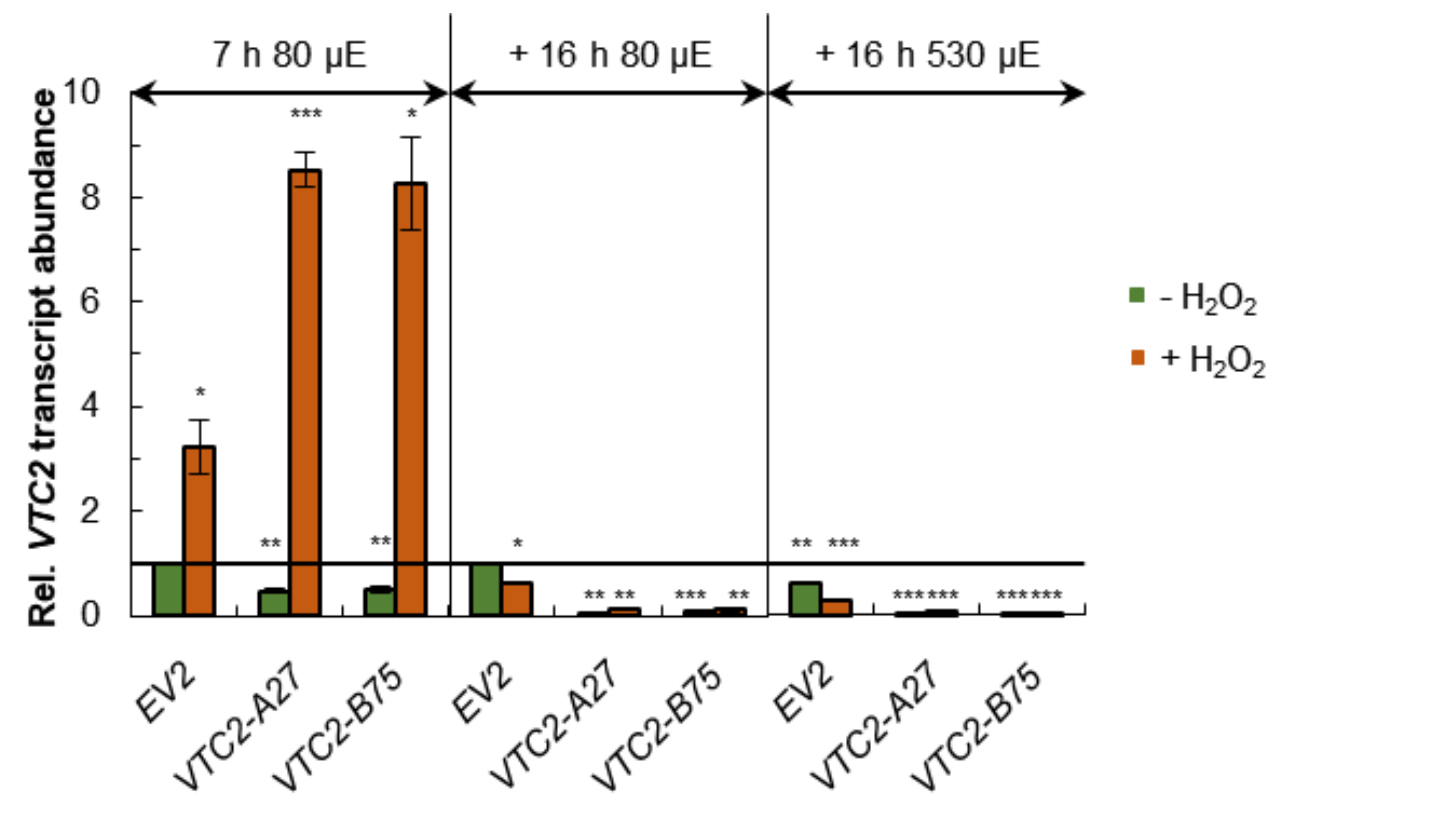

Figure 10. The effects of $1.5 \mathrm{mM} \mathrm{H}_{2} \mathrm{O}_{2}$ and high light on the $V T C 2$ transcript abundances in the $E V 2, V T C 2-A 27$ and $V T C 2-B 75$ transformants of C. reinhardtii. Transcript levels of $V T C 2$ as determined by real-time qPCR upon treatment with $1.5 \mathrm{mM} \mathrm{H}_{2} \mathrm{O}_{2}$, high-light treatment or combination of both treatments. Statistical significance levels are presented relative to the untreated $E V 2$ strain as: $* \mathrm{p}<0.05 ; * * \mathrm{p}<0.01 ; * * * \mathrm{p}<0.001 . \mu \mathrm{E}$ stands for $\mu$ mole photons $\mathrm{m}^{-2} \mathrm{~s}^{-1}$.

Since the increase in VTC2 transcript levels was unexpected in the $\mathrm{H}_{2} \mathrm{O}_{2}$-treated VTC2-amiRNA lines, we also performed a northern blot analysis of 
transcript accumulation. Figure 11 confirmed that the full-length VTC2 mRNA level increased upon $\mathrm{H}_{2} \mathrm{O}_{2}$ treatment, not only in EV2 but also prominently in the VTC2-A27 transformant.

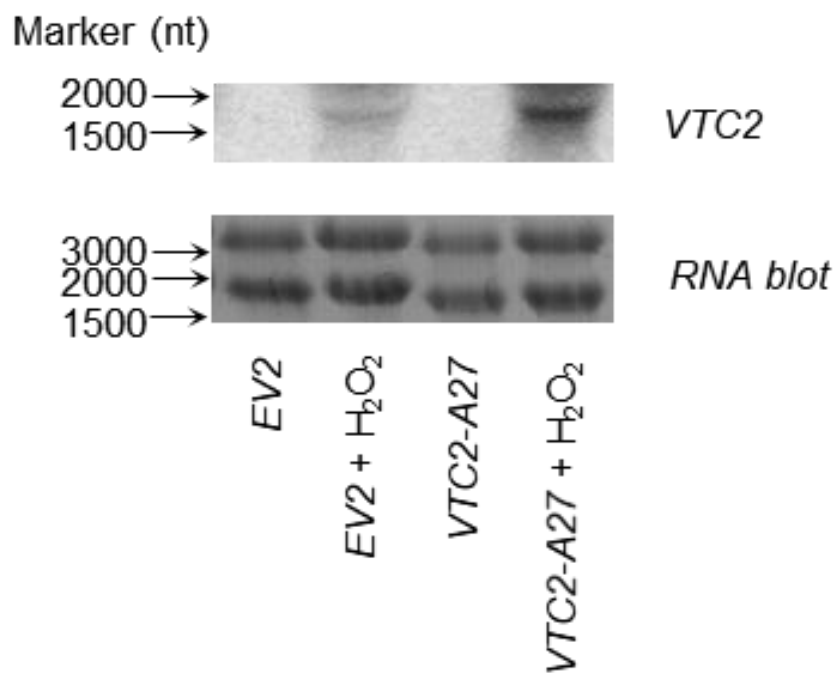

Figure 11. The effects of $1.5 \mathrm{mM} \mathrm{H}_{2} \mathrm{O}_{2}$ and high light on the $V T C 2$ transcript abundances in the $E V 2, V T C 2-A 27$ and $V T C 2-B 75$ transformants of C. reinhardtii. Transcript levels of VTC2 upon treatment with $1.5 \mathrm{mM} \mathrm{H}_{2} \mathrm{O}_{2}$ as determined by northern blot analysis. Samples of $20 \mu \mathrm{g}$ total RNA were loaded. As a control for RNA loading, ethidium bromide stained agarose gel is shown, and sizes of marker bands are indicated. The expected size of the VTC2 transcript is $1813 \mathrm{nt}$.

The impact of $\mathrm{H}_{2} \mathrm{O}_{2}$ and high-light stress on expression of the algal orthologs of the Smirnoff-Wheeler pathway genes (identified by homology searches) was assessed as well. The transcript levels of SNE1 (Cre01.g019250, an orthologue of Arabidopsis GME1, encoding GDP-D-mannose-3',5'-epimerase), INMI (Cre02.g109600, an orthologue of Arabidopsis VTC4) and L-GalDH (L-galactose dehydrogenase, Cre14.g630400) displayed an approximately 50\% decrease in the VTC2-amiRNA lines relative to the EV2 strain under normal conditions (Figure 12). Upon $\mathrm{H}_{2} \mathrm{O}_{2}$ treatment, the transcript abundances of these genes changed only moderately, whereas high-light treatment induced their expression (Figure 12). These results suggest that the regulation of the proposed Smirnoff-Wheeler pathway genes may be different in response to $\mathrm{H}_{2} \mathrm{O}_{2}$ and high-light stress. 

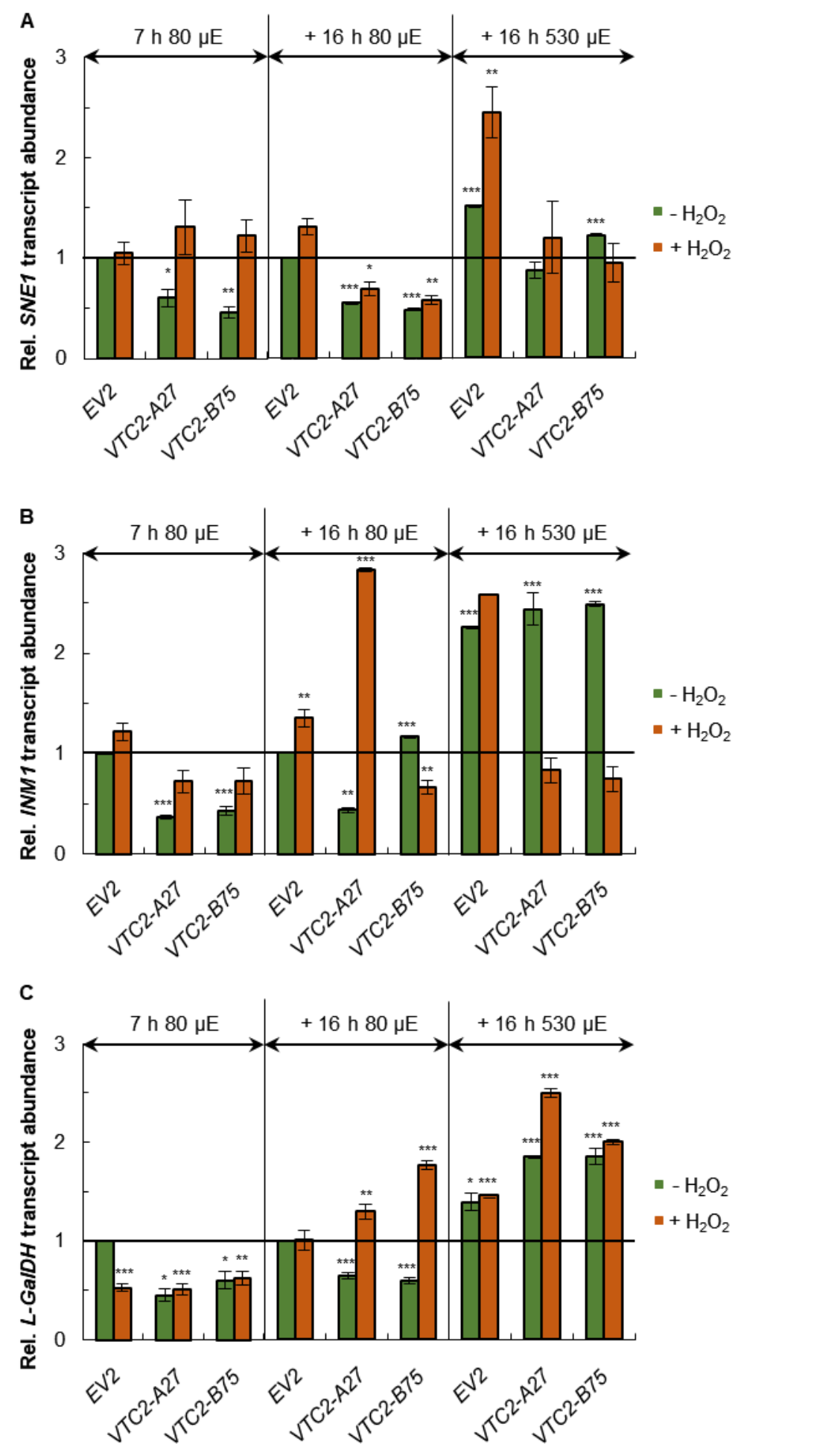

Figure 12. Transcript levels of (A) SNE1, (B) INM1, and (C) L-GalDH upon treatment with $1.5 \mathrm{mM} \mathrm{H}_{2} \mathrm{O}_{2}$, high-light or the combination of both treatments in the $E V 2, V T C 2-A 27$ and $V T C 2-B 75$ strains of $C$. reinhardtii. The experimental conditions are identical as in Figure 9. Mean values $( \pm$ SEM) are each based on 4 biological replicates. Statistical significance levels are presented relative to the untreated $E V 2$ strain as: $* \mathrm{p}<0.05 ; * * \mathrm{p}<0.01$; $* * * \mathrm{p}<0.001 . \mu \mathrm{E}$ stands for $\mu$ mole photons $\mathrm{m}^{-2} \mathrm{~s}^{-1}$. 


\subsection{3) The physiological effects of Asc deficiency in C. reinhardtii}

We also investigated whether the decreased Asc content caused changes in the growth characteristics and pigment composition, using the same experimental setup as described in the previous section. Figure 13 shows that cell density increased at a slightly lower rate $(-20 \%)$ in the VTC2-amiRNA lines relative to the EV2 control. The $\mathrm{H}_{2} \mathrm{O}_{2}$ treatment slowed down cell proliferation particularly in the VTC2-amiRNA lines (by about 30\%) and the high-light stress had similar effects in this respect. The $\mathrm{Chl}(\mathrm{a}+\mathrm{b})$ content per cell in the VTC2-amiRNA transformants was only $45 \%$ of that of the EV2 strain (Figure 14). Similarly, the Chl(a+b) content of the cells decreased upon $\mathrm{H}_{2} \mathrm{O}_{2}$ treatment by about $20 \%$. High-light treatment caused about $25 \%$ decrease, and this effect was slightly enhanced in case a preceding $\mathrm{H}_{2} \mathrm{O}_{2}$ treatment was applied. The $\mathrm{Chl}(\mathrm{a} / \mathrm{b})$ ratio (Figure 15) was also altered in the VTC2-amiRNA transformants, suggesting that their photosynthetic apparatus had a smaller light-harvesting antenna. This ratio did not change upon $\mathrm{H}_{2} \mathrm{O}_{2}$ treatment but decreased slightly upon high-light stress.

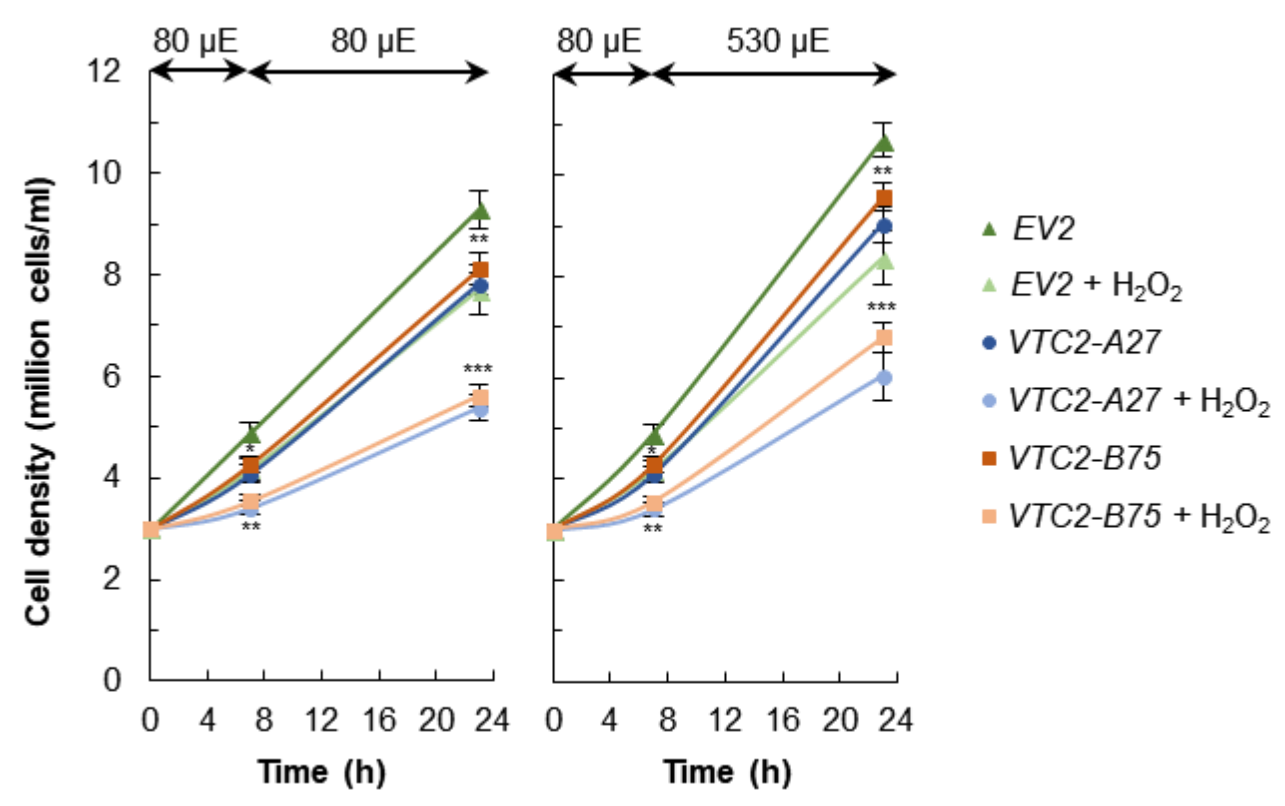

Figure 13. The effects of $1.5 \mathrm{mM} \mathrm{H}_{2} \mathrm{O}_{2}$ and high light (530 $\mu$ mole photons $\mathrm{m}^{-2} \mathrm{~s}^{-1}$ ) on growth in the $E V 2, V T C 2-A 27$ and $V T C 2-B 75$ amiRNA lines of $C$. reinhardtii. The experimental conditions are identical as in Figure 9. Mean values $( \pm$ SEM $)$ are each based on 7 biological replicates. Statistical significance levels are presented relative to the untreated $E V 2$ strain as: $* \mathrm{p}<0.05 ; * * \mathrm{p}<0.01 ; * * * \mathrm{p}<0.001$. $\mu \mathrm{E}$ stands for $\mu$ mole photons $\mathrm{m}^{-2} \mathrm{~s}^{-1}$. 

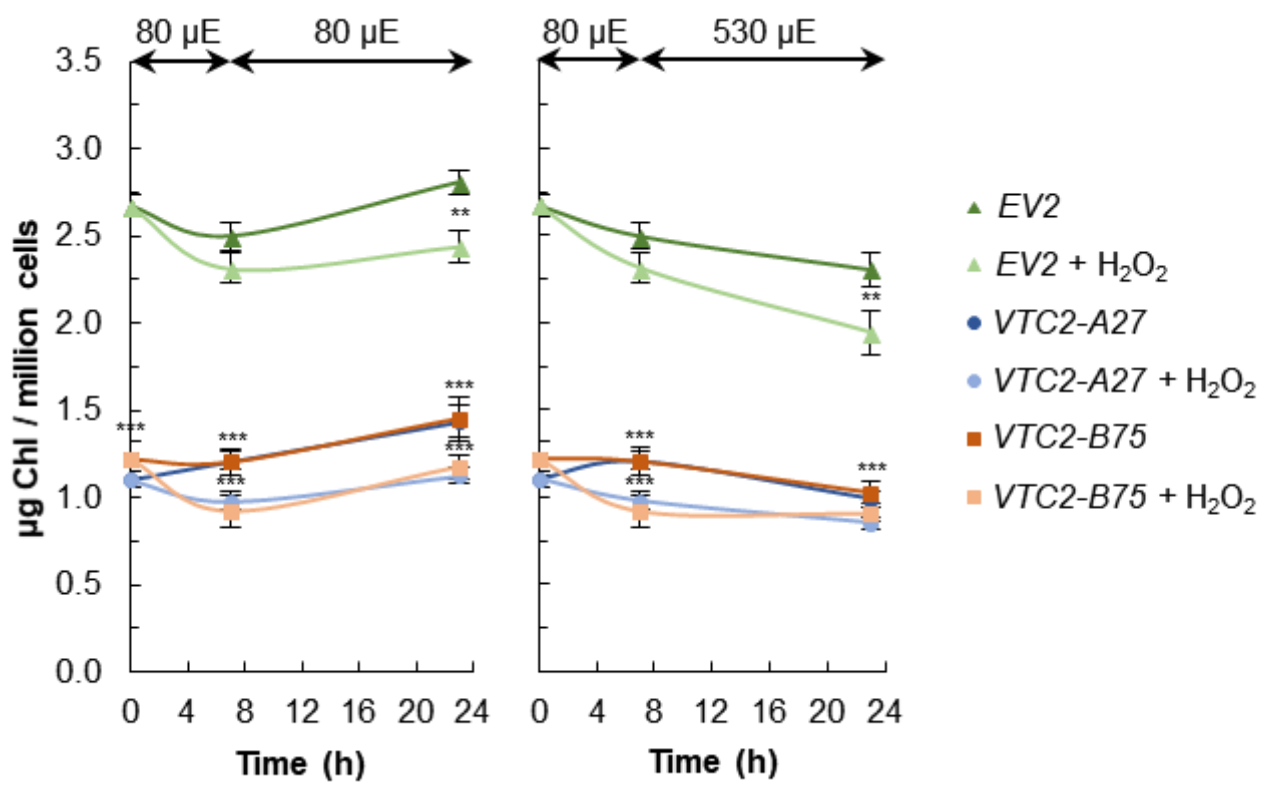

Figure 14. The effects of $1.5 \mathrm{mM} \mathrm{H}_{2} \mathrm{O}_{2}$ and high light $(530 \mu$ mole photons $\left.\mathrm{m}^{-2} \mathrm{~s}^{-1}\right)$ on $\operatorname{chl}(\mathrm{a}+\mathrm{b})$ content in the $E V 2, V T C 2-A 27$ and $V T C 2-B 75$ amiRNA lines of $C$. reinhardtii. The experimental conditions are identical as in Figure 9. Mean values $( \pm$ SEM) are each based on 7 biological replicates. Statistical significance levels are presented relative to the untreated $E V 2$ strain as: $* \mathrm{p}<0.05 ; * * \mathrm{p}<0.01 ; * * *$ $\mathrm{p}<0.001 . \mu \mathrm{E}$ stands for $\mu$ mole photons $\mathrm{m}^{-2} \mathrm{~s}^{-1}$.
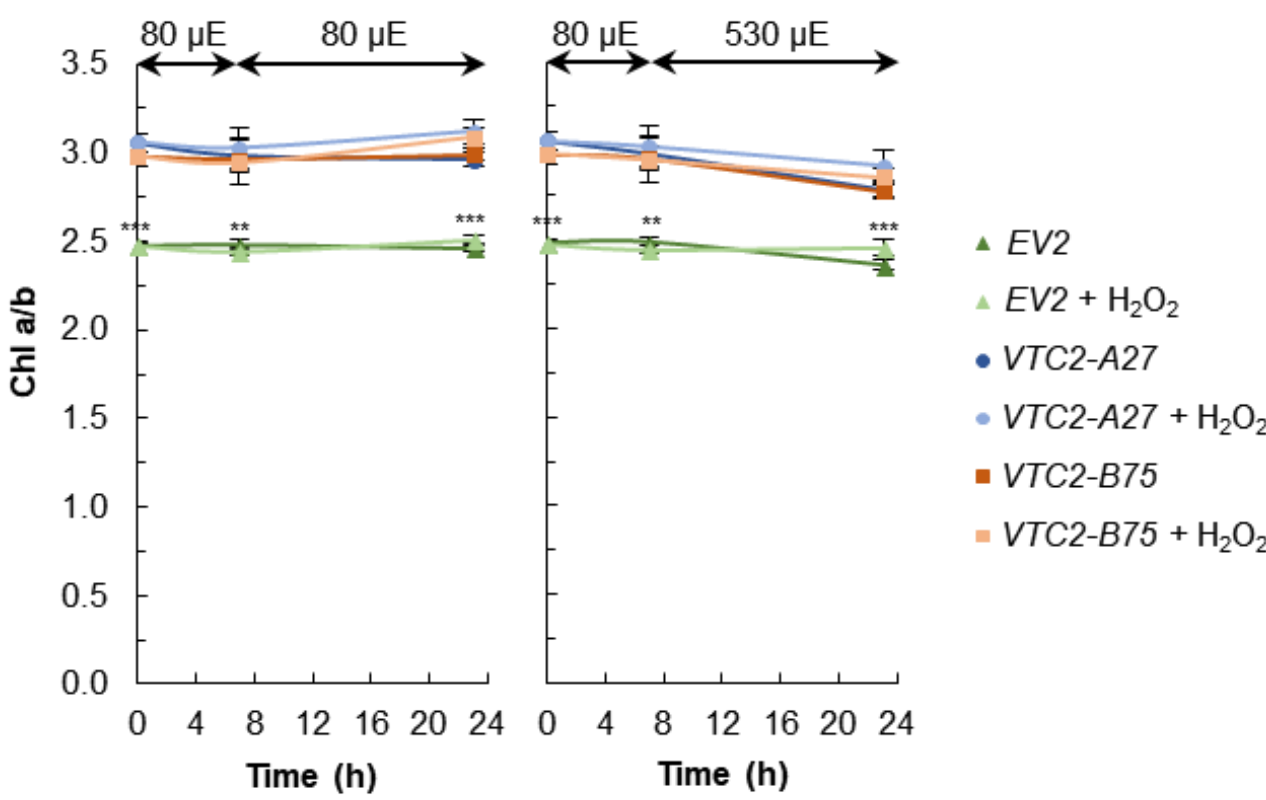

Figure 15. The effects of $1.5 \mathrm{mM} \mathrm{H}_{2} \mathrm{O}_{2}$ and high light (530 $\mu$ mole photons $\left.\mathrm{m}^{-2} \mathrm{~s}^{-1}\right)$ on $\operatorname{chl}(\mathrm{a} / \mathrm{b})$ ratios in the $E V 2, V T C 2-A 27$ and $V T C 2-B 75$ amiRNA lines of C. reinhardtii. The experimental conditions are identical as in Figure 9. Mean values $( \pm$ SEM) are each based on 7 biological replicates. Statistical significance levels are presented relative to the untreated $E V 2$ strain as: ${ }^{*} \mathrm{p}<0.05 ; * * \mathrm{p}<0.01 ; * * * \mathrm{p}<0.001$. $\mu \mathrm{E}$ stands for $\mu$ mole photons $\mathrm{m}^{-2} \mathrm{~s}^{-1}$. 
In the chloroplast stroma, $\mathrm{H}_{2} \mathrm{O}_{2}$ is reduced to $\mathrm{H}_{2} \mathrm{O}$ by $\mathrm{APX}$, resulting in oxidation of Asc to MDAR, which can be either reduced to Asc by the action of MDAR, or it spontaneously disproportionate to DHA. DHA can be reduced back to Asc by DHAR. In the VTC2-amiRNA lines, the transcript abundances of APXI and DHAR1, the main chloroplastic forms of these enzymes, were about $40 \%$ lower than in the EV2 control (Figure 16). Upon the $\mathrm{H}_{2} \mathrm{O}_{2}$ treatment the expression levels of these genes increased, and they also responded to high-light treatment, with significant differences between the VTC2-amiRNA lines and the EV2 control strain, suggesting that complex adaptation processes are involved in the response to Ascdeficiency.
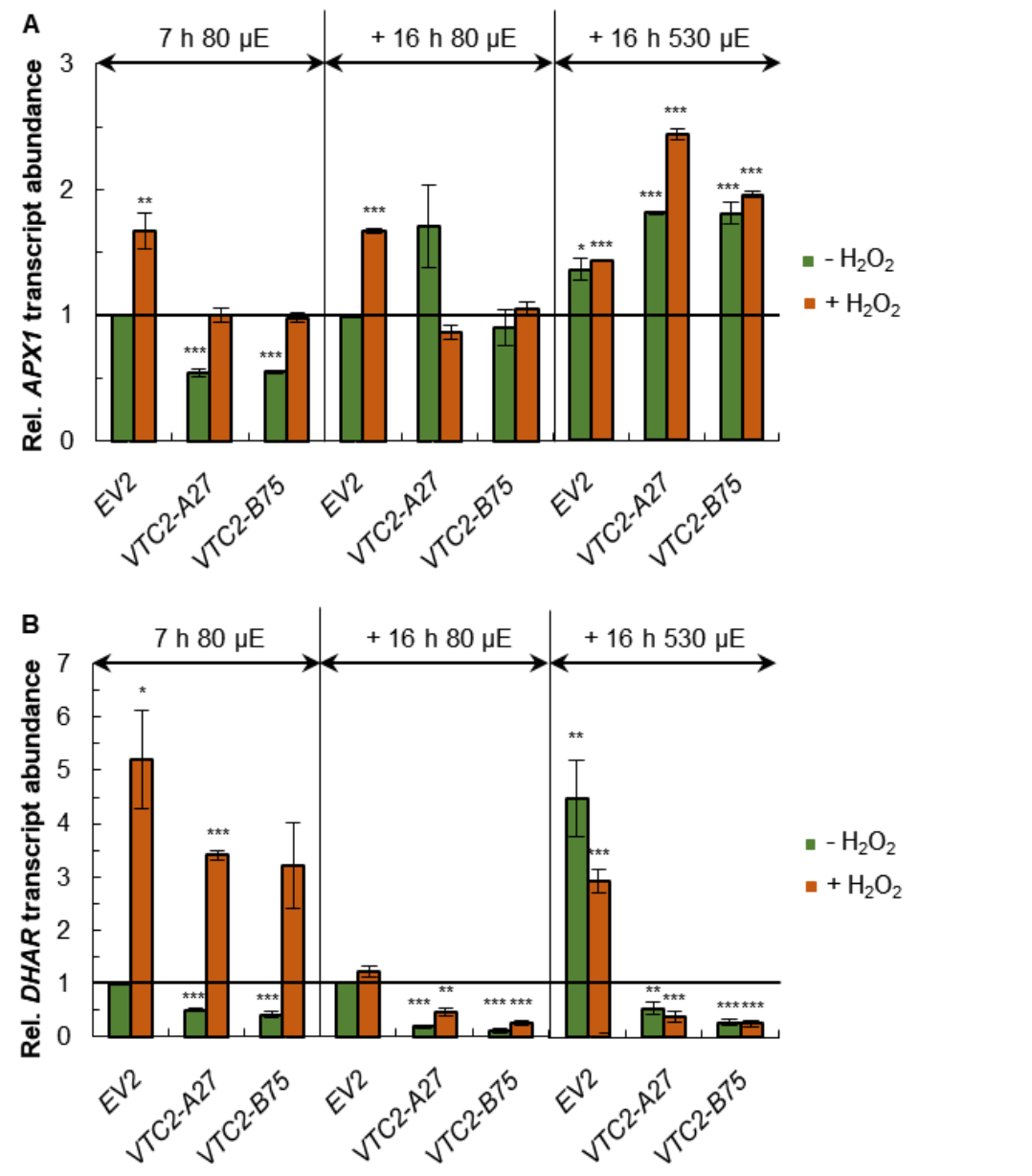

Figure 16. The effects of $1.5 \mathrm{mM} \mathrm{H}_{2} \mathrm{O}_{2}$ and high light (530 $\mu$ mole photons $\mathrm{m}^{-2} \mathrm{~s}^{-1}$ ) on gene expression in the $E V 2, V T C 2-A 27$ and $V T C 2-B 75$ transformants of $\boldsymbol{C}$. reinhardtii. Transcript levels of (A) APXI and (B) DHAR were measured upon treatment with $1.5 \mathrm{mM} \mathrm{H} \mathrm{H}_{2} \mathrm{O}_{2}$, high-light treatments or combination of both treatments. The experimental conditions are identical as in Figure 9. Mean values $( \pm$ SEM) are each based on 4 biological replicates. Statistical significance levels are presented relative to the untreated EV2 strain as: $* \mathrm{p}<0.05 ; * * \mathrm{p}<0.01 ; * * * \mathrm{p}<0.001 . \mu \mathrm{E}$ stands for umole photons $\mathrm{m}^{-2} \mathrm{~s}^{-1}$. 
Metabolite profiling was next performed focusing on the $\mathrm{H}_{2} \mathrm{O}_{2}$ treatment. Figure 17 shows that, upon $\mathrm{H}_{2} \mathrm{O}_{2}$ stress, alanine and proline accumulated, whereas the amount of cystine strongly decreased in the VTC2-amiRNA lines. The amounts of aspartic acid, lysine and ornithine were also lower in the VTC2-amiRNA lines under control conditions, but these differences were much smaller following $\mathrm{H}_{2} \mathrm{O}_{2}$ stress. Changes in the tricarboxylic acid cycle intermediates were also apparent. Following $\mathrm{H}_{2} \mathrm{O}_{2}$ treatment, the amount of pyruvic acid and citric acid decreased, in particular in the VTC2-amiRNA lines, but the amounts of malic acid and succinic acid increased in all the lines. Furthermore, the amount of mannose and glycerol-3-phosphate decreased in the VTC2-amiRNA lines, particularly following $\mathrm{H}_{2} \mathrm{O}_{2}$ treatment in the case of the latter.

In general, the metabolite profiling data indicate that the VTC2-amiRNA lines are under chronic stress, since the increased proline and decreased glycerol-3-phosphate contents are changes that have been documented to commonly occur under a range of abiotic stresses (Obata and Fernie, 2012), and these effects were enhanced by the $\mathrm{H}_{2} \mathrm{O}_{2}$ treatment.

\subsection{4) The effects of Asc-deficiency on photosynthetic electron transport}

In order to assess whether Asc-deficiency limits photosynthetic electron transport in $C$. reinhardtii, we measured the ETR(II) and the ETR(I) parameters in our EV2 and VTC2-A27 strains. Given that the VTC2-amiRNA lines had a reduced Chl content per cell (Figure 14), the electron transport rates were measured on an equal Chl content basis $(30 \mu \mathrm{g} \mathrm{Chl}(\mathrm{a}+\mathrm{b}))$. Figure $18 \mathrm{~A}$ shows that the maximum ETR(II) was about 50\% lower in the VTC2-A27 transformant than in the EV2 strain. The effect of Asc deficiency on ETR(I) was even more pronounced: above 200 $\mu$ mole photon $\mathrm{m}^{-2} \mathrm{~s}^{-1}$, the $\operatorname{ETR}(\mathrm{I})$ parameter decreased very strongly in the VTC2-amiRNA line (Figure 18 B).

Asc supplementation ( $2 \mathrm{mM} \mathrm{Na-Asc,} 2 \mathrm{~h}$ incubation at $80 \mu$ mole photon $\mathrm{m}^{-2}$ $\mathrm{s}^{-1}$ ) increased the cellular Asc content of the VTC2-A27 strain to the level of the EV2 strain (Figure 18 B), and the ETR(I) and ETR(II) parameters also increased significantly (Figure $18 \mathrm{~A}$ and $\mathrm{B})$. These results show that, in contrast to higher plants, Asc-deficiency severely affects photosynthetic electron transport in the cw15-325 strain of $C$. reinhardtii, but that phenotype can be largely rescued by externally added Asc. 


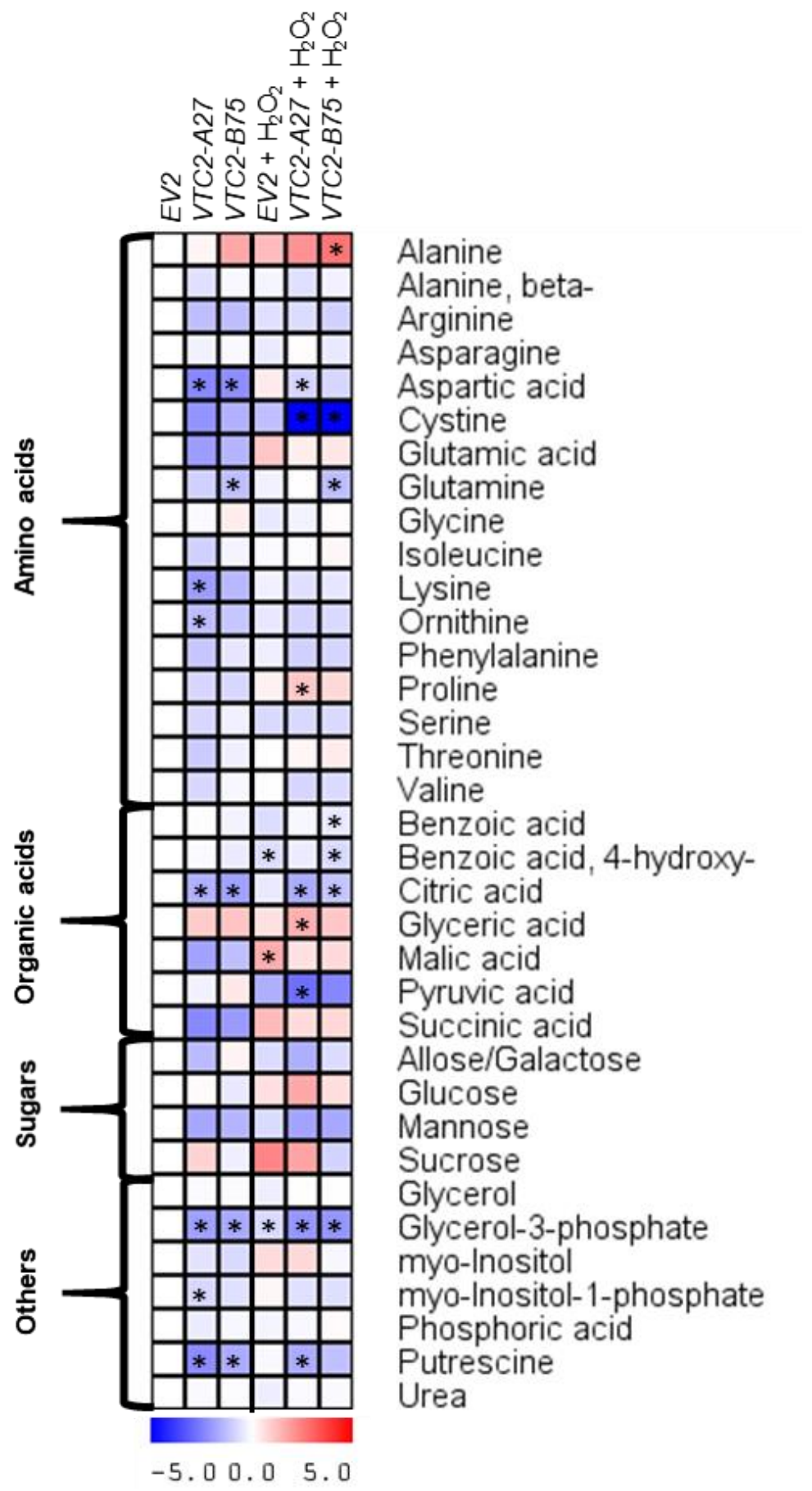

Figure 17. Metabolite profiling of $C$. reinhardtii $E V 2, V T C 2-A 27$ and VTC2-B75 strains treated with or without $1.5 \mathrm{mM} \mathrm{H}_{2} \mathrm{O}_{2}$ under normal light conditions. The color scale represents increase (in red) or decrease (in blue) for each metabolite detected compared to the EV2 strain under control conditions. Values are presented as mean $(n=4-5)$ and $\log 2$ transformed. Statistical significance levels are presented relative to the untreated $E V 2$ strain as: ${ }^{*} \mathrm{p}<0.05$. 
A

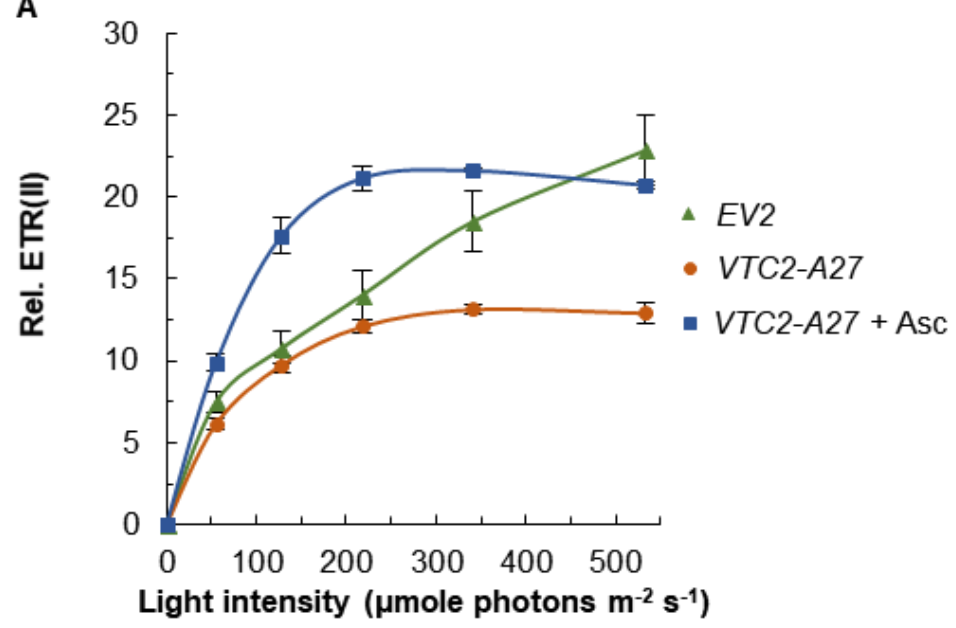

B

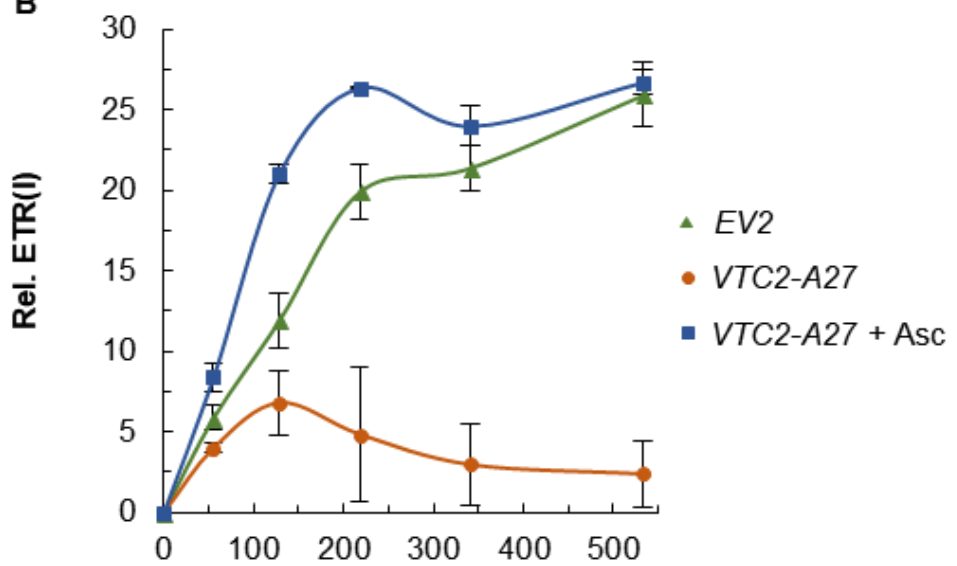

Light intensity ( $\mu$ mole photons $\mathrm{m}^{-2} \mathrm{~s}^{-1}$ )

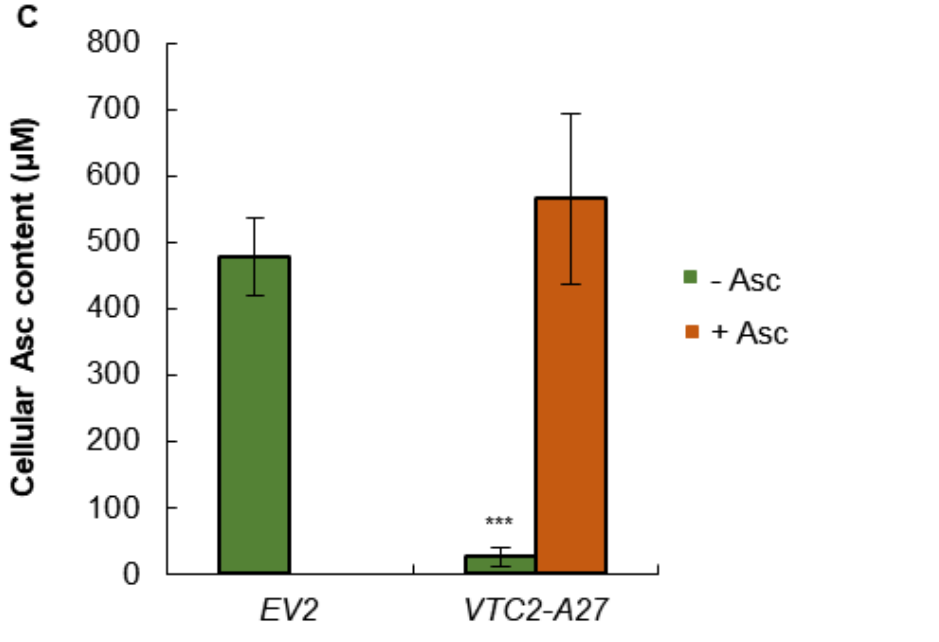

Figure 18. Photosynthetic electron transport rates for (A) PSII (relative ETR(II)) and (B) PSI (relative ETR(I)) of C. reinhardtii EV2 and VTC2-A27 strains with or without the addition of $2 \mathrm{mM}$ Na-Asc and incubation for $2 \mathrm{~h}$ at growth light intensity. C) Cellular Asc contents of EV2 and VTC2-A27 strains 2 $h$ after the addition of $2 \mathbf{~ m M ~ N a - A s c . ~ M e a n ~ v a l u e s ~}( \pm$ SEM) are each based on 4 biological replicates. Statistical significance levels are presented relative to the untreated $E V 2$ strain as: $* * * \mathrm{p}<0.001$. 


\subsection{5) Dependence of the Asc biosynthesis on the photosynthetic electron}

\section{transport chain}

In higher plants, Asc biosynthesis is linked to photosynthetic electron transport (Yabuta et al., 2007). In order to study if this is the case also for Chlamydomonas, we performed treatments with DCMU, an inhibitor of photosynthesis that blocks the plastoquinone-binding site of photosystem II. With these experiments, it would be possible to investigate whether Asc biosynthesis can also be induced by ${ }^{1} \mathrm{O}_{2}$, produced mainly in PSII (Vass, 2012). We treated the cultures with $\mathrm{RB}$, a photosensitizer that triggers ${ }^{1} \mathrm{O}_{2}$ formation. We used $\mathrm{RB}$ in combination with DCMU, in order to exclude possible side effects of RB on photosynthetic electron transport (Kovács et al., 2014) and to avoid the production of $\mathrm{H}_{2} \mathrm{O}_{2}$. The $100 \mu \mathrm{M}$ DCMU treatment completely inhibited the photosynthetic electron transport chain as measured by chl a fluorescence (Figure 19 A) and $\mathrm{O}_{2}$ evolution (Figure $19 \mathrm{~B}$ ). The $\mathrm{H}_{2} \mathrm{O}_{2}$ level did not increase upon the $5 \mu \mathrm{M}$ RB treatment combined with $100 \mu \mathrm{M}$ DCMU in either strain relative to the control (Figure $19 \mathrm{C}$ ), but it was always higher in the VTC2-A27 strain compared to the EV2 strain.

DCMU and RB resulted in a rapid increase of cellular Asc content in the EV2 strain, from about 0.6 to $1.8 \mathrm{mM}$ (combined application) within only $2 \mathrm{~h}$ (Figure 20 A). In the VTC2-A27 transformants, the Asc content was initially about $50 \mu \mathrm{M}$, but also reached the $1.8 \mathrm{mM}$ upon RB treatment, while DCMU treatment alone led only to a moderate increase. Figure $20 \mathrm{~B}$ shows that all these treatments led to significant increase of the VTC2 transcript abundance in both strains.

Taken together, these data show that Asc biosynthesis is not directly dependent on photosynthetic electron transport, because upon inhibition of electron transport with DCMU, increased VTC2 transcript abundance and Asc content were observed.

To investigate whether PSI cyclic electron transport plays a role in the regulation of Asc biosynthesis, we measured the Asc content of the pgrll mutant, in which PSI cyclic electron transport is impaired (Tolleter et al., 2011). There were no significant differences between the pgrll mutant and its corresponding parental strain (CC-124), both under normal conditions and after $\mathrm{H}_{2} \mathrm{O}_{2}$ treatment, demonstrating that Asc biosynthesis is not dependent of PSI cyclic electron transport (Figure 21). 
In order to further investigate the light dependence of Asc biosynthesis, we placed the cultures in the dark. Figure 22 shows that after $7 \mathrm{~h}$ of darkness, the Asc content decreased to about $50 \mu \mathrm{M}$ in the EV2 strain and became undetectable in the VTC2-A27 transformant. When $\mathrm{H}_{2} \mathrm{O}_{2}$ was added, which was shown to trigger Asc biosynthesis in the light, there was an increase in the Asc content of both strains. This data shows that Asc biosynthesis in C. reinhardtii is not strictly light-dependent, since it can be induced by $\mathrm{H}_{2} \mathrm{O}_{2}$ in the dark.

A

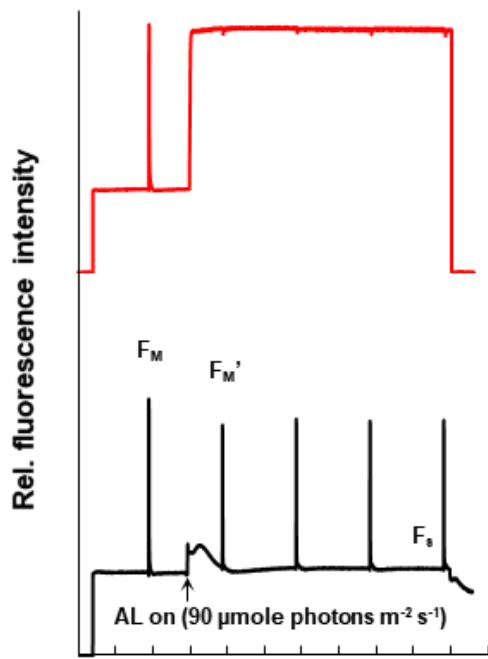

$\begin{array}{lllllllllllll}0 & 1 & 2 & 3 & 4 & 5 & 6 & 7 & 8 & 9 & 10 & 11\end{array}$ Time (min)

B

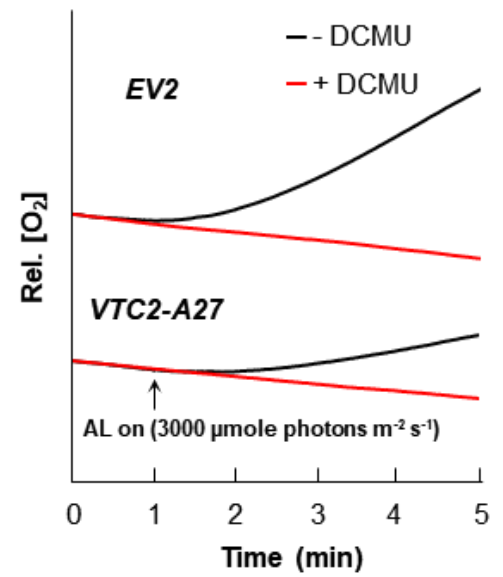

VTC2-A27

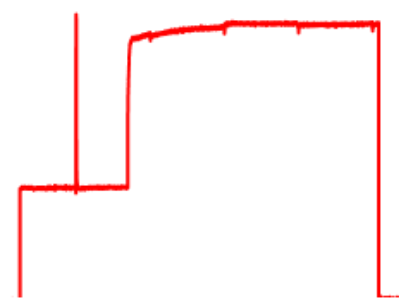

- - DCMU

$-+\mathrm{DCMU}$

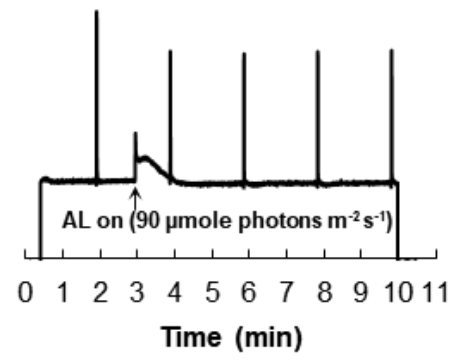

C

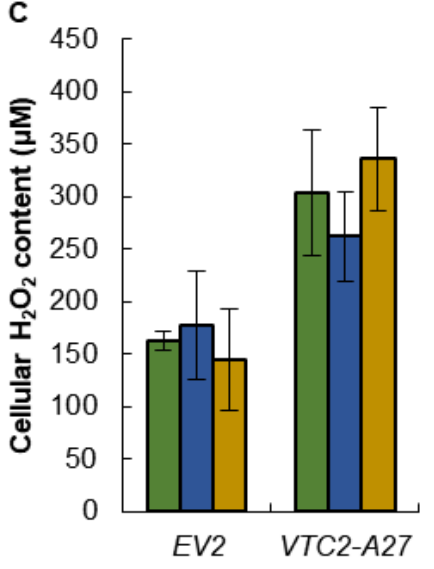

- Control

- + DCMU

+ + DCMU + RB

Figure 19. The effect of $100 \mu \mathrm{M}$ DCMU on photosynthetic electron transport as monitored by $\mathrm{Chl} a$ fluorescence (A) and $\mathrm{O}_{2}$ evolution (B), and the effects of $5 \mu \mathrm{M} \mathrm{RB}$ and $100 \mu \mathrm{M}$ DCMU on the $\mathrm{H}_{2} \mathrm{O}_{2}$ content $(C)$ of $C$. reinhardtii $\boldsymbol{E V} 2$ and $\boldsymbol{V T C 2}-\boldsymbol{A 2 7}$ strains. Mean values $( \pm$ SEM) are each based on 3-5 biological replicates. 

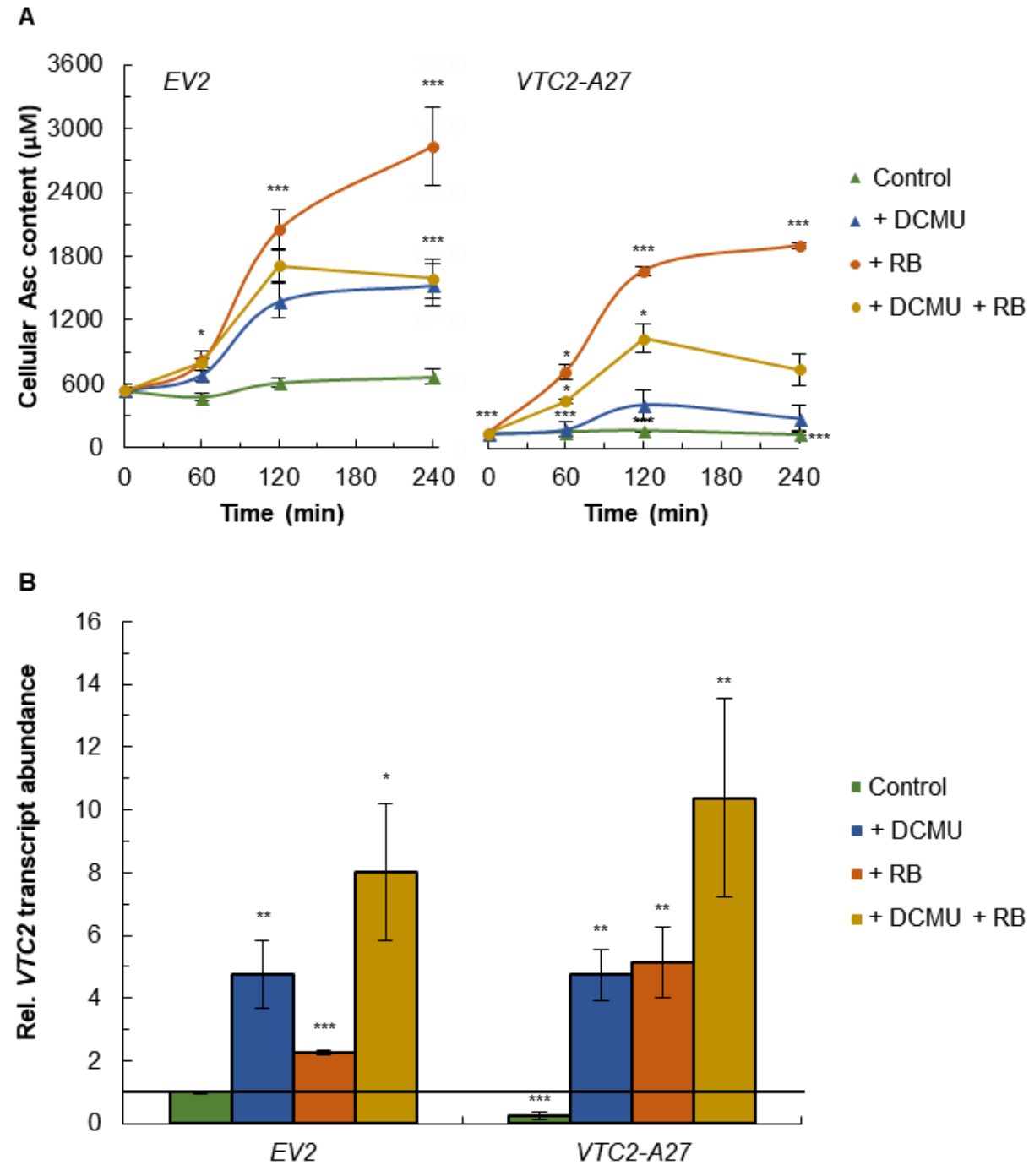

Figure 20. The effect of $5 \mu \mathrm{M} R B$ and $100 \mu \mathrm{M}$ DCMU on the cellular Asc content (A) and VTC2 transcript levels (B) of C. reinhardtii EV2 and VTC2-A27 strains. Mean values $( \pm$ SEM) are each based on 3-5 biological replicates. Statistical significance levels are presented relative to the untreated EV2 strain as: $* \mathrm{p}<0.05$; ** $\mathrm{p}<0.01$; *** $\mathrm{p}<0.001$. 


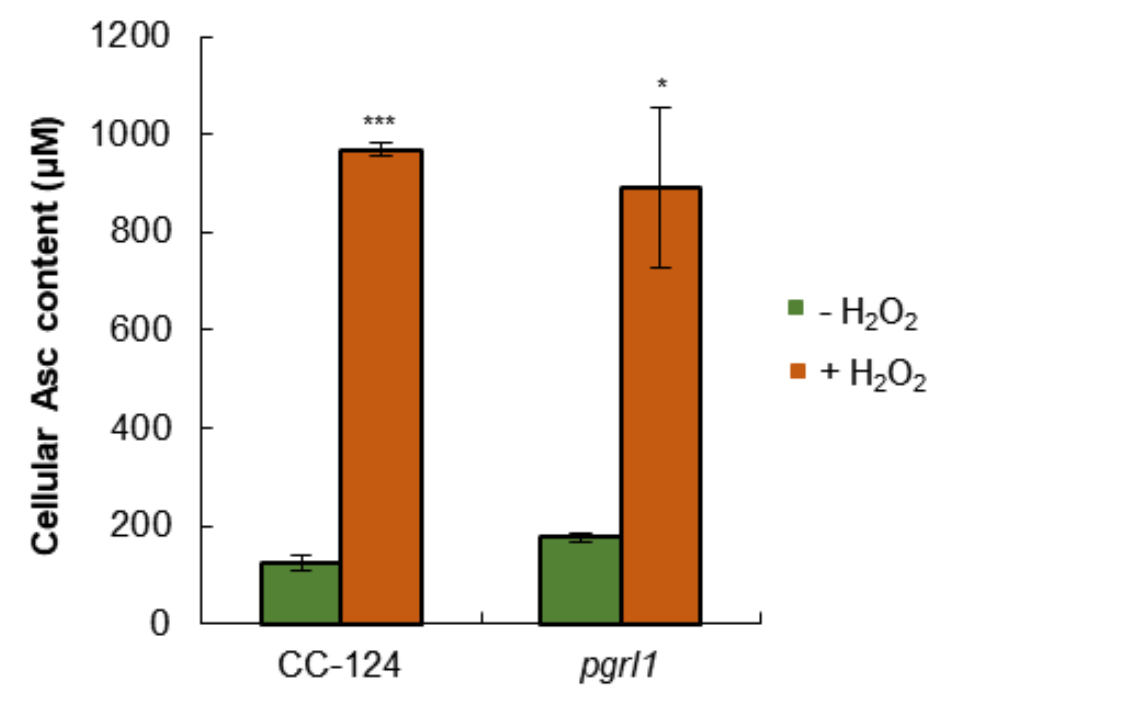

Figure 21. Cellular Asc content of the pgrl1 mutant of $C$. reinhardtii and the corresponding wild-type strain $\mathrm{CC}-124$ grown under normal conditions and

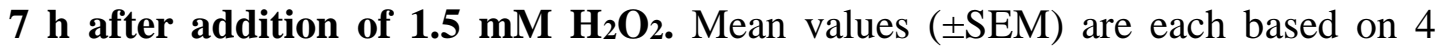
biological replicates. Statistical significance levels are presented relative to the control CC124 strain as: $* \mathrm{p}<0.05 ; * * \mathrm{p}<0.01 ; * * * \mathrm{p}<0.001$.

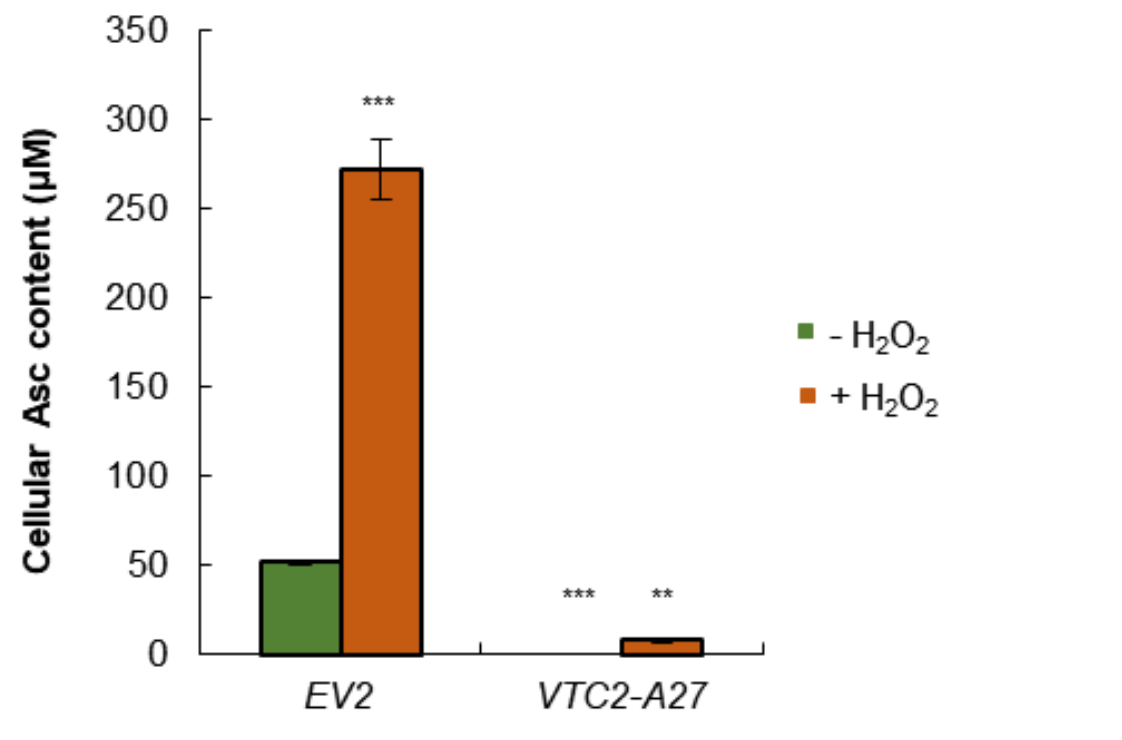

Figure 22. Total Asc content of $C$. reinhardtii EV2 and VTC2-A27 strains

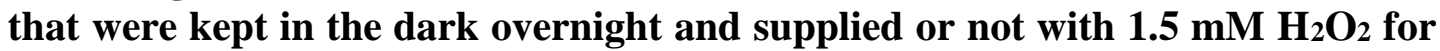
an additional $7 \mathbf{h}$ in the dark. Mean values $( \pm$ SEM) are each based on 3 biological replicates. Statistical significance levels are presented relative to the untreated $E V 2$ strain as: $* * \mathrm{p}<0.01 ; * * * \mathrm{p}<0.001$ 
4.1.6) Asc biosynthesis upon dark-to-light transition and during the circadian cycle

The dark-to-light transition can result in the accumulation of $\mathrm{H}_{2} \mathrm{O}_{2}$ (Shao et al., 2007), which in turn may trigger Asc accumulation. To test whether this was indeed the case, we determined the $\mathrm{H}_{2} \mathrm{O}_{2}$ content of our samples. We found that in the dark-adapted samples, the concentration of $\mathrm{H}_{2} \mathrm{O}_{2}$ was about twice as high in the VTC2-A27 transformant as compared to the EV2 line. Upon illumination, the $\mathrm{H}_{2} \mathrm{O}_{2}$ concentration increased significantly, reaching a maximum at around $30 \mathrm{~min}$ (Figure $\underline{23})$.

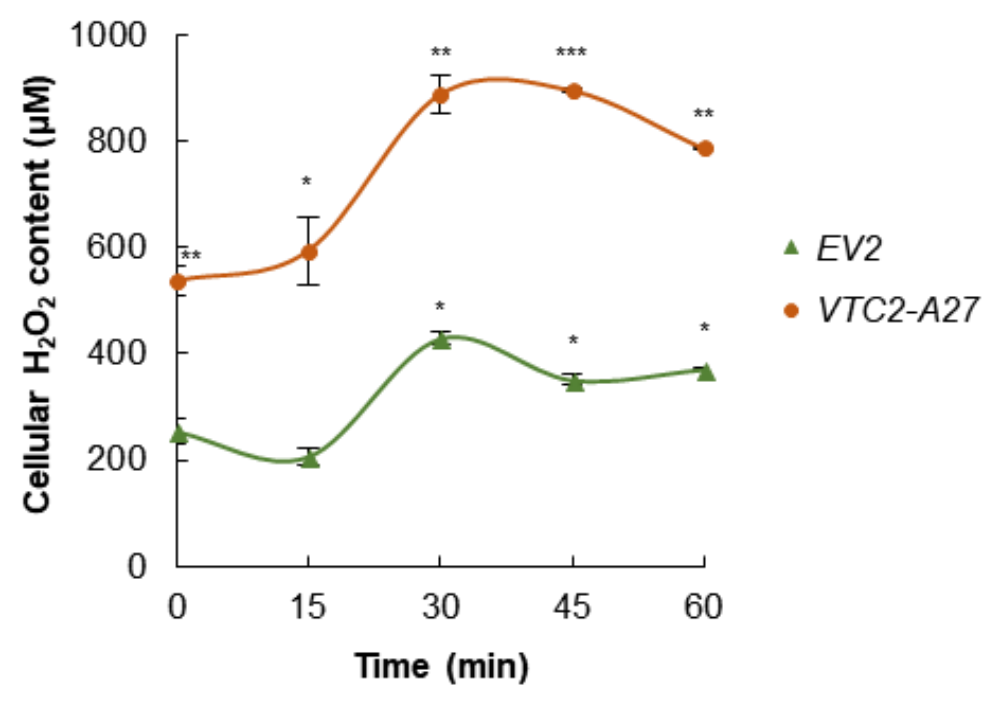

Figure 23. The effects of dark-to-light transition on $\mathrm{H}_{2} \mathrm{O}_{2}$ contents of $C$. reinhardtii $\boldsymbol{E V 2}$ and $\boldsymbol{V T C 2}-\boldsymbol{A} 27$ strains. The cultures were dark-adapted overnight, followed by illumination with growth light $\left(80 \mu\right.$ mole photons $\left.\mathrm{m}^{-2} \mathrm{~s}^{-1}\right)$. Mean values $( \pm$ SEM) are each based on 3 biological replicates. Statistical significance levels are presented relative to the untreated $E V 2$ strain as: $* \mathrm{p}<0.05 ; * * \mathrm{p}<0.01 ; * * * \mathrm{p}<0.001$.

In higher plants, Asc accumulation and VTC2 expression are under circadian control (Gao et al., 2011) and similarly, it has also been described that Asc concentration follows a circadian rhythm in the single-celled flagellate Euglena gracilis (Kiyota et al., 2006). In order to investigate whether Asc biosynthesis is also under circadian control in $C$. reinhardtii, we subjected cultures to four light-dark cycles (10 h light/14 h darkness), followed by continuous illumination for two days. Figure 24 shows that on the fourth day of the light-dark cycles there was a strong increase in Asc content in the light period, particularly in the EV2 transformant, 
whereas after a few hours of darkness it immediately decreased to the initial level. When the cultures were subsequently subjected to continuous illumination (abolishing the diurnal rhythm), the Asc content remained at a low, relatively constant level throughout the whole day. The inset of Figure 24 shows that a typical clock gene, ROC15 (Matsuo et al., 2008) showed the expected pattern of its transcript abundance under continuous light.
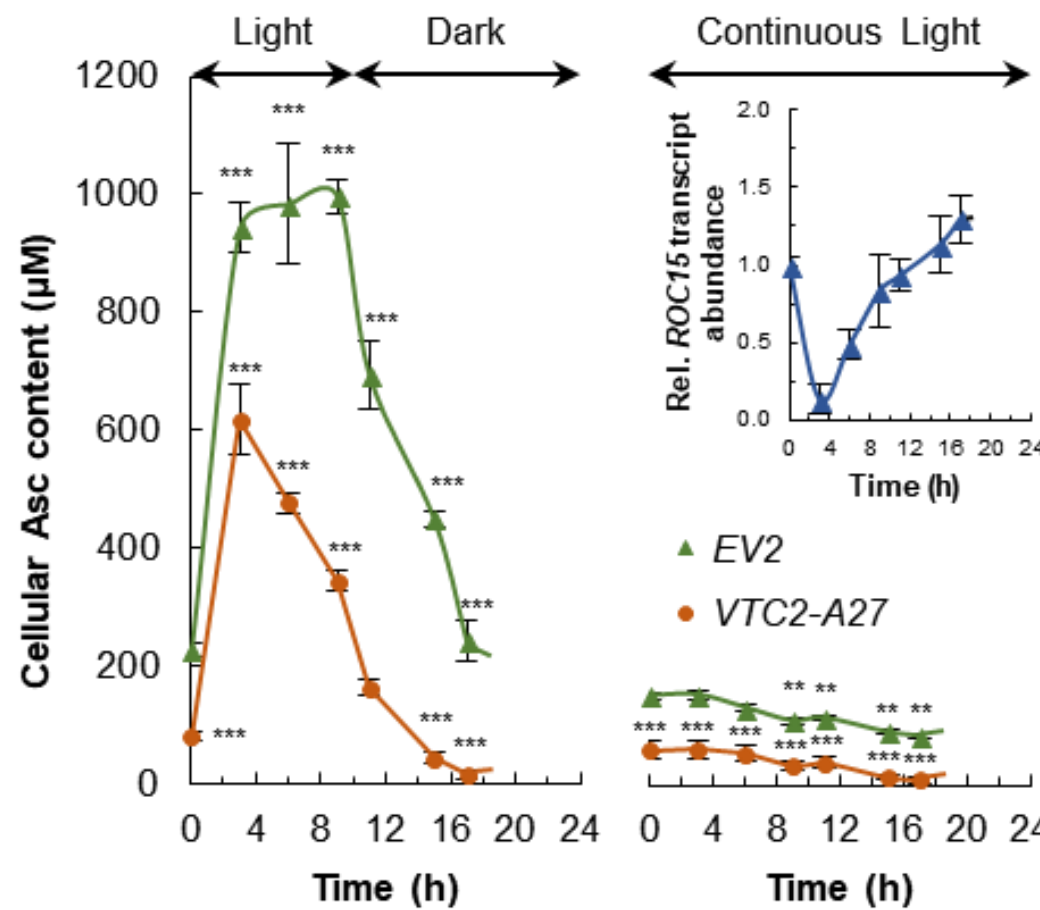

$\triangle E V 2$
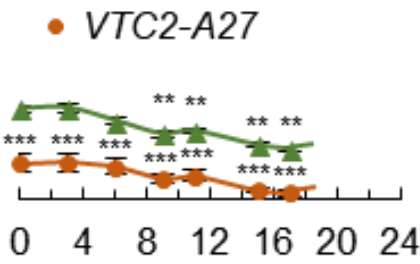

Time (h)

Figure 24. Asc contents of $C$. reinhardtii $E V 2$ and $V T C 2-A 27$ cultures grown under $10 \mathrm{~h}$ light/14 h dark periods for four days (results of Asc measurements at day 4 are shown), followed by continuous illumination for two additional days (results of the second day are shown). As a control, the transcript level of ROC15 in continuous light is shown in the inset. Mean values $( \pm \mathrm{SEM})$ are each based on 4 biological replicates. Statistical significance levels are presented relative to the untreated $E V 2$ strain as: $* \mathrm{p}<0.05 ; * * \mathrm{p}<0.01 ; * * * \mathrm{p}<0.001$.

Finally, we tested whether Asc exerts a feedback regulation on the VTC2 gene, as observed for higher plants (Dowdle et al., 2007). To this end, we supplied the cells with $0.1,0.5$ or $2 \mathrm{mM} \mathrm{Na}$-Asc. These concentrations are physiological and 2 $\mathrm{mM} \mathrm{Na-Asc} \mathrm{is} \mathrm{sufficient} \mathrm{to} \mathrm{recover} \mathrm{photosynthetic} \mathrm{electron} \mathrm{transport} \mathrm{to} \mathrm{a} \mathrm{large}$ extent (Figure 18). Figure $25 \mathrm{~A}$ shows that upon treatment with $2 \mathrm{mM} \mathrm{Na-Asc}$, there was approximately a two-fold increase in the total cellular Asc content in the EV2 transformant, reaching about $1 \mathrm{mM}$. In the VTC2-A27 line, the cellular Asc concentration also increased, from about 100 to $400 \mu \mathrm{M}$. Since the redox status of 
Asc may also determine the cellular responses (Murik et al., 2014), we measured the amount of DHA relative to the total cellular Asc content. Figure $25 \mathrm{~B}$ reveals that the cellular Asc was mostly in its reduced form upon all treatments in both strains (approximately 5 and $12 \%$ was in the oxidized DHA form in the EV2 and the VTC2A27 transformants, respectively).
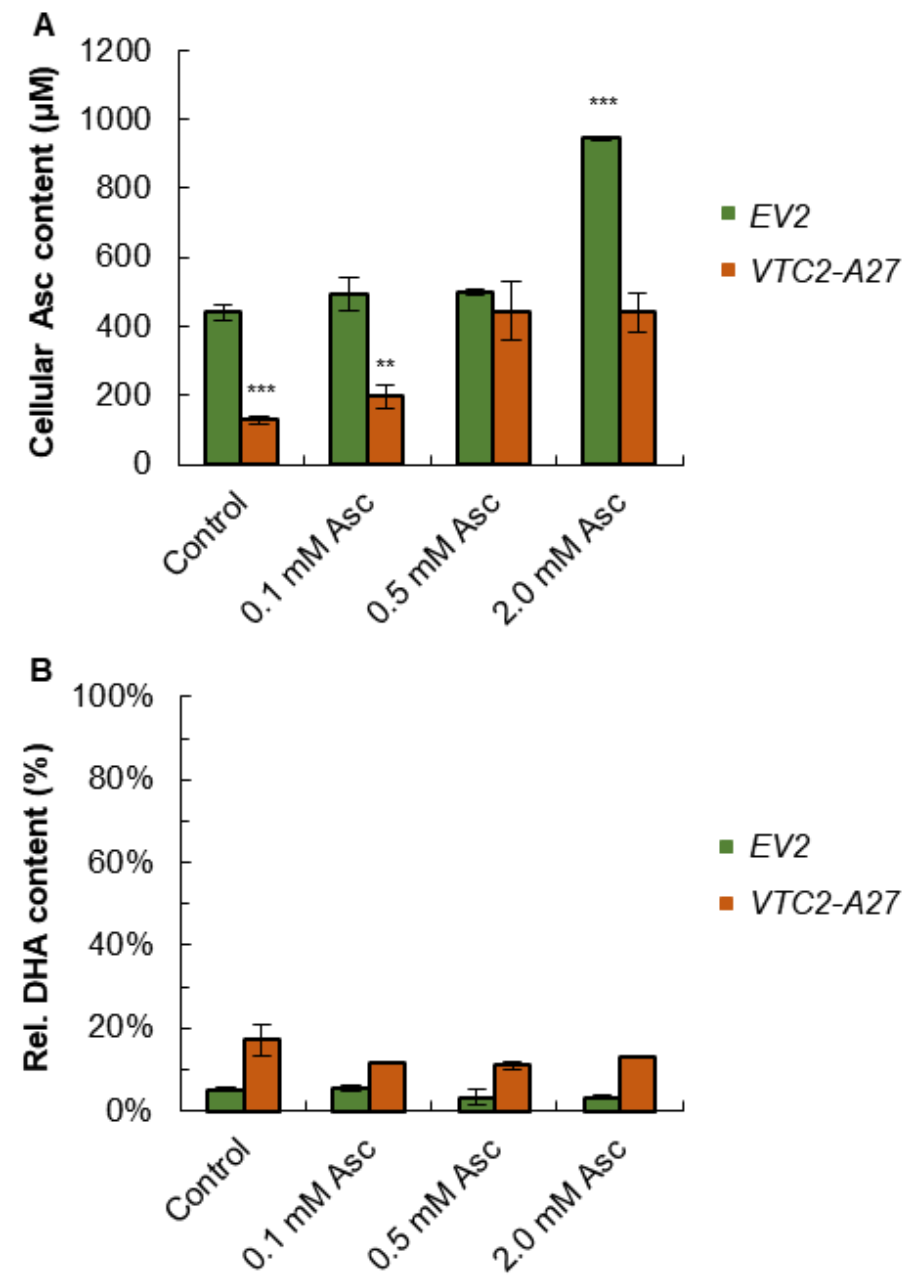

Figure 25. The effects of Asc supplementation on $C$. reinhardtii EV2 and VTC2-A27 strains. (A) Cellular Asc content $4 \mathrm{~h}$ after the addition of $0.1,0.5$ or 2 $\mathrm{mM}$ Na-Asc. (B) Percentage of DHA relative to the total Asc content $4 \mathrm{~h}$ after supplementation with $0.1,0.5$ or $2 \mathrm{mM} \mathrm{Na-Asc}$. Mean values $( \pm \mathrm{SEM})$ are each based on 4 biological replicates. Statistical significance levels are presented relative to the untreated $E V 2$ strain as: $* \mathrm{p}<0.05 ; * * \mathrm{p}<0.01 ; * * * \mathrm{p}<0.001$.

The transcript level of VTC2 increased upon the $2 \mathrm{mM} \mathrm{Na-Asc} \mathrm{treatment,}$ particularly in the VTC2-A27 transformant (Figure 26 A). We additionally measured the time dependence of these transcript changes and detected significant changes 
already $15 \mathrm{~min}$ after the addition of $2 \mathrm{mM} \mathrm{Na}$-Asc, with a maximum at $2 \mathrm{~h}$ (Figure $\underline{26 \mathrm{~B}}$ ), confirming that exogenously supplied Asc upregulated VTC2 expression.
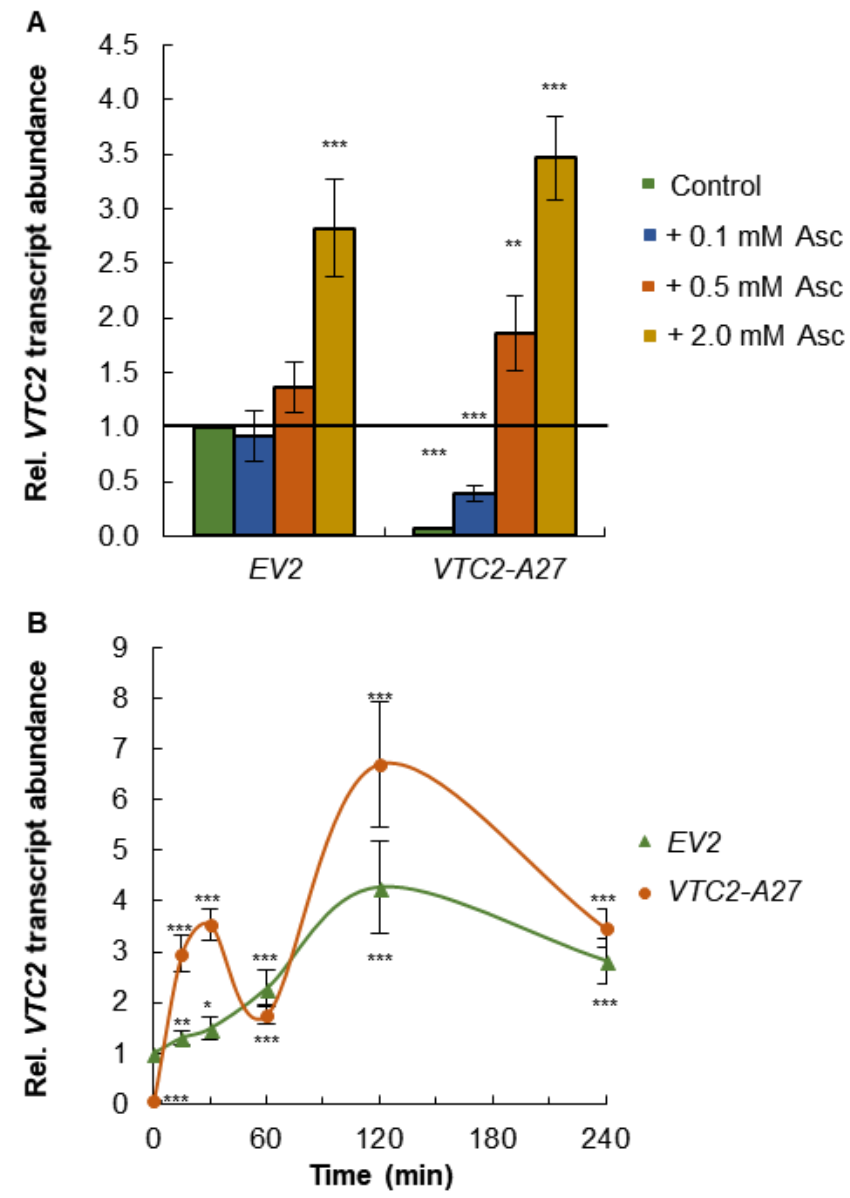

Figure 26. The effects of Asc supplementation on $C$. reinhardtii $E V 2$ and VTC2-A27 strains. (A) VTC2 transcript levels $4 \mathrm{~h}$ after the addition of $0.1,0.5$ and 2 $\mathrm{mM}$ Na-Asc. (B) Time course of VTC2 transcript changes upon addition of $2 \mathrm{mM}$ Na-Asc. Mean values $( \pm$ SEM) are each based on 4 biological replicates. Statistical significance levels are presented relative to the untreated $E V 2$ strain as:

$* \mathrm{p}<0.05 ; * * \mathrm{p}<0.01 ; * * * \mathrm{p}<0.001$.

Our study demonstrates that the regulation of Asc biosynthesis has evolved markedly different mechanisms in C. reinhardtii than in higher plants, allowing rapid changes in a constantly changing environment. We have established that the VTC2 gene of $C$. reinhardtii is not directly regulated by the photosynthetic electron transport chain, albeit there is indirect regulation since the light reactions of photosynthesis represent the main site of ROS production in algal cells. Furthermore, 
in contrast to plants, cellular Asc content is not under circadian control in $C$. reinhardtii and upon oxidative stress, VTC2 transcript abundance is strongly upregulated, thus allowing a very rapid Asc accumulation. Moreover, our results also show the lack of a negative feedback mechanism in the physiological Asc concentration range. In combination, these mechanisms enable a prompt and manifold accumulation of Asc whenever the environmental conditions become unfavorable for C. reinhardtii. 
4.2) Determination of the role of Asc in the inactivation of PSII during sulphur deprivation-induced $\mathrm{H}_{2}$ production in $C$. reinhardtii

Photobiological $\mathrm{H}_{2}$ production is an interesting choice for a potential renewable energy source because it is carried out by microorganisms in an aqueous environment, possibly without arable land requirement (Nagy et al., 2018a). Sulphur deprivation in the green alga $C$. reinhardtii may induce $\mathrm{H}_{2}$ production lasting for several days, which has been proposed to be exploited as a renewable energy source (Melis et al., 2000; Saroussi et al., 2017). Sulphur limitation results in the decline in the expression of a large number of photosynthetic genes, encoding subunits of PSI, PSII and ATPase, whereas the transcript levels of two particular antenna proteins, LHCBM9 and LHCSR1 are upregulated (Nguyen et al., 2011; Toepel et al., 2013). The decline of photosynthetic activity is manifested first in the loss of Rubisco, decreased PSII activity and the degradation of various photosynthetic complexes (Zhang et al., 2002). On the other hand, respiration is maintained, which, together with the loss of PSII activity, results in the establishment of hypoxia, enabling the expression of the highly $\mathrm{O}_{2}$-sensitive [Fe-Fe] type algal hydrogenases (HYDA1 and HYDA2), located on the acceptor side of PSI (Volgusheva et al., 2013; Zhang et al., 2002).

The reduction of PSII activity is an essential step for the initiation of $\mathrm{H}_{2}$ production. It is generally considered that the loss of PSII activity is caused by the limited turnover of the PsbA protein (Antal et al., 2015), because this protein has the highest turnover among all photosynthetic complexes (Nelson et al., 2014). We recently demonstrated that sulphur deprivation also results in a dramatic, about 50-fold, increase in Asc concentration, and that Asc may inactivate the Mn-cluster of the OEC when present in the $\mathrm{mM}$ range (Nagy et al., 2016). Based on these results, we suggested that Asc may contribute to the establishment of hypoxia, and thereby it plays a role in the initiation of $\mathrm{H}_{2}$ production. As a follow-up of this line of researched, we aimed at investigating the inactivation mechanisms of PSII in detail.

\subsection{1) The degradation of photosynthetic complexes during sulphur deprivation}

The PsbA protein has probably the highest turnover rate among all photosynthetic complexes (Järvi et al., 2015), and it is generally supposed that the turnover of PsbA is limited by sulphur availability, responsible for the loss of PSII 
activity (Antal et al., 2015; Volgusheva et al., 2013; Zhang et al., 2002). However, only a moderate, about $25 \%$ (from $2074 \mathrm{ng} / \mathrm{million}$ cells to $1531 \mathrm{ng} / \mathrm{million}$ cells) decrease in sulphur content was observed upon 2 days of sulphur deprivation (measured by Dr. Klára Szentmihályi using ICP-OES at the MTA-TTK Budapest, for more information see Nagy et al., 2018b), which is unlikely to cause substantial PsbA loss upon sulphur deprivation alone. In order to investigate the degradation of PsbA and other photosynthetic complexes in detail, western blot analysis was carried out.

Upon sulphur deprivation, the PsbA content decreased steadily (Figure $27 \mathrm{~A}$, B), with about $30 \%$ remaining by $96 \mathrm{~h}$ of sulphur deprivation. The loss of PsbA occurred in parallel with the loss of PSBO (Figure $27 \mathrm{~A}, \mathrm{C}$ ), the major subunit of the OEC. The level of CP43, an inner antenna complex stabilizing PSII (Sugimoto and Takahashi, 2003), decreased rapidly, with a half-life time of less than $24 \mathrm{~h}$ (Figure 27 $\underline{A, D})$. As expected based on earlier studies, the cytb ${ }_{6}$ f subunit, PetB, and the reaction center core of PSI, PsaA, were better retained (Figure $27 \mathrm{~A}, \mathrm{E}, \mathrm{F})$. The level of RbcL, the large subunit of Rubisco, decreased more rapidly (Figure $27 \mathrm{~A}, \mathrm{G}$ ), in line with the literature data indicating that the inactivation of Rubisco is one of the earliest responses to sulphur limitation (Antal et al., 2015).

In the presence of lincomycin (LM), which inhibits the synthesis of chloroplast-encoded proteins, the level of PsbA rapidly dropped (with half-life times of approximately 55 and $17 \mathrm{~h}$ in the absence and presence of LM, respectively), whereas the levels of RbcL, PetB, CP43 and PsaA were only moderately decreased upon LM treatment of the sulphur-limited cultures (Figure 27). The $\mathrm{F}_{\mathrm{V}} / \mathrm{F}_{\mathrm{M}}$ parameter, an indicator of maximal quantum efficiency of PSII (Schansker et al., 2014), also shows that upon the addition of LM the photosynthetic activity declined more rapidly than in its absence (Figure $27 \mathrm{H}$ ). These data show that there was a substantial turnover of PsbA upon sulphur deprivation, and it remained at a relatively high level compared with several other chloroplast-encoded photosynthetic subunits. 
(a)

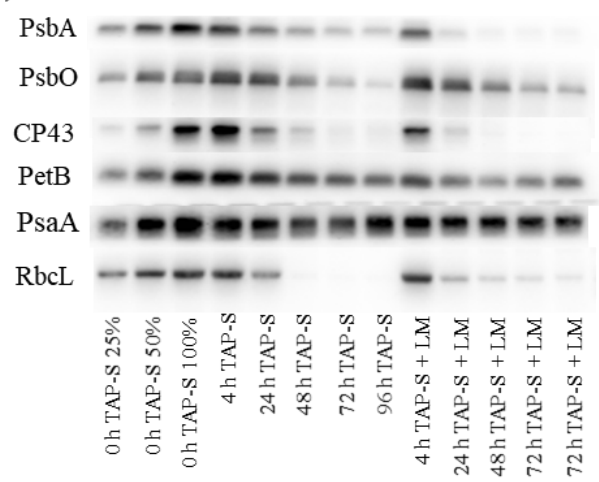

(c)

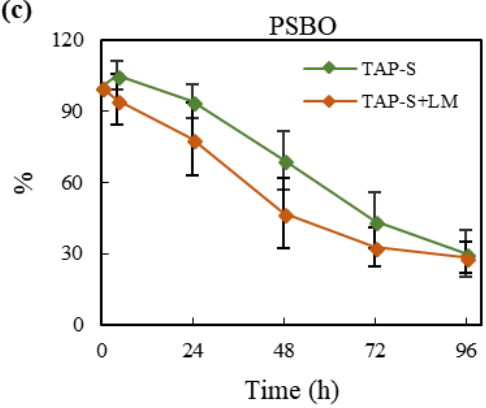

(e)

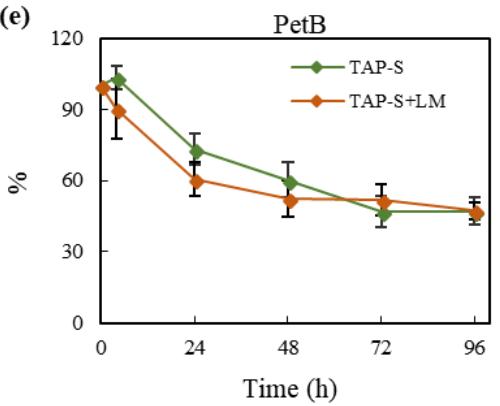

(g)

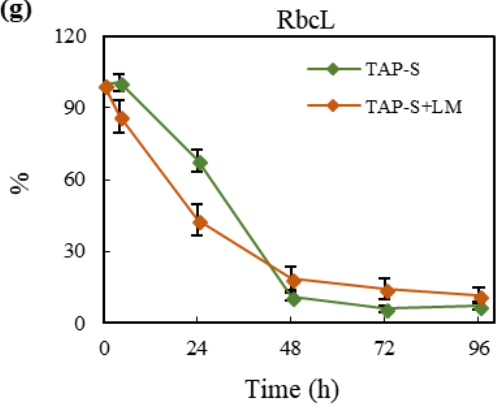

(b)

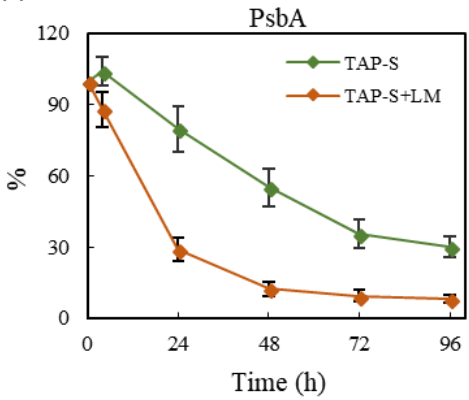

(d)

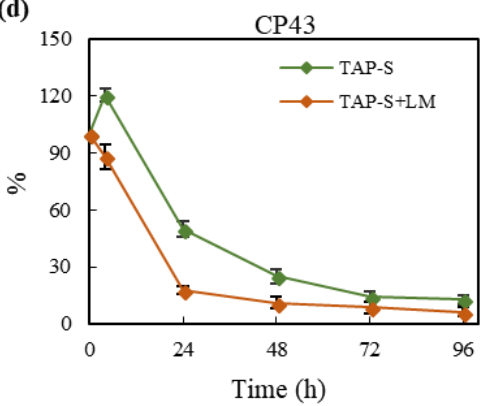

(f)

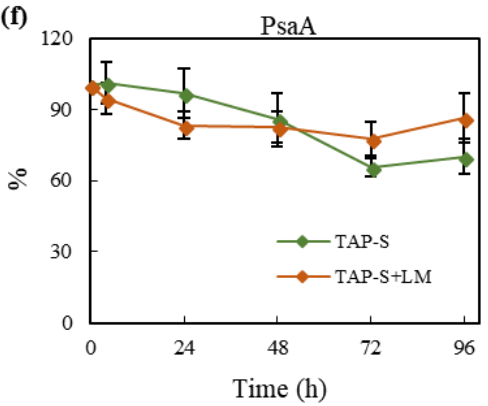

(h)

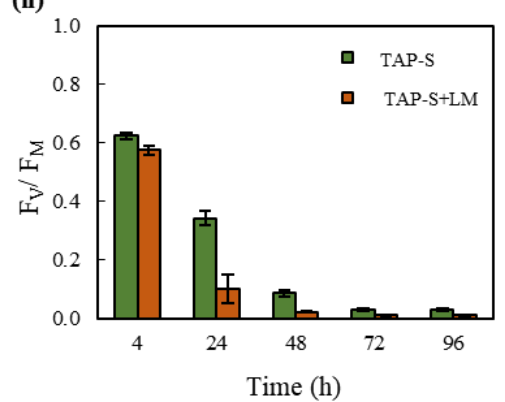

Figure 27. Degradation of photosynthetic complexes during sulphur deprivation in $\boldsymbol{C}$. reinhardtii. (a) Western blot analysis for the semi-quantitative determination of PsbA, PSBO, CP43, PetB, PsaA and RbcL contents in sulphurlimited $C$. reinhardtii cultures, in the presence and absence of lincomycin (LM), added following the transfer of cells to sulphur-free TAP media. Samples of $2 \mu \mathrm{g}$ $\mathrm{Chl}(\mathrm{a}+\mathrm{b})$ were loaded and the first to third lanes $(25,50$ and $100 \%$ of $0 \mathrm{~h}$ control) are for the approximate quantitation of the proteins. Densitometry analysis: (b) PsbA; (c) PSBO; (d) CP43; (e) PetB; (f) PsaA; (g) RbcL. (h) Changes of $\mathrm{F}_{\mathrm{V}} / \mathrm{F}_{\mathrm{M}}$ in sulphurlimited cultures in the presence and absence of LM. Mean values $( \pm$ SEM) are each based on between three to six biological replicates. 
4.2.2) GDP-L-galactose phosphorylase is induced upon sulphur deprivation

In our previous paper, we demonstrated that Asc accumulates drastically upon sulphur deprivation (Nagy et al., 2016). The VTC2 gene, encoding GDP-L-galactose phosphorylase, plays an essential regulatory role in Asc biosynthesis (Urzica et al., 2012; Vidal-Meireles et al., 2017, see previous chapter). Figure 28 A shows that there was an approximately seven-fold increase in its expression upon sulphur deprivation, correlating well with the increase in Asc content (Figure 28 B). Upon stress effects, VTC2 expression and thereby Asc accumulation are induced both by ${ }^{1} \mathrm{O}_{2}$ and by $\mathrm{H}_{2} \mathrm{O}_{2}$ (Vidal-Meireles et al., 2017, see previous chapter), which are produced mostly within PSII and at the acceptor side of PSI, respectively (Asada, 2006; Vass, 2012). To ascertain that oxidative stress occurred upon sulphur deprivation, which may lead to the induction of Asc biosynthesis, we investigated the expression of several genes that are known to respond to $\mathrm{H}_{2} \mathrm{O}_{2}$ and ${ }^{1} \mathrm{O}_{2}$.

(a)

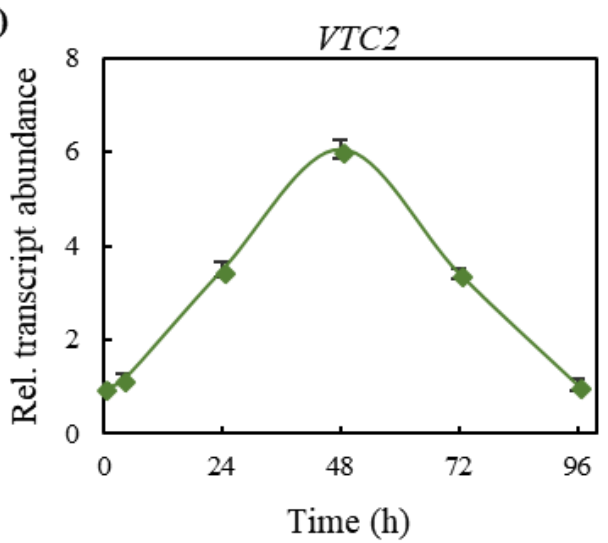

(b)

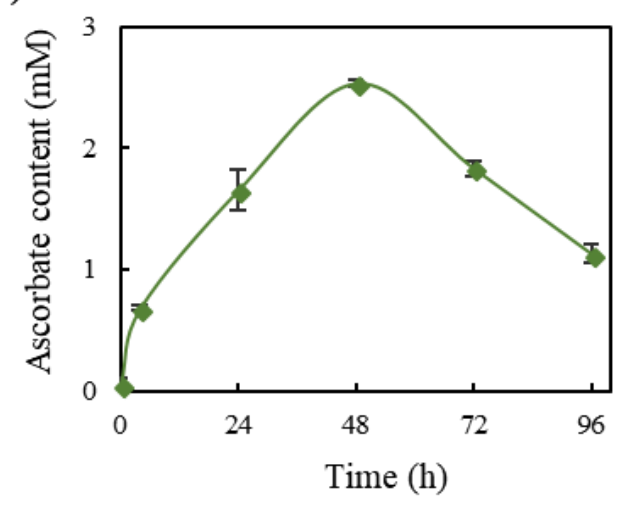

Figure 28. Asc accumulation upon sulphur deprivation in $C$. reinhardtii. (a) Transcript level of $V T C 2$ as determined by real-time qPCR upon sulphur deprivation. (b) Changes in cellular Asc content in C. reinhardtii subjected to sulphur limitation. Mean values $( \pm$ SEM) are each based on between three to six biological replicates.

Glutathione peroxidases (GPXs) and transferases are key enzymes in oxidative stress defense: its Chlamydomonas homologs GPXH and GSTS1/2 have been shown to respond promptly to ${ }^{1} \mathrm{O}_{2}$, and on a longer timescale GSTS1 also responds to $\mathrm{H}_{2} \mathrm{O}_{2}$ (Ledford et al., 2007). Figure 29 A, B shows that GPXH and 
GSTS1 are strongly induced by $48 \mathrm{~h}$ of the experiment, when the VTC2 transcript abundance is at its maximum (Figure $28 \mathrm{~A}$ ).

The enzymes of the Asc-glutathione cycle play essential roles in ROS detoxification (Asada, 2006). The relative transcript abundance of APX1 increased significantly (Figure 29 C) in parallel with VTC2 expression. HSP70A expression has been shown to respond mainly to $\mathrm{H}_{2} \mathrm{O}_{2}$ stress (Leisinger et al., 2001), and its expression was moderately elevated throughout the experiment (Figure 29 D). The relative transcript abundance of the iron-containing superoxide dismutase FSD1 responds both to $\mathrm{H}_{2} \mathrm{O}_{2}$ and to ${ }^{1} \mathrm{O}_{2}$ (Leisinger et al., 2001): the 10-fold increase in FSD1 corroborates the hypothesis that oxidative stress occurs with sulphur deprivation (Figure 29 E).

When measuring the level of intracellular $\mathrm{H}_{2} \mathrm{O}_{2}$, we found a steady decrease throughout the experiment (Figure 29 F). This can be explained by the reduced photosynthetic electron flow to PSI upon sulphur deprivation (Wykoff et al., 1998), resulting in less superoxide and $\mathrm{H}_{2} \mathrm{O}_{2}$ production. On the other hand, ${ }^{1} \mathrm{O}_{2}$ is more likely to accumulate upon sulphur deprivation, because initially the rate of PSII excitation exceeds the rate of linear electron transport (Antal et al., 2015). ${ }^{1} \mathrm{O}_{2}$ is a short-lived species: therefore, quantifying its level in situ is a challenging task. The rate of ${ }^{1} \mathrm{O}_{2}$ production can be measured in cyanobacteria in the presence of histidine, an efficient ${ }^{1} \mathrm{O}_{2}$ quencher, resulting in $\mathrm{O}_{2}$ uptake (Rehman et al., 2013); however, this method is not established for green algae, possibly because of insufficient histidine uptake. 
(a)

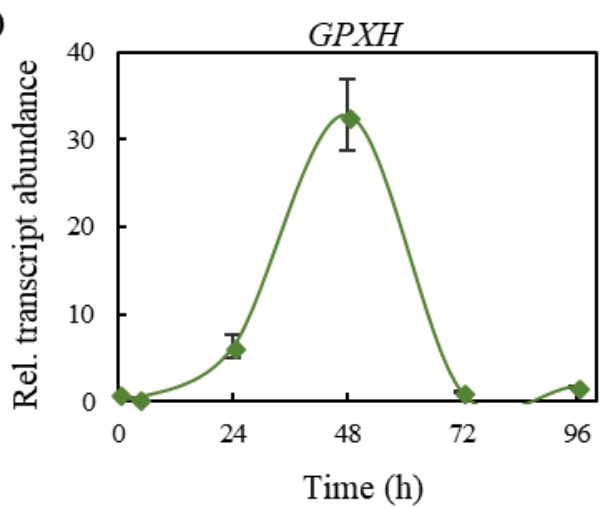

(c)

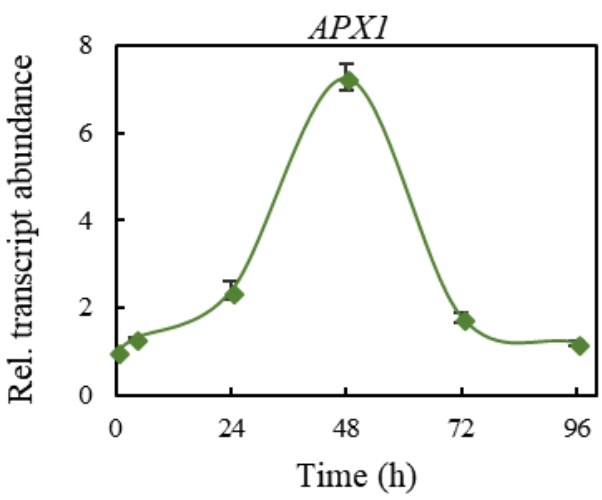

(e)

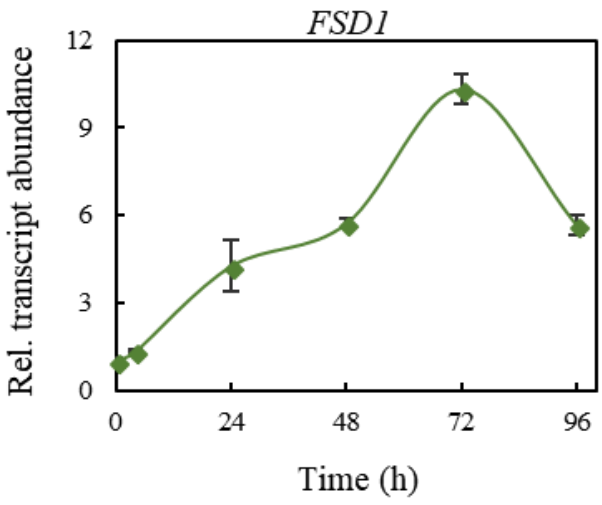

(b)

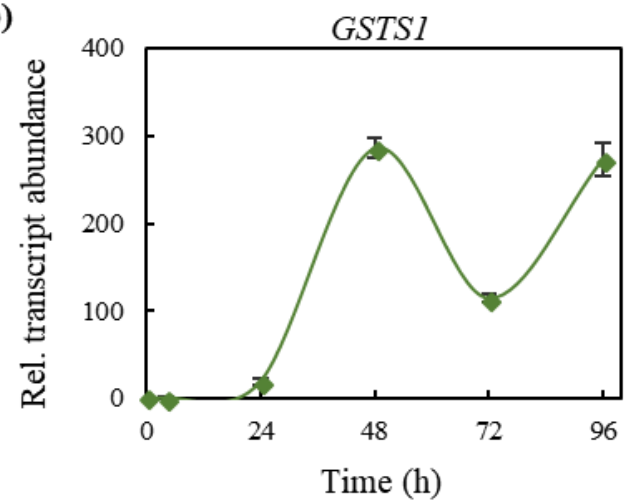

(d)

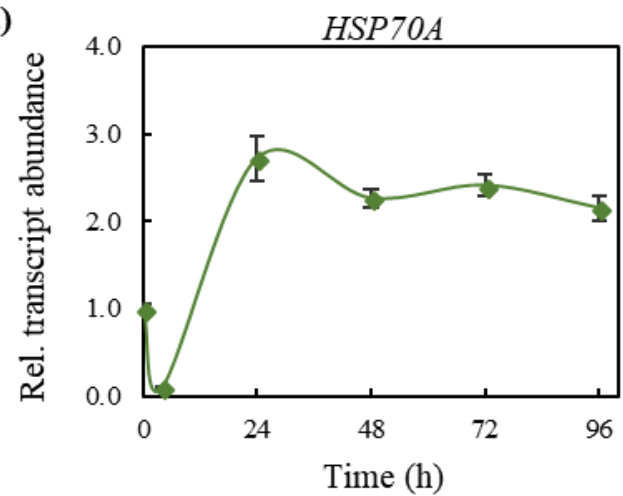

(f)

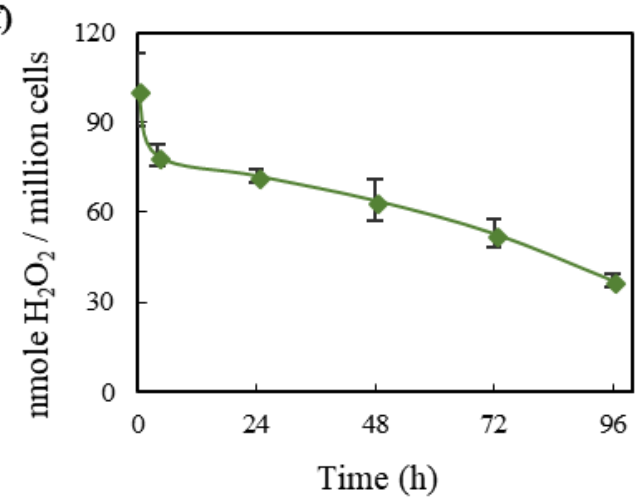

Figure 29. Oxidative stress induced by sulphur limitation in $C$. reinhardtii. (a) Transcript level of the reactive oxygen species-responsive gene GPXH, as determined by real-time qPCR upon sulphur deprivation; (b) GSTS1; (c) APXI; (d) HSP70A; (e) FSD1. (f) Changes in $\mathrm{H}_{2} \mathrm{O}_{2}$ content upon sulphur limitation in $C$. reinhardtii. Mean values $( \pm \mathrm{SEM})$ are each based on three biological replicates.

\subsection{3) The decline of PSII activity may involve donor-side induced}

\section{photoinhibition}

We suggested earlier that Asc, at a high concentration reached after sulphur deprivation, is capable of over-reducing the Mn cluster (Nagy et al., 2016). Once the 
OEC is inactive, Asc may provide electrons to $\mathrm{Tyr}_{\mathrm{z}}^{+}$at a slow rate, which cannot fully prevent the accumulation of strongly oxidizing species in PSII. This so-called donor-side induced photoinhibition process results in the losses of PsbA, PSBO, CP43 and other components of PSII (Arató et al., 2004; Blubaugh et al., 1991; Jegerschöld and Styring, 1996; Tóth et al., 2011). We note that donor-side induced photoinhibition has been shown to occur in vivo in leaves with heat-inactivated OECs (Tóth et al., 2009, 2011), and it may also occur upon UV-B stress (Mano et al., 2004). The donor-side-induced photoinhibition caused by excessive Asc accumulation was investigated here in detail.

When $20 \mathrm{mM}$ Asc was added to sulphur-replete Chlamydomonas cells and the cultures were incubated for $30 \mathrm{~min}$ in light, the intensity of the $\mathrm{B}$ thermoluminescence band, originated from the $\mathrm{S}_{1} \mathrm{~S}_{2}-\mathrm{QB}^{-}$recombination (Ducruet and Vass, 2009) decreased by approximately 30\% (Figure 30 A), confirming that Asc, when present in the $\mathrm{mM}$ range, over-reduces the Mn cluster in Chlamydomonas (Nagy et al., 2016). As also shown in our previous paper, there is a continuous decrease in the amplitude of the B thermoluminescence band during sulphur deprivation, and within $48 \mathrm{~h}$ the $\mathrm{B}$ band is lost (Figure $30 \mathrm{~B}$ ).

(a)

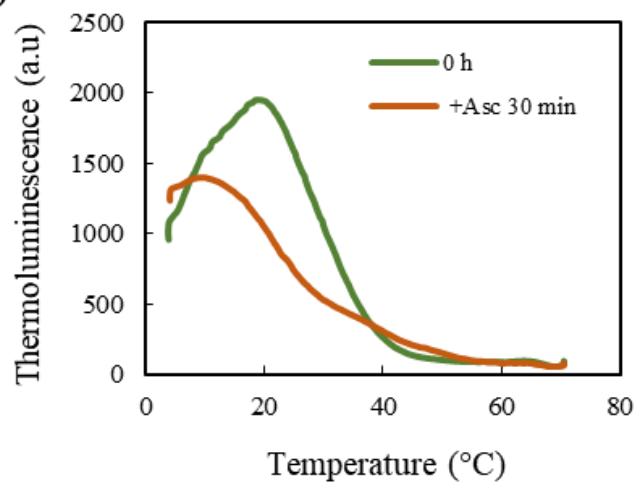

(b)

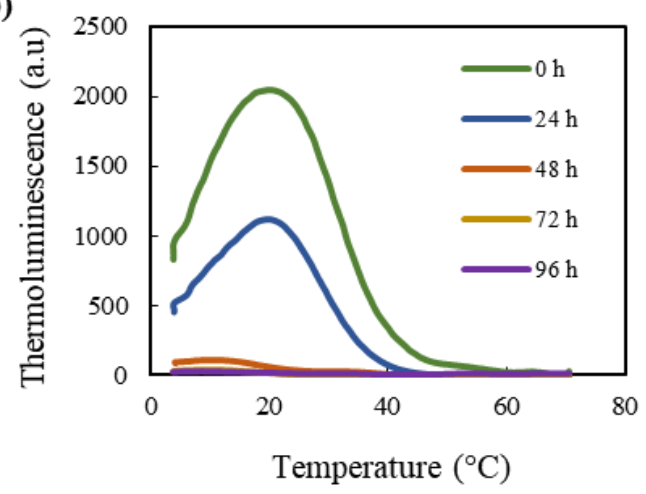

Figure 30. Thermoluminescence emission of $C$. reinhardtii upon excitation with one single turnover flash at $4^{\circ} \mathrm{C}$. (a) The effect of externally provided $20 \mathrm{mM}$ Asc on the B thermoluminescence band; (b) The diminishment of the $\mathrm{B}$ band upon sulphur deprivation. Mean values $( \pm \mathrm{SEM})$ are each based on three biological replicates.

In order to obtain direct evidence for donor-side-induced photoinhibition, we measured oxygen uptake on isolated thylakoid membranes of $C$. reinhardtii in the presence of MV, as a terminal electron acceptor at PSI (Izawa, 1980) and DPC, an 
efficient electron donor to $\operatorname{Tyr}_{\mathrm{z}}{ }^{+}$(Rashid and Popovic, 1995). As Asc is lost during the thylakoid isolation process (Ivanov and Edwards, 2000), and DPC can supply electrons to PSII without damaging the active OECs, and at a high rate (Rashid and Popovic, 1995), the presence of PSII reaction centers with inactive OECs can be assessed by this approach. Figure $31 \mathrm{~A}$ shows that upon sulphur deprivation the rate of MV-dependent $\mathrm{O}_{2}$ uptake steadily decreased, and by 48-60 h a minimum was reached, which coincides with the complete loss of the B thermoluminescence band (Figure $31 \mathrm{~B}$ ), suggesting that the number of PSII units with active OECs strongly decreased.

In the presence of DPC, which supplies electrons to PSII without damaging it, the rate of $\mathrm{O}_{2}$ uptake was higher than in its absence, demonstrating the existence of PSII reaction centers, which are capable of charge separations but lack $\mathrm{O}_{2}$-evolving activity. In untreated, sulphur-replete cells, the addition of DPC resulted in a $30 \%$ increase in $\mathrm{O}_{2}$ uptake (Figure $31 \mathrm{~B}$ ), which might be caused by a partial loss of OEC activity upon thylakoid isolation, and/or the presence of PSII reaction centers without OEC in vivo. Upon sulphur deprivation, DPC-dependent $\mathrm{O}_{2}$ uptake increased considerably relative to the control, by a maximum of about $100 \%$ (Figure $31 \mathrm{~B}$ ) at the $48 \mathrm{~h}$ time point, when the B band was already absent (Figure $31 \mathrm{~B}$ ). These results demonstrate that the number of PSII reaction centers without active OECs, relative to fully active PSII units, increased upon sulphur deprivation, supporting our hypothesis that upon sulphur deprivation the inactivation of PSII involves donor-side-induced photoinhibition.

(a)

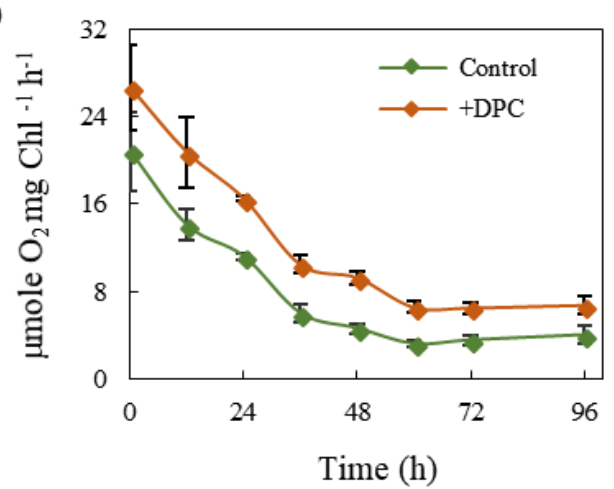

(b)

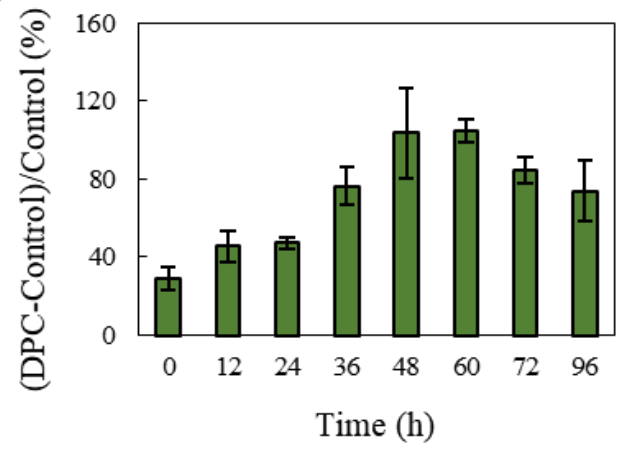

Figure 31. Changes in the rate of $\mathrm{MV}$-dependent $\mathrm{O}_{2}$ uptake upon sulphur deprivation of $C$. reinhardtii, as measured in the presence and absence of the artificial PSII electron donor DPC. (a) Rates of $\mathrm{O}_{2}$ uptake. (b) Ratio of $\mathrm{O}_{2}$ uptake rates measured in the presence and absence of DPC. Mean values $( \pm$ SEMs $)$ are each based on three biological replicates. 
The responses to sulphur limitation in Chlamydomonas include maximizing the uptake of sulphur from the environment, minimizing the decrease in cellular sulphur content via cell division arrest, increasing starch and Asc biosynthesis, inactivation of the OEC, PSII reaction centers inactivation and degradation, and finally establishment of hypoxia enabling hydrogenase expression $\left(\mathrm{H}_{2}\right.$ production acts as a safety valve of the photosynthetic electron transport). Sulphur deprivation has been a method of choice for many years to induce $\mathrm{H}_{2}$ production in $C$. reinhardtii; however, as outlined here, this type of $\mathrm{H}_{2}$ production involves the complete remodeling of cellular metabolism, including the degradation of the photosynthetic apparatus and, in addition, it is also largely dependent on acetate as an organic carbon source. For these reasons, other, alternative methods, are preferred that may allow the industrial exploitation of the $\mathrm{H}_{2}$ production capacity of $C$. reinhardtii in the future. 


\section{3) Determination of the role of Asc in the induction of NPQ}

Ascorbate plays an important role as a cofactor of VDE (Müller-Moulé et al., 2002; Smirnoff, 2000). This enzyme is activated by low thylakoid luminal $\mathrm{pH}$ and it is responsible for the conversion of violaxanthin to zeaxanthin. By this means, VDE plays an essential role in NPQ, a process to dissipate excess light energy (MüllerMoulé et al., 2002).

It was recently described that CrVDE differs substantially from the plant-type VDE. It is not homologous to plant VDE, but related to a lycopene cyclase of photosynthetic bacteria and is located on the stromal side of the thylakoid membrane. (Li et al., 2016b). Due to these important differences, we raised the question whether Asc is needed as a cofactor of of CrVDE.

To this end, we characterized a mutant procured from the CLiP library ( $\mathrm{Li}$ et al., 2016a) that is affected in VTC2, encoding GDP-L-galactose phosphorylase, which is a highly regulated enzyme and plays an essential role in Asc biosynthesis (Vidal-Meireles et al., 2017; chapter 4.1).

\subsection{1) Identification and preliminary characterization of the $C$.} reinhardtii VTC2 insertion mutant

To investigate the function of Asc in NPQ in C. reinhardtii, we searched for insertion mutants in the VTC2 (Cre13.g588150) gene region in the CLiP library (Li et al., 2016a). We obtained two putative VTC2 mutants, holding insertion of the paromomycin resistance cassette in the coding region (strain LMJ.RY0402.058624) or in the 3'UTR end (strain LMJ.RY0402.146784) of the gene (Figure $32 \mathrm{~A}$ ).

The site of integration in VTC2 mutant in the insertional library was validated earlier by LEAP-Seq method, with an insertion confidence of 95\% (Li et al., 2016a). Validation of the VTC2 mutant strain was also carried out by us through PCR using gene specific primers against the $V T C 2$ gene. A specific $0.7 \mathrm{~kb}$ fragment, used as a DNA isolation control, was observed by PCR using genomic DNA isolated from WT Chlamydomonas cells (CC-4533) and it was present in the mutant strain (Figure 32 B); when the gene specific primers were designed to include the cassette insertion sites, the specific $1.1 \mathrm{~kb}$ fragment was observed by PCR only in the DNA isolated from the WT cells, but it was absent in the mutant strain (Figure $32 \mathrm{C}$ ). 
(a)

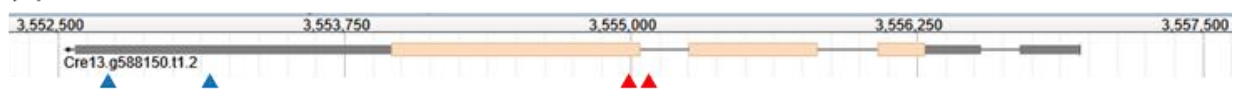

(b)

(c)
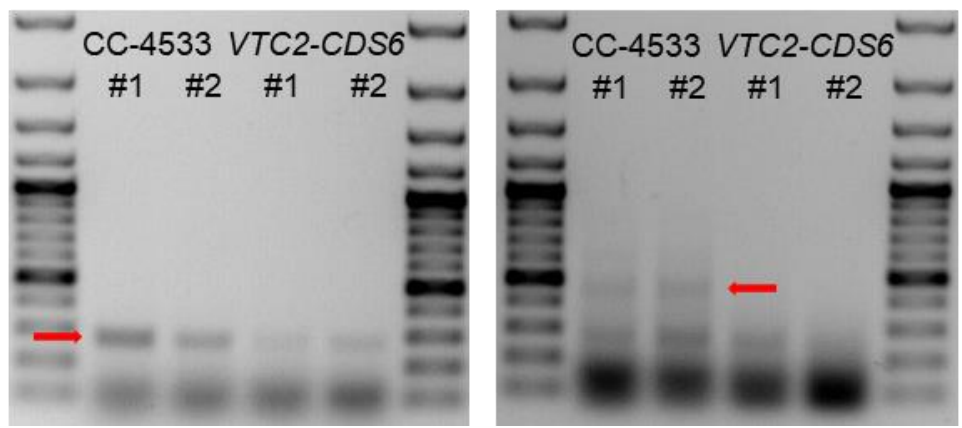

Figure 32. Characterization of the $C$. reinhardtii VTC2 insertion mutant strains. (a) Scheme of the VTC2 gene (obtained from Phytozome v12.1.6) with the cassette insertion sites marked with blue (LMJ.RY0402.146784) or red (LMJ.RY0402.058624) triangles. (b) PCR test for the VTC2 gene in a region before the predicted cassette insertion sites, with the expected product marked with a red arrow; (c) PCR test for the VTC2 gene including the predicted cassette insertion sites, with the expected product marked with a red arrow.

One of the two putative $V T C 2$ mutant targeting the coding regions, hereafter called VTC2-CDS6, showed a very strong decrease in Asc content: under normal growth conditions, its Asc content was approx. $80 \%$ lower than that of the wild-type (Figure $33 \mathrm{~A}$ ). When the wild type and the VTC2 mutant were treated with $1.5 \mathrm{mM}$ $\mathrm{H}_{2} \mathrm{O}_{2}$, which was shown to result in a strong increase in Asc content (Urzica et al., 2012; Vidal-Meireles et al., 2017; section 4.1.2), the Asc content in the WT increased approximately 4-fold, whereas the VTC2 mutant did not show significant increase in its Asc content (Figure $33 \mathrm{~A}$ ). This is in contrast with the VTC2-amiRNA lines used in our previous study, where $\mathrm{H}_{2} \mathrm{O}_{2}$ treatment resulted in remarkable Asc accumulation (Vidal-Meireles et al., 2017; section 4.1.2).

Using qRT-PCR analysis with primers located near the insertion sites, no VTC2 transcript could be detected under normal growth conditions for the Ascdeficient mutant (Figure $33 \mathrm{~B}$ ); upon $\mathrm{H}_{2} \mathrm{O}_{2}$ treatment, some VTC2 transcript was present (Figure $33 \mathrm{~B})$. 
(a)

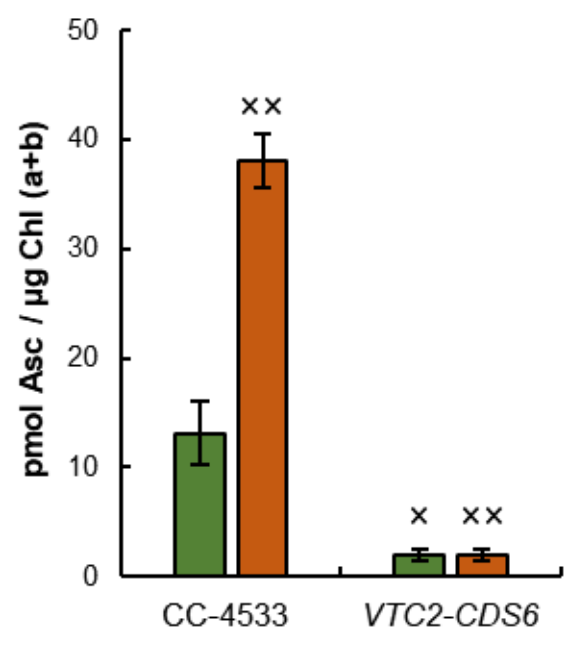

(b)

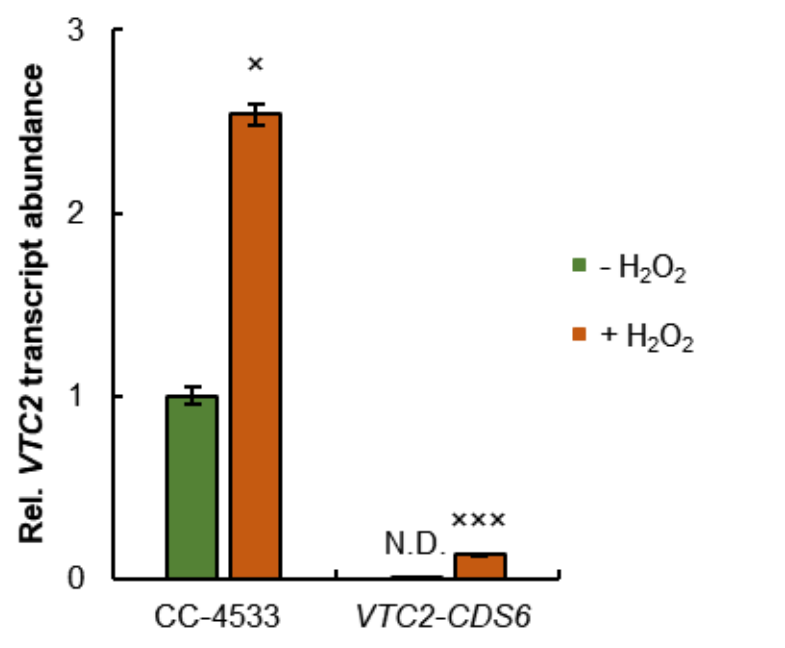

Figure 33. The effects of $1.5 \mathrm{mM} \mathrm{H}_{2} \mathrm{O}_{2}$ in the CC-4533 and VTC2-CDS6 strains of $\boldsymbol{C}$. reinhardtii. (a) Asc contents of the cultures grown under normal light $\left(80 \mu\right.$ mole photons $\left.\mathrm{m}^{-2} \mathrm{~s}^{-1}\right)$; (b) Transcript levels of VTC2 as determined by real-time qPCR. Statistical significance levels are presented relative to the untreated CC-4533 strain as: $\times \mathrm{p}<0.05 ; \times \times \mathrm{p}<0.01 ; \times \times \times \mathrm{p}<0.001$. N.D. stands for Not detectable.

The insertional mutant possessed a $30 \%$ decrease in photosynthetic electron transport rate (ETR(II)), which could be efficiently restored by $1 \mathrm{mM} \mathrm{Asc}$ supplementation (Figure $34 \mathrm{~A}$ ). Asc deficiency also affected the kinetics of the fast Chl $a$ fluorescence transient, with the largest difference being a remarkable increase at $2 \mathrm{~ms}$ (the so-called $\mathrm{J}$ step) and a slight increase of $\mathrm{F}_{0}$ (Figure $34 \mathrm{~B}$ ), indicating that the PQ pool was in a more reduced state (Tóth et al., 2007) in the Asc-deficient mutant than in the wild-type. When the cultures were incubated for $2 \mathrm{~h}$ in the presence of $1 \mathrm{mM}$ Asc, these differences were largely attenuated (Figure 34). These results are in agreement with our previous study (Vidal-Meireles et al., 2017). However, the VTC2-CDS6 mutant was not affected in Chl content nor in the $\mathrm{Chl} \mathrm{a} / \mathrm{b}$ ratio and cell size (Figure 35) in contrast to our VTC2-amiRNA lines (Vidal-Meireles et al., 2017; section 4.1.3).

Following this initial characterization, the WT and the VTC2 insertion mutant strains were subjected to growth at different conditions in order to study their NPQ processes in detail: i) growth at normal light intensity $\left(100 \mu\right.$ mole photons $\left.\mathrm{m}^{-2} \mathrm{~s}^{-1}\right)$ under photomixotrophic (in TAP medium) or photoautotrophic (in HSM medium) conditions, and ii) growth at high light intensity $\left(530 \mu\right.$ mole photons $\left.\mathrm{m}^{-2} \mathrm{~s}^{-1}\right)$ in HSM medium. For comparison, the well-described $N P Q 1, N P Q 4$ and stt7 mutants were also used in certain experiments (Anwaruzzaman et al., 2004; Ballottari et al., 2016; 
Depege, 2003; Finazzi, 2002; Fleischmann et al., 1999; Lemeille et al., 2010; Niyogi, 1997; Peers et al., 2009).

(a)

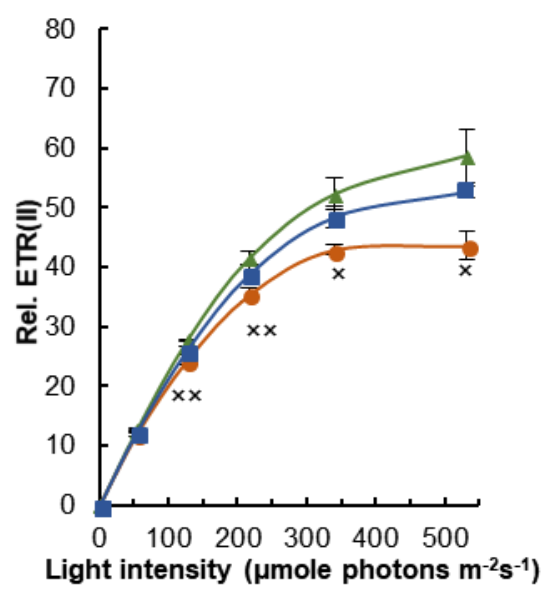

(b)

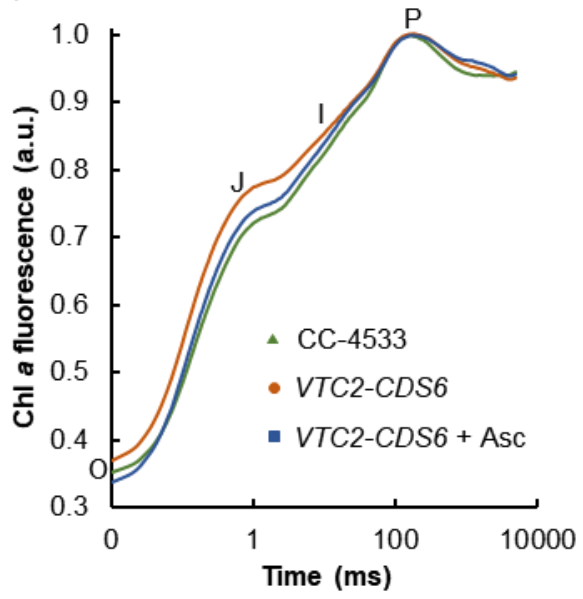

Figure 34. The photosynthetic performance of $C$. reinhardtii $\mathrm{CC}-4533$ and VTC2-CDS6 strains with or without the addition of $1 \mathrm{mM} \mathrm{Na}$-Asc and incubation for $\mathbf{2} \mathbf{h}$ at growth light intensity. (a) Photosynthetic electron transport rates for PSII (relative ETR(II)); (b) Chl $a$ fluorescence transient normalized to its maximum $\left(\mathrm{P}\right.$ or $\left.\mathrm{F}_{\mathrm{M}}\right)$. Mean values $( \pm \mathrm{SEM})$ are each based on 3-4 biological replicates. Statistical significance levels are presented relative to the $\mathrm{CC}-4533$ strain as: $\times \mathrm{p}<0.05 ; \times \times \mathrm{p}<0.01$. 

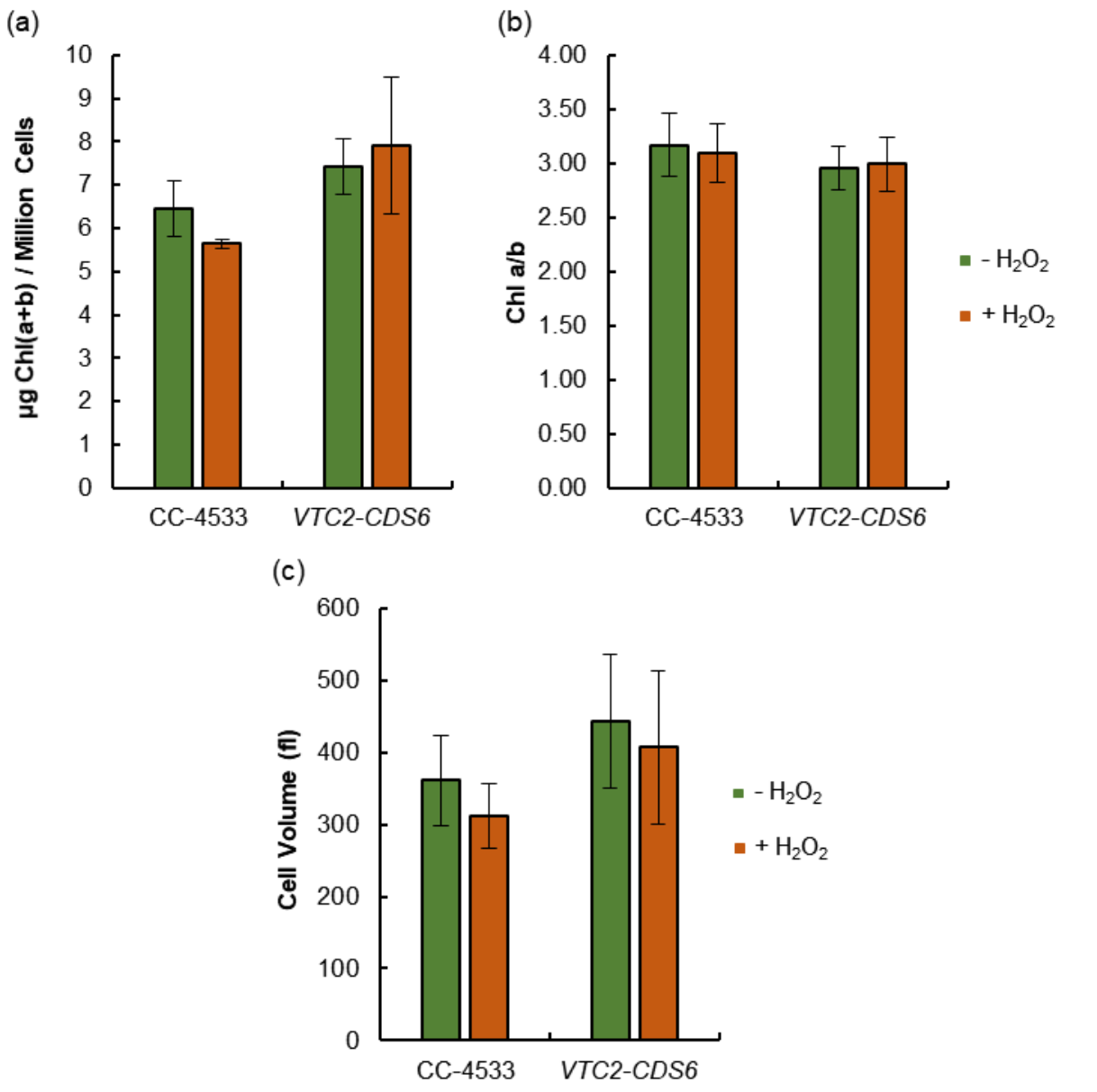

Figure 35. The effects of $1.5 \mathrm{mM} \mathrm{H}_{2} \mathrm{O}_{2}$ in the CC-4533 and VTC2-CDS6 strains of $\boldsymbol{C}$. reinhardtii. (a) $\mathrm{Chl}$ content of the cultures on a cellular basis; (b) $\mathrm{Chl}$ $\mathrm{a} / \mathrm{b}$ ratio; (c) Cell volume.

As a next step, the amounts of several photosynthetic subunits were determined semi-quantitatively, using western blot analysis. Figure 36 shows that the amounts of PsaA, PsbA, PbcL, CP43, PetB and PSBO were essentially unaltered in the case of cultures grown in TAP medium, and the amount of LHCSR3 was approx. $50 \%$ less in the VTC2 mutant relative to the WT strain. Growth in HSM medium at normal light resulted in a decrease in the amounts of the photosynthetic subunits (on a Chl basis), with no remarkable differences between the WT and the VTC2 mutant, and growth at high light intensity led to a very large increase in the amounts of LHCSR3 protein in both strains. 


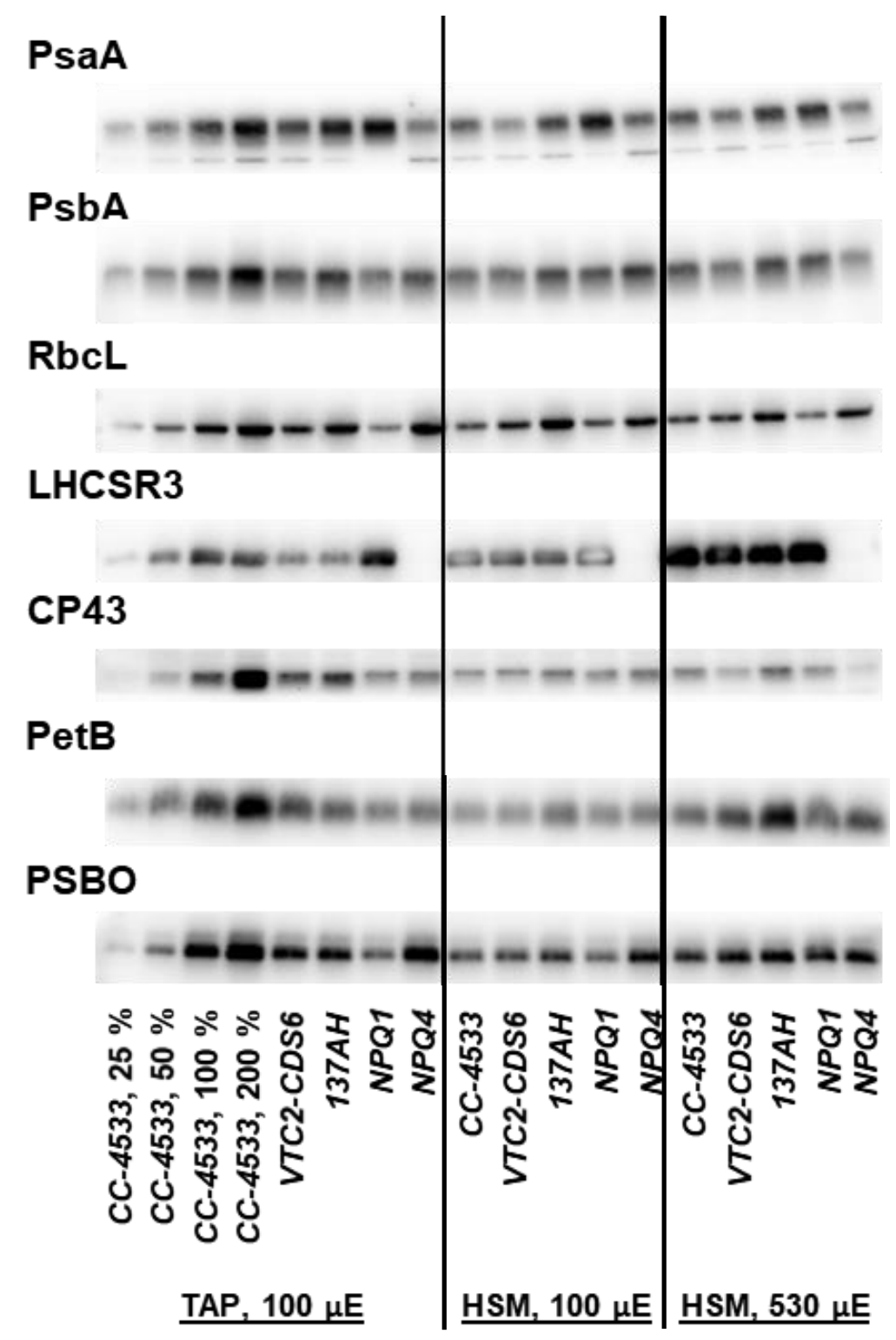

Figure 36. Western blot analysis for the semi-quantitative determination of PsaA, PsbA, RbcL, LHCSR3, CP43, PetB, and PSBO contents in $C$. reinhardtii cultures grown under different conditions. Samples of $1 \mu \mathrm{g} \mathrm{Chl}(\mathrm{a}+\mathrm{b})$ were loaded and the first to fourth lanes $(25,50,100$, and $200 \%$ of CC-4533 grown under photomixotrophic conditions at normal light intensity) are for the approximate quantitation of the proteins. $\mu \mathrm{E}$ stands for $\mu$ mole photons $\mathrm{m}^{-2} \mathrm{~s}^{-1}$.

4.3.2) The effects of Asc deficiency on NPQ in cultures grown under photomixotrophic conditions at normal light

When excitation energy exceeds the capacity for utilization, photoprotective mechanisms may dissipate the excess energy as heat, and the extent of dissipation can be measured via the decrease of Chl $a$ fluorescence during illumination. NPQ includes several, short and long-term mechanisms. In order to assess the effects of 
Asc deficiency on NPQ, cells were grown in TAP medium, at $100 \mu \mathrm{mol}$ photons $\mathrm{m}^{-2}$ $\mathrm{s}^{-1}$. Before the measurements, cultures were dark-adapted for about 30 min with continuous shaking in order to avoid the establishment of anaerobiosis; this darkadaptation period ensures the relaxation of most NPQ processes developed at growth light and the separation of the different NPQ components during illumination (Roach and $\mathrm{Na}, 2017)$.

The $\mathrm{qE}$ component requires the formation of $\Delta \mathrm{pH}$ across the thylakoid membrane; it can be induced in seconds and it relaxes within seconds to minutes. Under normal light conditions, in TAP medium, qE was very small (Figure $37 \mathrm{~A}$ ), in agreement with the literature (Finazzi et al., 2006). A slower component, induced on the timescale of minutes, was also observed, which was enhanced in the Ascdeficient mutant. This effect could also be observed in our VTC2-amiRNA line (Figure 37 B). In order to decipher the origin of the second component, the amounts of various pigments were determined via HPLC. The amounts of violaxanthin, antheraxanthin and zeaxanthin were not affected in the VTC2 mutant, and accordingly, the de-epoxidation indices were also the same in the WT and the mutant throughout the protocol. The light adaptation itself has largely increased the deepoxidation index, which only moderately recovered during the 12 minutes darkrecovery phase (Figure 38). We also found that the amounts of $\beta$-carotene and lutein were not affected by the lack of Asc and their quantities remained constant during the whole protocol (Figure 39). 
(a)

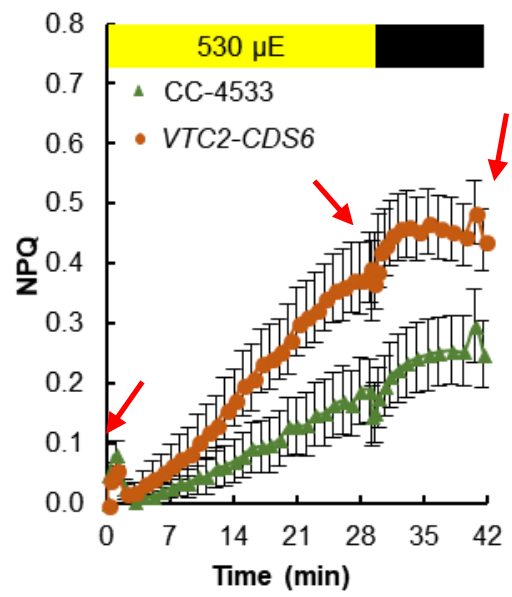

(b)

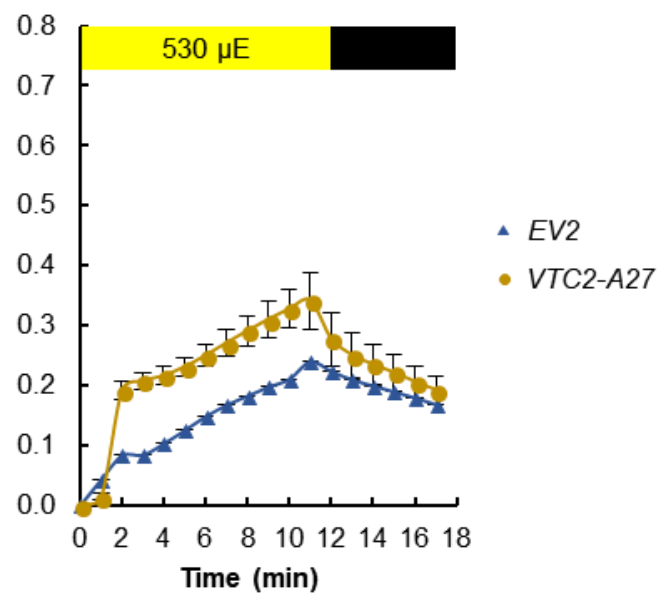

Figure 37. NPQ induction in $C$. reinhardtii grown in TAP medium at 100 $\mu$ mole photons $\mathbf{m}^{-2} \mathbf{s}^{-1}$. (a) CC-4533 and VTC2-CDS6 strains obtained from the CLiP library; (b) EV2 and VTC2-A27 amiRNA strains (Vidal-Meireles et al., 2017). The red arrows mark the sampling points. $\mu \mathrm{E}$ stands for $\mu$ mole photons $\mathrm{m}^{-2} \mathrm{~s}^{-1}$.

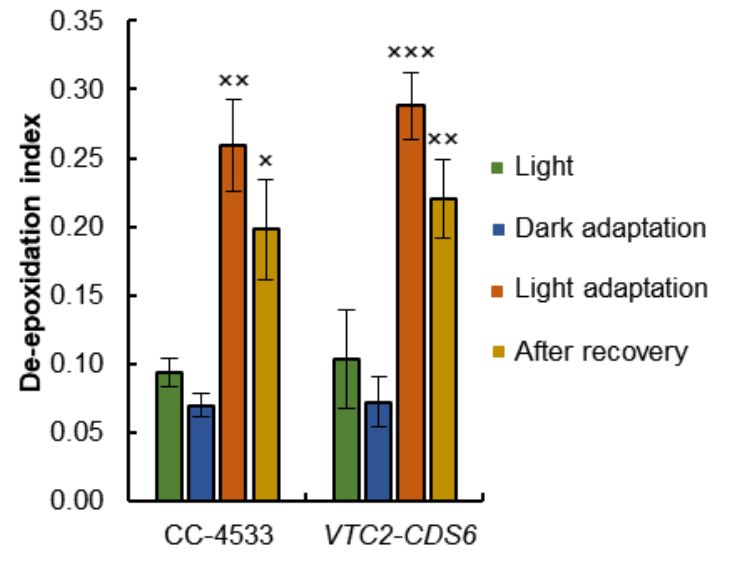

Figure 38. De-epoxidation index of $C$. reinhardtii $\mathrm{CC}-4533$ and VTC2CDS6 strains grown in TAP medium at $100 \mu$ mole photons $\mathbf{m}^{-2} \mathrm{~s}^{-1}$. The samples were collected at several time-points during the NPQ induction protocol. Statistical significance levels are presented relative to the light adapted CC-4533 strain as: $\times \mathrm{p}<0.05 ; \times \times \mathrm{p}<0.01 ; \times \times \times \mathrm{p}<0.001$. 

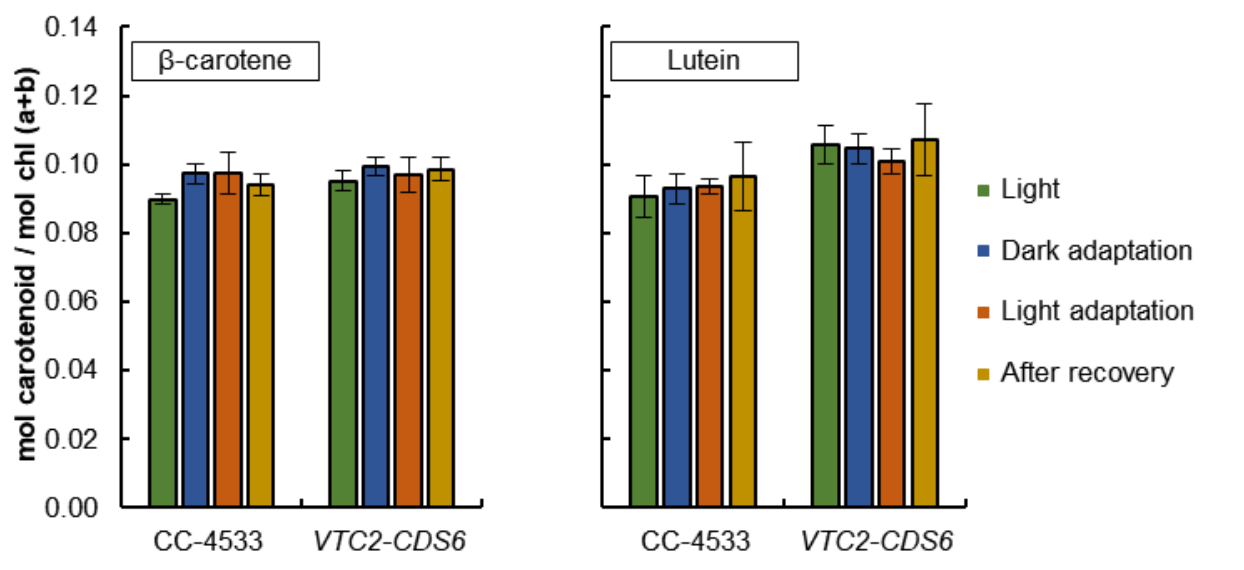

Figure 39. Carotenoid content levels (normalized to $\mathrm{Chl}$ ) of $C$. reinhardtii CC-4533 and VTC2-CDS6 strains grown in TAP medium at 100 $\mu$ mole photons $\mathbf{~ m}^{-2} \mathbf{s}^{-1}$. The samples were collected at several time-points during the NPQ induction protocol.

The increase in the de-epoxidation index suggests that the slow component can be explained by qZ. In order to investigate the contribution of qT in this process, $77 \mathrm{~K}$ fluorescence spectra were recorded. The ratio of $684 \mathrm{~nm} / 710 \mathrm{~nm}$ remained largely unaltered in the WT strain and showed a slight increase in the Asc-deficient mutant (Figure 40), showing that state 1 to state 2 transition did not take place upon illumination. In addition, a state transition mutant, called $s t t 7$ was also tested. Figure $\underline{41 \mathrm{~A}}$ shows that NPQ develops during illumination and HPLC analysis confirms that there is zeaxanthin accumulation in the stt7 mutant during illumination, confirming the independence of the slow component from qT (Figure $41 \mathrm{~B}$ ). 


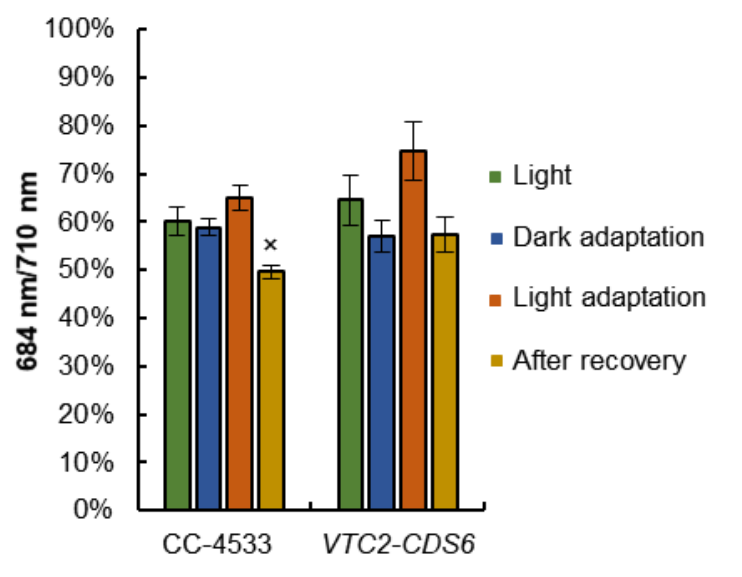

Figure $40.684 \mathrm{~nm} / 710 \mathrm{~nm}$ ratio of the $77 \mathrm{~K}$ fluorescence spectra of $C$. reinhardtii CC-4533 and VTC2-CDS6 strains grown in TAP medium at 100 $\mu$ mole photons $\mathbf{~ m}^{-2} \mathbf{s}^{-1}$. The samples were collected at several time-points during the NPQ induction protocol. Statistical significance levels are presented relative to the light adapted CC-4533 strain as: $\times \mathrm{p}<0.05$

(a)

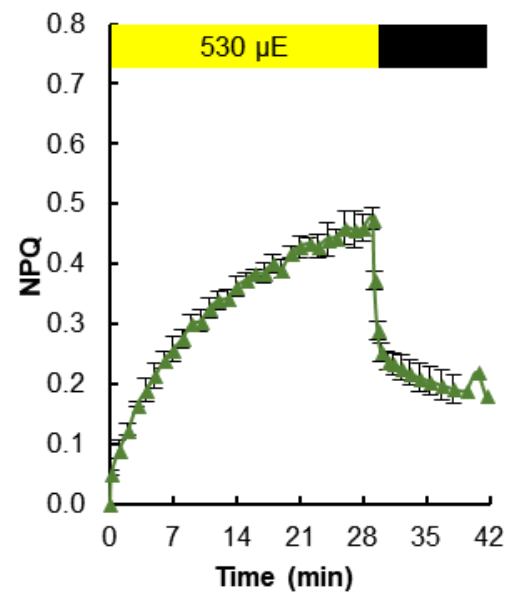

(b)

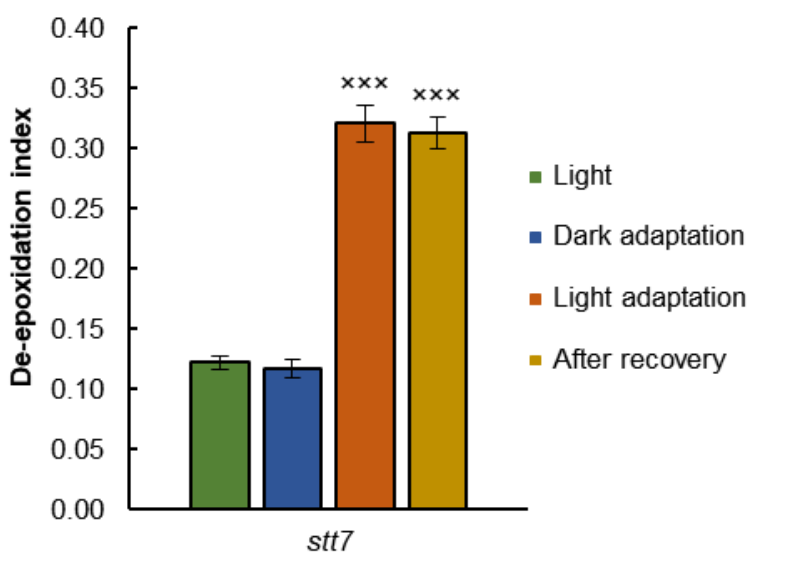

Figure 41. (a) NPQ induction and (b) de-epoxidation index of $C$. reinhardtii stt7 mutant grown in TAP medium at $100 \mu$ mole photons $\mathrm{m}^{-2} \mathrm{~s}^{-1}$. The samples were collected at several time-points during the NPQ induction protocol. Statistical significance levels are presented relative to the light adapted $s t t 7$ strain as: $x \times x p<0.001 . \mu \mathrm{E}$ stands for $\mu$ mole photons $\mathrm{m}^{-2} \mathrm{~s}^{-1}$. 
In addition, the $N P Q 1$ mutant, lacking the CrVDE enzyme, was also tested. Upon illumination with at $530 \mu \mathrm{mol}$ photons $\mathrm{m}^{-2} \mathrm{~s}^{-1}$, this strain developed a large NPQ, which was accompanied with irreversible decrease of $F_{V} / F_{M}$ and loss of Chl and carotenoids (Figure $42 \mathrm{~A}, \mathrm{~B}, \mathrm{C}, \mathrm{D})$. The $N P Q 1$ mutant is unable to perform deepoxidation, and $77 \mathrm{~K}$ fluorescence recordings showed no changes in the $684 \mathrm{~nm} / 710 \mathrm{~nm}$ ratio (Figure $42 \mathrm{E}$ ), thus the large NPQ component could be unambiguously attributed to qI. Interestingly, the amount of Asc in the NPQ1 mutant is very high compared to the other strains (Figure 42 F), probably to compensate for the lack of CrVDE in ROS management. The experiments on the NPQ1 mutant demonstrate the importance of CrVDE upon strong illumination in cultures grown mixotrophically.

These results strongly suggest that CrVDE activity is not limited by Asc deficiency in $C$. reinhardtii. On the contrary, the amplitude of the slow NPQ component was even higher in the VTC2 mutant than in the WT. As a next step, the reason behind this phenomenon was investigated.

The lack of Asc has been shown to result in increased $\mathrm{H}_{2} \mathrm{O}_{2}$ content, probably due to its impaired scavenging (Vidal-Meireles et al., 2017; section 4.1.6) and we hypothesized that $\mathrm{H}_{2} \mathrm{O}_{2}$ may affect NPQ as well. Figure $43 \mathrm{~A}$ shows that upon the addition of $1.5 \mathrm{mM} \mathrm{H}_{2} \mathrm{O}_{2}$, the slow NPQ component has increased remarkably in both strains. When a $5 \mu \mathrm{g} / \mathrm{ml}$ catalase treatment was employed, NPQ significantly decreased in the Asc-deficient mutant (Figure $43 \mathrm{~B}$ ). These data show that $\mathrm{H}_{2} \mathrm{O}_{2}$ might be the reason for the higher NPQ induction in the Asc-deficient mutant, which is expected to constitutively possess higher endogenous ROS even when grown at normal light intensities (Vidal-Meireles et al., 2017). 
(a)

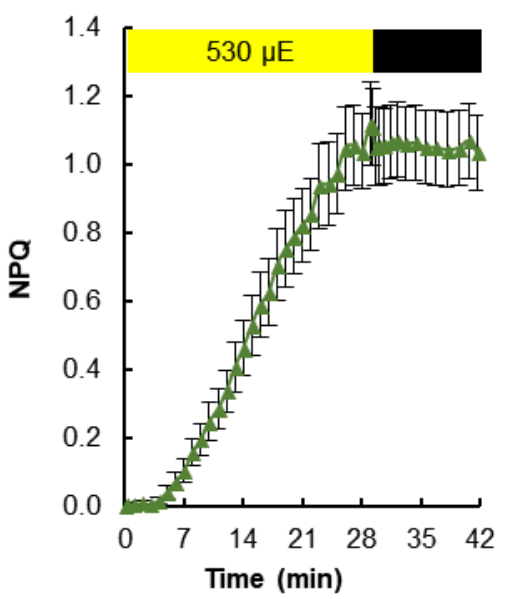

(c)

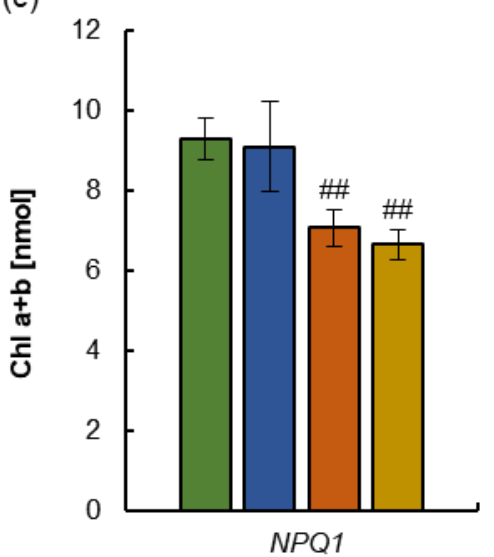

(e)

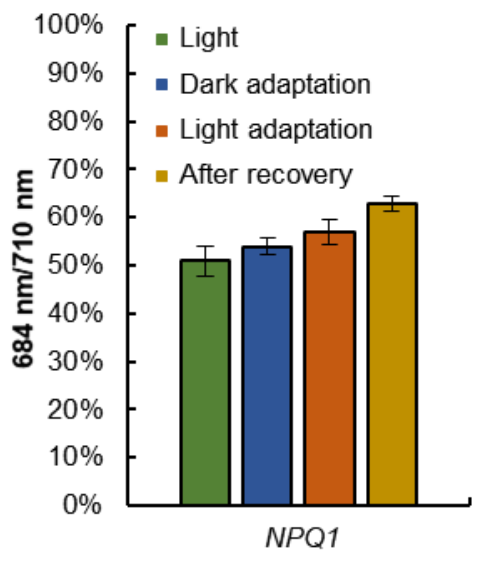

(b)

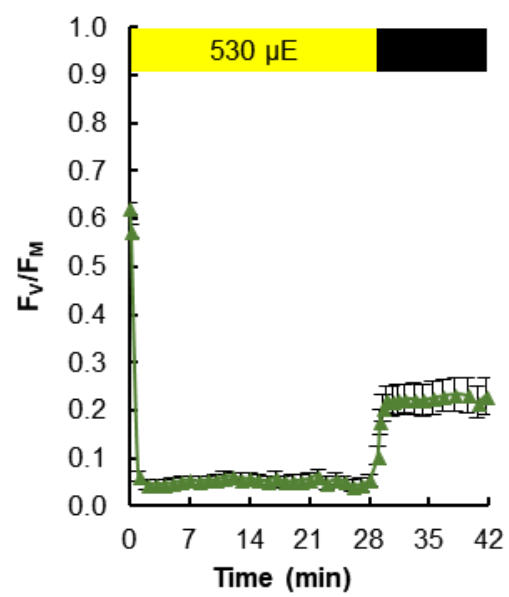

(d)

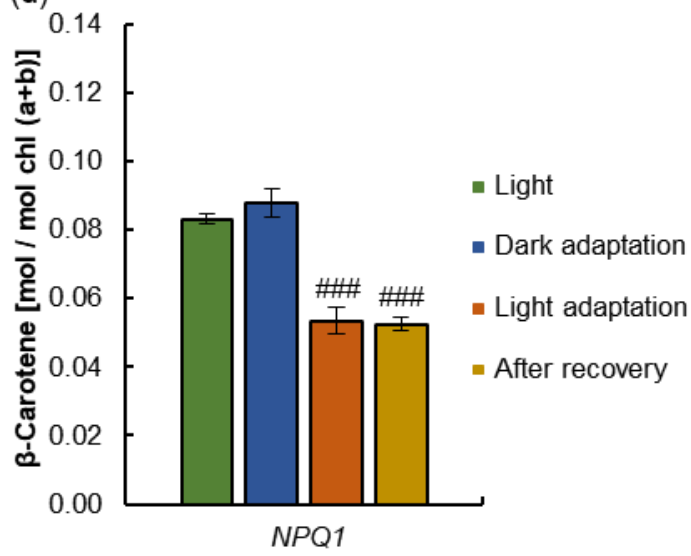

(f)

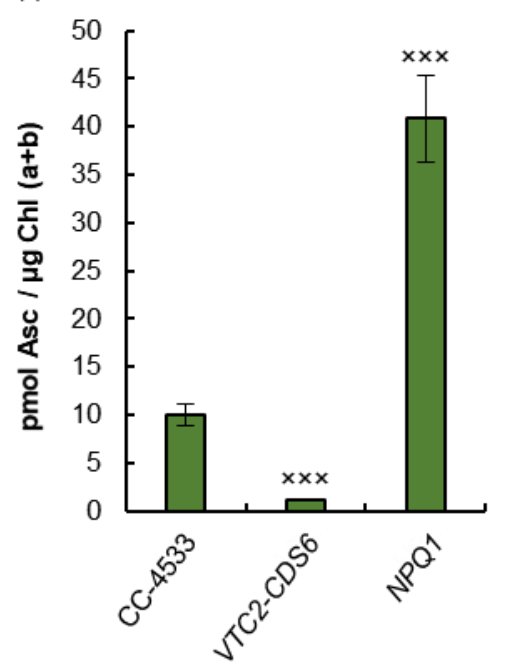

Figure 42. Characterization of the $C$. reinhardtii $N P Q 1$ mutant grown in TAP medium at 100 mole photons $\mathbf{m}^{-2} \mathbf{s}^{-1}$. (a) NPQ induction; (b) $F_{V} / F_{M}$ parameter of the fast $\mathrm{Chl} a$ fluorescence (c) Total Chl content of the cultures; (d) $\beta$ carotene content (normalized to Chl); (e) $684 \mathrm{~nm} / 710 \mathrm{~nm}$ ratio of the $77 \mathrm{~K}$ fluorescence recording; (f) Ascorbate content normalized per Chl content. Statistical significance levels are presented relative to the light adapted $N P Q 1$ strain as: \#\# $\mathrm{p}<0.01$; \#\#\# $\mathrm{p}<0.001$, or relative to the $\mathrm{CC}-4533$ strain as: $x \times \times \mathrm{p}<0.001$. $\mu \mathrm{E}$ stands for $\mu$ mole photons $\mathrm{m}^{-2} \mathrm{~s}^{-1}$. 
(a)
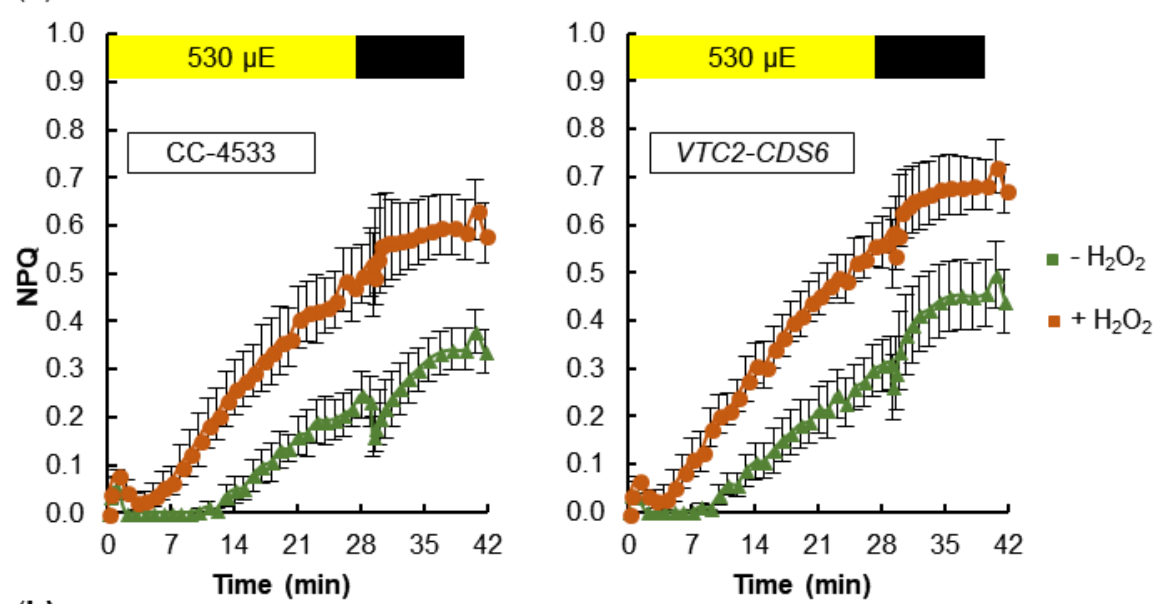

(b)
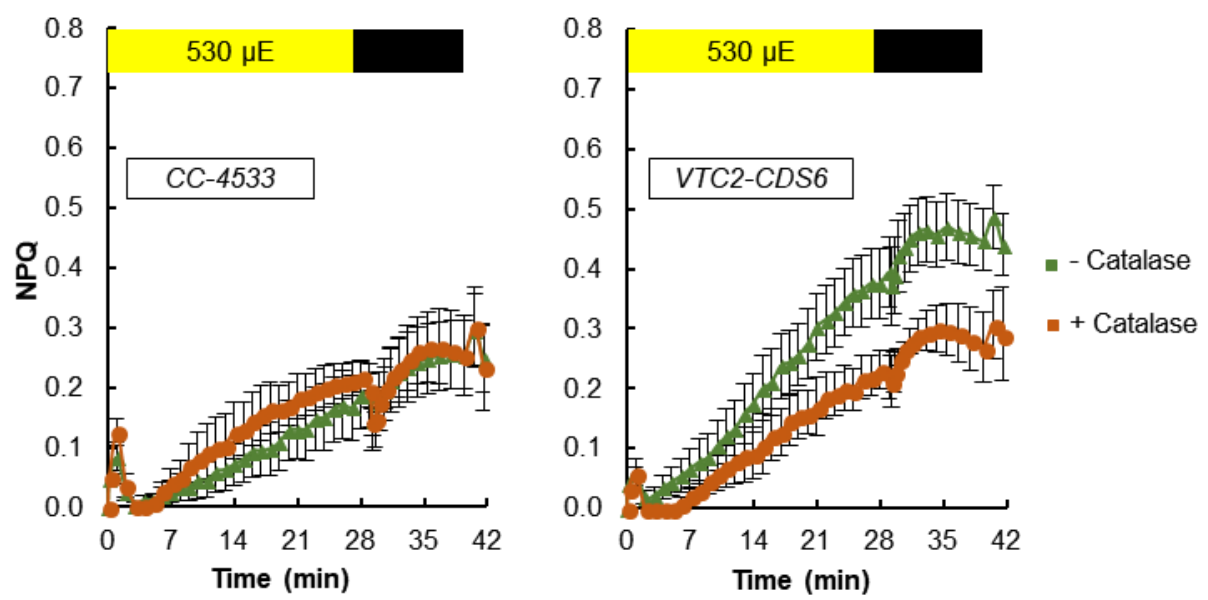

Figure 43. NPQ induction of C. reinhardtii CC-4533 and VTC2-CDS6 strains grown in TAP medium at $100 \mu$ mole photons $\mathrm{m}^{-2} \mathrm{~s}^{-1}$ with and without the addition of (a) $\mathrm{H}_{2} \mathrm{O}_{2}$ or (b) catalase. $\mu \mathrm{E}$ stands for $\mu$ mole photons $\mathrm{m}^{-2} \mathrm{~s}^{-1}$.

\subsection{3) The effects of Asc deficiency on NPQ in cultures grown under} photoautotrophic conditions at normal light

NPQ processes are often studied under photoautotrophic conditions, in HSM medium. The rapidly inducible component of NPQ (most probably qE) became significant when the cultures were grown photoautotrophically under normal light intensity (Figure 44). This phase was followed by a slower one, which is likely being $\mathrm{qZ}$, since during this phase de-epoxidation increased and the ratio $684 \mathrm{~nm} / 710 \mathrm{~nm}$ of the $77 \mathrm{~K}$ spectra increased only in the WT strain (Figure $45 \mathrm{~A}, \mathrm{~B}$ ), and the carotenoid contents did not change (Figure 46). Furthermore, the NPQ kinetics in the stt7 mutant are very similar, suggesting also the absence of $\mathrm{qT}$ induction under these 
conditions (Figure 47). In the VTC2 mutant, the $\mathrm{qE}$ and the $\mathrm{qZ}$ components were essentially the same as in the parent strain.

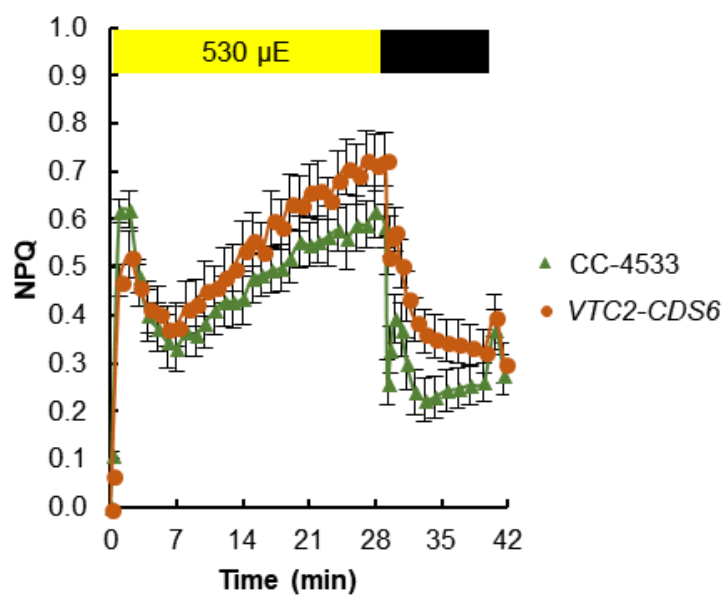

Figure 44. NPQ induction in $C$. reinhardtii $\mathrm{CC}-4533$ and VTC2-CDS6 strains grown in HSM medium at $100 \mu$ mole photons $\mathbf{m}^{-2} \mathbf{s}^{-1} \cdot \mu \mathrm{E}$ stands for $\mu$ mole photons $\mathrm{m}^{-2} \mathrm{~s}^{-1}$.

(a)

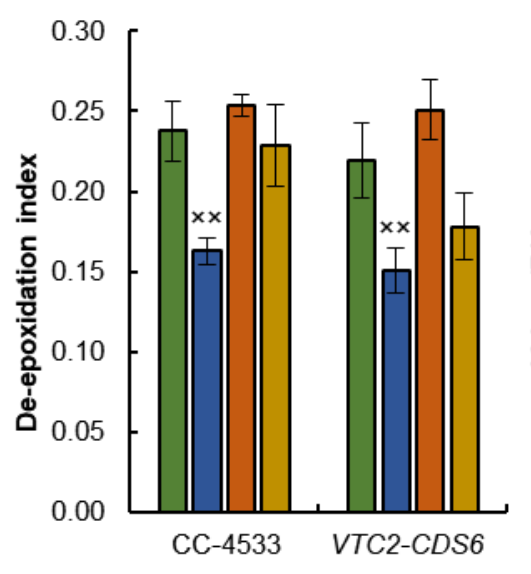

(b)

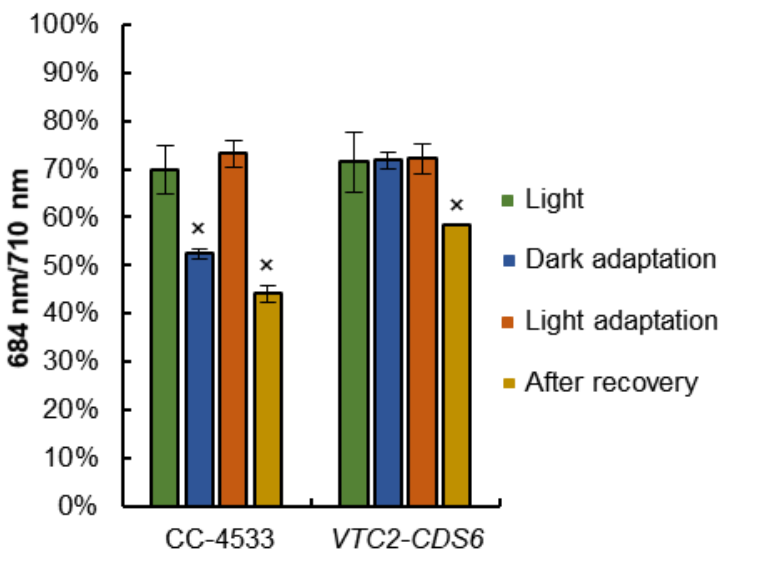

Figure 45. (a) De-epoxidation index and (b) $684 \mathrm{~nm} / 710 \mathrm{~nm}$ ratio of the $77 \mathrm{~K}$ fluorescence spectra of $C$. reinhardtii CC-4533 and VTC2-CDS6 strains grown in HSM medium at $100 \mu$ mole photons $\mathrm{m}^{-2} \mathrm{~s}^{-1}$. The samples were collected at several time-points during the NPQ induction protocol. Statistical significance levels are presented relative to the light adapted $\mathrm{CC}-4533$ strain as: $\times \mathrm{p}<0.05 ; \times \times$ $\mathrm{p}<0.01$. 


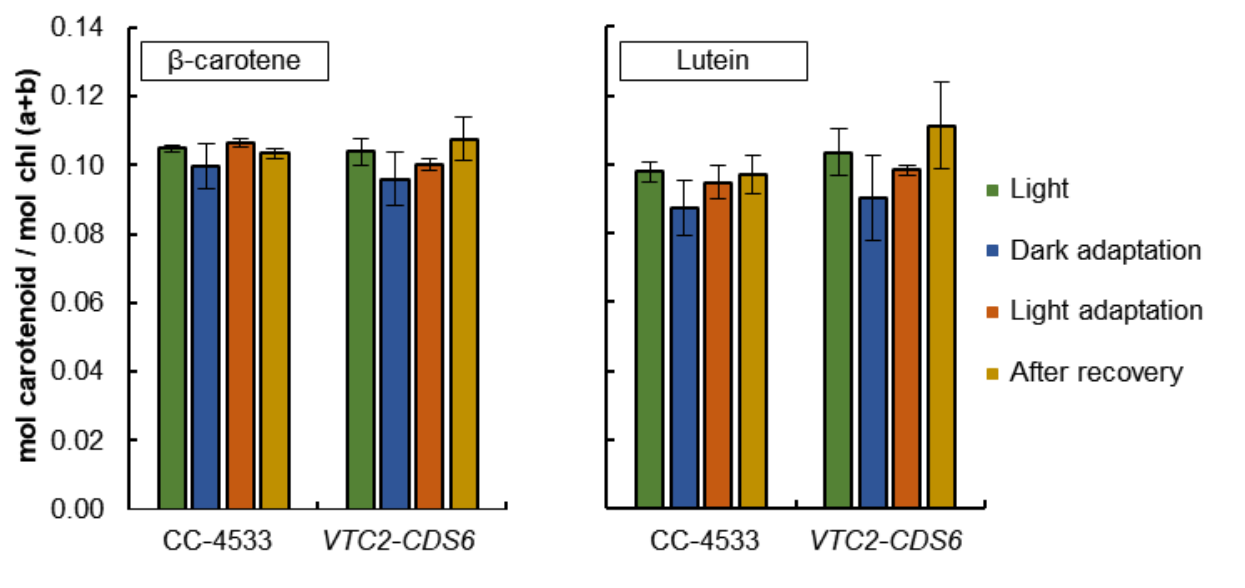

Figure 46. Carotenoid content levels (normalized to $\mathrm{Chl}$ ) of $C$. reinhardtii CC-4533 and VTC2-CDS6 strains grown in HSM medium at 100 $\mu$ mole photons $\mathbf{~ m}^{-2} \mathbf{s}^{-1}$. The samples were collected at several time-points during the NPQ induction protocol.

Treatments with $1.5 \mathrm{mM} \mathrm{H}_{2} \mathrm{O}_{2}$ led to a slight acceleration in NPQ kinetics in both strains (Figure 48 A) and catalase treatment resulted in no visible changes when compared to the non-treated cultures (Figure $48 \mathrm{~B}$ ), suggesting that the cellular machinery might capable of efficiently detoxifying ROS under photoautotrophic growth under normal light intensities.

The $N P Q 1$ mutant, lacking CrVDE was moderately affected in the rapid $\mathrm{qE}$ component, whereas the second, slower phase that we attributed to $\mathrm{qZ}$ was absent. The NPQ4 mutant, lacking LHCSR3 was more strongly affected in $\mathrm{qE}$, whereas its qZ phase was unaltered relative to its WT, strain 137AH (Figure 49). De-epoxidation correlated with the occurrence of $\mathrm{qZ}$ and the $684 \mathrm{~nm} / 710 \mathrm{~nm}$ ratio of the $77 \mathrm{~K}$ spectra was essentially unaltered (Figure 50), showing unambiguously that the slow phase is due to $\mathrm{qZ}$. 


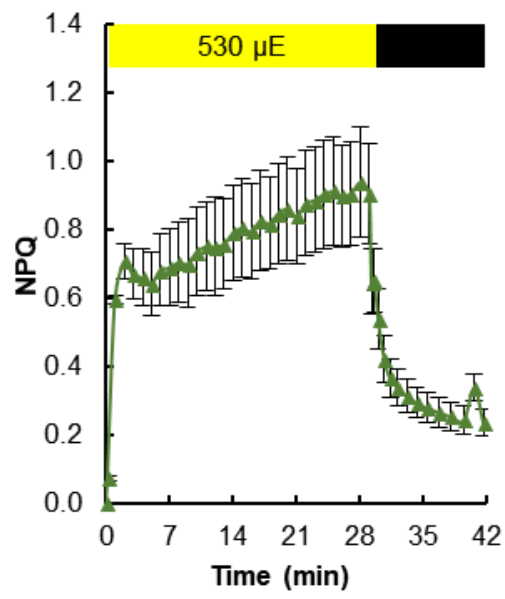

Figure 47. NPQ induction in $C$. reinhardtii stt7 mutant grown in HSM medium at $100 \mu$ mole photons $\mathbf{m}^{-2} \mathrm{~s}^{-1}$. $\mu \mathrm{E}$ stands for $\mu$ mole photons $\mathrm{m}^{-2} \mathrm{~s}^{-1}$.

(a)
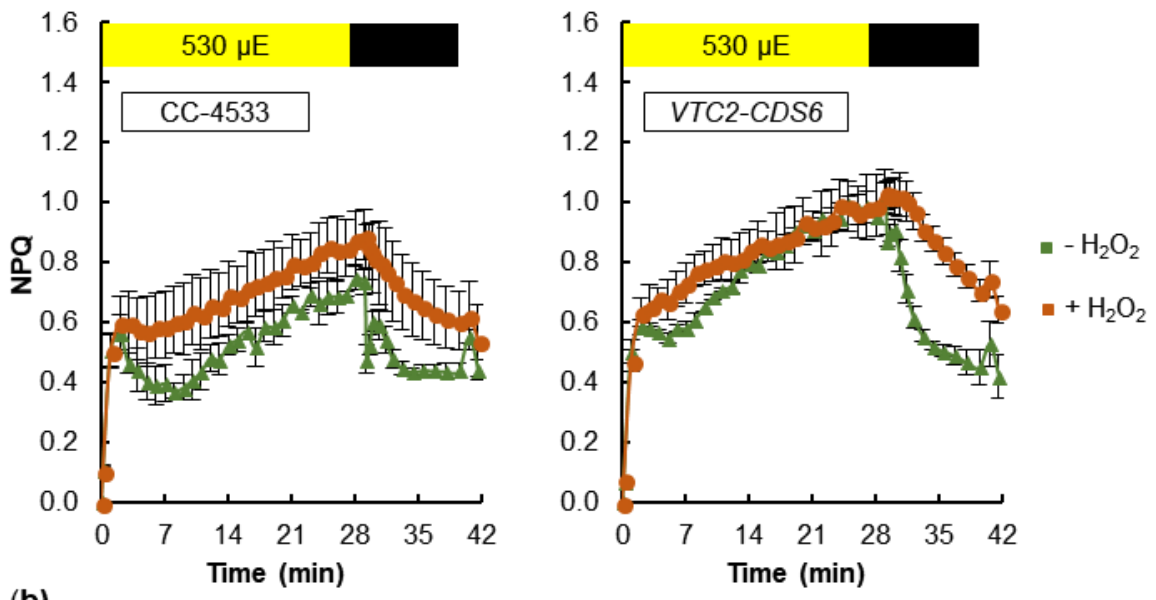

(b)
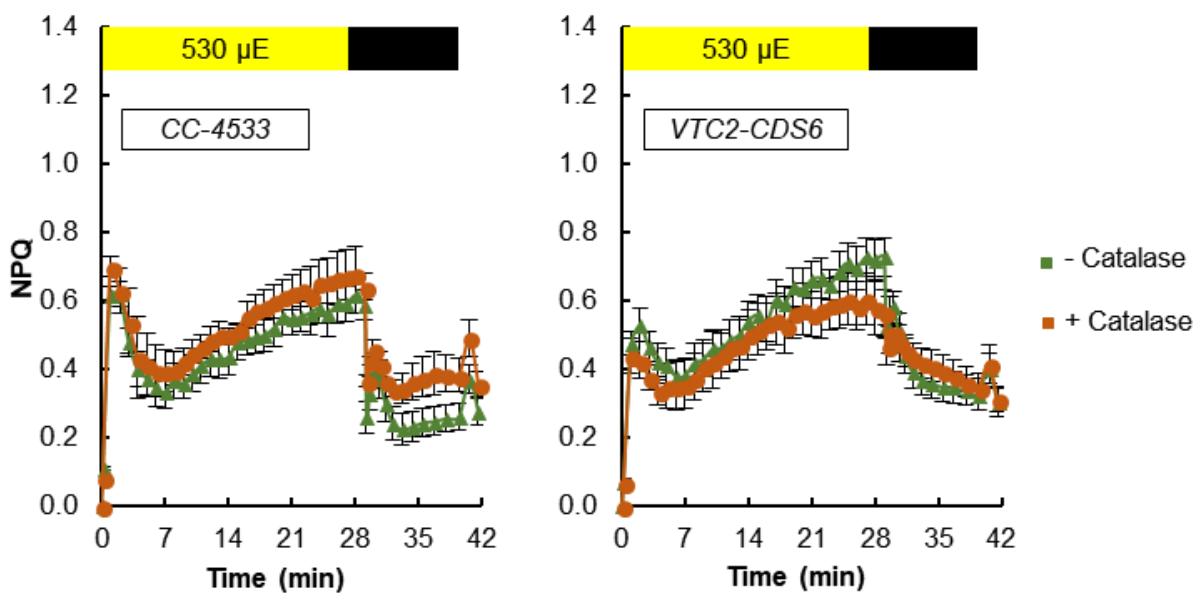

Figure 48. NPQ induction of $C$. reinhardtii CC-4533 and VTC2-CDS6 strains grown in HSM medium at $100 \mu$ mole photons $\mathrm{m}^{-2} \mathrm{~s}^{-1}$ with and without the addition of (a) $\mathrm{H}_{2} \mathrm{O}_{2}$ or (b) catalase. $\mu \mathrm{E}$ stands for $\mu$ mole photons $\mathrm{m}^{-2} \mathrm{~s}^{-1}$. 


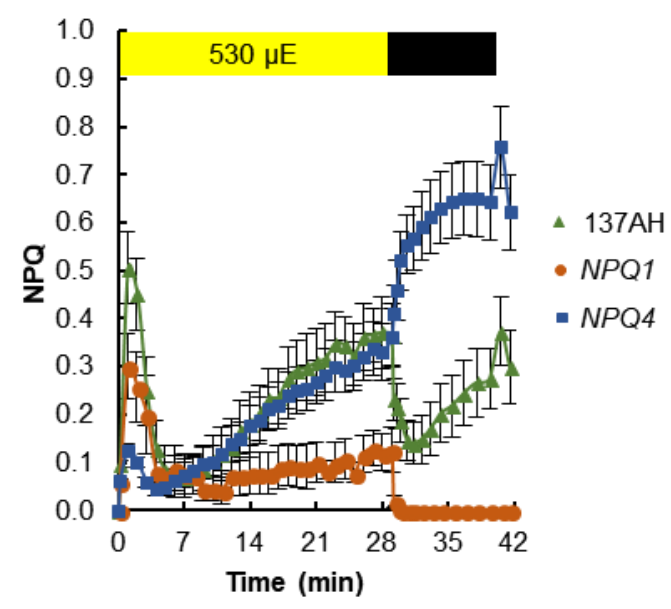

Figure 49. NPQ induction in $C$. reinhardtii 137AH, NPQ1 and NPQ4 strains grown in HSM medium at $100 \mu$ mole photons $\mathbf{m}^{-2} \mathbf{s}^{-1} \cdot \mu \mathrm{E}$ stands for $\mu$ mole photons $\mathrm{m}^{-2} \mathrm{~s}^{-1}$.

(a)

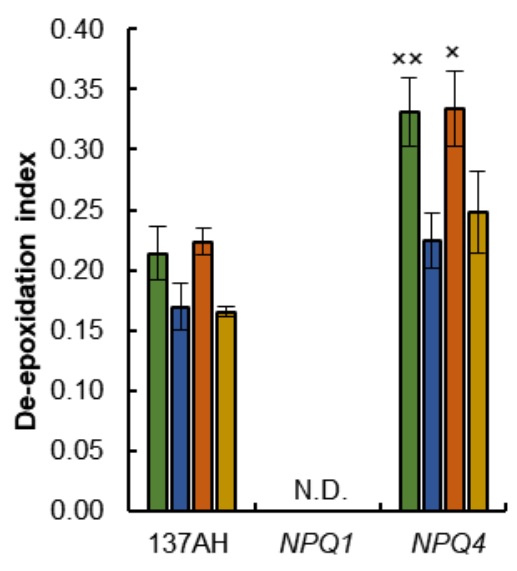

(b)

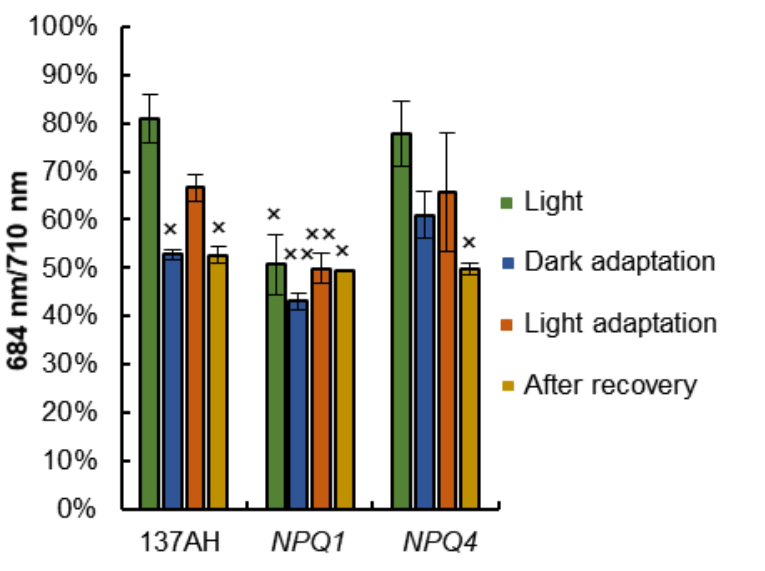

Figure 50. (a) De-epoxidation index and (b) $684 \mathrm{~nm} / 710 \mathrm{~nm}$ ratio of the $77 \mathrm{~K}$ fluorescence spectra of $C$. reinhardtii $137 \mathrm{AH}, N P Q 1$ and $N P Q 4$ strains grown in HSM medium at $100 \mu$ mole photons $\mathbf{m}^{-2} \mathrm{~s}^{-1}$. The samples were collected at several time-points during the NPQ induction protocol. Statistical significance levels are presented relative to the light adapted 137AH strain as:

$\times \mathrm{p}<0.05 ; \times \times \mathrm{p}<0.01$. N.D. stands for Not Detectable.

Interestingly, the Asc content of the CC-4533 strain was much lower in photoautotrophic conditions than in TAP medium (approx. 2.3 vs. $10 \mathrm{pmol} \mathrm{Asc} / \mu \mathrm{g}$ Chl $(a+b))$, whereas in the Asc-deficient mutant it stayed at a constantly low level, about 1.5 pmol Asc/ $\mu \mathrm{g} \mathrm{Chl(a+b)} \mathrm{(Figure} \mathrm{51).}$ 


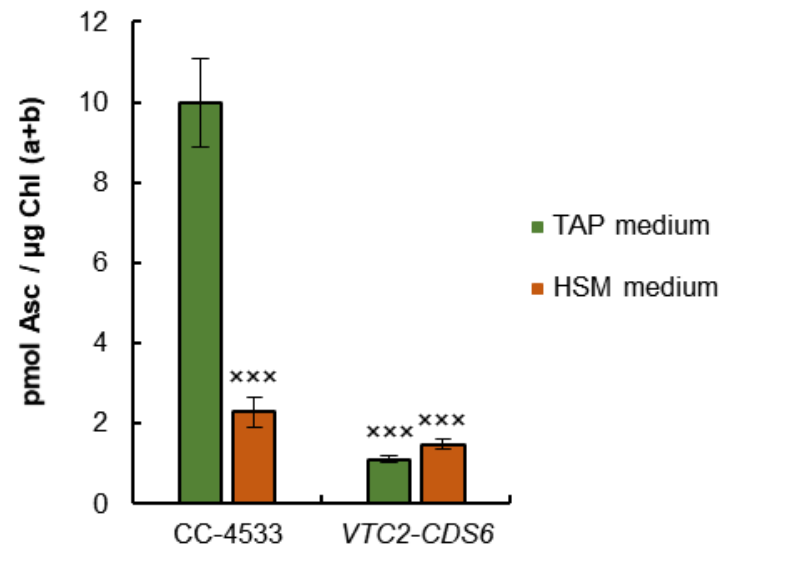

Figure 51. Asc content (expressed on a Chl basis) in $C$. reinhardtii CC-4533 and VTC2-CDS6 strains grown in either TAP or HSM medium at 100 $\mu$ mole photons $\mathbf{~ m}^{-2} \mathbf{s}^{-1}$. Statistical significance levels are presented relative to the TAP-grown CC-4533 strain as: $x \times \times p<0.001$.

\subsection{4) The effects of Asc deficiency on NPQ in cultures grown under} photoautotrophic conditions at high light

When the cultures were grown under photoautotrophic conditions at high light $\left(530 \mu\right.$ mole photons $\left.\mathrm{m}^{-2} \mathrm{~s}^{-1}\right), \mathrm{qE}$ reached high values (Figure $52 \mathrm{~A}$ ). This phase was followed by a slower one, which was more prominent in the Asc-deficient mutant. This slow component could also be observed in our VTC2-amiRNA line as well (Figure 52 B), but in that background qE was induced only upon Asc-deficiency and not in the control strain. During this phase, the de-epoxidation index was not changed, the ratio $684 \mathrm{~nm} / 710 \mathrm{~nm}$ of the $77 \mathrm{~K}$ spectra remained constant in the Ascdeficient mutant (Figure 53), and the carotenoid contents did not decrease (Figure 54); however, it is important to note that the total amount of $\beta$-carotene was constantly and significantly down-regulated in the Asc-deficient mutant, suggesting that photoinhibition may take place in this strain under high light conditions. In the stt7 mutant, the slow component was also absent under these conditions (Figure 55). Since qZ and qT can be excluded, we speculate that Asc-deficiency might have led to some form of qI. 
(a)

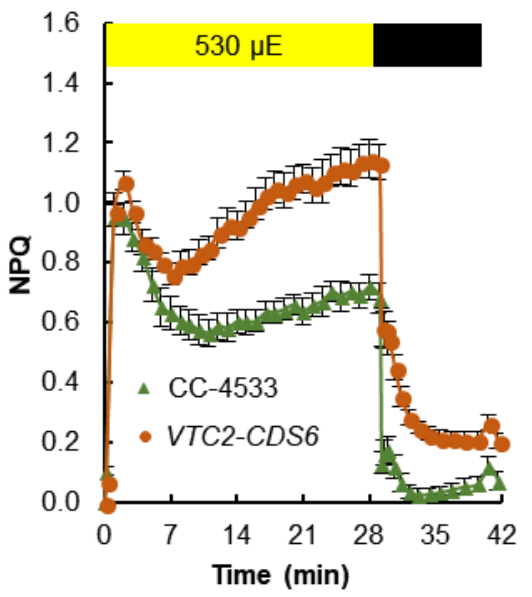

(b)

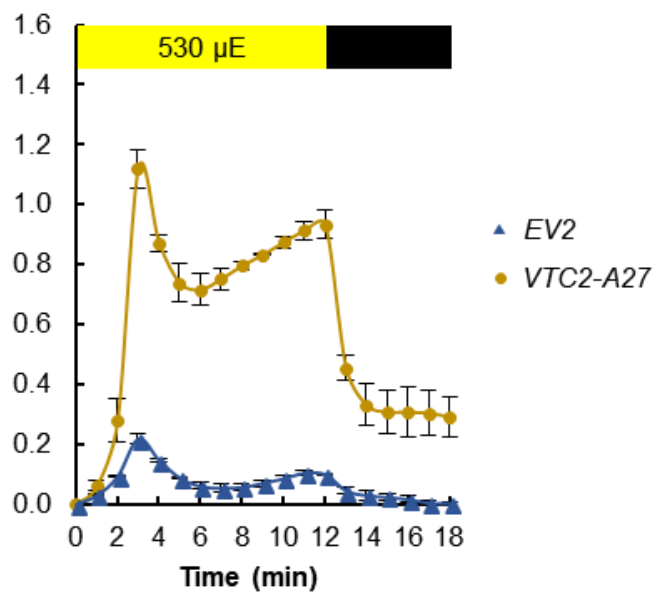

Figure 52. NPQ induction in C. reinhardtii grown in HSM medium at 530 $\mu$ mole photons $\mathbf{~ m}^{-2} \mathbf{s}^{-1}$. (a) CC-4533 and VTC2-CDS6 strains obtained from the CLiP library; (b) EV2 and VTC2-A27 strains used in our previous studies (VidalMeireles et al., 2017). $\mu \mathrm{E}$ stands for $\mu$ mole photons $\mathrm{m}^{-2} \mathrm{~s}^{-1}$.

(a)

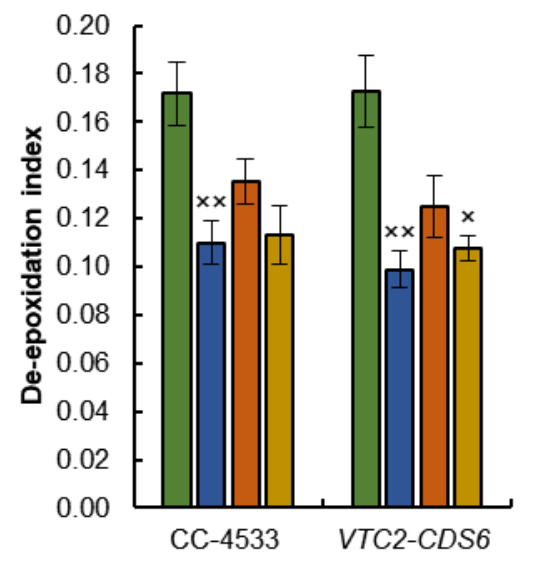

(b)

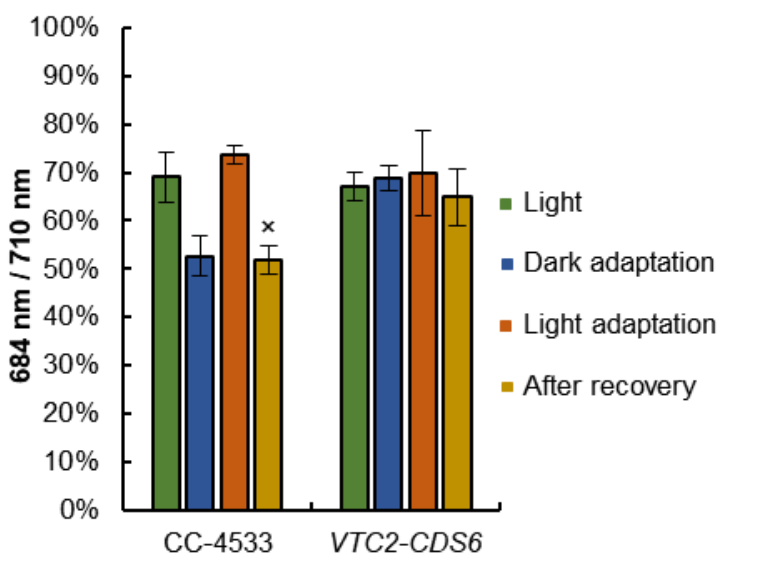

Figure 53. a) De-epoxidation index and (b) $684 \mathrm{~nm} / 710 \mathrm{~nm}$ ratio of the 77 $\mathrm{K}$ fluorescence spectra of $C$. reinhardtii $\mathrm{CC}-4533$ and VTC2-CDS6 strains grown in HSM medium at $530 \mu$ mole photons $\mathbf{m}^{-2} \mathbf{s}^{-1}$. The samples were collected at several time-points during the NPQ induction protocol. Statistical significance levels are presented relative to the light adapted CC -4533 strain as: $\times p<0.05 ; \times \times p<0.01$. 

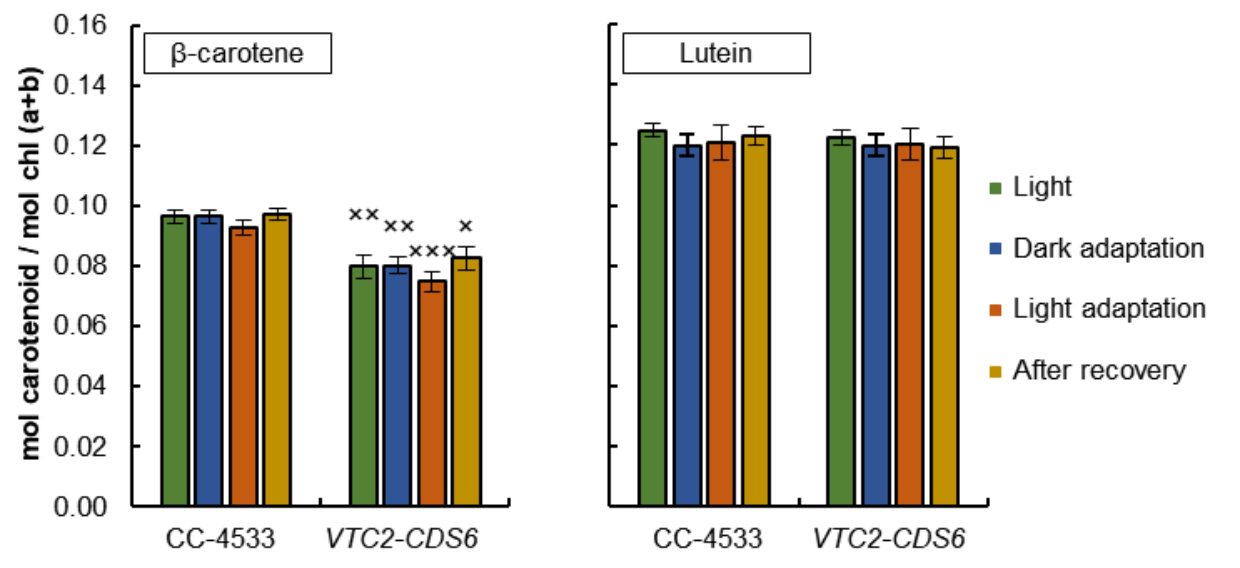

Figure 54. Carotenoid content levels (normalized to $\mathrm{Chl}$ ) of $C$. reinhardtii CC-4533 and VTC2-CDS6 strains grown in HSM medium at $530 \mu$ mole photons $\mathbf{m}^{-2} \mathbf{s}^{-1}$. The samples were collected at several time-points during the NPQ induction protocol. Statistical significance levels are presented relative to the light adapted $\mathrm{CC}-4533$ strain as:

$\times \mathrm{p}<0.05 ; \times \times \mathrm{p}<0.01 ; \times \times \times \mathrm{p}<0.001$.

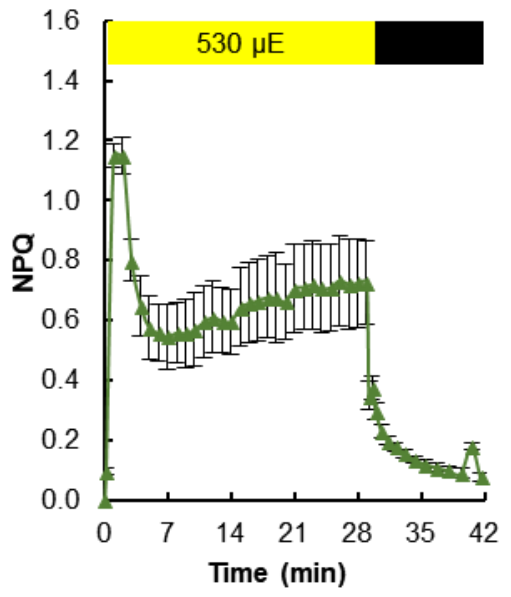

Figure 55. NPQ induction in $C$. reinhardtii stt7 mutant grown in HSM medium at $530 \mu$ mole photons $\mathbf{m}^{-2} \mathrm{~s}^{-1}$. $\mu \mathrm{E}$ stands for $\mu$ mole photons $\mathrm{m}^{-2} \mathrm{~s}^{-1}$.

Treatments with $1.5 \mathrm{mM} \mathrm{H}_{2} \mathrm{O}_{2}$ led to sustained NPQ induction in both strains (Figure $56 \mathrm{~A}$ ), and catalase treatment resulted in a strong decrease of NPQ in the Asc-deficient mutant (Figure $56 \mathrm{~B}$ ), confirming that under these conditions Ascdeficiency is associated with strong oxidative stress and qI induction. 
(a)
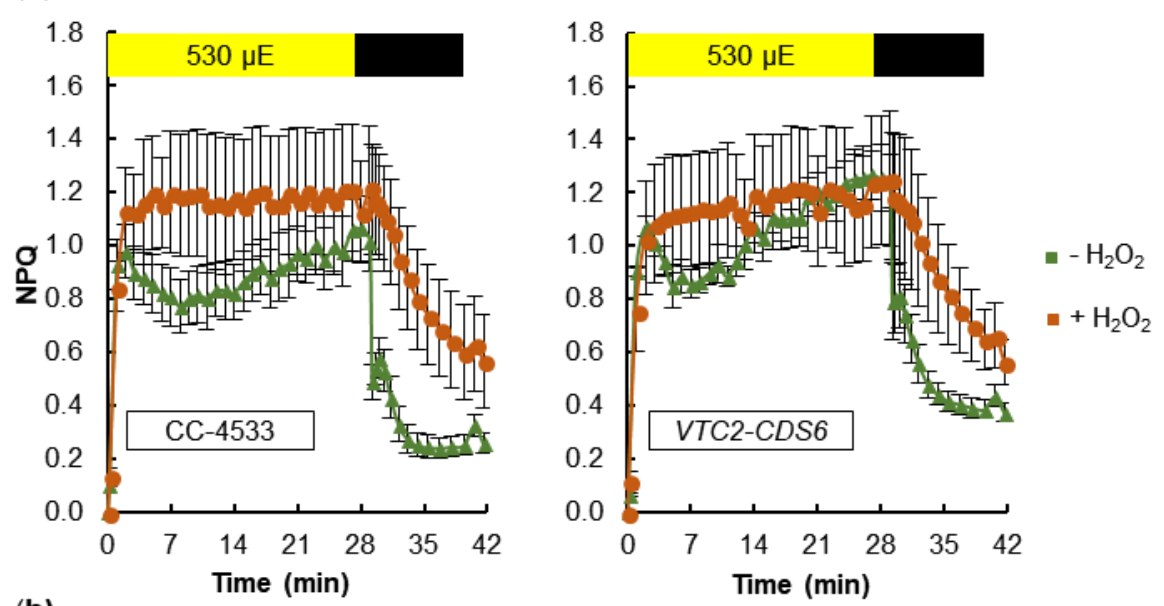

(b)
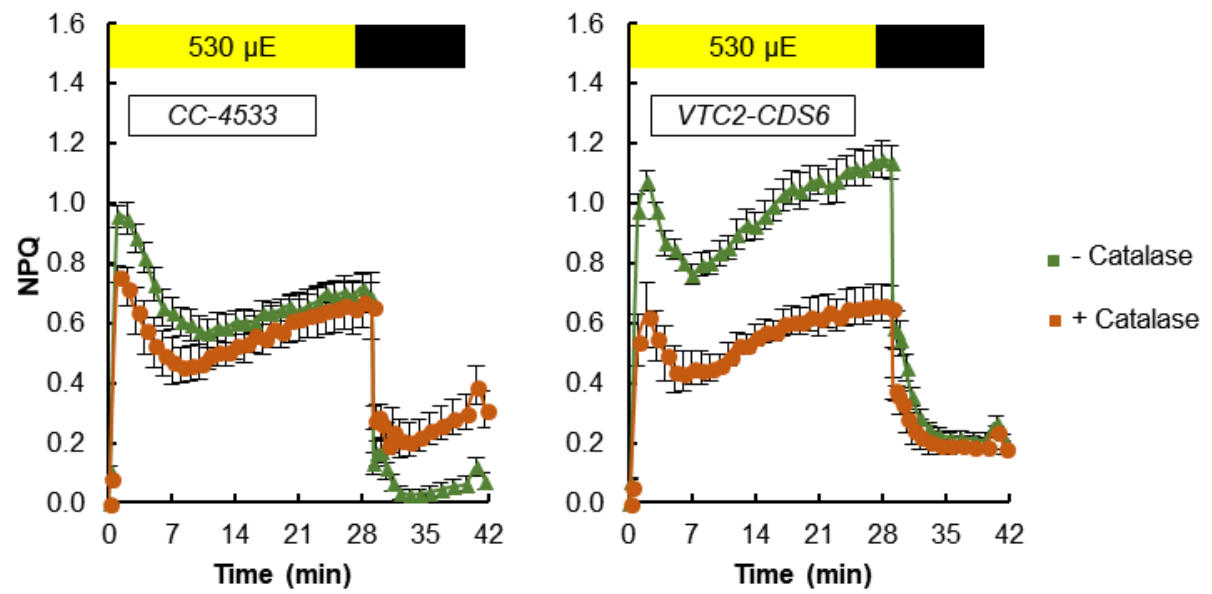

Figure 56. NPQ induction of $C$. reinhardtii CC-4533 and VTC2-CDS6 strains grown in HSM medium at 530 mole photons $\mathrm{m}^{-2} \mathrm{~s}^{-1}$ with and without the addition of (a) $\mathrm{H}_{2} \mathrm{O}_{2}$ or (b) catalase. $\mu \mathrm{E}$ stands for $\mu$ mole photons $\mathrm{m}^{-2} \mathrm{~s}^{-1}$.

Our results demonstrate that, as opposed to seed plants, in the green algae $C$. reinhardtii Asc is not required as a co-factor for VDE. Under photomixotrophic growth at normal light intensities, qZ was the main NPQ component, and $\mathrm{H}_{2} \mathrm{O}_{2}$ enhanced the slow NPQ component induction; the experiments on the NPQ1 mutant show the importance of CrVDE activity under these growth conditions.

When the cultures are grown under photoautotrophic growth at normal light intensities, $\mathrm{qE}$ becomes visible and $\mathrm{qZ}$ is still induced. Under these conditions $\mathrm{H}_{2} \mathrm{O}_{2}$ is either efficiently detoxified by the cells or has no effect on the slow NPQ component.

If the cultures are grown at high light and photoautotrophic conditions, $\mathrm{qE}$ induction is maximal and $\mathrm{qZ}$ is no longer induced during the NPQ measurements. Under these conditions, lack of Asc causes qI induction (seen as a slow NPQ 
component) which might be triggered by $\mathrm{H}_{2} \mathrm{O}_{2}$, since the catalase treatment decreased this effect. 



\section{5.) DISCUSSION}

\section{1) Regulation of the Asc biosynthesis and its physiological importance}

\section{in C. reinhardtii}

We aimed at gaining insights into the regulation of Asc biosynthesis by studying the consequences of Asc deficiency in C. reinhardtii. As a target gene, we selected VTC2, encoding GDP-L-galactose phosphorylase, because it is highly regulated both in higher plants and in C. reinhardtii (Blaby et al., 2015; Dowdle et al., 2007; Urzica et al., 2012). We opted for the amiRNA approach, because it is highly efficient and, with this technique, possible side effects due to off-targeting are minimized (Molnar et al., 2009; Schmollinger et al., 2010). The transformants are also more stable relative to antisense and inverted repeat constructs, although we have observed that one of our transformants, VTC2-B75, became silenced during the course of the experiments.

The miRNAs can act either via transcriptional or post-transcriptional regulation of the target sequence. The post-transcriptional mechanisms may involve translational arrest or targeted RNA degradation. Initially, it was suggested that translational arrest occurs mostly in animals, however, increasing evidence indicates that, in addition to transcript degradation (Tiwari et al., 2014), translational inhibition may also occur in plants (Iwakawa and Tomari, 2013; Li et al., 2013; Ma et al., 2013).

In our experiments with amiRNA constructs, both algal transformation and the downregulation of Asc biosynthesis were highly efficient. In our selected VTC2-amiRNA lines (VTC2-A27 and VTC2-B75), the Asc content was reduced to about $10 \%$ of the control strains under standard growth conditions (Figure 8). However, we detected an only approximately $60 \%$ decrease at the transcript level (Figure 10). Upon $\mathrm{H}_{2} \mathrm{O}_{2}$ treatment, the expression level of VTC2 increased strongly in the VTC2-amiRNA lines, even more so than in the $\mathrm{H}_{2} \mathrm{O}_{2}$-treated EV2 samples (Figure 10), most probably because in the VTC2-amiRNA lines $\mathrm{H}_{2} \mathrm{O}_{2}$ could not be scavenged efficiently, leading to a further increase in VTC2 transcript levels. On the other hand, the amount of Asc increased only moderately in the VTC2-amiRNA lines (Figure 8). Similar effects were observed upon dark-light transition (Figure 23), indicating that the VTC2-amiRNA acted largely via a translational arrest mechanism. 


\subsection{1) Physiological consequences of Asc deficiency in $C$. reinhardtii}

Under normal growth conditions, the cellular Asc concentration in Arabidopsis is about 5 to $6 \mathrm{mM}$ (Conklin et al., 2000; Zechmann et al., 2011). The Asc-deficient vtc2-1 Arabidopsis mutant, possessing about $2 \mathrm{mM}$ cellular Asc, is phenotypically inconspicuous, has an unaltered chl content and performs efficient photosynthesis under standard growth conditions (Müller-Moulé et al., 2004; Tóth et al., 2009). It had been reported that Asc deficiency leads to decreased growth; however, it was demonstrated recently that the observed growth retardation was largely due to an independent cryptic mutation present in the original vtc2-1 mutant (Lim et al., 2016).

Our VTC2-amiRNA lines containing about $50 \mu \mathrm{M}$ Asc (i.e., about $10 \%$ of that of the control EV2 strain), are characterized by a slower growth (Figure 13), and a strong, about 60\% decrease in Chl content (Figure 14). However, the effect of Ascdeficiency on the $\mathrm{Chl}$ content was not observed in the experiments using the insertional mutant VTC2-CDS6 (Figure $35 \mathrm{~A}$ ); since the strains with the cw15-325 background are cell-wall deficient, whereas the CC-4533 are cell-wall containing, it is possible that the effect observed with the VTC2-amiRNA is an indirect effect due to the constitutive stress these lines suffer. We additionally demonstrated that Asc deficiency leads to decreased photosynthetic electron transport rates particularly at high light intensities (Figure 18), most probably due to increased cellular $\mathrm{H}_{2} \mathrm{O}_{2}$ accumulation (Figure 19). Various changes were observed also in the metabolite profiles (Figure 17), including increased proline content, a stress indicator in $C$. reinhardtii (Mastrobuoni et al., 2012), and decreased glycerol-3-phosphate content. Together, these results indicate that our VTC2-amiRNA lines are under chronic oxidative stress. It thus seems conceivable that their severe Asc deficiency may also affect cellular functions that are not directly related to the antioxidant role of Asc; these effects may change however depending on the background of the strains selected for the studies.

\subsection{2) Regulation of Asc biosynthesis in C. reinhardtii vs. higher plants}

In non-vascular plants, including bryophytes and green algae, the Asc concentration may be about 100-fold lower than in higher plants, and cyanobacteria contain even less, or possibly no Asc at all (Gest et al., 2013; Wheeler et al., 2015). During evolution, the transition to life on land has increased the exposure of plants to 
environmental stresses and Asc, as a major cellular antioxidant, became instrumental in protection against ROS (Foyer and Noctor, 2011). As a consequence, Asc became one of the most abundant metabolites in land plants, which is relatively costly from an energetic point of view. Upon prolonged stress exposure of higher plants, a rather slow, about two- or three-fold additional increase can occur on the timescale of days (Müller-Moulé et al., 2004).

C. reinhardtii lives both in freshwater and soil, and may encounter high light and other environmental stress factors, although probably less frequently than land plants. Since algae contain much less Asc than higher plants, we raised the question how they are capable of coping with oxidative stress.

One of the most notable features of Asc metabolism in C. reinhardtii is the speed and the scale of the increase in Asc content. We observed a three-fold increase upon $\mathrm{H}_{2} \mathrm{O}_{2}$ treatment within $7 \mathrm{~h}$ (Figure 9), which is in agreement with previous results (Urzica et al., 2012). There was a similar, five-fold increase upon $4 \mathrm{~h}$ of RB treatment (Figure 20). We also observed a significant, about two-fold increase upon high-light treatment (igure 9), and a dramatic, circa 50-fold increase in Asc content was observed earlier upon two days of sulphur deprivation (Nagy et al., 2016). As shown by real-time qPCR, these changes were related to the increased transcript abundance of the VTC2 gene.

We also demonstrate that both $\mathrm{H}_{2} \mathrm{O}_{2}$ and ${ }^{1} \mathrm{O}_{2}$ increase the expression of VTC2, probably by acting as signaling molecules. In plants, the signaling pathways of $\mathrm{H}_{2} \mathrm{O}_{2}$ and ${ }^{1} \mathrm{O}_{2}$ are very complex and appear to be integrated with many different signaling networks, including protein kinase networks, calcium signaling, metabolic networks and redox responses (Mittler et al., 2011). In addition, ROS may act as chloroplastic retrograde signals and play an important role in environmental acclimation (Chi et al., 2015; Suzuki et al., 2012). Investigating the effects of ROS signaling on VTC2 expression will be an interesting topic of future studies.

In higher plants, it has been shown that the transcript level of VTC2 depends on photosynthetic electron transport, particularly during high-light acclimation (Dowdle et al., 2007). However, the exact mechanism is not known, and to our knowledge, the possible role of ROS has not been investigated. Here we show that, in C. reinhardtii, photosynthetic electron transport is not required per se for Asc accumulation, since Asc biosynthesis could be induced in the dark by $\mathrm{H}_{2} \mathrm{O}_{2}$ treatment (Figure 22). Also, in DCMU-treated cells, the Asc content rather increased than 
decreased (Figure 20). Using the pgrll mutant, we additionally established that PSI cyclic electron flow does not influence Asc accumulation (Figure 21). Instead, we propose that ROS produced in the chloroplast, for example, upon exposure to high light, is the primary signal for changes in VTC2 expression.

The Asc content of higher plants is subject to strong daily changes, due to the circadian rhythm of VTC2 transcript accumulation (Dowdle et al., 2007). Our data show that this is not the case in $C$. reinhardtii. When the cultures are grown under light-dark cycles, several fold changes occur in the Asc content (Figure 24) and rather high levels (about $1000 \mu \mathrm{M}$ ) are reached within $3 \mathrm{~h}$ of illumination with normal growth light. However, when these cultures are subsequently grown under constant light, the Asc level remains low (less than $200 \mu \mathrm{M}$ ), without any changes during the day. It is, however, noteworthy that an increase in $\mathrm{H}_{2} \mathrm{O}_{2}$ concentration was observed upon dark-light transition (Figure 23), which may account for the increased VTC2 transcript level.

Ascorbate is generally thought to be a non-toxic molecule, although in the presence of metal ions, it may act as a pro-oxidant (Dumville and Fry, 2003). It has also been observed that, under certain conditions, Asc can inactivate the oxygenevolving complex of PSII due to its reducing capacity (Nagy et al., 2016; Tamura et al., 1990). Most probably in order to minimize these effects, a negative feedback regulation of the VTC2 transcript level has evolved in higher plants (Dowdle et al., 2007). It was recently shown that feedback is also exerted through a phylogenetically conserved cis-acting upstream open reading frame (uORF) encoding a 60 to 65 amino acid peptide in the 5'UTR of the VTC2 gene. This feedback loop acts posttranscriptionally, presumably by influencing the translation rate of the GDP-Lgalactose phosphorylase enzyme (Bulley and Laing, 2016; Laing et al., 2015). However, the non-canonical start codon of this uORF (ACG) is absent from $C$. reinhardtii (Laing et al., 2015) and, instead, there is a CUG codon in this position. In a sequence context-dependent manner, CUG can function as a translational start codon in plants (Christensen, 2005; Kobayashi et al., 2002) - whether or not it is used for uORF translation from the 5'UTR of the VTC2 gene in Chlamydomonas remains to be determined.

We have found that Asc has no negative feedback effect on the VTC2 transcript. Instead, VTC2 mRNA abundance increased upon a $2 \mathrm{mM}$ Asc supplementation in both the EV2 and the VTC2-A27 strains (Figure 26). The 
increased VTC2 expression level may have contributed to the increased cellular Asc content (Figure $25 \mathrm{~A}$ ), although it is possible that Asc was also taken up from the liquid medium via yet unidentified Asc transporters (Fernie and Tóth, 2015). A feedforward regulation by Asc on the VTC2 transcript would be rather unusual, because metabolic pathways are most often negatively feedback-regulated by their endproducts (Farré et al., 2014). However, some plant hormones, such as abscisic acid can show positive feedback regulation by activating some of its biosynthetic genes (Guan et al., 2015; Xiong, 2003; Yang and Tan, 2014). We, therefore, hypothesize that a feed-forward loop in Asc biosynthesis enhances stress adaptation responses in Chlamydomonas. As the maximum Asc content that we observed was approximately $1.3 \mathrm{mM}$ in this study and $3 \mathrm{mM}$ under sulfur deprivation (Nagy et al., 2016, see chapter 4.2.2), there is likely a mechanism involved that limits the feed-forward regulation in a stress-specific manner and prevents it from overshooting. 
5.2) Determination of the role of Asc in the inactivation of PSII during sulphur deprivation-induced $\mathrm{H}_{2}$ production in $C$. reinhardtii

It has been assumed for many years that PsbA turnover is limited upon sulphur starvation, and that it is the simple reason for a decline in PSII activity (Antal et al., 2015; Volgusheva et al., 2013; Wykoff et al., 1998); however, several lines of evidence found in the literature, and presented in this thesis, show that the decrease in PSII activity is caused by a more complex phenomenon.

When transferring the cells to sulphur-free media, the transcript abundances of a large number of nuclear-encoded photosynthetic complexes decrease within a few hours, including those of the majority of PSI and PSII light-harvesting complexes, subunits of Rubisco, cytb ${ }_{6}$ f complex and PSII subunits, including the extrinsic OEC proteins (Nguyen et al., 2011; Toepel et al., 2013). Concomitantly, the transcript abundances of special LHCs, namely LHCSR and LHCBM9, are strongly increased, resulting in the remodeling of light-harvesting super-complexes (Grewe et al., 2014). Thereupon transferring cells to sulphur-free media, cell division and Chl biosynthesis also cease, and the cell size is doubled, with a concomitant accumulation of starch, which is enabled by the initially active CBB cycle.

\subsection{1) The degradation of photosynthetic complexes during sulphur} deprivation

It is very likely that the quantity of sulphur per photosynthetic reaction center decreases only moderately upon transferring the cells to sulphur-free media, and this may not substantially hinder the turnover of PsbA. Our results presented in Figure 27 show that PsbA has a remarkable turnover, and its level decreases more slowly than that of $\mathrm{RbcL}$ and $\mathrm{CP} 43$, which are both known to possess a lower turnover rate than PsbA under normal conditions (Nelson et al., 2014). In addition, the LM treatments also show that the rate of PsbA degradation is increased upon sulphur deprivation (Figure 27), whereas its re-synthesis is not necessarily affected.

The loss of PsbA, therefore, seems to be a complex phenomenon. As mentioned above, gene expression patterns are changed within hours upon transferring Chlamydomonas cells to sulphur-free medium, well before the actual damaging effects of sulphur limitation occur. One of the most remarkable effects is the loss of CBB cycle activity, which seem to be a regulated process, because in addition to the remarkable decrease in the expression of the small Rubisco subunits 
(Toepel et al., 2013), a very rapid loss of RbcL occurs (Figure 27), which, under normal conditions, has a slow turnover (Nelson et al., 2014). During this initial stage of sulphur deprivation (approximately the first $24 \mathrm{~h}$ ), there is some CBB cycle activity, which enables starch accumulation; however, the decrease of the CBB cycle activity leads to a slowdown of linear electron transport and overexcitation of PSII (Melis et al., 2000). We observed a decrease in cellular $\mathrm{H}_{2} \mathrm{O}_{2}$ content instead of an increase, but our gene expression data show that ${ }^{1} \mathrm{O}_{2}$ is very likely to accumulate (Figure 29), which may damage the photosynthetic apparatus.

\subsection{2) GDP-L-galactose phosphorylase is induced upon sulphur} deprivation

The transcript abundance of the VTC2 gene, which plays an important regulatory role in Asc biosynthesis in C. reinhardtii (Urzica et al., 2012; VidalMeireles et al., 2017, see chapter 4.1), is also increased (Figure 28 A), probably in response to ${ }^{1} \mathrm{O}_{2}$ production, and Asc accumulates to the $\mathrm{mM}$ range (Figure $28 \mathrm{~B}$ ). Ascorbate is generally regarded as an ROS scavenger (Foyer and Shigeoka, 2011), and it may also play this role upon sulphur deprivation; however, our data presented in this and in our previous paper (Nagy et al., 2016) show that when present in the $\mathrm{mM}$ range, Asc may contribute to the inactivation of PSII by over-reducing the $\mathrm{Mn}$ cluster in $C$. reinhardtii.

When considering the physiological roles of Asc, it has to be taken into account that it is a reductant, and therefore its cellular concentration is to be maintained in a certain range and there are substantial differences among species in this respect (Tóth et al., 2018). The basal Asc concentration in green algae is very low compared with higher plants (approximately $60 \mu \mathrm{M}$ was detected here, whereas the cellular Asc concentration is about $5 \mathrm{mM}$ in non-stressed plants) (Zechmann et al., 2011).

As shown previously (Nagy et al., 2016) and here in Figure 30, Asc inactivates the $\mathrm{OEC}$ in green algae when present in the $\mathrm{mM}$ range; this does not occur in higher plants, in spite the fact that the Asc concentration is about 10 to 20 $\mathrm{mM}$ in their chloroplasts (Zechmann et al., 2011). The reason for this important difference is not yet clear, although the structural differences between the extrinsic OEC proteins in higher plants and green algae may be an important factor (Tóth et al., 2018). 


\subsection{3) The decline of PSII activity may involve donor-side induced}

\section{photoinhibition}

Once the OEC is inactivated, Asc may continuously provide electrons to $\mathrm{Tyr}_{\mathrm{z}}{ }^{+}$. The electron donation by Asc to PSII is rather slow, however: depending on the concentration, it occurs with a half-life time of approximately 20-100 ms (Tóth et al., 2009). For this reason, Asc cannot fully prevent the accumulation of $\mathrm{Tyr}_{\mathrm{z}}{ }^{+}$and $\mathrm{P} 680^{+}$upon illumination. The presence of these strongly oxidizing species leads to donor-side induced photoinhibition, resulting in the relatively rapid degradation of PSII reaction center proteins, including PsbA, PSBO, CP43 (Figure 27) and possibly several more subunits. Upon sulphur deprivation, the expression level of the nuclearencoded PSBO subunit, which normally possesses a relatively long lifetime (Nelson et al., 2014), is also downregulated (Toepel et al., 2013), possibly contributing to the decrease in PSII activity. The rapid loss of CP43 was unexpected; in the absence of this protein, PSII is destabilized (Sugimoto and Takahashi, 2003), which may also contribute to the loss of photosynthetic activity.

The loss of PSII activity could be regarded as a deleterious effect of sulphur deprivation; however, it should be considered that upon the downregulation of PSII activity, overexcitation and further photodamage are minimized. The importance of this process is best demonstrated by the sacl and snrk2.1 mutants, which are unable to downregulate their photosynthetic activity upon sulphur deprivation, resulting in increased ${ }^{1} \mathrm{O}_{2}$ production and cell death on a timescale of days (Davies et al., 1996; Gonzalez-Ballester et al., 2008). Altogether, the metabolic changes downregulating cell proliferation and photosynthetic activity may serve to maintain the cellular sulphur content at a certain level, and to avoid any more substantial damage.

Excess excitation energy may also be dissipated at the acceptor side of PSI, via various $\mathrm{O}_{2}$-dependent mechanisms, including the Mehler reaction, the malate shuttle, the plastid terminal oxidase and the flavodiiron-dependent photoreduction pathways (Curien et al., 2016; Erickson et al., 2015); however, under hypoxic conditions, commonly occurring in the habitats of green algae, electron transport to the hydrogenases may also represent a safety valve (Godaux et al., 2015) instead of the $\mathrm{O}_{2}$-dependent pathways. 


\section{3) Determination of the role of Asc in the induction of NPQ}

We aimed at gaining insights into the involvement of Asc in the induction of NPQ in green algae by studying the responses of an Asc-deficient $C$. reinhardtii strain. As for our previous studies (Vidal-Meireles et al., 2017) we selected VTC2, encoding GDP-L-galactose phosphorylase, as a target gene. We opted for the insertional mutants available from the CLiP library ( $\mathrm{Li}$ et al., 2016a), because it may contain actual knockout lines and the mutants are assumed to be more stable than amiRNA transformants. Indeed, we have observed that our VTC2-amiRNA became silenced after about two years.

In our selected VTC2 insertional mutant (VTC2-CDS6), the Asc content was reduced to about $10 \%$ of the control strains under standard growth conditions (Figure $33 \mathrm{~A}$ ), and unlike for the VTC2-amiRNA transformants (Figure 51), the VTC2 transcript was not detected in the Asc-deficient mutant under control conditions, and it was only barely detectable upon $\mathrm{H}_{2} \mathrm{O}_{2}$ treatment (Figure $33 \mathrm{~B}$ ). Unlike for the VTC2-amiRNA transformants (Figure 14), in these lines Asc-deficiency was not accompanied by loss of $\mathrm{Chl}$ or changes in the cell size (Figure 35), which might be related to the fact that the insertional mutant is a cell-wall containing strain. We additionally confirmed that Asc deficiency leads to decreased photosynthetic electron transport rates (Figure 18), which can be recovered by external supplementation of Asc to the cells. We also showed that the relative amounts of various photosynthetic subunits were similar in the Asc-deficient mutant and WT under all growth conditions (Figure 18).

\subsection{1) The effects of Asc deficiency on NPQ in cultures grown under} photomixotrophic conditions at normal light

Through its role as a cofactor of violaxanthin deepoxidase, Asc also contributes to NPQ in higher plants (Müller-Moulé et al., 2002), but since $C$. reinhardtii VDE differs from the plant-type enzyme ( $\mathrm{Li}$ et al., 2016b), it was unknown whether Asc was required as a co-factor of CrVDE and if it was a limiting factor for NPQ development in green algae.

The results with our insertional Asc-deficient mutants show that CrVDE activity was not limited by Asc deficiency in C. reinhardtii under photomixotrophic growth (Figure 38). 
It has been proposed that, in contrast to higher plants, state transitions, rather than high-energy state quenching $(\mathrm{qE})$ constitute the major form of NPQ in $C$. reinhardtii, especially under $\mathrm{CO}_{2}$-replete conditions (Finazzi et al., 2006). However, we found that qZ was the main NPQ mechanism for cells grown in TAP medium at normal light intensity (see chapter 4.3.2). The role of $\mathrm{qE}$ under these conditions is minor, and the relative amounts of LHCSR3 protein, essential for $\mathrm{qE}$ development (Xue et al., 2015) are very low both in WT and Asc-deficient mutant (Figure 36). The importance of CrVDE under these conditions is revealed by the studies on the $N P Q 1$ C. reinhardtii mutant, unable to perform de-epoxidation of violaxanthin; when this mutant is subjected to $530 \mu$ mole photons $\mathrm{m}^{-2} \mathrm{~s}^{-1}$ with no prior adaptation to high light, it develops strong qI, bleaching, and loss of photosynthetic activity and carotenoids (Figure 42). On the other hand, the mutant $s t t 7$, unable to perform state transition, is capable of growing under these conditions and does not show decreased NPQ (Figure 41). Additionally, the WT and Asc-deficient mutant show no significant changes in the $684 \mathrm{~nm} / 710 \mathrm{~nm}$ ratio of the $77 \mathrm{~K}$ fluorescence spectra, indicating that qT is probably not induced under these conditions (igure 40).

The slow NPQ component was larger in the Asc-deficient mutant than in the WT (Figure 37). To investigate the reason behind this, we treated the cells with $\mathrm{H}_{2} \mathrm{O}_{2}$ and catalase (Figure 43). We observed that $\mathrm{H}_{2} \mathrm{O}_{2}$ treatment caused an increase in NPQ in both strains (Figure $43 \mathrm{~A}$ ); on the other hand, the catalase treatment was particularly effective in reducing the NPQ in the Asc-deficient mutant (Figure $43 \mathrm{~B}$ ). In the VTC2-amiRNA mutants we have observed that Asc-deficiency is accompanied by a constitutive increase in the intracellular $\mathrm{H}_{2} \mathrm{O}_{2}$ content (Vidal-Meireles et al., 2017; section 4.1.6). These results suggest that under Asc-deficiency $\mathrm{H}_{2} \mathrm{O}_{2}$ can enhance the slow NPQ induction in $C$. reinhardtii, possibly due to some sort of qI induction which overlaps the qZ formation.

\subsection{2) The effects of Asc deficiency on NPQ in cultures grown under} photoautotrophic conditions at normal light

As it was observed for the cultures grown under photomixotrophic conditions (Figure 38), there are no differences in the de-epoxidation levels of the WT and VTC2-CDS6 strains, meaning that CrVDE activity was also not limited by Asc deficiency in C. reinhardtii under photoautotrophic growth (Figure $45 \mathrm{~A}$ ). 
Under these conditions $\mathrm{qE}$ induction was higher (Figure 44), which was accompanied by the increase in the LHCSR3 protein abundance (Figure 36), and there were no differences in the qZ component of the Asc-deficient mutant and its WT strain. The identity of $\mathrm{qE}$ was confirmed by testing the NPQ4 mutant, lacking LHCSR3, that had no significant fast fluorescence quenching (Figure 49). The slow component was missing from the $N P Q 1$ mutant, further suggesting it was due to $\mathrm{qZ}$.

In order to rule out the involvement of qT in the NPQ induction, we tested the stt7 mutant under these conditions, and as observed before (Figure 41) this strain was able to develop NPQ at a slow rate (Figure 47), thus confirming that it was not due to qT. Furthermore, the analysis of the $684 \mathrm{~nm} / 710 \mathrm{~nm}$ ratio of the $77 \mathrm{~K}$ fluorescence spectra show that the cells underwent state II - state I transition in the light (Figure 45 B), a phenomenon that should decrease fluorescence quenching instead of increasing it; since in the dark the cells went back to state II, it is possible that here there is some qT induction, which is responsible for the incomplete recovery of the fluorescence quenching by the end of the experimental protocol.

The carotenoid content of the WT and VTC2-CDS6 mutants (Figure 46) remained stable throughout the protocol. In addition to this, the $\mathrm{H}_{2} \mathrm{O}_{2}$ and catalase treatments had no significant effect in both strains, suggesting that ROS are efficiently de-toxified under these conditions and that qI is not responsible for the slow NPQ induction observed here.

\subsection{3) The effects of Asc deficiency on NPQ in cultures grown under photoautotrophic conditions at high light}

Under excess illumination, the thylakoid lumen becomes more acidic (Muller, 2001), and the decrease in $\mathrm{pH}$ of the lumen acts as a signal that triggers the protonation of the PSII-associated proteins involved in $\mathrm{qE}$ (Horton et al., 1994, 1996). Under photoautotrophic growth at high light intensities, we have found that LHCSR3 protein accumulated strongly (Figure 36), enhancing qE induction, both in the Asc-deficient mutant and in the WT (Figure $52 \mathrm{~A}$ ). It was also possible to identify a slow NPQ component, which was induced mostly in the Asc-deficient mutant (Figure 52). The reason behind was studied in more detail.

Under photoautotrophic and high light conditions, we found that there is no zeaxanthin formation, as seen by the maintenance of the de-epoxidation levels at a 
constant value (Figure $53 \mathrm{~A}$ ), both in the WT and Asc-deficient mutant, so qZ was ruled out as the slow NPQ component (Figure $52 \mathrm{~A}$ ).

Although the stt7 mutant gown under these conditions lacked the slow component (Figure 55), qT was also ruled out from the Asc-deficient mutant because the $684 \mathrm{~nm} / 710 \mathrm{~nm}$ ratio of the $77 \mathrm{~K}$ fluorescence spectra remained constant throughout the whole protocol (Figure $53 \mathrm{~B}$ ).

Finally, to test whether qI was induced under these conditions in case of Asc-deficiency, we measured the carotenoid content of the cells (Figure 54) and the

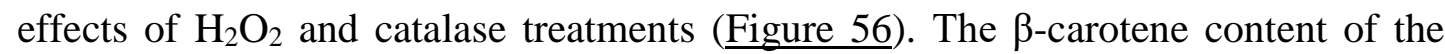
Asc-deficient mutant was significantly lower than the WT strain (Figure 54), suggesting once again that the VTC2-CDS6 mutant has a higher intracellular $\mathrm{H}_{2} \mathrm{O}_{2}$ content (Vidal-Meireles et al., 2017; section 4.1.6). While the $\mathrm{H}_{2} \mathrm{O}_{2}$ treatment had the same effect for both strains (Figure 56 A), keeping the fluorescence constantly quenched at a high level, catalase treatment strongly decreased the NPQ induction of the Asc-deficient mutant (Figure 56 B), suggesting that under high light growth Ascdeficiency causes qI induction in $C$. reinhardtii. 


\section{6.) CONCLUSIONS}

Ascorbate is of vital importance to the cellular functions of both animals and plants as an essential scavenger of ROS and as a cofactor of several enzymes, which catalyze a large number of enzymatic reactions in the cell. Asc biosynthesis and its regulation are poorly studied in non-vascular plants, and even though it was known that the genome of the model green alga $C$. reinhardtii encodes all the enzymes of the Smirnoff-Wheeler Asc biosynthesis pathway, no direct evidence for its physiological function was available. In addition, in this thesis it was also demonstrated that the regulation of Asc biosynthesis has evolved markedly different mechanisms in $C$. reinhardtii than in higher plants:

- The expression of the VTC2 gene of C. reinhardtii is not directly influenced by the photosynthetic electron transport chain;

- In contrast to higher plants, VTC2 transcript abundance is not under circadian control in C. reinhardtii;

- Upon oxidative stress, VTC2 is strongly upregulated, allowing a very rapid Asc accumulation;

- There is no negative feedback mechanism in the physiological Asc concentration range.

Under stress conditions, such as sulphur deprivation, C. reinhardtii can increase their Asc concentration to levels that may lead to inactivation of the OEC. Based on our previous results (Nagy et al., 2016), we aimed to better understand the role of Asc in the establishment of hypoxia and initiation of $\mathrm{H}_{2}$ production. We have found that:

- The moderate decrease in sulphur content is unlikely to be the main cause for substantial PsbA loss upon sulphur deprivation as it is generally assumed;

- PsbA has a discernible turnover during sulphur-deprivation;

- The transcript abundance of the VTC2 gene increases upon sulphur deprivation, which leads to Asc accumulation up to the $\mathrm{mM}$ range;

- The decline of PSII activity may be caused by donor-side induced photoinhibition exerted by the strong Asc accumulation. 
Ascorbate plays an important role in the photosynthesis of seed plants and acts as a cofactor of VDE (Müller-Moulé et al., 2002). This enzyme, activated upon thylakoid lumen acidification, is responsible for the conversion of violaxanthin to zeaxanthin and plays an essential role in the qE component of NPQ (Müller-Moulé et al., 2002). C. reinhardtii has a VDE enzyme related to a lycopene cyclase of photosynthetic bacteria, which is located on the stromal side of the thylakoid membrane ( $\mathrm{Li}$ et al., 2016b) and the role of Asc in NPQ of green algae is poorly studied. Here we have found that:

- As opposed to seed plants, in the green alga C. reinhardtii Asc is not required as a co-factor for VDE;

- Under photomixotrophic growth at normal light intensities, $\mathrm{qZ}$ is the main NPQ component, and $\mathrm{H}_{2} \mathrm{O}_{2}$ enhances the slow component of NPQ;

- When the cultures are grown under photoautotrophic conditions at normal light intensities, $\mathrm{qE}$ is enhanced and $\mathrm{qZ}$ is still induced, but under these conditions $\mathrm{H}_{2} \mathrm{O}_{2}$ is either efficiently detoxified by the cells or has no effect on the slow NPQ component;

- If the cultures are kept under photoautotrophic conditions at high light intensities, $\mathrm{qE}$ induction is maximal and $\mathrm{qZ}$ is no longer induced. Under these conditions, lack of Asc causes qI induction which might be triggered by $\mathrm{H}_{2} \mathrm{O}_{2}$ accumulation. 


\section{7.) Bibliography}

Antal, T.K., Krendeleva, T.E., and Tyystjärvi, E. (2015). Multiple regulatory mechanisms in the chloroplast of green algae: relation to hydrogen production. Photosynth. Res. 125, 357-381.

Anwaruzzaman, M., Chin, B.L., Li, X.-P., Lohr, M., Martinez, D.A., and Niyogi, K.K. (2004). Genomic analysis of mutants affecting xanthophyll biosynthesis and regulation of photosynthetic light harvesting in Chlamydomonas reinhardtii. Photosynth. Res. 82, 265-276.

Arató, A., Bondarava, N., and Krieger-Liszkay, A. (2004). Production of reactive oxygen species in chloride- and calcium-depleted photosystem II and their involvement in photoinhibition. BBA - Bioenerg. 1608, 171-180.

Aro, E.-M., Virgin, I., and Andersson, B. (1993). Photoinhibition of Photosystem II. Inactivation, protein damage and turnover. BBA - Bioenerg. 1143, $113-134$.

Asada, K. (2006). Production and Scavenging of Reactive Oxygen Species in Chloroplasts and Their Functions. Plant Physiol. 141, 391-396.

Ausubel, F.M., Brent, R., Kingston, R.E., Moore, D.D., Seidman, J.G., Smith, J.A., and Struhl, K. (2001). Current Protocols in Molecular Biology (Hoboken, NJ, USA: John Wiley \& Sons, Inc.).

Ballottari, M., Truong, T.B., De Re, E., Erickson, E., Stella, G.R., Fleming, G.R., Bassi, R., and Niyogi, K.K. (2016). Identification of pH-sensing Sites in the Light Harvesting Complex Stress-related 3 Protein Essential for Triggering Nonphotochemical Quenching in Chlamydomonas reinhardtii. J. Biol. Chem. 291, 73347346.

Barahimipour, R., Strenkert, D., Neupert, J., Schroda, M., Merchant, S.S., and Bock, R. (2015). Dissecting the contributions of GC content and codon usage to gene expression in the model alga Chlamydomonas reinhardtii. Plant J. 84, 704-717.

Barra, M., Haumann, M., and Dau, H. (2005). Specific loss of the extrinsic 18 $\mathrm{KDa}$ protein from Photosystem II upon heating to $47{ }^{\circ} \mathrm{C}$ causes inactivation of oxygen evolution likely due to Ca release from the Mn-complex. Photosynth. Res. 84, 231-237. 
Barth, C. (2004). The Timing of Senescence and Response to Pathogens Is Altered in the Ascorbate-Deficient Arabidopsis Mutant vitamin c-1. Plant Physiol. $134,1784-1792$.

Blaby, I.K., Blaby-Haas, C.E., Pérez-Pérez, M.E., Schmollinger, S., FitzGibbon, S., Lemaire, S.D., and Merchant, S.S. (2015). Genome-wide analysis on Chlamydomonas reinhardtii reveals the impact of hydrogen peroxide on protein stress responses and overlap with other stress transcriptomes. Plant J. 84, 974-988.

Blubaugh, D.J., Atamian, M., Babcock, G.T., Golbeck, J.H., and Cheniae, G.M. (1991). Photoinhibition of hydroxylamine-extracted photosystem II membranes: identification of the sites of photodamage. Biochemistry (Mosc.) 30, 7586-7597.

Briantais, J.-M., Vernotte, C., Picaud, M., and Krause, G.H. (1979). A quantitative study of the slow decline of chlorophyll $a$ fluorescence in isolated chloroplasts. BBA - Bioenerg. 548, 128-138.

Bulley, S., and Laing, W. (2016). The regulation of ascorbate biosynthesis. Curr. Opin. Plant Biol. 33, 15-22.

Caregnato, F.F., Bortolin, R.C., Divan Junior, A.M., and Moreira, J.C.F. (2013). Exposure to elevated ozone levels differentially affects the antioxidant capacity and the redox homeostasis of two subtropical Phaseolus vulgaris L. varieties. Chemosphere 93, 320-330.

Charles Dismukes, G., and van Willigen, R.T. (2006). Manganese: The Oxygen-Evolving Complex. In Encyclopedia of Inorganic Chemistry, R.B. King, R.H. Crabtree, C.M. Lukehart, D.A. Atwood, and R.A. Scott, eds. (Chichester, UK: John Wiley \& Sons, Ltd)

Chi, W., Feng, P., Ma, J., and Zhang, L. (2015). Metabolites and chloroplast retrograde signaling. Curr. Opin. Plant Biol. 25, 32-38.

Christensen, A.C. (2005). Dual-Domain, Dual-Targeting Organellar Protein Presequences in Arabidopsis Can Use Non-AUG Start Codons. Plant Cell Online 17, $2805-2816$.

Conklin, P.L., Saracco, S.A., Norris, S.R., and Last, R.L. (2000). Identification of ascorbic acid-deficient Arabidopsis thaliana mutants. Genetics 154, $847-856$. 
Curien, G., Flori, S., Villanova, V., Magneschi, L., Giustini, C., Forti, G., Matringe, M., Petroutsos, D., Kuntz, M., and Finazzi, G. (2016). The Water to Water Cycles in Microalgae. Plant Cell Physiol. pcw048.

Davies, J.P., Yildiz, F.H., and Grossman, A. (1996). Sac1, a putative regulator that is critical for survival of Chlamydomonas reinhardtii during sulfur deprivation. EMBO J. 15, 2150-2159.

Del Río, L.A., and López-Huertas, E. (2016). ROS Generation in Peroxisomes and its Role in Cell Signaling. Plant Cell Physiol. 57, 1364-1376.

Depege, N. (2003). Role of Chloroplast Protein Kinase Stt7 in LHCII Phosphorylation and State Transition in Chlamydomonas. Science 299, 1572-1575.

Dowdle, J., Ishikawa, T., Gatzek, S., Rolinski, S., and Smirnoff, N. (2007). Two genes in Arabidopsis thaliana encoding GDP-L-galactose phosphorylase are required for ascorbate biosynthesis and seedling viability. Plant J. Cell Mol. Biol. 52, 673-689.

Drop, B., Yadav K.N., S., Boekema, E.J., and Croce, R. (2014). Consequences of state transitions on the structural and functional organization of Photosystem I in the green alga Chlamydomonas reinhardtii. Plant J. 78, 181-191.

Ducruet, J.-M., and Vass, I. (2009). Thermoluminescence: experimental. Photosynth. Res. 101, 195-204.

Dumville, J.C., and Fry, S.C. (2003). Solubilisation of tomato fruit pectins by ascorbate: a possible non-enzymic mechanism of fruit softening. Planta 217, 951961.

Enami, I., Kitamura, M., Tomo, T., Isokawa, Y., Ohta, H., and Katoh, S. (1994). Is the primary cause of thermal inactivation of oxygen evolution in spinach PSII membranes release of the extrinsic $33 \mathrm{kDa}$ protein or of Mn? BBA - Bioenerg. $1186,52-58$.

Erickson, E., Wakao, S., and Niyogi, K.K. (2015). Light stress and photoprotection in Chlamydomonas reinhardtii. Plant J. 82, 449-465.

Farré, G., Blancquaert, D., Capell, T., Van Der Straeten, D., Christou, P., and Zhu, C. (2014). Engineering Complex Metabolic Pathways in Plants. Annu. Rev. Plant Biol. 65, 187-223.

Fernie, A.R., and Tóth, S.Z. (2015). Identification of the Elusive Chloroplast Ascorbate Transporter Extends the Substrate Specificity of the PHT Family. Mol. Plant 8, 674-676. 
Ferreira, K.N. (2004). Architecture of the Photosynthetic Oxygen-Evolving Center. Science 303, 1831-1838.

Finazzi, G. (2002). Involvement of state transitions in the switch between linear and cyclic electron flow in Chlamydomonas reinhardtii. EMBO Rep. 3, 280285.

Finazzi, G., Johnson, G.N., Dall'Osto, L., Zito, F., Bonente, G., Bassi, R., and Wollman, F.-A. (2006). Nonphotochemical Quenching of Chlorophyll Fluorescence in Chlamydomonas reinhardtii. Biochemistry (Mosc.) 45, 1490-1498.

Fleischmann, M.M., Ravanel, S., Delosme, R., Olive, J., Zito, F., Wollman, F.A., and Rochaix, J.D. (1999). Isolation and characterization of photoautotrophic mutants of Chlamydomonas reinhardtii deficient in state transition. J. Biol. Chem. 274, 30987-30994.

Forestier, M., King, P., Zhang, L., Posewitz, M., Schwarzer, S., Happe, T., Ghirardi, M.L., and Seibert, M. (2003). Expression of two [Fe]-hydrogenases in Chlamydomonas reinhardtii under anaerobic conditions: Expression of a second [Fe]-hydrogenase in C. reinhardtii. Eur. J. Biochem. 270, 2750-2758.

Fotopoulos, V., De Tullio, M.C., Barnes, J., and Kanellis, A.K. (2008). Altered stomatal dynamics in ascorbate oxidase over-expressing tobacco plants suggest a role for dehydroascorbate signalling. J. Exp. Bot. 59, 729-737.

Foyer, C.H., and Noctor, G. (2011). Ascorbate and Glutathione: The Heart of the Redox Hub. Plant Physiol. 155, 2-18.

Foyer, C.H., and Shigeoka, S. (2011). Understanding Oxidative Stress and Antioxidant Functions to Enhance Photosynthesis. Plant Physiol. 155, 93-100.

Gallie, D.R. (2013). The role of 1 -ascorbic acid recycling in responding to environmental stress and in promoting plant growth. J. Exp. Bot. 64, 433-443.

Gao, Q., and Zhang, L. (2008). Ultraviolet-B-induced oxidative stress and antioxidant defense system responses in ascorbate-deficient vtcl mutants of Arabidopsis thaliana. J. Plant Physiol. 165, 138-148.

Gao, Y., Badejo, A.A., Shibata, H., Sawa, Y., Maruta, T., Shigeoka, S., Page, M., Smirnoff, N., and Ishikawa, T. (2011). Expression Analysis of the VTC2 and VTC5 Genes Encoding GDP-L-Galactose Phosphorylase, an Enzyme Involved in Ascorbate Biosynthesis, in Arabidopsis thaliana. Biosci. Biotechnol. Biochem. 75, 1783-1788. 
Gest, N., Gautier, H., and Stevens, R. (2013). Ascorbate as seen through plant evolution: the rise of a successful molecule? J. Exp. Bot. 64, 33-53.

Ghysels, B., Godaux, D., Matagne, R.F., Cardol, P., and Franck, F. (2013). Function of the Chloroplast Hydrogenase in the Microalga Chlamydomonas: The Role of Hydrogenase and State Transitions during Photosynthetic Activation in Anaerobiosis. PLoS ONE 8, e64161.

Godaux, D., Bailleul, B., Berne, N., and Cardol, P. (2015). Induction of Photosynthetic Carbon Fixation in Anoxia Relies on Hydrogenase Activity and Proton-Gradient Regulation-Like1-Mediated Cyclic Electron Flow in Chlamydomonas reinhardtii. Plant Physiol. 168, 648-658.

Gonzalez-Ballester, D., Pollock, S.V., Pootakham, W., and Grossman, A.R. (2008). The Central Role of a SNRK2 Kinase in Sulfur Deprivation Responses. Plant Physiol. 147, 216-227.

Green, M.A., and Fry, S.C. (2005). Vitamin C degradation in plant cells via enzymatic hydrolysis of 4-O-oxalyl-1-threonate. Nature 433, 83-87.

Grewe, S., Ballottari, M., Alcocer, M., D’Andrea, C., Blifernez-Klassen, O., Hankamer, B., Mussgnug, J.H., Bassi, R., and Kruse, O. (2014). Light-Harvesting Complex Protein LHCBM9 Is Critical for Photosystem II Activity and Hydrogen Production in Chlamydomonas reinhardtii. Plant Cell 26, 1598-1611.

Guan, C., Ji, J., Zhang, X., Li, X., Jin, C., Guan, W., and Wang, G. (2015). Positive feedback regulation of a Lycium chinense-derived VDE gene by droughtinduced endogenous $\mathrm{ABA}$, and over-expression of this VDE gene improve droughtinduced photo-damage in Arabidopsis. J. Plant Physiol. 175, 26-36.

Harris, E.H. (2001). Chlamydomonas as a model organism. Annu. Rev. Plant Physiol. Plant Mol. Biol. 52, 363-406.

Hieber, A.D., Bugos, R.C., and Yamamoto, H.Y. (2000). Plant lipocalins: violaxanthin de-epoxidase and zeaxanthin epoxidase. BBA - Protein Struct. Mol. Enzymol. 1482, 84-91.

Horton, P., and Ruban, A. (2005). Molecular design of the photosystem II light-harvesting antenna: photosynthesis and photoprotection. J. Exp. Bot. 56, 365373.

Horton, P., Ruban, A.V., and Walters, R.G. (1994). Regulation of Light Harvesting in Green Plants (Indication by Nonphotochemical Quenching of Chlorophyll Fluorescence). Plant Physiol. 106, 415-420. 
Horton, P., Ruban, A.V., and Walters, R.G. (1996). Regulation of Light Harvesting in Green Plants. Annu. Rev. Plant Physiol. Plant Mol. Biol. 47, 655-684.

Huang, C., He, W., Guo, J., Chang, X., Su, P., and Zhang, L. (2005). Increased sensitivity to salt stress in an ascorbate-deficient Arabidopsis mutant. J. Exp. Bot. 56, 3041-3049.

Ivanov, B., and Edwards, G. (2000). Influence of ascorbate and the Mehler peroxidase reaction on non-photochemical quenching of chlorophyll fluorescence in maize mesophyll chloroplasts. Planta 210, 765-774.

Iwai, M., Kato, N., and Minagawa, J. (2007). Distinct physiological responses to a high light and low $\mathrm{CO}_{2}$ environment revealed by fluorescence quenching in photoautotrophically grown Chlamydomonas reinhardtii. Photosynth. Res. 94, 307314.

Iwakawa, H., and Tomari, Y. (2013). Molecular Insights into microRNAMediated Translational Repression in Plants. Mol. Cell 52, 591-601.

Izawa, S. (1980). Acceptors and donors and chloroplast electron transport. Methods in Enzymology, (Elsevier), pp. 413-434.

Järvi, S., Suorsa, M., and Aro, E.-M. (2015). Photosystem II repair in plant chloroplasts - Regulation, assisting proteins and shared components with photosystem II biogenesis. BBA - Bioenerg. 1847, 900-909.

Jeffrey, S.W., Mantoura, R.F.C., Wright, S.W., and Unesco (2005). Phytoplankton pigments in oceanography: guidelines to modern methods (Paris: Unesco Publ).

Jegerschöld, C., and Styring, S. (1996). Spectroscopic Characterization of Intermediate Steps Involved in Donor-Side-Induced Photoinhibition of Photosystem II. Biochemistry (Mosc.) 35, 7794-7801.

Jimenez, A., Hernandez, J.A., Del Rio, L.A., and Sevilla, F. (1997). Evidence for the Presence of the Ascorbate-Glutathione Cycle in Mitochondria and Peroxisomes of Pea Leaves. Plant Physiol. 114, 275-284.

Kiddle, G., Pastori, G.M., Bernard, S., Pignocchi, C., Antoniw, J., Verrier, P.J., and Foyer, C.H. (2003). Effects of Leaf Ascorbate Content on Defense and Photosynthesis Gene Expression in Arabidopsis thaliana. Antioxid. Redox Signal. 5, 23-32.

Kindle, K.L. (1990). High-frequency nuclear transformation of Chlamydomonas reinhardtii. Proc. Natl. Acad. Sci. 87, 1228-1232. 
Kiyota, M., Numayama, N., and Goto, K. (2006). Circadian rhythms of the Lascorbic acid level in Euglena and spinach. J. Photochem. Photobiol. B 84, 197-203.

Klimov, V.V., Shafiev, M.A., and Allakhverdiev, S.I. (1990). Photoinactivation of the reactivation capacity of photosystem II in pea subchloroplast particles after a complete removal of manganese. Photosynth. Res. 23, 59-65.

Kobayashi, Y., Dokiya, Y., Kumazawa, Y., and Sugita, M. (2002). Non-AUG translation initiation of mRNA encoding plastid-targeted phage-type RNA polymerase in Nicotiana sylvestris. Biochem. Biophys. Res. Commun. 299, 57-61.

Kopka, J., Schauer, N., Krueger, S., Birkemeyer, C., Usadel, B., Bergmuller, E., Dormann, P., Weckwerth, W., Gibon, Y., Stitt, M., et al. (2005). GMD@CSB.DB: the Golm Metabolome Database. Bioinformatics 21, 1635-1638.

Kosourov, S.N., and Seibert, M. (2009). Hydrogen photoproduction by nutrient-deprived Chlamydomonas reinhardtii cells immobilized within thin alginate films under aerobic and anaerobic conditions. Biotechnol. Bioeng. 102, 50-58.

Kosourov, S., Tsygankov, A., Seibert, M., and Ghirardi, M.L. (2002). Sustained hydrogen photoproduction by Chlamydomonas reinhardtii: Effects of culture parameters. Biotechnol. Bioeng. 78, 731-740.

Kovács, L., Ayaydin, F., Kálai, T., Tandori, J., Kós, P.B., and Hideg, É. (2014). Assessing the Applicability of Singlet Oxygen Photosensitizers in Leaf Studies. Photochem. Photobiol. 90, 129-136.

Kovács, L., Vidal-Meireles, A., Nagy, V., and Tóth, S.Z. (2016). Quantitative Determination of Ascorbate from the Green Alga Chlamydomonas reinhardtii by HPLC. Bio-Protoc. 6.

Kramer, D.A., Sacksteder, and Jeffrey A. (1999). How acidic is the lumen? Photosynth. Res. 60, 151-163.

Laing, W.A., Martínez-Sánchez, M., Wright, M.A., Bulley, S.M., Brewster, D., Dare, A.P., Rassam, M., Wang, D., Storey, R., Macknight, R.C., et al. (2015). An Upstream Open Reading Frame Is Essential for Feedback Regulation of Ascorbate Biosynthesis in Arabidopsis. Plant Cell 27, 772-786.

Ledford, H.K., Chin, B.L., and Niyogi, K.K. (2007). Acclimation to Singlet Oxygen Stress in Chlamydomonas reinhardtii. Eukaryot. Cell 6, 919-930.

Lee, R.E. (2008). Phycology (Cambridge, United Kingdom New York: Cambridge University Press). 
Leisinger, U., Rüfenacht, K., Fischer, B., Pesaro, M., Spengler, A., Zehnder, A.J.B., and Eggen, R.I.L. (2001). The glutathione peroxidase homologous gene from Chlamydomonas reinhardtii is transcriptionally up-regulated by singlet oxygen. Plant Mol. Biol. 46, 395-408.

Lemeille, S., Willig, A., Depège-Fargeix, N., Delessert, C., Bassi, R., and Rochaix, J.-D. (2009). Analysis of the Chloroplast Protein Kinase Stt7 during State Transitions. PLoS Biol. 7, e1000045.

Lemeille, S., Turkina, M.V., Vener, A.V., and Rochaix, J.-D. (2010). Stt7dependent phosphorylation during state transitions in the green alga Chlamydomonas reinhardtii. Mol. Cell. Proteomics MCP 9, 1281-1295.

Li, S., Liu, L., Zhuang, X., Yu, Y., Liu, X., Cui, X., Ji, L., Pan, Z., Cao, X., Mo, B., et al. (2013). MicroRNAs Inhibit the Translation of Target mRNAs on the Endoplasmic Reticulum in Arabidopsis. Cell 153, 562-574.

Li, X., Zhang, R., Patena, W., Gang, S.S., Blum, S.R., Ivanova, N., Yue, R., Robertson, J.M., Lefebvre, P.A., Fitz-Gibbon, S.T., et al. (2016a). An Indexed, Mapped Mutant Library Enables Reverse Genetics Studies of Biological Processes in Chlamydomonas reinhardtii. Plant Cell 28, 367-387.

Li, Z., Peers, G., Dent, R.M., Bai, Y., Yang, S.Y., Apel, W., Leonelli, L., and Niyogi, K.K. (2016b). Evolution of an atypical de-epoxidase for photoprotection in the green lineage. Nat. Plants 2, 16140.

López-Carbonell, M., Munné-Bosch, S., and Alegre, L. (2006). The Ascorbate-deficient vtc-1 Arabidopsis Mutant Shows Altered ABA Accumulation in Leaves and Chloroplasts. J. Plant Growth Regul. 25, 137-144.

Luedemann, A., Strassburg, K., Erban, A., and Kopka, J. (2008). TagFinder for the quantitative analysis of gas chromatography-mass spectrometry (GC-MS)based metabolite profiling experiments. Bioinformatics 24, 732-737.

Ma, X., Cao, X., Mo, B., and Chen, X. (2013). Trip to ER: MicroRNAmediated translational repression in plants. RNA Biol. 10, 1586-1592.

Mano, J., Hideg, É., and Asada, K. (2004). Ascorbate in thylakoid lumen functions as an alternative electron donor to photosystem II and photosystem I. Arch. Biochem. Biophys. 429, 71-80.

Mastrobuoni, G., Irgang, S., Pietzke, M., Aßmus, H.E., Wenzel, M., Schulze, W.X., and Kempa, S. (2012). Proteome dynamics and early salt stress response of the photosynthetic organism Chlamydomonas reinhardtii. BMC Genomics 13, 215. 
Matsuo, T., Okamoto, K., Onai, K., Niwa, Y., Shimogawara, K., and Ishiura, M. (2008). A systematic forward genetic analysis identified components of the Chlamydomonas circadian system. Genes Dev. 22, 918-930.

McGarvey, D.J., and Christoffersen, R.E. (1992). Characterization and kinetic parameters of ethylene-forming enzyme from avocado fruit. J. Biol. Chem. 267, 5964-5967.

Melis, A. (1991). Dynamics of photosynthetic membrane composition and function. Biochim. Biophys. Acta BBA - Bioenerg. 1058, 87-106.

Melis, A., Zhang, L., Forestier, M., Ghirardi, M.L., and Seibert, M. (2000). Sustained Photobiological Hydrogen Gas Production upon Reversible Inactivation of Oxygen Evolution in the Green Alga Chlamydomonas reinhardtii. Plant Physiol. $122,127-136$.

Merchant, S.S., Prochnik, S.E., Vallon, O., Harris, E.H., Karpowicz, S.J., Witman, G.B., Terry, A., Salamov, A., Fritz-Laylin, L.K., Marechal-Drouard, L., et al. (2007). The Chlamydomonas Genome Reveals the Evolution of Key Animal and Plant Functions. Science 318, 245-250.

Mettler, T., Muhlhaus, T., Hemme, D., Schottler, M.-A., Rupprecht, J., Idoine, A., Veyel, D., Pal, S.K., Yaneva-Roder, L., Winck, F.V., et al. (2014). Systems Analysis of the Response of Photosynthesis, Metabolism, and Growth to an Increase in Irradiance in the Photosynthetic Model Organism Chlamydomonas reinhardtii. Plant Cell 26, 2310-2350.

Mirkovic, T., Ostroumov, E.E., Anna, J.M., van Grondelle, R., Govindjee, null, and Scholes, G.D. (2017). Light Absorption and Energy Transfer in the Antenna Complexes of Photosynthetic Organisms. Chem. Rev. 117, 249-293.

Mittler, R., Vanderauwera, S., Suzuki, N., Miller, G., Tognetti, V.B., Vandepoele, K., Gollery, M., Shulaev, V., and Van Breusegem, F. (2011). ROS signaling: the new wave? Trends Plant Sci. 16, 300-309.

Molnar, A., Bassett, A., Thuenemann, E., Schwach, F., Karkare, S., Ossowski, S., Weigel, D., and Baulcombe, D. (2009). Highly specific gene silencing by artificial microRNAs in the unicellular alga Chlamydomonas reinhardtii: Artificial miRNAs in Chlamydomonas. Plant J. 58, 165-174.

Muller, P. (2001). Non-Photochemical Quenching. A Response to Excess Light Energy. Plant Physiol. 125, 1558-1566. 
Müller-Moulé, P., Conklin, P.L., and Niyogi, K.K. (2002). Ascorbate deficiency can limit violaxanthin de-epoxidase activity in vivo. Plant Physiol. 128, 970-977.

Müller-Moulé, P., Golan, T., and Niyogi, K.K. (2004). Ascorbate-deficient mutants of Arabidopsis grow in high light despite chronic photooxidative stress. Plant Physiol. 134, 1163-1172.

Munné-Bosch, S. (2005). The role of alpha-tocopherol in plant stress tolerance. J. Plant Physiol. 162, 743-748.

Murata, N., Allakhverdiev, S.I., and Nishiyama, Y. (2012). The mechanism of photoinhibition in vivo: Re-evaluation of the roles of catalase, $\alpha$-tocopherol, nonphotochemical quenching, and electron transport. BBA - Bioenerg. 1817, 11271133.

Murik, O., Elboher, A., and Kaplan, A. (2014). Dehydroascorbate: a possible surveillance molecule of oxidative stress and programmed cell death in the green alga Chlamydomonas reinhardtii. New Phytol. 202, 471-484.

Nagy, V., Tengölics, R., Schansker, G., Rákhely, G., Kovács, K.L., Garab, G., and Tóth, S.Z. (2012). Stimulatory effect of ascorbate, the alternative electron donor of photosystem II, on the hydrogen production of sulphur-deprived Chlamydomonas reinhardtii. Int. J. Hydrog. Energy 37, 8864-8871.

Nagy, V., Vidal-Meireles, A., Tengölics, R., Rákhely, G., Garab, G., Kovács, L., and Tóth, S.Z. (2016). Ascorbate accumulation during sulphur deprivation and its effects on photosystem II activity and $\mathrm{H}_{2}$ production of the green alga Chlamydomonas reinhardtii. Plant Cell Environ. 39, 1460-1472.

Nagy, V., Podmaniczki, A., Vidal-Meireles, A., Tengölics, R., Kovács, L., Rákhely, G., Scoma, A., and Tóth, S.Z. (2018a). Water-splitting-based, sustainable and efficient $\mathrm{H}_{2}$ production in green algae as achieved by substrate limitation of the Calvin-Benson-Bassham cycle. Biotechnol. Biofuels 11 .

Nagy, V., Vidal-Meireles, A., Podmaniczki, A., Szentmihályi, K., Rákhely, G., Zsigmond, L., Kovács, L., and Tóth, S.Z. (2018b). The mechanism of photosystem II inactivation during sulphur deprivation-induced $\mathrm{H}_{2}$ production in Chlamydomonas reinhardtii. Plant J.

Nash, D., Miyao, M., and Murata, N. (1985). Heat inactivation of oxygen evolution in Photosystem II particles and its acceleration by chloride depletion and exogenous manganese. BBA - Bioenerg. 807, 127-133. 
Nelson, N., and Ben-Shem, A. (2004). The complex architecture of oxygenic photosynthesis. Nat. Rev. Mol. Cell Biol. 5, 971-982.

Nelson, C.J., Alexova, R., Jacoby, R.P., and Millar, A.H. (2014). Proteins with High Turnover Rate in Barley Leaves Estimated by Proteome Analysis Combined with in Planta Isotope Labeling. Plant Physiol. 166, 91-108.

Nguyen, A.V., Toepel, J., Burgess, S., Uhmeyer, A., Blifernez, O., Doebbe, A., Hankamer, B., Nixon, P., Wobbe, L., and Kruse, O. (2011). Time-Course Global Expression Profiles of Chlamydomonas reinhardtii during Photo-Biological $\mathrm{H}_{2}$ Production. PLoS ONE 6, e29364.

Nickelsen, J. (2005). Cell Biology: The Green Alga Chlamydomonas reinhardtii - A Genetic Model Organism. In Progress in Botany, K. Esser, U. Lüttge, W. Beyschlag, and J. Murata, eds. (Berlin/Heidelberg: Springer-Verlag), pp. 68-89.

Nilkens, M., Kress, E., Lambrev, P., Miloslavina, Y., Müller, M., Holzwarth, A.R., and Jahns, P. (2010). Identification of a slowly inducible zeaxanthin-dependent component of non-photochemical quenching of chlorophyll fluorescence generated under steady-state conditions in Arabidopsis. BBA - Bioenerg. 1797, 466-475.

Niyogi, K.K. (1997). Chlamydomonas Xanthophyll Cycle Mutants Identified by Video Imaging of Chlorophyll Fluorescence Quenching. Plant Cell Online 9, 1369-1380.

Niyogi, K.K. (1999). Photoprotection revisited: Genetic and Molecular Approaches. Annu. Rev. Plant Physiol. Plant Mol. Biol. 50, 333-359.

Obata, T., and Fernie, A.R. (2012). The use of metabolomics to dissect plant responses to abiotic stresses. Cell. Mol. Life Sci. 69, 3225-3243.

Ossowski, S., Schwab, R., and Weigel, D. (2008). Gene silencing in plants using artificial microRNAs and other small RNAs. Plant J. Cell Mol. Biol. 53, 674690.

Page, M., Sultana, N., Paszkiewicz, K., Florance, H., and Smirnoff, N. (2012). The influence of ascorbate on anthocyanin accumulation during high light acclimation in Arabidopsis thaliana: further evidence for redox control of anthocyanin synthesis: Influence of ascorbate on anthocyanin accumulation. Plant Cell Environ. 35, 388-404.

Pastori, G.M. (2003). Leaf Vitamin C Contents Modulate Plant Defense Transcripts and Regulate Genes That Control Development through Hormone Signaling. Plant Cell Online 15, 939-951. 
Peers, G., Truong, T.B., Ostendorf, E., Busch, A., Elrad, D., Grossman, A.R., Hippler, M., and Niyogi, K.K. (2009). An ancient light-harvesting protein is critical for the regulation of algal photosynthesis. Nature 462, 518-521.

Porra, R.J., Thompson, W.A., and Kriedemann, P.E. (1989). Determination of accurate extinction coefficients and simultaneous equations for assaying chlorophylls $a$ and $b$ extracted with four different solvents: verification of the concentration of chlorophyll standards by atomic absorption spectroscopy. BBA - Bioenerg. 975, 384-394.

Potters, G., Horemans, N., Caubergs, R.J., and Asard, H. (2000). Ascorbate and Dehydroascorbate Influence Cell Cycle Progression in a Tobacco Cell Suspension. Plant Physiol. 124, 17-20.

Pribil, M., Pesaresi, P., Hertle, A., Barbato, R., and Leister, D. (2010). Role of Plastid Protein Phosphatase TAP38 in LHCII Dephosphorylation and Thylakoid Electron Flow. PLoS Biol. 8, e1000288.

Rashid, A., and Popovic, R. (1995). Electron donation to photosystem II by diphenylcarbazide is inhibited both by the endogenous manganese complex and by exogenous manganese ions. Biochem. Cell Biol. Biochim. Biol. Cell. 73, 241-245.

Raymond, J., and Blankenship, R. (2008). The origin of the oxygen-evolving complex. Coord. Chem. Rev. 252, 377-383.

Rehman, A.U., Cser, K., Sass, L., and Vass, I. (2013). Characterization of singlet oxygen production and its involvement in photodamage of Photosystem II in the cyanobacterium Synechocystis PCC 6803 by histidine-mediated chemical trapping. BBA - Bioenerg. 1827, 689-698.

Renuka, N., Guldhe, A., Prasanna, R., Singh, P., and Bux, F. (2018). Microalgae as multi-functional options in modern agriculture: current trends, prospects and challenges. Biotechnol. Adv.

Roach, T., and Na, C.S. (2017). LHCSR3 affects de-coupling and re-coupling of LHCII to PSII during state transitions in Chlamydomonas reinhardtii. Sci. Rep. 7, 43145 .

Rousset, M., and Liebgott, P.-P. (2014). Engineering Hydrogenases for $\mathrm{H}_{2}$ Production: Bolts and Goals. In Microbial BioEnergy: Hydrogen Production, D. Zannoni, and R. De Philippis, eds. (Dordrecht: Springer Netherlands), pp. 43-77. 
Saroussi, S., Sanz-Luque, E., Kim, R.G., and Grossman, A.R. (2017). Nutrient scavenging and energy management: acclimation responses in nitrogen and sulfur deprived Chlamydomonas. Curr. Opin. Plant Biol. 39, 114-122.

Schansker, G., Tóth, S.Z., and Strasser, R.J. (2006). Dark recovery of the Chl $a$ fluorescence transient (OJIP) after light adaptation: The qT-component of nonphotochemical quenching is related to an activated photosystem I acceptor side. BBA - Bioenerg. 1757, 787-797.

Schansker, G., Tóth, S.Z., Holzwarth, A.R., and Garab, G. (2014). Chlorophyll $a$ fluorescence: beyond the limits of the QA model. Photosynth. Res. $120,43-58$.

Schmollinger, S., Strenkert, D., and Schroda, M. (2010). An inducible artificial microRNA system for Chlamydomonas reinhardtii confirms a key role for heat shock factor 1 in regulating thermotolerance. Curr. Genet. 56, 383-389.

Schroda, M., Vallon, O., Whitelegge, J.P., Beck, C.F., and Wollman, F.A. (2001). The chloroplastic GrpE homolog of Chlamydomonas: two isoforms generated by differential splicing. Plant Cell 13, 2823-2839.

Shao, N., Krieger-Liszkay, A., Schroda, M., and Beck, C.F. (2007). A reporter system for the individual detection of hydrogen peroxide and singlet oxygen: its use for the assay of reactive oxygen species produced in vivo: A system for in vivo detection of individual ROS. Plant J. 50, 475-487.

Singh, R., Parihar, P., Singh, M., Bajguz, A., Kumar, J., Singh, S., Singh, V.P., and Prasad, S.M. (2017). Uncovering Potential Applications of Cyanobacteria and Algal Metabolites in Biology, Agriculture and Medicine: Current Status and Future Prospects. Front. Microbiol. 8.

Smirnoff, N. (2000). Ascorbic acid: metabolism and functions of a multifacetted molecule. Curr. Opin. Plant Biol. 3, 229-235.

Smith, B.M., Morrissey, P.J., Guenther, J.E., Nemson, J.A., Harrison, M.A., Allen, J.F., and Melis, A. (1990). Response of the Photosynthetic Apparatus in Dunaliella salina (Green Algae) to Irradiance Stress. Plant Physiol. 93, 1433-1440.

Sugimoto, I., and Takahashi, Y. (2003). Evidence That the PsbK Polypeptide Is Associated with the Photosystem II Core Antenna Complex CP43. J. Biol. Chem. 278, 45004-45010. 
Suzuki, N., Koussevitzky, S., Mittler, R., and Miller, G. (2012). ROS and redox signalling in the response of plants to abiotic stress. Plant Cell Environ. 35, 259-270.

Szentmihályi, K., Varga, I.S., Gergely, A., Rábai, M., and Then, M. (2015). Antioxidant value and element content in some tinctures used in medication. Acta Biol. Hung. 66, 293-303.

Tamura, N., Inoue, H., and Inoue, Y. (1990). Inactivation of the WaterOxidizing Complex by Exogenous Reductants in PS II Membranes Depleted of Extrinsic Proteins. Plant Cell Physiol.

Tibiletti, T., Auroy, P., Peltier, G., and Caffarri, S. (2016). Chlamydomonas reinhardtii PsbS protein is functional and accumulates rapidly and transiently under high light. Plant Physiol. pp.00572.2016.

Tikkanen, M., Mekala, N.R., and Aro, E.-M. (2014). Photosystem II photoinhibition-repair cycle protects Photosystem I from irreversible damage. BBA Bioenerg. 1837, 210-215.

Tiwari, M., Sharma, D., and Trivedi, P.K. (2014). Artificial microRNA mediated gene silencing in plants: progress and perspectives. Plant Mol. Biol. 86, 118.

Toepel, J., Illmer-Kephalides, M., Jaenicke, S., Straube, J., May, P., Goesmann, A., and Kruse, O. (2013). New insights into Chlamydomonas reinhardtii hydrogen production processes by combined microarray/RNA-seq transcriptomics. Plant Biotechnol. J. 11, 717-733.

Tolleter, D., Ghysels, B., Alric, J., Petroutsos, D., Tolstygina, I., Krawietz, D., Happe, T., Auroy, P., Adriano, J.-M., Beyly, A., et al. (2011). Control of Hydrogen Photoproduction by the Proton Gradient Generated by Cyclic Electron Flow in Chlamydomonas reinhardtii. Plant Cell 23, 2619-2630.

Torzillo, G., Scoma, A., Faraloni, C., and Giannelli, L. (2015). Advances in the biotechnology of hydrogen production with the microalga Chlamydomonas reinhardtii. Crit. Rev. Biotechnol. 35, 485-496.

Tóth, S.Z., Schansker, G., and Strasser, R.J. (2007). A non-invasive assay of the plastoquinone pool redox state based on the OJIP-transient. Photosynth. Res. 93, 193-203. 
Tóth, S.Z., Puthur, J.T., Nagy, V., and Garab, G. (2009). Experimental Evidence for Ascorbate-Dependent Electron Transport in Leaves with Inactive Oxygen-Evolving Complexes. Plant Physiol. 149, 1568-1578.

Tóth, S.Z., Nagy, V., Puthur, J.T., Kovacs, L., and Garab, G. (2011). The Physiological Role of Ascorbate as Photosystem II Electron Donor: Protection against Photoinactivation in Heat-Stressed Leaves. Plant Physiol. 156, 382-392.

Tóth, S.Z., Lőrincz, T., and Szarka, A. (2018). Concentration does matter: The beneficial and potentially harmful effects of ascorbate in humans and plants. Antioxid. Redox Signal.

Truffault, V., Fry, S.C., Stevens, R.G., and Gautier, H. (2017). Ascorbate degradation in tomato leads to accumulation of oxalate, threonate and oxalyl threonate. Plant J. 89, 996-1008.

Ünlü, C., Drop, B., Croce, R., and van Amerongen, H. (2014). State transitions in Chlamydomonas reinhardtii strongly modulate the functional size of photosystem II but not of photosystem I. Proc. Natl. Acad. Sci. 111, 3460-3465.

Urzica, E.I., Adler, L.N., Page, M.D., Linster, C.L., Arbing, M.A., Casero, D., Pellegrini, M., Merchant, S.S., and Clarke, S.G. (2012). Impact of Oxidative Stress on Ascorbate Biosynthesis in Chlamydomonas via Regulation of the VTC2 Gene Encoding a GDP-l-galactose Phosphorylase. J. Biol. Chem. 287, 14234-14245.

Vass, I. (2012). Molecular mechanisms of photodamage in the Photosystem II complex. BBA - Bioenerg. 1817, 209-217.

Venkatesh, J., and Park, S. (2014). Role of L-ascorbate in alleviating abiotic stresses in crop plants. Bot. Stud. 55, 38.

Vidal-Meireles, A., Neupert, J., Zsigmond, L., Rosado-Souza, L., Kovács, L., Nagy, V., Galambos, A., Fernie, A.R., Bock, R., and Tóth, S.Z. (2017). Regulation of ascorbate biosynthesis in green algae has evolved to enable rapid stress-induced response via the VTC2 gene encoding GDP- L -galactose phosphorylase. New Phytol. $214,668-681$.

Virgin, I., Styring, S., and Andersson, B. (1988). Photosystem II disorganization and manganese release after photoinhibition of isolated spinach thylakoid membranes. FEBS Lett. 233, 408-412.

Volgusheva, A., Styring, S., and Mamedov, F. (2013). Increased photosystem II stability promotes $\mathrm{H}_{2}$ production in sulfur-deprived Chlamydomonas reinhardtii. Proc. Natl. Acad. Sci. 110, 7223-7228. 
Vu, C.H.T., Lee, H.-G., Chang, Y.K., and Oh, H.-M. (2018). Axenic cultures for microalgal biotechnology: Establishment, assessment, maintenance, and applications. Biotechnol. Adv. 36, 380-396.

Wheeler, G., Ishikawa, T., Pornsaksit, V., and Smirnoff, N. (2015). Evolution of alternative biosynthetic pathways for vitamin $\mathrm{C}$ following plastid acquisition in photosynthetic eukaryotes. ELife 4.

Wheeler, G.L., Jones, M.A., and Smirnoff, N. (1998). The biosynthetic pathway of vitamin C in higher plants. Nature 393, 365-369.

Wientjes, E., Drop, B., Kouřil, R., Boekema, E.J., and Croce, R. (2013). During State 1 to State 2 Transition in Arabidopsis thaliana, the Photosystem II Supercomplex Gets Phosphorylated but Does Not Disassemble. J. Biol. Chem. 288, 32821-32826.

Wykoff, D.D., Davies, J.P., Melis, A., and Grossman, A.R. (1998). The Regulation of Photosynthetic Electron Transport during Nutrient Deprivation in Chlamydomonas reinhardtii. Plant Physiol. 117, 129-139.

Xiong, L. (2003). Regulation of Abscisic Acid Biosynthesis. PLANT Physiol. $133,29-36$.

Xue, H., Bergner, S.V., Scholz, M., and Hippler, M. (2015). Novel insights into the function of LHCSR3 in Chlamydomonas reinhardtii. Plant Signal. Behav. 10, e1058462.

Yabuta, Y., Mieda, T., Rapolu, M., Nakamura, A., Motoki, T., Maruta, T., Yoshimura, K., Ishikawa, T., and Shigeoka, S. (2007). Light regulation of ascorbate biosynthesis is dependent on the photosynthetic electron transport chain but independent of sugars in Arabidopsis. J. Exp. Bot. 58, 2661-2671.

Yang, Y.-Z., and Tan, B.-C. (2014). A Distal ABA Responsive Element in AtNCED3 Promoter Is Required for Positive Feedback Regulation of ABA Biosynthesis in Arabidopsis. PLoS ONE 9, e87283.

Zechmann, B., Stumpe, M., and Mauch, F. (2011). Immunocytochemical determination of the subcellular distribution of ascorbate in plants. Planta 233, 1-12.

Zhang, L., Happe, T., and Melis, A. (2002). Biochemical and morphological characterization of sulfur-deprived and $\mathrm{H}_{2}$-producing Chlamydomonas reinhardtii (green alga). Planta 214, 552-561. 


\section{List of Publications}

MTMT identification number: 10052738

Nagy V, Vidal-Meireles A, Tengölics R, Rákhely G, Garab G, Kovács L, Tóth SZ (2016) Ascorbate accumulation during sulphur deprivation and its effects on photosystem II activity and $\mathrm{H}_{2}$ production of the green alga Chlamydomonas reinhardtii. Plant Cell Environ 39(7): 1460-1472. doi: 10.1111/pce.12701

Impact factor: 6.173

Kovács L, Vidal-Meireles A, Nagy V, Tóth SZ (2016) Quantitative determination of ascorbate from the green alga Chlamydomonas reinhardtii by HPLC. Bio-protocol 6(24): BioProtoc. 2067. doi: 10.21769/BioProtoc.2067

Impact factor: $N$.A.

Vidal-Meireles A, Neupert J, Zsigmond L, Rosado-Souza L, Kovács L, Nagy V, Galambos A, Fernie AR, Bock R, Tóth SZ (2017) Regulation of ascorbate biosynthesis in green algae has evolved to enable rapid stress-induced response via the VTC2 gene encoding GDP-L-galactose phosphorylase. New Phytologist 214(2): 668-681. doi: 10.1111/nph.14425.

Impact factor: 7.330

Nagy V, Vidal-Meireles A, Podmaniczki A, Szentmihályi K, Rákhely G, Zsigmond L, Kovács L, Tóth SZ (2018) The mechanism of photosystem II inactivation during sulphur deprivation-induced $\mathrm{H}_{2}$ production in Chlamydomonas reinhardtii. The Plant Journal 94(3): 548-561. doi: 10.1111/tpj.13878.

Impact factor: 5.901

Nagy V, Podmaniczki A, Vidal-Meireles A, Tengölics R, Kovács L, Rákhely G, Scoma A, Tóth SZ (2018) Water-splitting-based, sustainable and efficient $\mathrm{H}_{2}$ production in green algae as achieved by substrate limitation of the Calvin-BensonBassham cycle. Biotechnology for Biofuels 11:69. doi: 10.1186/s13068-018-1069-0.

Impact factor: 5.203 
Vidal-Meireles A, Lambrev P, Galambos A, Kovács L, Tóth SZ (in preparation) Ascorbate is not required for zeaxanthin-dependent quenching in the green alga Chlamydomonas reinhardtii. 


\section{Communications at International Conferences}

Vidal-Meireles A, Nagy V, Neupert J, Tengölics R, Rákhely G, Bock R, Garab G, Kovács L, Tóth SZ. The effects of ascorbate on the $\mathrm{O}_{2}$ evolution and $\mathrm{H}_{2}$ production of sulphur-deprived Chlamydomonas reinhardtii cultures. $1^{\text {st }}$ International Solar Fuels Conference, $26^{\text {th }}$ April - $1^{\text {st }}$ May 2015, Uppsala (Sweden) [Poster presentation and Flash talk]

Paneerselvam N, Vidal-Meireles A, Nagy V, Kovács L, Tóth SZ. The PSBO1 protein of photosystem II protects the oxygen-evolving complex from the reducing power of luminal ascorbate. ICAR $2015,5^{\text {th }}-9^{\text {th }}$ July 2015 , Paris (France) [Poster presentation]

Vidal-Meireles A, Neupert J, Nagy V, Kovács L, Zsigmond L, RosadoSouza L, Fernie AR, Bock R, Tóth SZ. Regulation of ascorbate biosynthesis in the green alga Chlamydomonas reinhardtii. ENCAPP 2016, 26 th $^{\text {th }} 29^{\text {th }}$ April 2016, Saint Paul's Bay (Malta) [Poster presentation]

Nagy V, Vidal-Meireles A, Tengölics R, Rákhely G, Garab G, Kovács L, Tóth SZ. Ascorbate accumulation during sulphur deprivation and its effects on photosystem II activity and $\mathrm{H}_{2}$ production of the green alga Chlamydomonas reinhardtii. ENCAPP 2016. 26 $6^{\text {th }}-29^{\text {th }}$ April 2016, Saint Paul's Bay (Malta) [Poster presentation]

Tóth SZ. Regulation of ascorbate biosynthesis in the green alga Chlamydomonas reinhardtii. Photosynthetic electron and proton transport in plants and algae (Satellite meeting of the $17^{\text {th }}$ International Congress on Photosynthesis Research). $4^{\text {th }}-7^{\text {th }}$ August 2016, Arnhem (The Netherlands) [Oral presentation]

Vidal-Meireles A, Neupert J, Zsigmond L, Kovács L, Nagy V, RosadoSouza L, Fernie AR, Bock R, Tóth SZ. Ascorbate biosynthesis and its regulation by $V T C 2$ in the green alga Chlamydomonas reinhardtii. SEB Gothenburg $2017,3^{\text {rd }}-6^{\text {th }}$ July 2017, Gothenburg (Sweden) [Poster presentation] 
Tóth D, Galambos A, Nagy V, Vidal-Meireles A, Podmaniczki A, Kovács L, Molnár A, Tóth SZ. Identification of ascorbate transporters in green algae. First European Congress on Photosynthesis Research, 25th - 28th June 2018, Uppsala (Sweden) [Poster presentation]

Vidal-Meireles A, Galambos A, Kovács L, Tóth SZ. In the green alga Chlamydomonas reinhardtii ascorbate is not required for the induction of non-photochemical quenching. Plant Biology 2018, $14^{\text {th }}-18^{\text {th }}$ July 2018 , Montreal (Canada) [Poster presentation]

Vidal-Meireles A, Galambos A, Kovács L, Tóth SZ. In the green alga Chlamydomonas reinhardtii ascorbate is not required for the induction of non-photochemical quenching. ISPR meeting From Light to Life, $17^{\text {th }}-20^{\text {th }}$ July 2018, Montreal (Canada) [Poster and Oral presentation] 


\section{Awards and fellowships}

- Biological Research Centre of the Hungarian Academy of Sciences PhD scholarship (2013)

- Campus Hungary Conference travel grant (2015)

- Hungarian Academy of Sciences Young Researcher Fellowship (2016)

- Szeged Biology PhD School Best presentation award at the PhD Student Conference (2016)

- Company of Biologists Travel award (2018)

- U.S. Department of Energy Travel award (2018)

- ISPR / Plant Cell \& Environment Best poster by a graduate student at the ISPR Meeting "Photosynthesis: from Light to Life” (2018) 